Florida International University FIU Digital Commons

$11-9-2016$

\title{
The Politics of Democratization: Jean-Bertrand Aristide and the Lavalas Movement in Haiti
}

Dimmy Herard

Florida International University, dhera002@fiu.edu

DOI: $10.25148 /$ etd.FIDC001196

Follow this and additional works at: https://digitalcommons.fiu.edu/etd

Part of the Comparative Politics Commons

\section{Recommended Citation}

Herard, Dimmy, "The Politics of Democratization: Jean-Bertrand Aristide and the Lavalas Movement in Haiti" (2016). FIU Electronic Theses and Dissertations. 3037.

https://digitalcommons.fiu.edu/etd/3037

This work is brought to you for free and open access by the University Graduate School at FIU Digital Commons. It has been accepted for inclusion in FIU Electronic Theses and Dissertations by an authorized administrator of FIU Digital Commons. For more information, please contact dcc@fiu.edu. 


\section{FLORIDA INTERNATIONAL UNIVERSITY}

Miami, Florida

THE POLITICS OF DEMOCRATIZATION: JEAN-BERTRAND ARISTIDE AND

THE LAVALAS MOVEMENT IN HAITI

A dissertation submitted in partial fulfillment of

the requirements for the degree of

DOCTOR OF PHILOSOPHY

in

POLITICAL SCIENCE

by

Dimmy Herard

2016 
To: Dean John F. Stack, Jr.

Steven J. Green School of International and Public Affairs

This dissertation, written by Dimmy Herard, and entitled The Politics of Democratization: Jean-Bertrand Aristide and the Lavalas Movement in Haiti, having been approved in respect to style and intellectual content, is referred to you for judgment.

We have read this thesis and recommend that it be approved.

John F. Stack, Jr.

Chantalle F. Verna

Clement Fatovic

Ronald W. Cox, Major Professor

Date of Defense: November 9, 2016

The dissertation of Dimmy Herard is approved.

Dean John F. Stack, Jr.

Steven J. Green School of International and Public Affairs

Andrés G. Gil

Vice President for Research and Economic Development and Dean of the University Graduate School

Florida International University, 2016 
(C) Copyright 2016 by Dimmy Herard

All rights reserved. 


\section{ACKNOWLEDGMENTS}

I would like to, first and foremost, dedicate this dissertation to my mother, Caridad Superville Pierre, whose life story of strength and resolve in the face of hardship has taught me the value of hard work and persistence, without which I would not be the person I am today. I also wish to express all my love and gratitude to my partner in life, Hadassah St. Hubert, who has been a source of much hope during a rather turbulent time. It is her words of consistent encouragement and support that have inspired me to keep pressing forward with confidence and conviction.

Sincerest thanks to the members of my dissertation committee: Dr. Ronald W. Cox, Dr. John F. Stack, Dr. Chantalle F. Verna, and Dr. Clement Fatovic, whose guidance and mentorship have been invaluable to my development as a student, as scholar, and as an educator. I could never thank them enough for their collective support throughout this entire process. I particularly owe an enormous debt of gratitude to my dissertation advisor, Dr. Cox, whose belief in me from the very beginning, to the very end, is a testament to his undying dedication to the students under his tutelage. Similarly, his advocacy for poor and working class people against the abuses of the powerful has been a central inspiration for this work.

And lastly, I am grateful to the numerous individuals and institutions that over the course of many years have spurred me along this path. I want to thank Florida International University's Department of Politics and International Relations for granting me the Graduate Teaching Assistantship. My experience as a student in this department has been invaluable to my personal and professional growth, and will not be forgotten. I also offer a special note of appreciation to the department's staff, past and present, 
without whose help I would not have been able to find my way. I would like to thank the School of International and Public Affairs (SIPA) and the Morris and Anita Broad family for supporting my archival research at the New York Public Library's Schomburg Center for Research. I am eternally grateful for the many opportunities to grow academically and professionally that were offered to me over the years working with the Extreme Events Institute's Disaster Risk Reduction Program. I offer a warm thanks to Dr. Richard S. Olson, Dr. Juan Pablo Sarmiento, Dr. Garbiela Hoberman, and Meenakshi Jerath, whose mentorship and professional guidance will not be forgotten. I wish to thank the Kimberly Green Latin American and Caribbean Center, Dr. Frank Mora, Lies1 Picard, and staff. I am appreciative of the numerous opportunities I have had to work with the Digital Library of the Caribbean (dLOC), the Green Family Foundation (GFF), FIU Libraries, Mireille Louis Charles, Brooke Wooldridge, Rose Nicholson, and Adam Silvia. I would also like to thank all of my graduate student peers who have shared in both times of great difficulty, but also times of great progress. Lastly, an affectionate thank you to all of my family and friends, too numerous to name, who provided me with a core of emotional support that has carried me here to this point. This dissertation is very much a product of all the people who have supported me over the years. 


\title{
ABSTRACT OF DISSERTATION \\ THE POLITICS OF DEMOCRATIZATION: JEAN-BERTRAND ARISTIDE AND \\ THE LAVALAS MOVEMENT IN HAITI
}

\author{
by \\ Dimmy Herard \\ Florida International University, 2016 \\ Miami, Florida \\ Professor Ronald W. Cox, Major Professor
}

As the 29-year Duvalier dictatorship ended in 1986, the emergence of Mouvement Lavalas out of the grassroots organizations of Haiti's poor majority, and election of charismatic priest Jean-Bertrand Aristide in 1990, challenged efforts by Haitian political parties and the U.S. foreign policy establishment to contain the parameters of Haiti's democratic transition. This dissertation examines the politics of Lavalas to determine whether it held a particular conception of democracy that explains the movement's antagonistic relationship with the political parties and U.S. democracy promoters.

Using the qualitative methodology of process-tracing outlined in the works of Paul F. Steinberg (2004) and Tulia G. Falleti (2006), this study analyzes primary and secondary sources associated with Aristide and the grassroots organizations across the period of contested democratization from 1986 to 1991, with emphasis on four critical junctures: 1) the rule of the Conseil National du Gouvernement; 2) the government of Leslie Manigat; 3) the military regimes of Henri Namphy and Prosper Avril; and 4) Aristide's 8 months in power before being overthrown on September 29, 1991. 
This study concludes that there were systematic differences in how Lavalas pursued democracy in Haiti, as contrasted to the political parties and U.S. foreign policymakers. Evidence indicates that while Lavalas placed emphasis on popular mobilization to challenge Haiti's legacy of authoritarianism, the political parties and U.S. democracy promoters emphasized processes of negotiation and compromise with Haiti's antidemocratic forces. Lavalas was rooted in the long historic struggle of the country's poor masses to, not simply establish procedural democracy, what noted political scientist Robert Dahl calls polyarchy, but to expand the parameters of politics to guarantee the right of all Haitians to participate directly in the process of governing, in order to share more equitably in the distribution of national resources, in what critical scholar William I. Robinson calls "popular democracy." 
TABLE OF CONTENTS

CHAPTER

PAGE

I ......

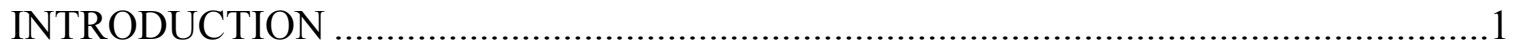

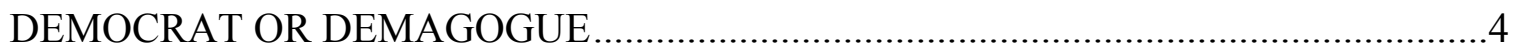

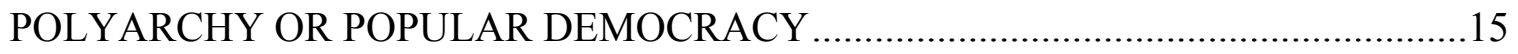

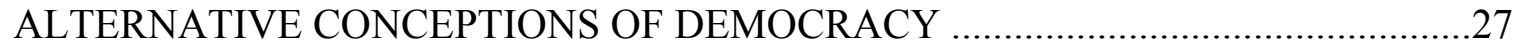

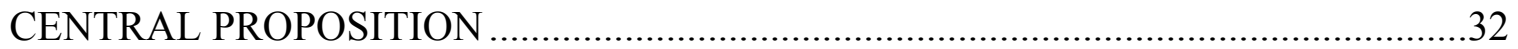

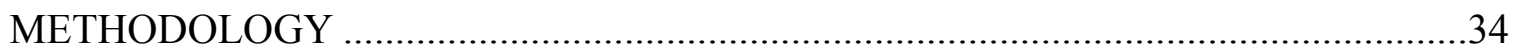

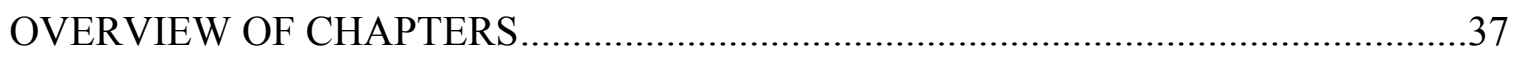

II .

DISCIPLINING HAITI'S LABORING MASSES ………......................................

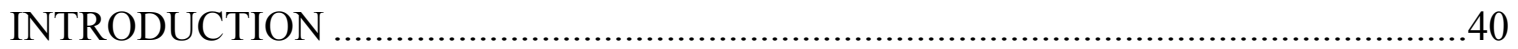

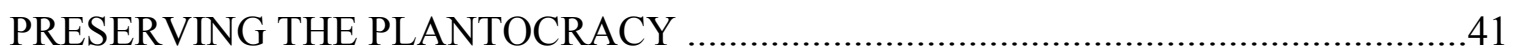

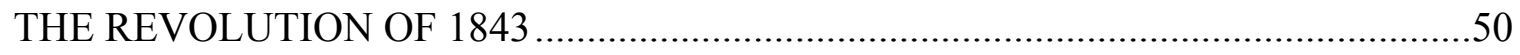

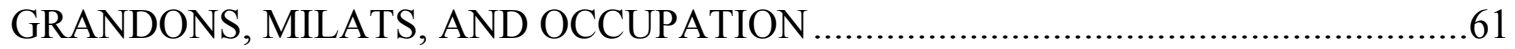

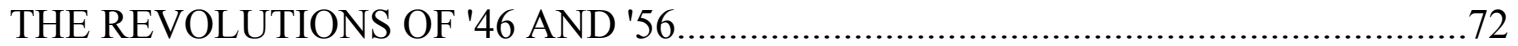

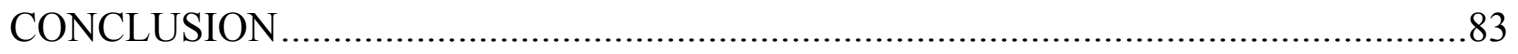

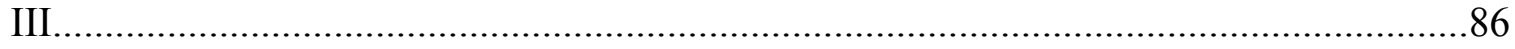

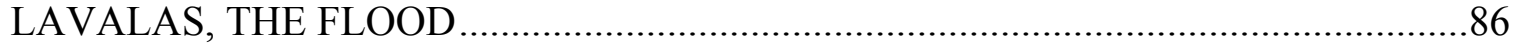

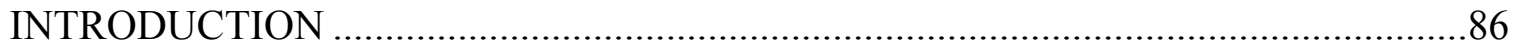

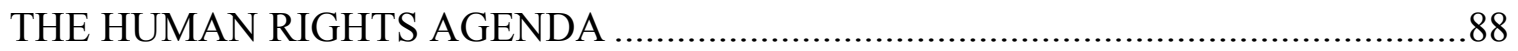

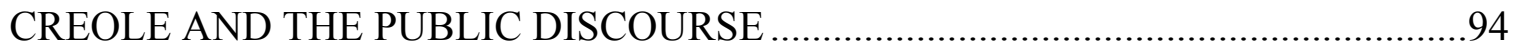

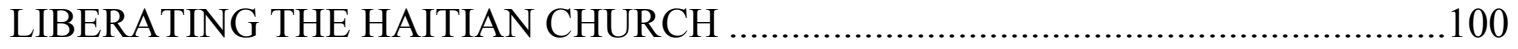

REDEFINING HUMAN RIGHTS, CONSTRAINING DEMOCRACY ………............110

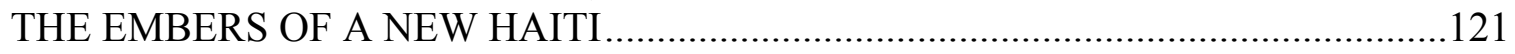

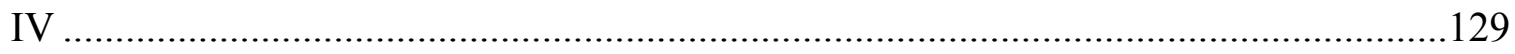

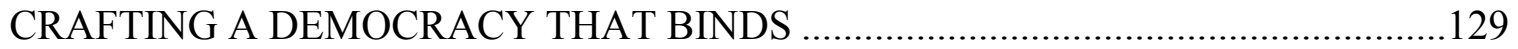

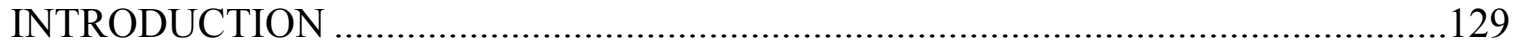

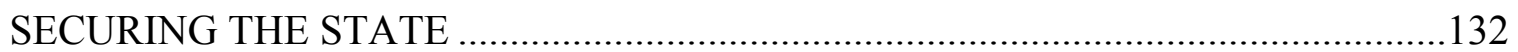

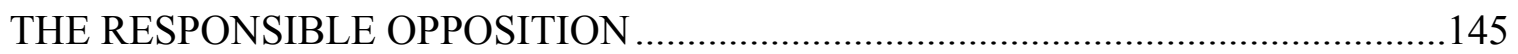

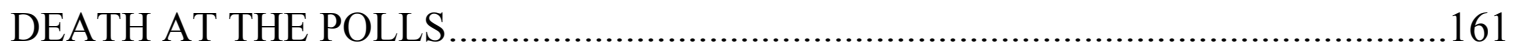

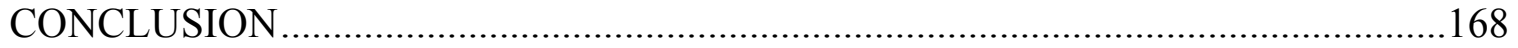

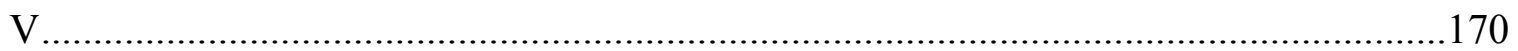

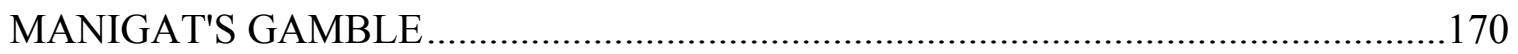

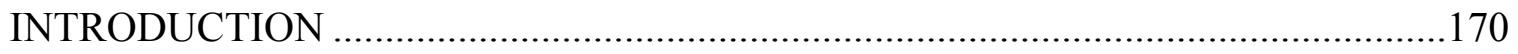

FINDING A MINIMAL CONSENSUS ……………...........................................170

viii 


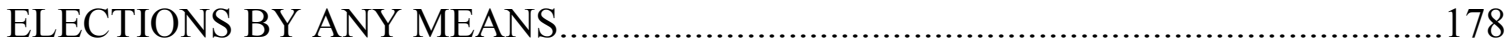

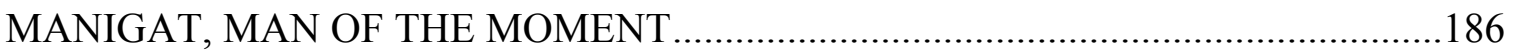

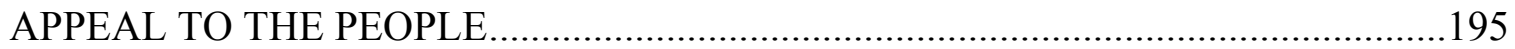

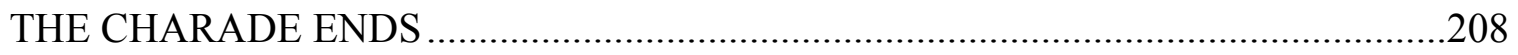

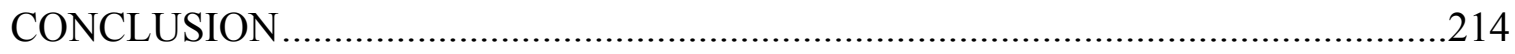

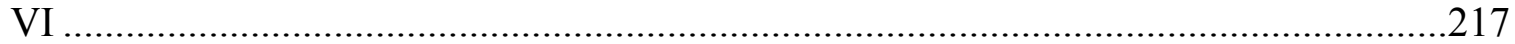

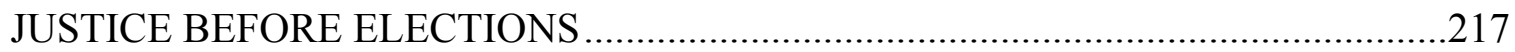

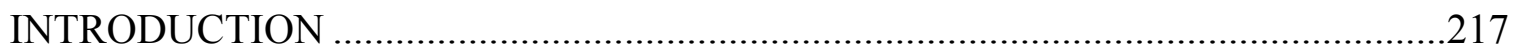

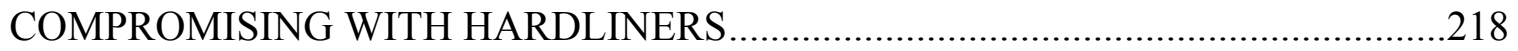

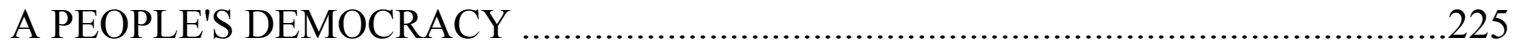

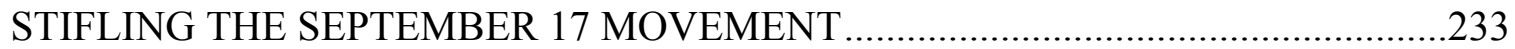

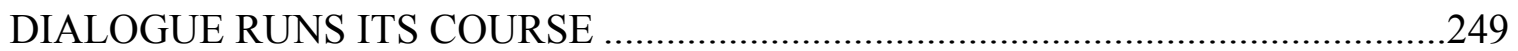

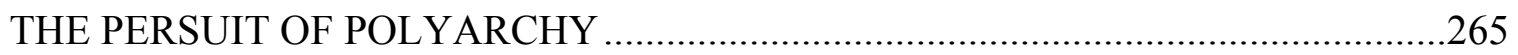

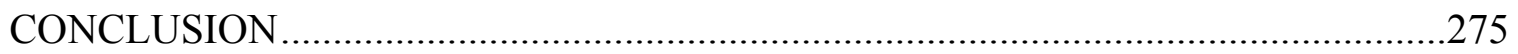

VII

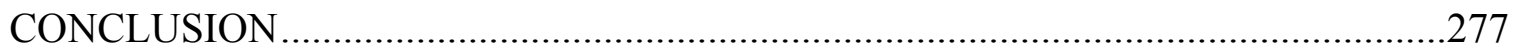

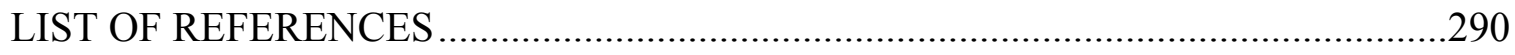

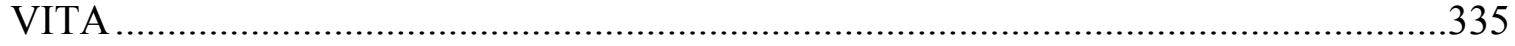




\section{CHAPTER I.}

\section{INTRODUCTION}

On February $7^{\text {th }} 1986$, Haiti's dictator, Jean-Claude Duvalier, was forced to release the reins of power, ending 29 years of Duvalierisme, and leaving behind one of the most sordid legacies of any despot in the region's history. The Duvalier dynasty, begun by Francois Duvalier in 1957, presided over the state-sponsored killing of anywhere between 30,000 and 60,000 people, the embezzlement of nearly 80 percent of international aid to the country, approximately $\$ 10$ million more from the national treasury yearly, and Haiti's traumatic descent towards abject poverty along every conceivable statistical category. ${ }^{1}$ After 5 years struggling to wrest power from an ever more repressive provisional Conseil National du Gouvernement (CNG), a historically disenfranchised people triumphantly ushered in what many believe to be the first truly democratic government of $A y i t i^{2}$ with the inauguration of charismatic priest JeanBertrand Aristide on February 7, 1991.

But from the very beginning a number of questions emerged regarding the democratic orientation of Aristide, and the social movement that ushered him into power, Lavalas. According to Samuel Huntington, the greatest barrier to the consolidation of democracy is often the lack of commitment to democratic principles by those who seek to displace autocrats in the name of democracy. "When they are out of power, political leaders have good reason to advocate democracy. The test of their democratic

\footnotetext{
${ }^{1}$ James Ferguson, Papa Doc, Baby Doc: Haiti and the Duvaliers (Oxford: B. Blackwell, 1988).

${ }^{2}$ Ayiti is the Haitian Creole spelling for Haiti. Ayiti was the original indigenous Taíno or Amerindian name for the island meaning land of high mountains.
} 
commitment comes once they are in office." ${ }^{3}$ Was Aristide the radical leftist demagogue that some clamored he was; ${ }^{4}$ the quintessential Ayatollah Khomeini slash Fidel Castro of Haiti? ${ }^{5}$ Was Lavalas simply a manifestation of the unsorted poor riled up into an uncontrollable frenzy towards class hatred, unquestioningly following the instructions of their anointed messiah? Or did Mouvement Lavalas represent the emergence of a democratic grassroots movement like none ever seen before in Haiti's history?

The central intention of this dissertation is to examine the politics of the Lavalas movement and its presumed leader, Jean-Bertrand Aristide, to determine whether or not the movement had a clearly outlined agenda for establishing a particular vision of democracy in Haiti. This process will consist of an in-depth examination of the type of society Aristide and Lavalas sought to build in Haiti; how the movement's political visions coincided and contrasted with various competing theories and ideologies of democratization; and how its politics shifted and fractured over time in response to internal tensions and contradictions, as well as external political and economic pressures.

This research is significant because it delves into areas of Haitian politics previously ignored. Much of the literature on the democratization process within Haiti following Baby Doc's fall and the election of Aristide focuses almost exclusively on U.S. foreign policy towards Haiti, and Aristide's actions in response, thus ignoring much of the political dynamics that were occurring within Haiti amongst the various segments of the emergent democratic sector. While much has been said about Aristide's supposed

\footnotetext{
${ }^{3}$ Samuel Huntington, "Democracy's Third Wave," Journal of Democracy 2, no. 2 (Spring 1991): 22.

${ }^{4}$ Philippe R. Girard, Clinton in Haiti (New York: Palgrave Macmillan, 2004), 23.

${ }^{5}$ Andrew S. Levin, "Civil Society and Democratization in Haiti," Emory International Law Review 9, no. 2 (1995): 389-457.
} 
deviations from democratic norms and principles, few of these scholars have systematically engaged with the concept of democracy itself, nor with the particular conceptions of democracy held by Aristide and Mouvement Lavalas. These studies fail to investigate whether or not an alternative conception of democracy was coming to the fore with the emergence of the Lavalas movement. Part of this failure is related to their treatment of Aristide and Lavalas as synonymous, rather than delving into the particularities of Lavalas as a separate and distinct phenomenon from Aristide. Their topdown analysis of democratization, presumably a bottom-up process, ignores the agency of the Haitian demos. Most of the literature pertaining to this period in Haitian history simply does not give in-depth attention to the broader civil society activity that emerged during the last years of Baby Doc's regime, expanding after his fall, and presumably evolving into what is Lavalas and the movement for democracy in Haiti.

This research will address fundamental questions pertaining to the process of democratization and its relationship to broader political, economic, and social processes. It will also seek to understand the role of social movements in the transition to democracy, and whether or not they are capable of forging democracy in a poor developing country with a robust authoritarian legacy.

The remainder of this chapter is divided into four parts. In the first I address the various assessments of Aristide's adherence to democratic norms and values throughout his involvement in Haitian politics. The second section addresses the primary theoretical frameworks through which the concept of democracy has been understood in Western intellectual thought, particularly in the age of democracy. In the third part of this chapter I present various causal propositions as to why Aristide and Lavalas failed to consolidate 
democratic gains in Haiti. And in the final section, I outline the methodology that will be used to test each proposition, the primary case studies to be analyzed, and sources.

\section{DEMOCRAT OR DEMAGOGUE}

From the very beginning of Jean-Bertrand Aristide's foray into Haitian politics, there have been competing interpretations of his commitment to democracy, and thus naturally conflicting interpretations of his role as the presumed leader of Lavalas and as the President of Haiti. For many, Aristide's election held out the possibility of him becoming "either the father of Haitian democracy or just one more of its many betrayers."

From 1987 to 1991 Aristide was viewed as embodying the aspirations of the Haitian masses; their longing for a just and egalitarian democracy. ${ }^{7}$ Elected in 1990 with nearly 70 percent of the popular vote, those who had suffered silently for so long under the yoke of economic deprivation and political repression believed that finally they would control the country's instruments of power and provide a central voice in the decisions that impacted their lives. ${ }^{8}$ In the priest-turned-politician, whom some had come to call Haiti's Mandela, ${ }^{9}$ the poor saw "their most unwavering ally in gaining a greater voice in national affairs. ${ }^{10}$ For these wretched of the Earth, "Father Aristide alone...could bring

\footnotetext{
6 "Haiti's Choice, and Father Aristide's," New York Times, December 18, 1990.

${ }^{7}$ Alex Dupuy, The Propet and Power (Lanham: Rowman \& Littlefield Publishers, 2007), 20.

${ }^{8}$ Ibid., 21.

${ }^{9}$ Howard W. French, "A Priest to the Very Poor at the Pinnacle in Haiti: Jean-Bertrand Aristide," New York Times, December 19, 1990.

${ }^{10}$ Howard W. French, "Poor in Haiti Back Election of Ex-Priest," New York Times, December 15, 1990.
} 
an end to violent repression and provide dignity." ${ }^{, 11}$ According to Paul Farmer, Aristide's electoral victory was not his own, but rather a victory for the Haitian peasantry. “They'd braved intimidation, even massacres, to make it happen and to vote. It seemed as if, at last, after centuries of misery, of slavery and subsequent misrule and foreign interference, the people of Haiti had claimed their country." ${ }^{22}$ Finally, government would be organized around the principles of justice, transparency, and most importantly, participation. ${ }^{13}$

Despite the hopes and aspirations of Haiti's poor and previously disenfranchised, many others had misgivings about the man affectionately called Titid. Haiti's small educated middle class, who spent decades hoping for democratic change, were particularly concerned with how Aristide conceived the presidency. Now that he was out front, they felt little reassured. ${ }^{14}$ Many were profoundly doubtful that Aristide could bring peace and stability to Haiti. ${ }^{15}$

For others, there was no equivocation as to his intentions. One of the charges leveled against Aristide was that he promoted class warfare and mob rule. That he held a worldview that instinctively saw the wealthy as bad and the poor as noble. ${ }^{16}$ That he was establishing a rhetorical undertone that was making violence, particularly of the class

\footnotetext{
${ }^{11}$ French, "A Priest to the Very Poor," 1990.

${ }^{12}$ Tracy Kidder, Mountains Beyond Mountains (New York: Random House, 2003), 109.

${ }^{13}$ Paul Farmer, The Uses of Haiti (Monroe, Me.: Common Courage Press, 1994), 156.

${ }^{14}$ Howard W. French, "Front-Running Priest a Shock to Haiti,” New York Times, December 13, 1990.

${ }^{15}$ Howard W. French, "Poor in Haiti Back Election of Ex-Priest," New York Times, December 15, 1990.

${ }^{16}$ French, “A Priest to the Very Poor,” 1990.
} 
warfare variant, impossible to contain. ${ }^{17}$ His sermons were said to have been laced with calls to revolution. ${ }^{18}$ While speaking of repression, misery, and the short-sightedness of the rich, he also spoke of guns and war. ${ }^{19}$ "Vive la guerre!" he clamored before his congregations, "so that we will all have bread. Vive la guerre! So that we will all have houses. Vive la guerre! So that we will all have land. ${ }^{20}$ According to Alex Dupuy, one of Aristide's favorite parables was that of Haiti's privileged few sitting at a dinner table eating steak and pâté while the rest of the country's destitute majority cowered hungrily under the table, in hopes of perhaps tasting the crumbs that fell from the plates of the wealthy. Inevitably, Aristide proclaimed, this huddled mass would overturn this table of privilege and take what was their rightful share. ${ }^{21}$ In 1988 Aristide the priest would be expelled from his Salesian Order for his supposed 'incitement to hatred and violence,' and 'glorifying of class struggle. ${ }^{, 22}$ After his election, Archbishop François-Wolff Ligondé attacked “Aristide as a 'socio-bolshevik,' and wondered whether or not 1991 would mean the 'beginning of a dictatorship.",23

\footnotetext{
${ }^{17}$ Howard W. French, "Haiti’s Victors Working to Soothe Fears," New York Times, January 11, 1991.

${ }^{18}$ Joseph B. Treaster, “A Haitian Priest is Ousted by Order: Roman Catholic Group Expels Cleric Critical of Bishops' Panel and Government," New York Times, December 18, 1988.

${ }^{19}$ Mark D. Danner, “The Struggle for a Democratic Haiti,” New York Times, June 21, 1987.

${ }^{20}$ Ibid., 1987.

${ }^{21}$ Alex Dupuy, Haiti in the New World Order: The Limits of the Democratic Revolution (Boulder, Colorodo: Westview Press, 1997), 75-76.

${ }^{22}$ Mark Danner, "The Fall of the Prophet," New York Review of Books, December 2, 1993.

${ }^{23}$ Farmer, The Uses of Haiti, 156.
} 
In the U.S. media and government circles, a narrative emerged portraying Aristide as an archetypical anti-American leftist demagogue; ${ }^{24}$ a psychotic manic-depressive ${ }^{25}$ who used mob violence to intimidate and subdue all opposition, whether Duvalierist, democratically elected parliamentarian, or media critic. A starting point for many was his casual confession that the slaughter of Duvalier's supporters following the regime's demise left him marveling at the people's justice as they carried out what he proclaimed to be God's work. ${ }^{26}$ Many felt that Aristide tacitly supported the use of Pére Lebrun against his opponents, a form of lynching whereby a tire is placed around the neck of a targeted person, filled with gasoline, and set afire. ${ }^{27}$ In fact, they pointed to a number of radio addresses following these incidents, where alongside references to the 'hideousness' of the destruction, Aristide proclaimed the legitimacy of the people's will to catch powerful supporters of Duvalierism so that they would not destroy them tomorrow. ${ }^{28}$ Others state that Aristide's lust for power at all costs was evident when he vehemently rejected calls to persuade his followers to abstain from violence should he fail to win the 1990 elections as a result of the potential widespread fraud that had characterized previous Haitian elections. $^{29}$

\footnotetext{
${ }^{24}$ Girard, Clinton in Haiti, 23.

${ }^{25}$ Ralph Pezzullo, Plunging into Haiti: Clinton, Aristide, and the Defeat of Diplomacy (Jackson: University Press of Mississippi, 2006), 38.

${ }^{26}$ Girard, Clinton in Haiti, 33.

${ }^{27}$ Howard W. French, "Troops, Storming Palace, Capture Plotters and Free President," New York Times, January 8, 1991. Ralph Pezzullo, Plunging into Haiti, 138.

${ }^{28}$ Robert Debs Heinl, Nancy Gordon Heinl, and Michael Heinl, Written in Blood: The Story of the Haitian People, 1492-1995 (Lanham: University Press of America, 1996), 734.

${ }^{29}$ Girard, Clinton in Haiti, 88.
} 
For observers like New York Times foreign correspondent Howard French, the 1990 presidential election was nothing more than a "conflict between two irreconcilable forces," intimating that neither was particularly more virtuous than the other. "The Duvalierists have never abandoned their dream of returning to power and have recruited their most audacious leader...to accomplish it. 'The partisans of confrontation with the Duvalierists have responded in kind by choosing Father Aristide. The political debate is now on the path of radicalization and confrontation.", 30 Many reporting on the events in Haiti feared that the "violent confrontations between Duvalierists and Aristide's supporters" ${ }^{31}$ were simply another iteration of Haiti’s long legacy of zero-sum politics. According to the head of the Haitian Center for Human Rights, Jean-Jacques Honorat, Aristide was "inciting people to riot," and producing an environment with "all the ingredients for a new fascism." He declared that human rights violations were as severe under Aristide as they were during the Duvalier dictatorships. ${ }^{32}$

Others pointed to Aristide and Lavalas' utter disdain and rejection for the legal and institutional trappings of a democratic society. Often Aristide would respond to criticisms of his supporters' actions by stating that the people were the law, and thus whatever they did was constitutional. ${ }^{33}$ Aristide and Lavalas were also seen as dismissive, if not openly hostile, to the idea of the Haitian media's role in holding the

\footnotetext{
${ }^{30}$ Howard W. French, "A Duvalier Ally and a Foe Seek Election in Haiti, Raising Fears of Violence," New York Times, November 5, 1990.

31 “Top Duvalierist Among 10 Barred from Seeking Haiti's Presidency," New York Times, November 7 , 1990.

${ }^{32}$ Farmer, The Uses of Haiti, 156.

${ }^{33}$ Girard, Clinton in Haiti, 34.
} 
movement and his government accountable. Haiti's media held particularly mixed feelings regarding the movement and its leader. On the one hand was their enthusiasm for Haiti's first truly democratic election. On the other were misgivings concerning the media's right to criticize Aristide's actions in the face of potential retribution from what they saw as his fanatical supporters. ${ }^{34}$

Lavalas' supposed contempt for accountability is often credited to the movement's messianic sense of Aristide's role in Haitian history. His candidacy was characterized by a certain mysticism. "There is nothing prosaic, planned or typically electoral about 37-year-old Aristide's last-minute bid to be president. Instead, steeped in the emotion of a religious revival and the language of the apocalypse, his is raw, cathartic populism with a messianic message..35 According to Dupuy (2007), Lavalas was nothing more than a cult-of-personality with little to no mechanisms of accountability or real adherence to democratic processes. ${ }^{36}$ In his The Prophet and Power, Dupuy outlines what he sees as two contradictory tendencies that characterized the ex-president's political ideology. He argues that while Aristide's theologically inspired political philosophy allowed him to embody the aspirations of Haiti's poor and destitute majority for equal and dignified participation in the country's political and economic life, it also produced a charismatic form of leadership that rejected the rule of law and constitutionalism as legitimate limitations on his power. ${ }^{37}$

\footnotetext{
${ }^{34}$ Howard W. French, "Haiti’s Press Holds Its Critical Tongue," New York Times, January 29, 1991.

${ }^{35}$ Sontag, "Haitian Masses Find a 'Prophet,"” 1990.

${ }^{36}$ Dupuy, The Prophet and the Power, xiii.

${ }^{37}$ Ibid., xiii.
} 
For Dupuy and others, Aristide's support for popular justice rather than the rule of law emanates from his belief that the struggle of Lavalas against Duvalierism was one of Good against Evil, thus leaving little room for moderation and reconciliation. During the dechoukaj, as "delirious crowds methodically stripped bare the great houses of the dictator's cronies, and mobs beheaded, stoned or burned alive the more murderous of his denim-clad Tontons Macoutes militia...[Aristide] 'stood and marveled at the justice of the people'... 'These Macoutes, they were the devil incarnate. The people were doing God's work,",38 he declared.

His critics contend that it is this notion of moral struggle that shapes his view of constitutional checks and balances, and limited government in general. "President Aristide stated in his autobiography that he envisioned a 'direct' democracy rather than a representative one," 39 which led him to eschew the left-of-center coalition that helped him come to power and to ignore the give-and-take of parliamentary politics. Such petty politics were viewed as a negation of the power that the people had bequeathed to him, their chosen representative. "He stood above all other political actors or organizations, who lacked this symbiotic relationship with the masses...the 'prophetic' people had propelled him onto the historical stage... only he and his Lavalas movement could bring about the transformations that the people demanded." ${ }^{41}$ As one of the former priest's

\footnotetext{
${ }^{38}$ Mark D. Danner, “The Struggle for a Democratic Haiti,” New York Times June 21, 1987.

${ }^{39}$ Pezzullo, Plunging into Haiti, 141.

${ }^{40}$ Ibid., 142.

${ }^{41}$ Dupuy, Haiti in the New World Order, 86.
} 
supporters exclaimed, "he doesn't need any program. Aristide is a symbol.",42 Under this logic, institutions were viewed as illegitimate, particularly if they were deemed as obstructing the moral work that was to be carried out by Lavalas and its chosen representative, Aristide.

As Aristide gained prominence as Haiti’s first democratically elected president, Howard French wondered whether or not he might not also become a new and strikingly different sort of Haitian 'Big Man'? ${ }^{43}$ For Robert Fatton, Aristide's messiah complex was no different from that of the country's previous rulers. "The overwhelming majority of Haitian rulers, including Toussaint Louverture, Jean-Jacques Dessalines, Francois Duvalier...have claimed that their own person embodied the popular will and that God had sanctified their mission." ${ }^{44}$ Each believed that they had a special relationship with the people; a relationship which was to be privileged over the mundane practices of formal democracy. "The fusion of mysticism, martyrdom, and anti-macoutism added a messianic character to Aristide's leadership and immediately won him the devotion of a population that — crushed by the abject exploitation of the dominant classes and the violence of the dictatorships and steeped in its own religious mysticism - was ready to accept a savior. ${ }^{, 45}$ It is believed that Aristide exploited this vulnerability in the Haitian masses for authoritarian ends.

\footnotetext{
${ }^{42}$ Bohning, “Cleric Takes Center Stage as Vote Nears," New York Times, 1990.

${ }^{43}$ Howard W. French, "Voodoo Politics: The Rainy Season Haiti Since Duvalier. By Amy Wilents," June 25,1989 .

${ }^{44}$ Robert Fatton, The Roots of Haitian Despotism (Boulder: Lynne Rienner Publishers, 2007), 13.

${ }^{45}$ Dupuy, Haiti in the New World Order, 72-73.
} 
It is for these reasons that many in Haiti, in the U.S., and in the international community, view the eventual September $30^{\text {th }}, 1991$ removal of Aristide from power by the military as "rife with murky complexities." Though Aristide became the President of Haiti through free and fair elections which he won handily, and continued to maintain the support of Haiti's poor majority, these same persons argued that Haitian democracy was not contingent upon the return of Aristide to power. According to Mr. Widmair of Radio Métropole, "you cannot justify the coup, but there is much to blame Aristide for. All of the sectors of society wanted to participate in the democracy, but for seven months they were bombarded with nothing but threats. ${ }^{46}$ Upon removing Aristide from power, General Cedras and members of the military argued that the coup was necessary to ensure respect for the constitutional order, to guarantee democratic liberty, and to prevent the pillaging and lynching that they accused Aristide of encouraging. ${ }^{47}$ North Carolina Senator Jesse Helms declared the ousted President a demonstrable killer, who "made fiery speeches exhorting his followers to use the necklace method, as it is called, to destroy his enemies in agony." ${ }^{, 8}$ Though initially showing unequivocal support for the restoration of Haiti's first democratically elected president, U.S. officials eventually shifted their position, conceding that "Father Aristide's condoning and even encouragement of vigilante justice by mobs of his supporters in the streets has jeopardized his moral authority and popularity." ${ }^{, 49}$ The coup, they declared, had been a

\footnotetext{
${ }^{46}$ Howard W. French, "Envoys Arrive in Haiti to Seek an End to Coup," New York Times, October 5, 1991.

47 "Haiti's Military Assumes Power After Troops Arrest the President," New York Times, October 1, 1991.

${ }^{48}$ Danner, "The Fall of the Prophet," 1993.

${ }^{49}$ Clifford Krauss, "In Policy Shift, U.S. Criticizes Haitian on Rights Abuses," New York Times, October 7, 1991.
} 
reaction to "flagrant abuses of power." ${ }^{50}$ As a precondition to supporting his return to Haiti, the Clinton administration called on Aristide to renounce his advocacy of violence against opponents, and to declare his support for the constitution and the rule of law.

With Aristide's return to Haiti, some observers argue that what had been merely subtle tendencies in his first few months in power became much more overt. Rather than the public exhortations supporting mob lynchings that characterized his first administration, it is claimed that Aristide had turned to a silent campaign of assassinations against those associated with the coup and the subsequent military dictatorship, as well as former political allies no longer deemed loyal. Alongside this campaign of elimination, Aristide was said to have been arming young men in the slums of the capital, known as chimere, to intimidate opponents of the regime. Aristide's demobilization of the Haitian Army and supposed efforts to subsequently control the process of building Haiti's new police force were viewed as part of a strategy to monopolize the capacity for violence in Haiti as Duvalier had once done.

For Fatton, the clientelism of Lavalas became quite apparent with Aristide's return to Haiti through the United States orchestrated Operation Uphold Democracy in 1994. Others argue that Aristide's populism was but a mask; that despite his rhetoric, he was never fully with the people. Instead, the former priest is portrayed as nothing more than a representative of the narrow class interests of the weaker factions of the bourgeoisie, particularly the petite bourgeoisie, that were excluded from Duvalier's inner circle. It was mostly members of this class that made up the leadership of the various

\footnotetext{
${ }^{50}$ Thomas L. Friedman, "The O.A.S. Agrees to Isolate Chiefs of Haitian Junta," New York Times, October $3,1991$.
} 
Lavalas organizations. ${ }^{51}$ Dupuy describes Aristide as an anarcho-populist, who, while claiming to be subject to the dictates of the masses, actually remained broadly popular by securing the ongoing support of their leaders using traditional clientelism. ${ }^{52}$ Aristide was able to "solidify support from his mass base by giving its leaders public-sector jobs whether or not they were qualified for them." ${ }^{53}$ Once back in Haiti, Fatton contends that Aristide's Lavalas regime began to exhibit the patterns of nepotism and clientelism that have characterized traditional Haitian politics more overtly. Lavalas had transformed from being a broad-based movement focused on social justice for the poor and destitute of Haiti into a vehicle for the enrichment of a new class of grands mangeurs (big eaters) ${ }^{54}$ For critics, corruption and narco-trafficking became the leitmotif of the returned Lavalasians. ${ }^{55}$ With such a transformation, power was not to be shared. It was "the springboard to material well-being and class climbing for the relatively marginalized but educated petite bourgeoisie from whose ranks come most Haitian politicians," ${ }^{56}$ including those within Lavalas.

Beyond the corruption, the cronyism, and the elimination of political enemies, perhaps the most damning charge against Aristide was the view that upon his return to power, he fundamentally betrayed the aspirations that once imbued Lavalas with popular

\footnotetext{
${ }^{51}$ Dupuy, The Prophet and Power, 96.

${ }^{52}$ Ibid., 96.

${ }^{53}$ Ibid., 126.

${ }^{54}$ Robert Fatton, Haiti's Predatory Republic: The Unending Transition to Democracy (Boulder, Colorodo: Lynne Rienner Publishers, 2002), 10.

${ }^{55}$ Fatton, The Roots of Haitian Despotism, 210.

${ }^{56}$ Fatton, Haiti's Predatory Republic, 14.
} 
purpose. In order to gain U.S. support for his return, Aristide "signed on to a neoliberal structural adjustment program identical to that implemented by Baby Doc in the 1970s and 1980s...Aristide betrayed the peasants through trade liberalization, canceled equity projects for the poor and sweatshop workers, and instead opened Haiti for business."${ }^{, 57}$ Fatton argues that Aristide had become an advocate for the dictates of structural adjustment that he once vociferously denounced. He now wooed U.S. investors with promises of reduced phone, electricity, customs fees, and tariffs. ${ }^{58}$ Later he would champion the displacement of thousands of peasants in the name of export-processing, continuing the 'American Plan' that had become all the rage under Baby Doc.

\section{POLYARCHY OR POPULAR DEMOCRACY}

While the accusations leveled against Aristide and the Lavalas movement may or may not be valid, it is my contention that the primary cause for the failure to consolidate democratic gains in Haiti had as much to do with the dissonance between the particular conceptions of democracy that informed the politics of Aristide and Lavalas and the hegemonic notions of democracy that have been aggressively propagated by the United States and its Western allies since the end of the Cold War.

Though many presume that democracy is a rather straightforward thing, the truth is that it is a highly contested concept mired in a multitude of ideological and political struggles, competing visions, definitions, and interpretations. But, if one looked to the

\footnotetext{
${ }^{57}$ Ashley Smith, "The New Occupation of Haiti: Aristide's Rise and Fall," International Socialist Review 35, (May-June 2004), http://isreview.org/issues/35/aristide.shtml.

${ }^{58}$ Jonathan P. Decker, "US Investors Hesitate to Reopen Former Business Links With Haiti," Christian Science Monitor, December 23, 1994.
} 
popular discourse, this would not be readily apparent. According to critical scholar William Robinson, one particular perspective of democracy has become internationally hegemonic amongst intellectuals, the media, and policy-makers: polyarchy. ${ }^{59}$ But, before outlining what polyarchy is, Robinson believes that laying out a historical understanding of democracy is essential to seeing how polyarchy is a tragic distortion of the concept.

Traditionally, the term democracy, meaning 'rule of the people,' described the form of government that existed in the Greek city-states of antiquity. "Rule of the people' was synonymous with popular democracy, or government based on the broad distribution of political power and the participation of as many as possible in the making of government policy, directly or through elected representatives. According to Robinson, popular participation should function as a means to undo unjust social and economic realities. He argues that broad participation without corresponding movement towards a more egalitarian socioeconomic order is pointless, and does not meet the standards of democracy as the term is historically understood. The process of equal participation should naturally lead to increased wellbeing for the majority. ${ }^{60}$ Flowing from this understanding of popular democracy is the concept of social democracy, which interprets fundamental human rights to include economic and social rights, with the intent of democratic processes being to provide a minimal floor of health and welfare in addition to personal freedom for the majority. Social democrats believe that the right to vote and

\footnotetext{
${ }^{59}$ William I. Robinson, "Pushing Polyarchy: The US-Cuba Case and the Third World," Third World Quarterly 16, no. 4 (December 1995): 643-659.

${ }^{60}$ ibid., 647.
} 
to be free from torture is insufficient without provisions to sustain healthy human beings, such as the equitable distribution of food, clothing, shelter, medicine, and education. ${ }^{61}$

On September 25, 1991, five days before being ousted from office, Aristide gave a speech at the United Nations that outlined some of his views on democracy, views that seem to reflect the spirit of popular and social democracy. In his Ten Democratic Commandments speech, Aristide presented three human rights that he believed were necessary complements to the rights to life, liberty, and the pursuit of happiness found in the U.S. Declaration of Independence. They were: the right to eat, the right to work, and the right for every individual to demand what they were owed in terms of social and economic justice. ${ }^{62}$ "To guarantee these rights, Aristide argued that his government would be based on the principles of 'justice, participation, and openness." ${ }^{, 63}$ So, for Aristide, democracy required the protection of economic and social rights alongside political rights, what Alex Dupuy calls a maximalist conception of democracy.

Aristide also argued that democracy in Haiti would be centered on serving the needs of the poor, the segment of the population that constituted the majority. Therefore, Aristide and his government promoted the Growth-with-Equity or Basic-needs model of development. In this model the state plays a central role in regulating the economy and redistributing resources in a manner that secures the welfare of the most vulnerable segments of the population. This means that the state structure and the development

\footnotetext{
${ }^{61}$ David P. Forsythe and Barbara Ann J. Rieffer, "US Foreign Policy and Enlarging the Democratic Community," Human Rights Quarterly 22, no. 4 (November 2000): 991.

${ }^{62}$ Dupuy, The Prophet and Power, 109-110.

${ }^{63}$ Dupuy, Haiti in the New World Order, 94.
} 
process is subjected to the 'logic of the majority,' and thus to the class and social interests of the majority. "The basic-needs approach begins by redefining development in class terms since it assumes that the development process is not neutral vis-à-vis the class

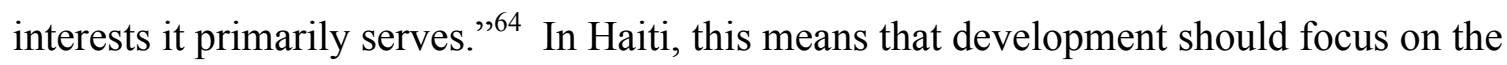
needs of the historically under-privileged majority: the peasants, the workers, women, the unemployed, the impoverished, and those in the informal sector. It means ensuring that these groups have the basics in terms of clean drinking water, access to land, healthcare, education, and protection from oppressive social relations. ${ }^{65}$

This form of democracy would also require a different conception of participation than what is often championed by Western democracy promoters. In order to achieve this maximalist democracy, politics could not be left up to the politicians. Rather, the people would have to be mobilized throughout Haitian society. It is important to remember that Lavalas initially rejected elections, political parties, and all the other institutional trappings of so-called Western democracy. Aristide initially criticized the idea that elections or candidates could possibly produce social transformation. Instead, they were viewed as tools to constrain and undermine popular demands. ${ }^{66}$ Aristide was simply capturing what was a popular sentiment at the time. "On every corner, Haitians selling mangoes or cassettes will tell you in disgust that...the very idea of elections is a grim joke in Haiti-a country in which a vote can be bought for a swig of rum; so-called political parties flourish for a season before fading away with the candidate's name, and

\footnotetext{
${ }^{64}$ Ibid., 95.

${ }^{65}$ Dupuy, The Prophet and Power, 109-110.

${ }^{66}$ Smith, "The New Occupation of Haiti," 2004.
} 
the notion of politics as a means to further the public good is utterly unknown., ${ }^{, 67}$ Instead of elections, democracy was viewed as the movement itself; organizing at the grassroots level, in the village and neighborhood committees, peasant associations, religious and lay brotherhoods, political clubs, women's groups, and associations of workers and the unemployed. Democracy was "a certain degree of freedom, a political space independent of government, which [had] been conquered inch by inch by the people." ${ }^{\text {,6 }}$ It was the multitude of popular organizations forming the "counterpower in the streets" 69 that finally brought democracy to Haiti, not elections or politicians.

Lavalas called for the decentralization of politics away from the capital, and the integration of structures that enhanced the popular participation of the underprivileged directly into formal decision-making structures. ${ }^{70}$ This model of democracy implies that the traditionally disenfranchised would have a significant role in the formation of the social, economic, and political policies that inevitably dictate the terms of their lives. ${ }^{71}$

Many scholars reject the notion that democracy necessarily entails particular economic and social rights, or even that it requires popular participation in politics. Much of these claims are viewed either as inconsequential or only secondary to the concept of democracy. Instead, these scholars have a much more limited perspective on what is essential to a proper definition of democracy. According to premier American political

\footnotetext{
${ }^{67}$ Danner, "The Struggle for a Democratic Haiti," 1987.

${ }^{68}$ Gerard Pierre-Charles and Margaret Low, "The Democratic Revolution in Haiti," Latin American Perspectives 15, no. 3, (Summer 1988): 65.

${ }^{69}$ Danner, "The Struggle for a Democratic Haiti,” 1987.

${ }^{70}$ Dupuy, The Prophet and Power, 109-110.

${ }^{71}$ Dupuy, Haiti in the New World Order, 95.
} 
scientist Robert Dahl, it is important to distinguish between democracy as an ideal and democracy as it is actually practiced. Dahl's aim in his seminal book, Democracy and Its Critics, "is to set out an interpretation of democratic theory and practice, including the limits and possibilities of democracy, that is relevant to the kind of world in which we live." ${ }^{, 2} \mathrm{He}$ places particular emphasis on moving away from a normative discussion of democracy, towards identifying the empirical characteristics of actual democratic societies. $^{73}$

While it is possible to outline what the ideal characteristics of democracy are, realizing such conditions is described by Dahl as utopian. ${ }^{74}$ These "advocates of democracy sometimes appear to believe that the values of democracy constitute the complete universe of value: if you could have a perfect democracy, they imply, then you would have a perfect political order, maybe even a perfect society." ${ }^{75}$ He wonders, "how much if any of the Greek vision of democracy is relevant to our times. ${ }^{, 76}$ Instead, he believes that it is necessary to establish a minimum threshold of meaningful democratic achievement.

In Democracy and its Critics, Dahl argues that many of the characteristics necessary to establish the democratic ideal of the Greek city-state simply do not exist in the modern world. The requirement in popular democracy that all citizens participate

\footnotetext{
${ }^{72}$ Robert A. Dahl, Democracy and its Critics (New Haven: Yale University Press, 1989$), 2$.

${ }^{73}$ Dahl, Democracy and its Critics, 6.

${ }^{74}$ Richard W. Krouse, "Polyarchy \& Participation: The Changing Democratic Theory of Robert Dahl," Polity 14, no. 3 (Spring 1982): 443.

${ }^{75}$ Robert A. Dahl, Democracy and its Critics (New Haven: Yale University Press, 1989), 8.

${ }^{76}$ Ibid., 20.
} 
directly in governing is no longer feasible in the contemporary setting, where cities themselves are often populated in the millions, and no longer act as the central political units of government they once were, subsumed in importance by the nation-state. Thus, the mechanisms of representation characteristic of modern democracies developed out of necessity. "As the number of citizens increases beyond a rather small if imprecise limit, the proportion of citizens who can assemble together (or, even if they can, have an opportunity to participate by anything more than voting) must necessarily grow smaller and smaller." $" 77$

There is little need for popular participation in Dahl's conception of polyarchic democracy. He argues that in modern democracies, citizens delegate enormous discretionary authority to not only elected officials, but to various administrative, bureaucratic, judicial, and even international bodies. ${ }^{78}$ In fact, "what we call 'democracy' - that is, a system of decision-making in which leaders are more or less responsive to the preferences of nonleaders - does seem to operate with a relatively low level of citizen participation." ${ }^{, 79}$ In fact, it requires it. In the polyarchic version of democracy, the accountability of government to the people is not established by mass participation in government, but by the bargaining and negotiating of organized groups of minorities within representative institutions. ${ }^{80}$ The endless mobilization of the masses is seen as simply disrupting this process.

\footnotetext{
${ }^{77}$ Robert A. Dahl, Democracy and its Critics (New Haven: Yale University Press, 1989), 216.

${ }^{78}$ Robert A. Dahl, On Democracy (New Haven: Yale University Press, 1998), 113.

${ }^{79}$ Krouse, "Polyarchy \& Participation," 443 - 444.

${ }^{80}$ Ibid., 443 - 444.
} 
According to many within the democratic transition literature, popular mobilization may be necessary for the dismantling of dictatorships and movement towards democracy, but it cannot continue indefinitely if democracy is to be sustained. Even Fatton argues that 'the moment of democratization, however 'electric' and dramatic, is an ephemeral historical event that promises much but offers little by itself." 81 After popular mobilization forces a shift from authoritarian rule, "a certain normality is subsequently reasserted" as most who were once active in the push for democracy depoliticize and de-radicalize themselves, either as a result of disillusionment or fatigue with politics. ${ }^{82}$ As popular forces lose energy, they are "eventually co-opted by better organized and financially more independent social forces...Formerly excluded parties and leaders of the dominant classes and middle sectors begin to reimpose their power."83 By this phase of the democratization process, the soft-liners (moderates) within the previous authoritarian regime, as well as the social classes that supported it, have come to tolerate "conflicts and demands, modifications in the rules of the game and institutional arrangements, as well as levels and patterns of popular demands and organization they would never have accepted at the beginning of the transition - and have found that they can live with them." ${ }^{84}$ But this is all predicated on the substantial demobilization of the popular movement and the emergence of moderate liberal democrats. The long-term

\footnotetext{
${ }^{81}$ Fatton, Haiti's Predatory Republic, 17.

${ }^{82}$ Guillermo O'Donnell, and Philippe C. Schmitter, Transitions from Authoritarian Rule: Tentative Conclusions about Uncertain Democracies (Baltimore: John Hopkins University Press, 1986), 26.

${ }^{83}$ Fatton, Haiti's Predatory Republic, 17.

${ }^{84}$ Guillermo O’Donnell, et al., Transitions from Authoritarian Rule, 27-28.
} 
process of implementing and consolidating democracy seems to require this. ${ }^{85}$ But is it the case that the popular sectors simply become fatigued with politics and decide to delegate their authority to elected officials, or are they systematically pushed out of politics through a variety of means, subtle and indirect as well as overt and coercive?

Dahl's polyarchy also rejects the notion that majority rule is a necessary feature of democracy. The two critical features of polyarchy, "elections combined with continuous political competition between individuals or parties," do not necessarily lead to majority rule, the leitmotif of a classical conception of democracy. ${ }^{86}$ Nevertheless, Dahl argues that somehow these processes advance popular sovereignty and political equality by increasing the "size, number and variety of minorities whose preferences must be taken into account by leaders. ${ }^{87}$ So, the distinction between dictatorship and democracy, as seen through a polyarchic lens, is not between minority and majority rule, but between government by a minority and government by a group of minorities. ${ }^{88}$ These groups of minorities, the result of the increasing diversity of the modern nation-state, make it nearly impossible to have the ancient city-state vision of democracy, according to Dahl. ${ }^{89}$ This pluralist view of society is echoed in Fatton's writings about the fall of the Duvalier dictatorship and the election of Aristide. According to Fatton, these events were made possible as a result of the rapid emergence of a variety of groups and organizations in civil society, and their ability to gain independence from the Duvalier regime and

\footnotetext{
${ }^{85}$ Fatton, Haiti's Predatory Republic, 17.

${ }^{86}$ Krouse, "Polyarchy \& Participation," 443.

${ }^{87}$ Ibid., 443.

${ }^{88}$ Ibid., 443.

${ }^{89}$ Dahl, Democracy and Its Critics, 217.
} 
eventually challenge its hold over their lives. Fatton particularly emphasizes the importance of "private spaces" in the resistance to authoritarian rule. "The prime characteristic of civil society is its capacity to fight the intrusion of the state...the development of pluralist and self-organizing civic associations bent on defending their own corporate interests against the exactions of the state has the potential to erode and perhaps block any authoritarian temptation. ${ }^{, 90}$ This orientation fundamentally negates the role of the state in establishing social justice.

Polyarchy facilitates the political participation of "a significant number of social groups and organizations that are relatively autonomous with respect to one another and to the government itself," in ways that were not feasible in the Greek city-state. For Dahl, polyarchy is necessary to establish democracy in pluralist societies. ${ }^{91}$ So, "polyarchy is neither pure majority rule nor unified minority rule. It is an open, competitive, and pluralistic system of "minorities rule." ${ }^{\prime 92}$ But are there no interests along which the majority of the population is aligned, particularly in poor underdeveloped societies such as Haiti? Is there no "common good" that the majority of Haitians can agree on? Are social groups truly autonomous from each other and from the state? Is there no role for the state in terms of social justice? Or is society simply fragmented into a variety of minority interest groups? Is the only role of civil society to prevent government intrusion into citizen's private lives? Or can civil society petition government to act towards a "common good"?

\footnotetext{
${ }^{90}$ Fatton, Haiti's Predatory Republic, 8.

${ }^{91}$ Dahl, Democracy and Its Critics, 219.

${ }^{92}$ Krouse, "Polyarchy and Democracy," 443.
} 
According to Dahl, the democratic process should not be expected to produce a particular result, principally some supposed "common good." Dahl argues that there have always been philosophical difficulties in determining what the common good is, and how we are to find it. "The lack of consensus on the meaning of the public good - and even on whether such a thing exists—creates genuine difficulties for public life." ${ }^{, 93}$ Another objection focuses on the impracticality of the notion of a "common good" to the establishment of real world democracy. "No one has been able to produce a concept of the common good that isn't either too general to serve as a relevant guide to collective decisions or else is appropriately specific but would lead to unacceptable policies." ${ }^{.94}$ Dahl also argues that reasonable notions of the common good can conflict with one another. The goals of "peace, order, prosperity, justice, and community-could conflict; conflicts would require tricky judgments about priorities and trade-offs. ${ }^{95}$ In a polyarchy, the idea of the "common good" is necessarily stretched more thinly than in the classical sense to incorporate the diversity of people that make up the citizenry and their many divergent beliefs and interests. ${ }^{96}$ The "common good" thus shifts away from a particular end objective, towards a focus on processes that allow for these diverse interests to be given their appropriate opportunity to participate in the bargaining process that polyarchy facilitates. But are all interests competing on an equal playing field?

\footnotetext{
${ }^{93}$ Dahl, Democracy and Its Critics, 282.

${ }^{94}$ Ibid., 286.

${ }^{95}$ Ibid., 282.

${ }^{96}$ Ibid., 218.
} 
For Robert Dahl and Samuel Huntington, polyarchic democracy is defined as a political system that is competitive, inclusive, and protects civil liberties. ${ }^{97}$ The seven institutions necessary to establish polyarchy, according to Dahl, are: (1) elected officials, (2) free and fair elections, (3) inclusive suffrage, (4) the right to run for office, (5) freedom of expression, (6) alternative sources of information, and (7) associational autonomy. ${ }^{98}$ Polyarchy thus is primarily a procedural conception of democracy, referring almost exclusively to the process of making decisions rather than the substance of policies. It is minimal, in that it focuses on the smallest number of attributes that produce a viable standard for democracy. Dahl and Huntington distinguish between what are primarily political aspects of a regime, and the social and economic relations that are potential causes or consequences of democracy rather than the features of democracy itself. $^{99}$ Thus, democracy is not to be judged based on the outcomes it produces, but based on the process used to make decisions. According to Dahl, "a possible defect in almost any process for making decisions is that it may fail to achieve desirable results. Even a just process might sometimes produce an unjust outcome." ${ }^{100}$ But what if this so-called "just process" continually produces unjust outcomes? And what kinds of injustices are tolerated by such a system, and what kinds are not?

\footnotetext{
${ }^{97}$ Renske Doorenspleet, "Reassessing the Three Waves of Democratization," World Politics 52, no. 3 (April 2000): 387.

${ }^{98}$ Dahl, Democracy and Its Critics, 221.

${ }^{99}$ David Collier and Steven Levitsky, "Democracy with Adjectives: Conceptual Innovation in Comparative Research," World Politics 49, no. 3 (April 1997): 434.

${ }^{100}$ Dahl, Democracy and Its Critics, 163.
} 
Despite debates on whether democracy should be reduced to a procedural concept or to its outcomes, Dahl considers polyarchy the highest possible level of real world democratic achievement. "While democrats describe many different visions of what the next stage of democracy should be, so far no country has transcended polyarchy to a 'higher' stage of democracy." ${ }^{, 101}$ For Dahl, these institutions, while criticized and treated with contempt by democratic idealists in countries with long histories of uninterrupted polyarchy, are often highly coveted by those who have lived in countries with extensive histories of authoritarian rule. ${ }^{102}$ But is it the case that those who live in repressive nondemocratic societies only wish to replicate the polyarchic structures of Western societies? Or do they have their own ideas about what democracy entails?

\section{ALTERNATIVE CONCEPTIONS OF DEMOCRACY}

A number of statements made by Aristide highlights that he understood his vision of democracy contrasted greatly with that of the United States and perhaps much of the Western industrialized world, and that he rejected the notion that theirs was the only possible model of democracy. "The popular democracy symbolized by the election of Aristide was not at all the democracy expected by the powerful. ${ }^{103}$ While he traced his vision of democracy to the French Revolution's Declaration of Human Rights of 1789, which is in line with much of Western democratic tradition, Aristide did not believe that "liberal and parliamentary democracy [was] in itself the indispensable corollary, the sole

\footnotetext{
${ }^{101}$ Dahl, Democracy and Its Critics, 223.

${ }^{102}$ Ibid.

${ }^{103}$ Farmer, The Uses of Haiti, 156.
} 
result and unique end of the movement for human rights."104 The democracy that Lavalas sought to establish in Haiti would not resemble a Haitian adaptation of liberal or classical parliamentary systems. ${ }^{105}$

While Aristide claimed to be building Haitian democracy on different grounds than that on which most modern democracies have been built, perhaps participation in elections sponsored by the U.S. and the international community was problematic to begin with. This is something that Aristide believed before joining the electoral race for president in 1990. Though some view his election as the product of the Haitian masses' usurpation of a U.S.-sponsored demonstration election ${ }^{106}$ intended to co-opt and bound the popular movement's demands to organize autonomously, participate in the country's politics, and share in the social and economic resources of the nation. ${ }^{107}$ Others, critical of any form of political process promoted by the United States, believed that Aristide's participation in the elections signaled a sort of deviation from the social movement that removed Baby Doc from power and now clamored for a more substantive democracy than formal elections would promise. Many who sought this systemic change believed that "Aristide would never participate in something as irremediably filthy as Haitian politics."108 They saw political parties as part of the traditional instruments of the

\footnotetext{
${ }^{104}$ Jean-Bertrand Aristide and Christophe Wargny, Aristide: An Autobiography (Maryknoll, NY: Orbis Books, 1993), 126.

105 Ibid., 9.

106 Ibid.

${ }^{107}$ Luc Smarth, "Popular Organizations and the Transition to Democracy in Haiti" in Community Power and Grassroots Democracy: The Transformation of Social Life (London: Zed Books, 1997), 102-126.

${ }^{108}$ Farmer, The Uses of Haiti, 128-129.
} 
powerful. "In truth... a very influential group of citizens was pressuring Aristide to run for president. These individuals were by no means radical; most were well-to-do residents of Port-au-Prince. ${ }^{109}$ In participating in U.S. sponsored elections, they believe that Aristide had already begun to deviate from the popular agenda. The people wanted "a president who is popular, and revolutionary!" "110

Others would come to argue that Aristide stifled the potential of Lavalas to genuinely establish democracy in Haiti. "While the masses erupted on the political stage and finally claimed their full rights as citizens, they have been unable - so far - to translate these rights into a coherent program of social and economic emancipation. This failure stemmed not only from the ruling classes' intransigent defense of their privileges, but also from the incapacity or unwillingness of the Lavalas movement and Aristide to implant viable institutional structures of popular representation. In fact, the authoritarian habitus ${ }^{111}$ reasserted itself within Lavalas; the messianism and 'one-manism' of past practices came to embody Aristide's presidential monarchism and absolute control of his Fanmi Lavalas party. He left no autonomous political space to his followers; Lavalas was Aristide, and Aristide was Lavalas." 112

\footnotetext{
${ }^{109}$ Ibid.

${ }^{110}$ Danner, "The Struggle for a Democratic Haiti," 1987.

111 "Habitus refers to a complicated repertoire of practices, attitudes, and behavior that are grounded in the material foundation of society. This repertoire can acquire a life of its own and in turn influence and shape material force. Habitus and political economy exist therefore in a dialectical relationship of continuous and mutually conditioning interaction. I contend that in the specific case of Haiti, the legacy of slavery and the plantation economy inherited from the predatory French colonial system engendered a powerful authoritarian habitus, which has in turn shaped decisively the country's form of governance" (Fatton, The Roots of Haitian Despotism, vii).

${ }^{112}$ Fatton, The Roots of Haitian Despotism, 203.
} 
These tensions between Aristide's participation in Western sponsored formal political processes and the vibrancy of the social movement for democracy embodied in Lavalas present another aspect in our attempt to engage the question, "what is democracy?" For Sheldon Wolin in his work Fugitive Democracy, "democracy is a project concerned with the political potentialities of ordinary citizens, that is, with their possibilities for becoming political beings through the self-discovery of common concerns and of modes of action for realizing them.." ${ }^{113}$ For Wolin, constitutional democracy, or polyarchy, is contrary to this project. Polyarchy is the restriction of democracy by a constitution. "It is not democratic or democratized constitutionalism because it is democracy without the demos as actor...In sum, a constitution regulates the amount of democratic politics that is let in."114 Dahl's statements about the origins of many of the institutions of polyarchy support Wolin's position on constitutional democracy. Many of the legislative bodies that became associated with democracy in the modern period initially represented the interests of aristocrats, commoners, the landed interest, and commercial interests. As popular forces challenged these exclusionary institutions, these legislative bodies were reformed by adopting electoral systems that would make their members more representative of the entire population. ${ }^{115}$

Nevertheless, these bodies remained elite controlled institutions. This is confirmed by additional statements made in Dahl's On Democracy. Dahl admits that,

\footnotetext{
${ }^{113}$ Sheldon S. Wolin, "Fugitive Democracy," in Democracy and Difference: Contesting the Boundaries of the Political (Princeton, N.J.: Princeton University Press, 1996), 31.

${ }^{114}$ Wolin, "Fugitive Democracy," 34.

${ }^{115}$ Dahl, Democracy and Its Critics, 215.
} 
"attached to the institutions of polyarchal democracy that help citizens to exercise influence over the conduct and decisions of their government is a nondemocratic process, bargaining among political and bureaucratic elites." 116 Despite acknowledging that popular control of elites is quite imperfect, Dahl argues that these elites are not despotic because elites' competing interests serve as checks and balances, and because elite bargaining occurs within the limits of the democratic process whereby periodic elections force them to keep their eyes on public opinion. ${ }^{117}$ For Wolin, this emphasis on elections is a farce. After elections, the demos "must now get its politics vicariously and passively through the pronouncements of television oracles, talk-show babble, and the political burlesque hustled by the pundits." ${ }^{, 18}$ The people are thus systematically excluded from the political process.

For Wolin, this form of democracy is not democracy at all because it rejects democracy's revolutionary impulse. If we look at democracy historically, we will find that it always emerges alongside revolution. The radical expansion of who was allowed to participate in politics was quite often a bloody affair, as the previously marginalized had to fight to be recognized as political equals. Democracy necessarily required revolution. "Revolution might be defined for our purpose as the wholesale transgression of inherited forms. It is the extreme antithesis to a settled constitution...Democracy was born in transgressive acts, for the demos could not participate in power without shattering the

\footnotetext{
${ }^{116}$ Dahl, On Democracy, 113-114.

${ }^{117}$ Ibid.

${ }^{118}$ Wolin, "Fugitive Democracy," 34.
} 
class, status, and value systems by which it was excluded." ${ }^{119}$ This is another way to think about democracy, one that sees the popular struggle for inclusion in political life as democracy itself. "Revolutions activate the demos and destroy boundaries that bar access to political experience. Individuals from the excluded social strata take on responsibilities, deliberate about goals and choices, and share in the decisions that have broad consequences... Thus revolutionary transgression is the means by which the demos makes itself political." ${ }^{120}$ Once the revolutionary phase ends and the institutionalization of politics begins, then democracy in the strongest sense begins to wane. The democracy of the revolutionary period becomes viewed as disorganized, inefficient, unstable, and even dangerous. This is where the distinction between Aristide's government and the Lavalas movement needs to be made. Aristide struggled in managing the tension between being the leader of a mobilized social movement, and being a political figure that became head of the Haitian state through polyarchic elections. In seeking to reconcile these two positions, he seemed to have neglected the principles of both.

\section{CENTRAL PROPOSITION}

The focus of this research will be an examination of the type of democracy and the particular processes by which Aristide and Lavalas pursued democracy in Haiti, with the understanding that their stated ideological positions vis-à-vis democracy should structure their preferences, dictate how they make decisions, and which decisions are made. This research paper will attempt to show that there are systematic differences in

${ }^{119}$ Ibid., 37.

${ }^{120}$ Ibid., 38. 
how Aristide and Lavalas pursued the objective of democracy in Haiti, and how democracy in Haiti was promoted by the United States, the international standard bearer of polyarchy; that these differences are critical to explaining the tensions that emerged from the beginning between Aristide, Lavalas, and the United States.

If the U.S. and the international community truly pursued a polyarchic vision of democracy in Haiti, there are sets of behaviors that we would expect to identify while outlining the history of American involvement in the country during the transition following the fall of Duvalier. This includes, first and foremost, respect for democratic procedures. Did the United States support free and fair elections? What was the political orientation of those whom the United States supported in Haiti? Did it side with those who were sincerely committed to the democratic process? A second important component of polyarchy is pluralism and the protection of civil liberties that fosters its development. To what degree did the United States accept the emergence of varying competing voices in Haitian politics, or support elements in Haitian society who were dedicated to the protection of civil liberties? To what degree did narrow elite interests capture U.S. policy towards Haiti?

If Aristide and Lavalas truly adhered to the dictates of popular democracy, we would expect policies that sought to decentralize the decision-making process so as to promote participation at the grassroots level, with the belief that such participation would lead to policies that sought to change the economic status quo towards greater redistribution of society's resources. To what degree did Aristide incorporate as many elements of the popular movement that he was supposed to represent into the formal decision-making process? Did Aristide concentrate political power in his administration 
or decentralize power? Also, did Aristide promote the gradual redistribution of wealth through the incorporation of a larger segment of the population, which in Haiti is predominantly poor, in the decision-making process, or did he support revolutionary armed conflict as a means of redistribution?

To examine these questions, my analysis of Aristide and the Lavalas movement's conceptualization of democracy will focus on the period of contested democratization in Haiti from 1986 to 1991, situating this period of democratic transition within a broader history of efforts by the Haiti's poor and marginalized to enter the political sphere as agents of their own political destinies. Following an overview of the Lavalas movement's place within a long historic struggle between Haiti's competing ruling classes and the masses for political prominence, my analysis turns to an examination of four distinct periods in Haiti's democratic transition: 1) the period of CNG-rule, from Jean-Claude Duvalier's departure on February 7, 1986 to the November 29, 1987 election-day massacre; 2) the Leslie Manigat government, which comes to power through the fraudulent military elections of January 17,1988 , and is ousted on June 20, 1988 by the military; 3 ) the period from the ascension of Henri Namphy's military regime following the coup, to the election of Jean-Bertrand Aristide on December 16, 1990; and 4) Aristide's first 8 months in power, from the inauguration of his government on February 7, 1991 until the military coup on September 29, 1991.

\section{METHODOLOGY}

Process-tracing will be the principle methodology used to analyze the degree to which a particular conception of democracy was influential in dictating the political 
actions of Aristide and the Lavalas movement. Process-tracing begins with the premise that there is always an element of indeterminacy when attempting to establish the cause of a historical event. There are often multiple variables, uncertainty as to how these variables interact with one another, and the weight of each variable in leading to the outcome under scrutiny. These outcomes are generally the product of an intricate chain of occurrences that coalesce over time in ways that often cannot be captured by the rigidity of regression analysis, which presents its explanations in terms of snapshots of covariation. Process-tracing sheds light on the dynamism of political processes and the intervening pressures and circumstances that may force outcomes away from intentions. $^{121}$

The strength of process-tracing lies in its ability to serve as a bridge between historical narrative and the social science obsession with determining causality. While historical narrative focuses on rich description to draw out general themes and trends, in process-tracing, potential hypotheses explaining an outcome are explicitly stated, and causation is determined by outlining the sequence of events from antecedent to outcome, and the relationship between events as they pertain to competing theoretical explanations. ${ }^{122}$ The researcher starts out with a set of competing hypotheses believed to explain the event in question. From each hypothesis stems predictions about the patterns that should be observed if the causal theory the hypothesis implies is valid. The researcher then proceeds to reconstruct the history of the outcome by identifying key

\footnotetext{
${ }^{121}$ Paul F. Steinberg, "New Approaches to Causal Analysis in Policy Research." Paper Presented at the Annual Meeting of the American Political Science Association, Hilton Chicago and the Palmer House Hilton, Chicago, Illinois, September 2, 2004, 2.

${ }^{122}$ Steinberg, "New Approaches to Causal Analysis," 1-2.
} 
moments, processes, or decisions that link these plausible hypotheses to the outcome of interest, with the objective of determining the consistency of each hypothesis in predicting the sequence of events leading to the outcome. ${ }^{123}$ "In essence, process-tracing breaks down complex chains of events into smaller pieces, and distant relations between antecedents and outcomes into more proximate cause-and-effect couplings. Causal processes are selectively decomposed further and further until the plausibility of the component cause-and-effect relationships is so high that further explanation is unwarranted." ${ }^{\prime 24}$ Thus, process-tracing goes beyond an explanation of a particular historical event to emphasize the stream of behaviors that led up to said event.

In terms of outlining Aristide and the Lavalas Movement's role in Haitian democratization, I will be referencing primary documents produced by the movement and its major actors, significant public statements and speeches, books and position papers written by Aristide, along with policies crafted by his administration. This will be supplemented by a close review of statements and declarations made by key individuals within the Lavalas Movement representing its various elements, from elites directly involved in the Lavalas government, those who were originally associated with the movement at the grassroots but inevitably became critics of the Aristide presidency, to Lavalas supporters on the ground within the public.

This research is significant to the study of democracy not only because Aristide and the Lavalas movement are reflective of broader historical trajectories in Latin

\footnotetext{
${ }^{123}$ Tulia G. Falleti, "Theory-Guided Process-Tracing in Comparative Politics: Something Old, Something New," Newsletter of the Organized Section in Comparative Politics of the American Political Science Association, 2006, 4-5.

${ }^{124}$ Steinberg, "New Approaches to Causal Analysis," 6.
} 
America and the Caribbean, but also because they speak to recent trends in other parts of the world. Aristide's particular conception of democracy flows from a movement that goes beyond Haiti, and is essentially entrenched in the broader ideological and political struggles that have characterized the region over the past 40 to 50 years. Aristide and the grassroots movement that emerged in Haiti are not divorced from the broader context of Latin American social thought, but rather deeply immersed within them. It is also important to note that the question of democracy in Latin America and the Caribbean is not yet resolved. Haiti itself is still undergoing a faltering transition to democracy 20 years after Aristide became Haiti's first democratically elected president. In other countries in the region there is a noticeable disillusionment with the direction of the kind of democracy that has been promoted by the United States and the region's elites, with the rise of figures such as Hugo Chavez in Venezuela and Evo Morales in Bolivia as markers of this disenchantment. As the Arab Spring spreads throughout the Middle East and North Africa, these questions regarding the content of democracy have reemerged once again.

\section{OVERVIEW OF CHAPTERS}

In the substantive chapters of this research project, I examine the coherence of the conceptions of democracy put forth by Aristide and the Lavalas movement, and how they interacted with U.S. democracy promotion in Haiti. The second chapter provides a broad historical analysis of the relationship between the Haitian state and society, with an emphasis on the historical exclusion and exploitation of the poor and working class majority, and their efforts to mobilize and enter the political arena on their own terms. 
The third chapter focuses on the circumstances that explain the timing of the popular uprising that became Lavalas in the 1980s. It highlights how various structural factors, domestic and international, as well as the emergence of ideologies such as liberation theology, came to produce the conditions for mass mobilization against the Duvalier dictatorship and for popular democracy. It also examines how these factors came to shape Aristide and Lavalas' ideas about what democracy would have to entail moving forward.

The following three chapters and the conclusion provide a close analysis of the critical junctures in Haiti's democratic transition from the fall of the Jean-Claude Duvalier regime on February 7, 1986 to the coup d'état against the democratically elected government of Jean-Bertrand Aristide on September 29, 1991. In these chapters, I track the dynamic interactions of the principal stakeholders in Haiti's democratic transition process across four distinct periods, outlining and analyzing how their rhetoric and actions align with competing conceptions of democracy. Particular emphasis is placed on analyzing critical junctures where top-down efforts by elites to establish polyarchy clash with bottom-up mobilizations of grassroots organizations to advance popular democracy. The fourth chapter focuses on the competition between the CNG military-government that comes to power in the aftermath of Jean-Claude's ouster in 1986, the newly returned exile political class, and the grassroots popular organizations, over the shape and tenor of Haiti's transition to democracy, and the breakdown of this process as a result of the November 29, 1987 election-day massacre. The fifth chapter analyzes the Leslie Manigat government that emerges out of the military-controlled elections of January 17, 1988, and efforts by U.S. surrogates in the Caribbean to legitimize the rigged elections in the face of opposition from the political class and the grassroots organizations. The sixth chapter 
focuses on the escalating confrontation between the military regimes that come to power following the ouster of Manigat on June 20, 1988 and a broadening mass movement for popular democracy. It examines Aristide's role as a critical defender of the poor and working class majority, and their grassroots movement to actively resist repression or cooptation in support of particular processes of democratization that marginalize their agenda as autonomous and equal political actors. It concludes with an examination of the 1990 presidential campaign and election, particularly emphasizing some of the tensions between those pushing for participation in the elections and those advocating for more radical measures. The conclusion discusses some of the issues faced by Aristide in converting an election victory on the wave of popular mobilization amongst the poor and working classes, into policies that meet the objectives of the grassroots organizations and their vision of popular democracy, once he is in the presidency. The difficulties faced by Aristide in power, and his inevitable removal from power by the military, point to a broader question concerning whether processes that were crafted for a polyarchic understanding of democracy, can be co-opted for the purpose of advancing the agenda of popular democracy. 


\section{CHAPTER II}

\section{DISCIPLINING HAITI'S LABORING MASSES}

\section{INTRODUCTION}

Haiti's history of political struggle is a long one of competition between two principle factions of the elite, those utilizing populism to mask one-man rule, and others espousing republican constitutionalism to mask oligarchy. Behind the veils of benevolent tutelage, a parallel struggle between these elite cliques and the poor masses has served as a constant. In both instances, whether intra-elite competition or class conflict, political strife has revolved around who was to have dominion over Haitian land and labor, principally through control of the state apparatus. Traditionally, these tensions have become most apparent during periods of transition from overt authoritarian rule, when the possibilities of political liberalization and mass mobilization were the greatest: after the demise of French colonial rule and establishment of the post-colonial Haitian state; after the overthrow of the Boyer regime in 1843; after the U.S. occupation and eventual Revolution of 1946; and in the aftermath of the Duvalier dictatorship in 1986. This chapter outlines this history of confrontation, highlighting periods where the intrigues of rival elite factions have opened up space for the laboring classes to mobilize and potentially overturn elite rule, espousing their own vision for a Haiti where they are empowered. 


\section{PRESERVING THE PLANTOCRACY}

While the revolution back in metropolitan France beginning in 1789 seemed to portend similar revolutionary changes for the black slave masses in Saint-Domingue, the colonial name for the country that became Haiti, efforts to maintain the plantation system were simply clothed in the language of revolutionary egalitarianism. In August 1793, two years after the enslaved Africans set about freeing themselves through mass insurrection, commissioner Léger-Félicité Sonthonax of the newly established French Republic declared them free. Nevertheless, this was not done to end the plantation economy that had contributed so greatly to French prosperity, but rather to ensure that its principle structures remained intact. ${ }^{125}$

Though "no longer...the property of another," the commissioner explained that the newly freed were to show their appreciation for this gift by rejecting indolence and banditry, and producing for the Republic. ${ }^{126}$ As the former slaves abandoned plantation labor to expand their garden plots, the French commissioner decreed: "this land does not belong to you. It belongs to those who have bought it or inherited it from those who first acquired it, ${ }^{, 127}$ essentially, their former masters. What the self-proclaimed abolitionists had hoped for was a gradual end to slavery that did not fundamentally change the distribution of land or the relationship between those that worked it and the planter class who once owned them. ${ }^{128}$ Fearful that continued mass insurrection during a period of

\footnotetext{
${ }^{125}$ Laurent Dubois, Avengers of the New World: The Story of the Haitian Revolution (Cambridge, Mass: Belknap Press of Harvard University Press, 2004), 161.

${ }^{126}$ Ibid., 164.

${ }^{127}$ Ibid., 185.

${ }^{128}$ Ibid., 161.
} 
parallel upheaval in the French metropole provided an opening for rival European powers to shape events on the island, legal emancipation had simply been a ruse to retain France's most prized sugar colony. ${ }^{129}$ Forced to sign three-year contracts, the former slaves were to remain "attached" to their plantations, under the close supervision of the colonial army. In return, they were granted subtle improvements in disciplinary practices and some remuneration for their work. ${ }^{130}$ Only those incorporated into the colonial army were legally free from plantation labor, ${ }^{131}$ setting a precedent whereby militarism became one of few avenues of upward mobility for the descendants of former slave laborers.

When black general Toussaint Louverture rid the colony of its French Commissioners, again there was hope for the dismantling of the forced labor regime, but the project to maintain the plantation system in the name of the French Republic continued. While Louverture's Constitution of 1801 declared that "there can be no slaves in Saint-Domingue"...that "all men here are born, [will] live, and die free and French,",132 it was written exclusively by a committee of white and mulatto property owners, completely excluding the voice of the former slaves. ${ }^{133}$ Rather than challenge the status quo, it established the inviolability of the property rights of the planter class and imposed forced labor on the cultivateurs, the title given to the former black slaves to mask their

\footnotetext{
${ }^{129}$ Ibid., 192.

${ }^{130}$ Ibid., 219-220.

${ }^{131}$ Ibid., 164.

${ }^{132}$ Carolyn E. Fick, "The Saint-Domingue Slave Revolution and the Unfolding of Independence, 17911804," in The World of the Haitian Revolution (Bloomington: Indiana University Press, 2009), 183.

${ }^{133}$ Jeremy Popkin, A Concise History of the Haitian Revolution, (Chichester: Wiley-Blackwell, 2011), 107 $-109$.
} 
continued enslavement. ${ }^{134}$ Having appropriated the abandoned plantations of the colonialists who had fled Saint-Domingue, Louverture and the other black military officers sought to maintain plantation agriculture at the expense of the laboring black masses. "Rather than being promised any possibility of obtaining their own land, the mass of black fieldworkers were reminded that 'the colony...cannot afford the slightest interruption in work on its crops,' and that they were subject to the authority of the landowners employing them." 135 The multiracial egalitarian society that Louverture envisioned only applied to the landed elite, both old and new, not the vast majority of laborers, who were subject to "an iron-clad regime of discipline and repression under the direct supervision and inspection of the military generals." ${ }^{\prime 136}$

Upon the betrayal and exile of Louverture by French General Charles Leclerc, sent to quell the insolence of the gilded negros, another black general, Jean-Jacques Dessalines, took over where Louverture left off. Again, the possibility of a radical break from the past emerged. While defeating the invading French forces and leading the drive towards independence, contradictions persisted between his unequivocal declarations that the blacks of Saint-Domingue would never again be enslaved, and his efforts to maintain the plantation economy. Where Louverture sought to preserve the colonial relationship, enthusiastically championing the ideals of French Republicanism, Dessalines rejected them altogether for their barefaced hypocrisy. In his Act of Independence, Dessalines

\footnotetext{
${ }^{134}$ Ibid., 111.

${ }^{135}$ Ibid., 109 - 110.

${ }^{136}$ Fick, "The Saint-Domingue Slave Revolution," 184.
} 
called "into question the politics of European cultural models." ${ }^{137}$ Unlike Toussaint, Dessalines's more recent experience of slavery and illiteracy may have provided him with the necessary distance from European worldviews to fundamentally challenge their tropes concerning liberty and freedom. Thus, he referred to the French as the enemies of the rights of man, ${ }^{138}$ and the 'tree of liberty,' as the "ancient tree of slavery and prejudice," which he called upon the former slaves to bring down with their axes. ${ }^{139}$

Dessalines' constitution sought to sever the country's ties with its colonial past, by changing the its name from Saint Domingue to Hayiti, the Amerindian appellation for the island before European colonization; ${ }^{140}$ declaring that all Haitians were to be addressed as Blacks, ${ }^{141}$ including Polish defectors of Leclerc's French expedition who fought alongside the former slaves, ${ }^{142}$ and that "no white man...shall put his foot on this territory with the title of master or proprietor." ${ }^{\text {"143 }}$ While legally considered property rather than people, labeled "brigands" of a rouge colony, embargoed and encircled by

\footnotetext{
${ }^{137}$ Deborah Jenson, "Dessalines's American Proclamations of the Haitian Independence," The Journal of Haitian Studies 15, no. 1 \& 2 (2009): 76-77.

${ }^{138}$ Julia Gaffield, "I Have Avenged America," Haiti and the Atlantic World (blog), August 2, 2013, http://haitidoi.com/2013/08/02/i-have-avenged-america/.

${ }^{139}$ Jenson, "Dessalines's American Proclamations," 77.

${ }^{140}$ David Geggus, Haitian Revolutionary Studies (Bloomington, IN: Indiana University Press, 2002), 207.

${ }^{141}$ David Nicholls, From Dessalines to Duvalier: Race, Colour and National Independence in Haiti (Cambridge: Cambridge University Press, 1979), 38.

${ }^{142}$ Zdzislaw P. Wesolowski, "The Polish Contribution to the Haitian War of Independence," Toussaint Louverture Historical Society (blog), http://toussaintlouverturehs.org/PolishContribut.htm.

${ }^{143}$ Bob Corbett, "The 1805 Constitution of Haiti," Bob Corbett's Haiti Page, Webster University, April 4, 1999, http://www2.webster.edu/ corbetre/haiti/history/earlyhaiti/1805-const.htm.
} 
European slave-holding powers, ${ }^{144}$ Dessalines declared, "we dared to be free when we were not free, by ourselves and for ourselves." ${ }^{, 145}$

Despite the world-shattering character of the Haitian Revolution in terms of its challenge to notions of racial hierarchy, the inheritors of the new Haitian state, the ancien libres and negres libres, persisted in their efforts to restore the plantation economy and the labor discipline it entailed. The fight against white San Domingan colonists and French Napoleonic forces required a tenuous alliance between two groups: anciens libres and nouveaux libres. ${ }^{146}$ Ancien libres (literally old freemen) were members of the military and political elite who were free prior to the revolutionary period. Typically the mixed raced descendants of the white planter class, they occupied a class position between the white planter elite (the grand blans) and white urban artisans, working class, and plantation managers (the petit blans). But in terms of color, they occupied a caste position between the petit blans and the black slave masses. Referred to as gens de colour (gentleman of color), they were often French-educated, owned land and slaves passed down from their white planter ancestors, had established their own coffee plantations, and were thus relatively wealthy. Prior to the mass mobilization of the enslaved population for freedom, the primary concern of the gens de colour was equal legal and political status with the white colonialists, not the abolition of slavery. ${ }^{147}$ Throughout the

\footnotetext{
${ }^{144}$ Deborah Jenson, Beyond the Slave Narrative: Politics, Sex, and Manuscripts in the Haitian Revolution (Liverpool: Liverpool University Press, 2011), 112 \& 152.

${ }^{145}$ Ibid., 81 .

${ }^{146}$ David Nicholls, From Dessalines to Duvalier, 37.

${ }^{147}$ Michel-Rolph Trouillot, "The Inconvenience of Freedom: Free People of Color and the Political Aftermath of Slavery in Dominica and Saint-Domingue/Haiti," in The Meaning of Freedom: Economics, Politics, and Culture after Slavery (Pittsburgh: University of Pittsburgh Press, 1992), 148.
} 
revolutionary period this class shifted back and forth between support for and resistance to French colonialism as they were caught between the threat of white racial oppression and the insurrection of the former slaves.

Within the class of freedmen, gens de couleur, as freeborn persons of color, were to be distinguished from negres libres (free blacks), who were born into slavery, but had gained their freedom at some point in their lives, like Louverture and Dessalines. As they came to occupy top positions within the revolutionary army, and eventually the postcolonial state, they served as a rival faction to the gens de couleur. They, along with the masses of blacks that freed themselves through revolution, made up the nouveaux libres (literally, new freemen). Within this population of new freemen, there were further distinctions. Most free blacks were born in Saint Domingue, and thus as creoles were of higher status than blacks born in Africa, the bossales. Occupying important positions within the military hierarchy, many free blacks were able to acquire plantations as French planters abandoned them for fear of being massacred by their former slaves. So as the colony moved towards independence, the emergence of an autonomous small-holding peasant-society outside of the plantation order threatened the newfound positions of prominence of both the free blacks and the old free gentlemen of color, who sought total control over land and labor.

These two groups sought to exclusively dictate the direction of the post-colonial state and society. "Of the thirty-seven officers who signed the declaration of independence, more than two-thirds were of mixed racial descent, and none was African 
[born]. ${ }^{, 148}$ It is doubtful that the writing of the subsequent constitution was any different. Yet again, those who claimed to speak for the Haitian masses were exclusively from the propertied military elite. Though Dessalines' 1805 constitution would strongly reject slavery and racial hierarchy, the population over which the new state would rule were to be subjects rather than citizens. While Louverture's Constitution of 1801 made pretenses to liberalism, Dessalines' 1805 Constitution did not bother. The country was divided into six military divisions. There was no legislature, only a Council of State made up of the country's generals. The Emperor, Dessalines, alone served as the head of the armed forces, made the laws, collected taxes, and named his successor. No mention was made of broader civil or political rights. ${ }^{149}$

Between Louverture and Dessalines, two traditions emerged, feigned Republicanism in adherence to Western cultural values, alongside unabashed autocracy in the name of black-nationalism. These two traditions would characterize the country's post-independence history. ${ }^{150}$ With Dessalines' assassination in 1806 , the nation was divided in two, between what became the Kingdom of Haiti in the North, with black general Henri Christophe as ruler, and the Republic of Haiti in the South, with the mulatto general Alexandre Pétion as president. The mulattoes were always more dominant in the South and West regions of the country, while the blacks held political

\footnotetext{
${ }^{148}$ Geggus, Haitian Revolutionary Studies, 208.

${ }^{149}$ Popkin, A Concise History of the Haitian Revolution, 138-139.

${ }^{150}$ Alex Dupuy, "Toussaint-Louverture and the Haitian Revolution: A Reassessment of C.L.R. James's Interpretation," in C.L.R. James: His Intellectual Legacies (Amherst: University of Massachusetts Press, 1995), 113.
} 
and military power in the Artibonite and Northern regions. ${ }^{151}$ The constitution of the Northern Kingdom unambiguously asserted Christophe's autocratic rule, in the tradition of Dessalines. It rejected the notion of democracy all together as nonsensical, arguing that distinctions in rank were natural, and not incompatible with liberty. The population was believed to be "unstable by character, averse to labour and tending to disorderly conduct...[and] therefore liberty must be contained within due bounds."152

By contrast, the constitution of Petion's Republic presumably limited the power of the president. Proponents of the regime claimed that in the Republic, all were equal, and that government was "the result of a contract between the people and their leader...sovereignty resid[ing] in the body of the people."153 To a great extent, these pronouncements belied what was in fact a military oligarchy. "A careful reading of the constitution as well as an examination of the practice, would reveal that, despite talk about the sovereignty of the people, real power was in the hands of a small selfperpetuating elite."154 Denunciations between the Northern Kingdom and the Southern Republic simply masked what was truly a conflict between two elite groupings, neither "particularly interested in the welfare of the mass of former slaves, though both groups relied on their support."

In the Northern Kingdom, Henry Christophe's Code Henry of 1812 gave the state military the responsibility of ensuring that cultivateurs, the traditional agricultural

\footnotetext{
${ }^{151}$ Nicholls, From Dessalines to Duvalier, 38.

152 Ibid., 58-59.

${ }^{153}$ Ibid., p. 58.

${ }^{154}$ Ibid., p. 59.

155 Ibid., p. 60.
} 
laborers, remained confined to the plantations they had once worked as slaves. ${ }^{156}$ Military campaigns were organized to round up and return so-called fugitive laborers to their respective plantations. Their subsistence gardens and food crops were destroyed, their modest parcels of land returned to the state, and the sale of small plots that fragmented plantations outlawed. ${ }^{157}$ The Kingdom also drafted many former slaves to work on state construction projects, particularly fortifications and palaces, making it clear that though Haitians were legally free, in reality, they were viewed as property of the state. Through an extensive network of spies and informants, Christophe ensured that laborers remained confined to Northern plantations and construction sites. ${ }^{158}$

Similarly, Jean-Pierre Boyer, heir to Petion's Republican tradition, utilized the state to secure labor for the plantation economy. Upon reuniting the north and south after Christophe's suicide, Boyer issued the Code Rural of 1826 to return those who had escaped to live an autonomous existence back to the plantations. Boyer's "Republic" outlawed subsistence farming and cattle-raising, as these activities "produced little or no revenue for the state." 159 The "Republic" relied on an island-wide network of jails and prisons to support forced labor policies. "Provincial capitals and regional commercial centers all had their own prisons ... demonstrat[ing] the importance of regional prisons as pillars of the republican regime." 160 Under Boyer, the Code Rural "officially classified

\footnotetext{
${ }^{156}$ Johnhenry Gonzales, "The War on Sugar: Forced Labor, Commodity Production and the Origins of the Haitian Peasantry, 1791-1843," Ph.D. Dissertation, University of Chicago, Illinois, 2012, ProQuest Dissertations Publishing (3526305), 50.

${ }^{157}$ Ibid., 43, 65.

${ }^{158}$ Ibid., 69-70.

${ }^{159}$ Ibid., 74-75.

${ }^{160}$ Ibid., 86-87.
} 
the rural population as a distinct group with limited rights and subject to special regulations." ${ }^{\prime 161}$ So the legal system that emerged in Haiti is one where the majority of the population did not have equal status. Interestingly enough, the rounding up of "escaped" peasants and their confinement on plantations occurred alongside the liberal electoral politics of the period.

Despite the conflicts that emerged between the two elite factions, they were in concert when it came to preserving plantation production for export and the forced labor that relied on. Both were fundamentally "opposed [to] the formation of an independent and landed peasantry," ${ }^{162}$ which would undermine their control over land and access to cheap pliant labor. Adherents of both the Republican tradition and the authoritarian tradition would continue in their efforts to build the nation by subduing the mostly African-born bossales, who once served as the draft animals of the colonial economy, into the status of cultivateurs confined to plantations. ${ }^{163}$

\section{THE REVOLUTION OF 1843}

Throughout this period of political evolution, from the first armed slave insurrection to post-colonial independence, efforts to sustain the plantation economy consistently came into direct conflict with the substantive conception of freedom held by the mass of former slaves. During the colonial period under Louverture, the laboring black masses revolted against their status as cultivateurs for the French Republic. In

\footnotetext{
${ }^{161}$ Popkin, A Concise History of the Haitian Revolution, 155.

${ }^{162}$ Alex Dupuy, "Toussaint-Louverture and the Haitian Revolution," 114.

${ }^{163}$ Gonzales, "The War on Sugar," 50.
} 
October 1801, Louverture's own adopted nephew, Hyacinthe Moise, led an uprising in the North against the system of forced labor. Unwilling to enforce the labor regulations, ${ }^{164}$ believing that the black masses were being exploited for the benefit of France, Moise called for popular land redistribution, making him "the idol of the black workers. ${ }^{\not 165}$ With Moise arrested, tried, and executed, Louverture would have commanders Henry Christophe and Jean Jacque Dessalines, two future heads of the Haitian post-colonial state, brutally suppress the rebellion. ${ }^{166}$

Other figures would also lead popular resistance movements against Louverture's forced labor regime. Guerilla fighters and maroons such as Petit Noel, Sylla, and SansSouci in the northern mountains, as well as Lamour Dérance in the Western Province, mounted countless attacks against Louverture. The conflict between these guerilla leaders and the black generals of the colonial army was "over the land and class questions in San Domingo in terms of which class would dominate and in whose interests would the colony be reorganized. ${ }^{, 167}$ While Toussaint and the black military officers contended that a plantation system based on wage labor was the most effective and efficient means to preserve the freedom of the black masses because it generated wealth for the colony and France, ${ }^{168}$ the reality was that "this new class of military officers and property owners

\footnotetext{
${ }^{164}$ Popkin, A Concise History of the Haitian Revolution, 112-113.

${ }^{165}$ Kona Shen, "Touissaint-Louverture in Power, 1796-1801," History of Haiti, 1492-1805, Brown University Department of Africana Studies, http://library.brown.edu/haithistory/8.html.

${ }^{166}$ Popkin, A Concise History of the Haitian Revolution, 112-113.

${ }^{167}$ Dupuy, "Toussaint-Louverture and the Haitian Revolution," 112.

${ }^{168}$ Ibid., 110.
} 
had its own interests that opposed those of the former slaves." 169 The agenda of the formerly enslaved population was radical land reform, which would transform them into smallholders, depriving the emergent black landowning class of a cheap and exploitable labor force. ${ }^{170}$ It is only with the betrayal and exile of Louverture, and subsequent French efforts to reestablish direct rule, that the guerilla leaders would come to fight alongside the former black and mulatto generals of the colonial army in an all-out war for independence. Nevertheless, these class tensions would persist throughout the country's history. ${ }^{171}$

They reappeared immediately after independence. Though Dessalines sat atop the militarized Haitian state that maintained the forced labor regime, pressure from the peasants may have been pushing him towards reform. "In a well-known statement Dessalines referred to the unjust situation whereby the anciens libres retained all the private property of the country, while the former slaves remained without land." 172 Having nationalized all the land previously belonging to the French, and establishing a state agency to manage their distribution to those who fought in the revolution, it was believed that Dessalines hoped to lessen the stark concentration of private land in the hands of the affranchis and black military elite.

"How does it come to pass that since we have chased away the colonists, their children are claiming their property? The Blacks whose fathers are in Africa will then have nothing? Be careful of yourselves, Negroes and Mulattoes, we have all fought against the Whites; the property we have conquered in spilling our blood

\footnotetext{
${ }^{169}$ Ibid., 112.

${ }^{170}$ Ibid.

${ }^{171}$ Popkin, A Concise History of the Haitian Revolution, 123-124.

${ }^{172}$ Nicholls, From Dessalines to Duvalier, 38.
} 
belongs to all of us; I insist that it be shared with equity." "173

For many, it is unclear whether Dessalines sought to divide and distribute national lands as broadly as possible, creating a nation of small-holders, or if state ownership was simply a means to improve the position of the new black elite in relation to the traditional mulatto elite. ${ }^{174}$

As Dessalines undertook his agenda of nationalizing land, both the ancien libres and the negres libres increasingly felt threatened, ${ }^{175}$ assassinating him for challenging the concentration of land in their hands. ${ }^{176}$ The two principle conspirators would become heads of the successor states, the black general, Christophe, and the mulatto general, Petion. As the two segments of the elite vied for power, former slave Jean-Baptiste Perrier, popularly known as Goman, ${ }^{177}$ lead a peasant revolt in the South, eventually establishing the Peasant Republic from 1807 to $1819 .{ }^{178}$ According to Pétion, Goman's peasant insurrection represented legitimate discontent amongst the cultivateurs, who were never considered actual citizens of the republic and thus treated unjustly. Only with the reuniting of the country under Boyer, after Pétion's death, would the Peasant Republic be

\footnotetext{
${ }^{173}$ Lyonel Paquin, The Haitians, Class and Color Politics (Brooklyn, N.Y.: Multi-Type, 1983), 29.

${ }^{174}$ Nicholls, From Dessalines to Duvalier, 38.

${ }^{175}$ Paquin, The Haitians: Class and Color, 29.

${ }^{176}$ Nicholls, From Dessalines to Duvalier, 40.

${ }^{177}$ Kate Ramsey, The Spirits and the Law: Vodou and Power in Haiti (Chicago: University of Chicago Press, 2011), 282.

${ }^{178}$ David Nicholls, "Rural Protest and Peasant Revolt, 1804-1879," in Haitian History: New Perspectives (New York: Routledge, 2013), 183.
} 
dismantled. ${ }^{179}$ This pattern would be replicated time and again throughout Haitian history. As factions of the elite became preoccupied with fighting one another, the working classes would seize the moment to mobilize for systemic change and substantive participation in the political process. Once these competing factions realized the outright threat to their class positions, they would shift from conflict to cooperation in order to repress the potential revolution from below. This narrative would play itself out again during the Revolution of 1843 .

In 1843 , the demands of a liberal faction of the elected elite for greater checks on presidential power and a liberalization of Haiti's politics provided an opportunity for the peasantry to push for the "freedom, political rights, and social justice that... their (grand) parents — had fought for in the revolution and war of independence...."180 Most of the liberals spearheading what would become the Revolution of 1843 were from the segment of the mulatto elite left outside of Boyer's ruling circle. On September 1st, 1842, at a meeting of the "Society of the Rights of Man and Citizen," they proclaimed a "Manifesto...to their Fellow Citizens" announcing their grievances against Boyer's dictatorial rule. ${ }^{181}$ According to the Society, the central causes of tyranny in Haiti were the defects of the constitution, which gave the Senate and the President powers so great and absolute that the sovereignty of "the people" and the inalienability of their rights had

\footnotetext{
${ }^{179}$ Ibid., 185.

${ }^{180}$ Mimi Sheller, "The Army of Sufferers: Peasant Democracy in Early Republic Haiti" New West Indian Guide 74, no. 1-2 (2000): 38.

181 "The Praslin Manifesto by Beaubrun Ardouin (1796-1865)," Island Luminous, http://islandluminous.fiu.edu/part04-slide11.html.
} 
been forgotten. ${ }^{182}$ The Manifesto declared the formation of a new constituent assembly with the power "to create 'a democratic constitution that would openly proclaim the sovereignty of the people and the principle of timely elections for most public positions,' including most notably the presidency." 183

Even as they sought to displace Boyer in the name of popular sovereignty, the Society was particularly distrustful of the masses of impoverished peasants. While the revolution needed the support of peasant laborers, emphasis was placed on leading them rather than having them develop their own agenda ${ }^{184}$ Their distrust was particularly embodied in the person of Charles Rivière-Hérard, the regional military commander who was declared president after the Manifesto's signing. "He recommended 'above all that no cultivators be introduced into the ranks of the national guard, which must be composed only of proprietors, sons of proprietors, farmers, and under-farmers, etc.,",185 those who had a vested interest in preserving the plantation economy. So, while they sought to overthrow Boyer's autocratic rule, they were also concerned with preserving the confinement of cultivateurs to their agricultural work.

Another line of contention emerged between the Society and the black elite, led by the large landowning Salomon family. They argued that the overthrow of Boyer simply empowered the petit milats to the exclusion of the black masses, who the

\footnotetext{
182 "Manifeste Du 1er Septembre 1842," in Recueil Général Des Lois \& Actes Du Gouvernement d'Haiti, Digital Library of the Caribbean (dLOC), http://www.dloc.com/UF00074014/00004/275x?vo=2, 118; "The Praslin Manifesto by Beaubrun Ardouin (1796-1865)," Island Luminous, http://islandluminous.fiu.edu/part04-slide11.html.

183 "The Praslin Manifesto."

${ }^{184}$ Sheller, "The Army of Sufferers," 40.

${ }^{185}$ Ibid., 41.
} 
Salomons claimed to represent. Pronouncing that this new faction threatened to destroy the black small landowners, the Salomons denounced it and Boyer for having been " "the oppressor of the black class' and called upon the new government to give justice to the blacks." ${ }^{186}$ General Herard subsequently imprisoned the Salomons, but they would eventually escape and call for mass revolt. Though this initial insurrection was put down, and the Salomons exiled to Jamaica, not long after, the peasants would mobilize again, autonomously, as Herard became preoccupied with quelling a separate rebellion on the eastern part of the island of Hispaniola incorporated into Boyer's Republic at the time. "Calling themselves 'the Army of Sufferers' "the cultivators [of the South]...armed themselves with rifles and pikes of hardwood, [from which they came to be known as the Piquets], and organized themselves into cavalry and infantry.","187

Though this uprising is often portrayed as emerging due to color conflict, the peasants' agenda was one based on class rather than color. Believed to be in reaction to Boyer's Rural Code of $1826,{ }^{188}$ the Army of Sufferers would emerge from the same regions where the Peasant Republic had existed under Goman. Under the leadership of black peasant farmers and former soldiers, Jean-Jacques Acaau and his lieutenants, the Army of Sufferers demanded respect for the constitution, national public education, and economic reforms reducing the price of staple imports, establishing fairer compensation for their crops, and reducing their work load. Though they initially pursued their agenda

\footnotetext{
${ }^{186}$ Nicholls, From Dessalines to Duvalier, 77.

${ }^{187}$ Sheller, "The Army of Sufferers," 45-46.

${ }^{188}$ Nicholls, From Dessalines to Duvalier, Endnote 43, 275.
} 
through public addresses and proclamations, ${ }^{189}$ as the Herard military regime increasingly engaged in outright repression, the Army of Sufferers became radicalized. Ultimately, they sought to confiscate lands owned by wealthy elites for distribution to those who worked them, as their predecessors had done during the Haitian Revolution and after. ${ }^{190}$ What began as a struggle between different elite factions for control of the state, broadened into a fundamental challenge to the distribution of power and resources along class lines.

The Army of Sufferers espoused a clear class-based ideology, identifying their enemies in terms of class and status rather than simply skin color. ${ }^{191}$ For Acaau, "the rich Negro who can read and write is mulatto; the poor mulatto who cannot read nor write is Negro," 192 meaning that "all poor mulattoes should be considered as blacks, and...all rich blacks should be considered as mulattoes." ${ }^{, 193}$ So, for the Army of Sufferers, color was simply a proxy for class. The Piquets fought in the name of the peasant laborers, against the large landowning elite, whether mulatto or black. In a show of solidarity, their leaders "utilized the dress and Kréyol speech of the peasantry," symbolically reflecting their ultimate goal of opening Haitian politics to the peasantry. ${ }^{194} 195$ Their ideology would be called "negro communism," likened to the Revolutionary wave of 1848 in Europe. ${ }^{196}$

\footnotetext{
${ }^{189}$ Sheller, "The Army of Sufferers," 51.

${ }^{190}$ Nicholls, From Dessalines to Duvalier, 77-78.

${ }^{191}$ Sheller, "The Army of Sufferers," 49-50.

${ }^{192}$ Ibid., 48-49.

${ }^{193}$ Nicholls, From Dessalines to Duvalier, 77-78.

${ }^{194}$ Sheller, "The Army of Sufferers," 48-49.
} 
As Herard was removed and the black revolutionary hero, General Philippe Guerrier, declared president, it became clear that the black elite never truly represented the interests of the black masses. While Guerrier's presidency did not immediately halt the peasant insurgency, eventually many of the Piquet leaders would acquiesce to the new government. ${ }^{197}$ Recalled from exile, the large landowning Salomon family would play a central role in reestablishing elite rule, using "their influence in the South to contribute to the neutralization of the Acaau movement in 1844." Lysius Salomon would become a senator and influential minister, but never pushed for the democratic inclusion of the peasantry for which 'the Army of Sufferers' had fought. ${ }^{198}$ Black elite claims made in the name of Haiti's black peasants were simply a means to gain access to positions of prestige and power vis-à-vis the better-established mulatto elite. ${ }^{199}$

Where they could not displace their rivals, they would be contented to share power, at least for a time. Guerrier became one of many presidents from the black elite that would serve to mask the continued political and economic dominance of the mulatto faction, in what came to be known as the politique de doublure (rule by proxy). The image of a black figure in the top political position, was supposed to distract the poor black majority into believing their interests were being attended to. But black figurehead presidents like Guerrier (1844 - 45), Jean-Louis Pierrot (1845 - 46), and Jean-Baptiste Riché (1846 - 47), were described at the time as noirs rather than nègres. Since the term

\footnotetext{
${ }^{195}$ Ibid., 51.

${ }^{196}$ Ibid., 49-50.

${ }^{197}$ Nicholls, "Rural Protest and Peasant Revolt," 187.

198 Sheller, "The Army of Sufferers," 49-50.

${ }^{199}$ Nicholls, From Dessalines to Duvalier, 76-77.
} 
nègre had applied to black slaves, and negres libres signified slaves who had gained their freedom prior to the revolution, as former negres libres established themselves as the black elite, they increasingly came to refer to themselves as noirs. The designation nègre would continue to apply to those who remained agricultural laborers. The Army of Sufferers "combined a critique of hierarchical divisions of color, class, and status within a discourse of egalitarian citizenship...The careful distinction made between noir and nègre in the political discourses of the period indicate that this was a matter of more than color alone. ${ }^{200}$ They would continue mobilizing against the landed elite, black or mulatto, when it became evident that they did not represent their interests.

While the use of the politique de doublure sometimes backfired on the milat elite, with the coming to power of Faustin Soulouque $(1847-59)$ as a prime example, it never meant democratization for the majority of Haitians, the peasantry. Thought to be rather unintelligent, and chosen to be yet another black figurehead president, Soulouque was able to wrest power from the mulatto elite who sought to control him in the name of the blacks. While Soulouque replaced mulatto military officers with black ones, placed prominent members of the black elite like Salomon in his government, and utilized state power to wrest economic power from the traditional mulatto elite, he rejected the notion of the democratic participation of the masses altogether. Initially allied with the peasant armies of the South, the piquets, against the mulatto elite, he eventually sought to suppress them ${ }^{201}$ as they demanded greater land redistribution. ${ }^{202}$ Where segments of the

\footnotetext{
${ }^{200}$ Sheller, "The Army of Sufferers," 48-49.

${ }^{201}$ Nicholls, "Rural Protest and Peasant Revolt," 188.

${ }^{202}$ John E. Baur, "Faustin Soulouque, Emperor of Haiti His Character and His Reign," The Americas 6, no.
} 
impoverished majority were included in the regime's activities, it was primarily in repressing potential rivals within the mulatto and black elites as members of his paramilitary group, the zinglins. With all centers of potential resistance repressed, Soulouque proclaimed himself Emperor Faustin I. ${ }^{203}$

The failure to maintain a progressive agenda, first with the tacit alliance between the liberal faction of the elite and the peasant population, then between the black elite and the peasantry, produced the context for the emergence of a Soulouque. "This was not the triumph of blacks over mulattoes, but the triumph of statist autocracy over the potentially democratic alliance of radical segments of the elite, the black small land-owning class, and republican peasants and cultivators." ${ }^{204}$ As a result of these failures, the armed peasant bands largely devolved into roving mercenaries. This lack of clear political orientation became apparent as subsequent Haitian governments faced the constant threat of ouster by piquets from the South, and what became known as cacos from the north, led by dissident generals who hoped to capture the state to enrich themselves and their clique. $^{205}$

Though unable to take control of the state apparatus to direct it towards their interests, the peasant masses were able to resist efforts by Haiti's nineteenth century elites to force them back onto the plantations. Rejecting abstract legal notions of freedom, "the Haitian insurrectionists laid the groundwork for a peasant society with the most evenly

\footnotetext{
2 (October 1949): 137.

${ }^{203}$ Nicholls, "Rural Protest and Peasant Revolt," 187-188.

${ }^{204}$ Sheller, "The Army of Sufferers," 49-50.

${ }^{205}$ Nicholls, "Rural Protest and Peasant Revolt," 190.
} 
distributed land ownership of any former plantation region of the Americas."206 Confronted with the choice of selling their labor to large landowners for wages, or working their own lands independently, time and again the peasantry chose the latter. "It clung to its control of the labor process and refused to be regimented by the landlords."

\section{GRANDONS, MILATS, AND OCCUPATION}

Unable to maintain control over peasant labor directly, the military elite largely abandoned the large-scale plantation economy of the colonial period, developing into two distinct economic groupings, largely paralleling the earlier divide between anciens libres (old freemen), the mulattoes, and negres libres (free blacks), the elite blacks. Most of the negres libres remained attached to the land, developing into a mostly black large landowning class that came to be known as the grandons (great dons), while the anciens libres evolved into a mostly mulatto urban merchant class, known as the milat bourgeois. ${ }^{208} / 209$ The grandons were mostly the descendants of the dark-skinned officers who had ascended in the military ranks under Toussaint, Dessalines, and Christophe, ${ }^{210}$ while the bourgeois were the offspring of the lighter-skinned, French-speaking, and often European-educated landlords, who were better able to build relationships with foreign

\footnotetext{
${ }^{206}$ Gonzalez, "The War on Sugar," 3.

${ }^{207}$ Michel-Rolph Trouillot, Haiti, State Against Nation: The Origins and Legacy of Duvalierism (New York: Monthly Review Press, 1990), 73-74.

${ }^{208}$ Catherine Orenstein, "An Interview with Ben Dupuy, Aristide's Ambassador-at-Large, 1993," in A Haiti Anthology: Libète (Princeton, NJ: Markus Wiener Publishers, 1999), 72.

209 Alex Dupuy, "Conceptualizing the Duvalier Dictatorship," Latin American Perspectives 15, no. 4 (1988): 106.

${ }^{210}$ Trouillot, Haiti, State Against Nation, 76.
} 
merchants, cementing a dominant position within Haiti's retail and wholesale trade. ${ }^{211}$

Nonetheless, both the grandons and the urban merchant class relied on the exploitation of the peasantry for their wellbeing. While the grandons accumulated their wealth and power by extracting "surplus value from peasants through a form of semi-feudal sharecropping called the two-halves system or dèmwatye,"212 the merchant class has historically controlled the import-export sector, ${ }^{213}$ where it redistributed wealth upwards through a number of taxes on peasant agricultural goods in the urban markets and customhouses, and on imported goods necessary for the peasantry to subsist, from flour and oil, to candles, kerosene, and matches. ${ }^{214}$

Throughout this historic conflict between Haiti's landowning and merchant elites, the militarized control of the peasant population has always remained a central concern. This is particularly embodied in the one institution to survive elite efforts to sustain the plantation economy after the colonial period, the rural police known as the chef de section. Haitian state-building has always required an alliance between the central government and the commandants of the country's various regional militias. These regional military commanders, though chosen by the holder of state power, were often members of the local grandon elite, and thus critical power brokers. A commandant

\footnotetext{
${ }^{211}$ Ibid., 75.

${ }^{212}$ Kim Ives, "A Class Analysis of Baby Doc: Mothballed Playboy Dictator Recalled to Service," Haïti Liberté 4, no. 27 (January 19-25, 2011), http://www.haiti-liberte.com/archives/volume427/A\%20Class\%20Analysis\%20of\%20Baby\%20Doc.asp.

${ }^{213}$ Stan Goff, "Class and Complexity in Haiti," Feral Scholar, http:/www.feralscholar.org/blog/index.php/2005/04/26/comparing-coups-haiti-venezuela-part-2/.

${ }^{214}$ Michel-Rolph Trouillot, "Haiti's Nightmare and the Lessons of History, 1994" in A Haiti Anthology: Libète (Princeton, NJ: Markus Wiener Publishers, 1999), 55.
} 
would in turn appoint a prominent peasant as chef de section in each rural section under his jurisdiction. This represented a nominal alliance between the central government and the country's numerous regional and local elites. ${ }^{215}$ The chef de section's primary role, as a member of the Armed Forces, was to maintain order in their rural section. "For the immense majority, he was the sole visible government functionary; in effect he was the government." ${ }^{216}$ As the only link between the rural communities and the central government, the chef de section had the final word in all important local questions. ${ }^{217} \mathrm{He}$ acted as the "justice of the peace, district attorney, notary, land surveyor, and agent of the army. In other words, the sheriff makes the law, implements the law, and interprets the law."218

Worse yet, the system of rural policing was built on the accepted exploitation of the peasantry. Not only did rural section chiefs serve as unpaid government agents, ${ }^{219}$ in fact, they paid the military for their positions. Their assistants, who often numbered in the hundreds, paid them in turn. The real compensation was what they could extort from the local population. ${ }^{220}$ Thus, payment served as an investment for the opportunity to exploit the populations under their jurisdictions. Most "earned their income by collecting various

\footnotetext{
${ }^{215}$ Jean L. Comhaire, "The Haitian 'Chef de Section,"' American Anthropologist 57, no. 3 (1955): 622.

${ }^{216}$ Bryant C. Freeman, "Tèt Kole Ti Peyizan Ayisyen: The Rural Police," Occasional Paper 18 (1998): v, Institute of Haitian Studies University of Kansas, https://kuscholarworks.ku.edu/bitstream/handle/1808/10909/ihsku_opn018_1998.pdf?sequence=1.

${ }^{217}$ Mats Lundahl, Politics or Markets? Essays on Haitian Underdevelopment (London: Routledge, 2002).

${ }^{218}$ Freeman, "Tèt Kole Ti Peyizan," 2.

${ }^{219}$ Alex Dupuy, Haiti in the World Economy: Class, Race, and Underdevelopment Since 1700 (Boulder, Colorado: Westview, 1989), 104.

${ }^{220}$ Freeman, "Tèt Kole Ti Peyizan," v.
} 
fees from the peasants which they divided among themselves and the state." ${ }^{221}$ The chef de section also served as an agent of the large landowners, ${ }^{222}$ while also performing surveillance functions for the Haitian state. The chef de section executed orders sent down from the region's commanding officer to stifle any political mobilization of the peasant population, with the collaboration of the local prefect, magistrate, and justice of the peace. ${ }^{223}$ With nearly 565 section chiefs throughout Haiti, one for each rural section, ${ }^{224}$ the peasantry lived under what amounted to a veritable police state.

Despite their collaboration in suppressing autonomous peasant mobilization for structural change, the two factions of the elite were often divided in terms of their particular economic interests. As the merchant class sought to purchase crops for export from the grandons at the lowest prices possible, and large landowners sought to keep prices high, conflict often ensued. These tensions were further exacerbated by the merchant class's relentless efforts to increase foreign investment in Haiti, a prospect that always inflamed the nationalist sentiments of the large landowning elite. ${ }^{225}$ While the grandons were never able to gain full control over the Haitian state because their power was fragmented across the particular regions where they held land and could organize peasant laborers into regional armies, the merchant class's dependence on the standing army meant that its power was also tenuous. As a means of black mobility, the Haitian

\footnotetext{
${ }^{221}$ Dupuy, Haiti in the World Economy, 104.

${ }^{222}$ Freeman, "Tèt Kole Ti Peyizan," 2.

${ }^{223}$ Ibid., 8 .

${ }^{224}$ Ibid., iv.

${ }^{225}$ Goff, "Class and Complexity in Haiti," Feral Scholar.
} 
army was never an institution under the direct control of the mulatto merchant elite. In Haiti, the bourgeoisie never conquered the 'right' to rule, but always had to 'negotiate' this 'right' through an intermediary," in government and the spoils therein, allowed the bourgeoisie to maintain its dominance over the private sector. Nevertheless, the stability of such an arrangement was always fragile. The nearly 30 or so coups d'état's in Haitian history are principally the result of this rivalry. "The grandon often organized rural militias which would run bourgeois presidents out of the capital, and the bourgeoisie often ousted grandon presidents with the standing city-based Army."227

As Haitian presidents aligned with the bourgeoisie sought to attract American investors to reestablish plantation agriculture in Haiti, the number, frequency, and intensity of caco insurrections against the capital increased significantly, eventually prompting a U.S. response. In 1911, president Antoine Simon was ousted by strong resistance in the agriculturally rich Artibonite and Northern Department regions ${ }^{228}$ as a result of a concession to American James P. McDonald that gave his corporation the right to build a railroad line across the region, to grow fig bananas on 12 miles of land on either side of tracks, and a monopoly over the crop's export. The political upheaval led to the eventual revocation of the banana concession, crippling the railroad project entirely. ${ }^{229}$ Future American interests would make it clear that investments in Haiti would

\footnotetext{
${ }^{226}$ Dupuy, "Conceptualizing the Duvalier Dictatorship," 106.

${ }^{227}$ Ives, "A Class Analysis of Baby Doc," 2012.

${ }^{228}$ Rubens François Titus, Roadmap to Haiti's Next Revolution: A Plan for Diaspora Haitians to Contribute to a Peaceful Turnaround (iUniverse Com, 2012), 10.

${ }^{229}$ Hans Schmidt, The United States Occupation of Haiti, 1915-1934 (New Brunswick, N.J.: Rutgers
} 
only follow direct U.S. control of the country. ${ }^{230}$ It was the public lynching of pro-U.S. president Guillaume Sam in 1915 and the growing influence of anti-U.S. political figures like Rosalvo Bobo that prompted the 19-year U.S. occupation of Haiti.

With the U.S. deciding to set the affairs of its unruly neighbor straight, a primary agenda for the occupation was to open the country to American investment, particularly in agriculture. "In 1921 a State Department officer prophesied that the fantastic prosperity of French-colonial Saint Domingue could be re-created under American auspices..."231 For American investors, Haiti was a place with seemingly "abundant and untapped land and labor." ${ }^{232}$ What was missing was "initiative and industry."233 But before Americans would invest in civilizing the Haitian countryside, they would have to first establish ownership of the land. This would require overturning Dessalines' law against foreign ownership of Haitian land that remained an integral part of every Haitian constitution since $1805 .{ }^{234}$ As the 1917 Haitian National Assembly refused to ratify the American-sponsored constitution removing the law against foreign ownership of land, it was subsequently dissolved by the Marine-created Haitian Gendarmerie. Concerned that new elections would produce another hostile National Assembly, the occupation forces would push through the constitution the following year using an extralegal plebiscite

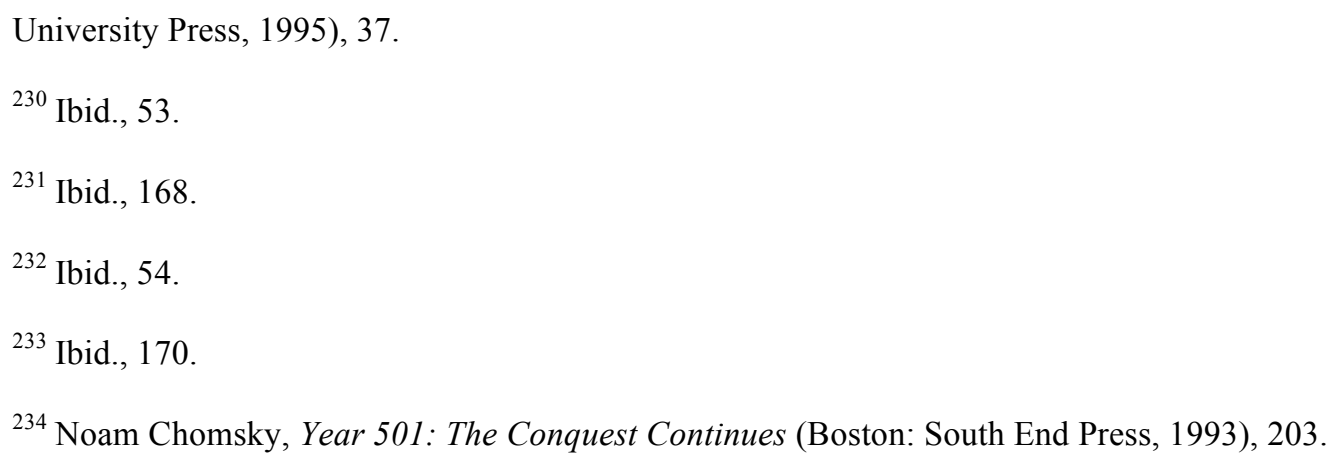


closely supervised by the Gendarmerie. With less than 5 percent of the population participating, and the Gendarmerie ordered to arrest anyone who publicly opposed the constitution, 98,225 voted in favor, with only 768 opposed. ${ }^{235}$ A string of presidents from the mulatto elite (Philippe Sudré Dartiguenave, Louis Borno, and Louis Eugène Roy) would collaborate in the effort to open Haiti to U.S. investment, simultaneously increasing the influence of their class.

Modern technology, irrigation, skilled management of production, efficient marketing, all required that the system of land-tenure where each peasant owned and farmed his little plot of land be destroyed. ${ }^{236}$ According to Financial Adviser Arthur C. Millspaugh, rural Haitians had to be transformed from being the contented, indolent, and shiftless peasants that they were, "if they [were] to be citizens of an independent selfgoverning nation." ${ }^{237}$ This would only be possible through working on foreign-owned plantations for wages. Moreover, the occupation forces believed that the indigenous traditions of labor exploitation would facilitate this transition. Typically Haitian laborers were paid 20 cents for a twelve-hour workday, far less than anywhere else in the Americas. "The greatest asset Haiti has is cheap labor....",238 In fact, the largest employer of local labor at the time, the Haitian American Sugar Company (HASCO), simply integrated its profit-making enterprise into the traditional system of rural

\footnotetext{
${ }^{235}$ Schmidt, The United States Occupation of Haiti, 98-99.

${ }^{236}$ Chomsky, Year 501, 204; Schmidt, The United States Occupation of Haiti, 11; Schmidt, The United States Occupation of Haiti, 178.

${ }^{237}$ Ibid., 158.

${ }^{238}$ Ibid., 170.
} 
repression by "sub-hiring workers through native gang bosses." 239 American promises of prosperity and progress would be wrought through the exploitation of the Haitian peasantry, just as had always occurred.

As U.S. occupation forces pushed through the Constitution of 1918, overturning the ban on foreign ownership of land, various high-level officers of the occupation sought to carve out pieces of Haiti for themselves. Assistant Secretary of the Navy, Franklin D. Roosevelt, investigated possibilities for investment throughout the country, particularly on the islands of La Gonave, La Tortue, and Ile a Vache. ${ }^{240}$ Dr. George F. Freeman, Director of the Agricultural Extension and Teaching Service (the Service Technique) established by the occupation in 1923, sought to imitate the plantation agriculture he witnessed in Indonesia, eventually interesting the U.S. government in selecting Haiti as a site for developing "a rubber supply in its own sphere of influence."241 Firestone and Goodrich would explore the possibility throughout the 1920s. The country's proximity to the U.S., the possibility of pushing "squatters" off of old colonial plantation land, and a seemingly abundant and pliant peasant population that could serve as workers on rubber estates proved rather enticing. Dr. W.W. Cumberland, the occupation's financial advisor to the Haitian government, set plans for sisal production, of particular interest to the U.S.

\footnotetext{
${ }^{239}$ Ibid., 178.

${ }^{240}$ Ibid., 111.

${ }^{241}$ Ibid., 177.
} 
Navy, which found the plant's fibers useful for products like rope and twine. ${ }^{242}$ Similar inquiries were made into "pineapples, bananas, cotton, and other products." 243

These investments were made possible through the active displacement of the peasantry. Even after the abolition of the law forbidding foreign tenure, the problem of accumulating enough land to plant efficiently plagued efforts to establish corporate plantation agriculture. The proliferation of peasant small-holders throughout Haiti stood in the way. In 1928, HASCO would launch a cadastral survey of agriculturally rich areas of the country using aerial photography as a pretext to engage in the mass eviction of peasants without land titles. In 1930, the Union Nationaliste accused the HaitianAmerican Development Corporation of destroying the homes and crops of the peasantry in the regions where sisal competed with them for acreage. ${ }^{244}$ They argued that the Haitian government, in collusion with the occupation forces, used the pretext of nonpayment of rent to the state to remove families that had subsisted on their land since the $19^{\text {th }}$ century. ${ }^{245}$ The concern was never payment, but rather land expropriation.

Beyond outright land expropriations, the occupation fundamentally disrupted life in the countryside. Alongside widespread rape and arbitrary killings, the occupation forces revived Haiti's $19^{\text {th }}$ century system of forced labor known as the corvée to expand

\footnotetext{
${ }^{242}$ Ibid., 176.

${ }^{243}$ Ibid., 177.

${ }^{244}$ Brenda Gayle Plummer, Haiti and the United States: The Psychological Moment (Athens: University of Georgia Press, 1992), 114.

${ }^{245}$ Matthew Casey, "From Haiti to Cuba and Back: Haitians' Experiences of Migration, Labor, and Return, 1900-1940," Ph.D. Dissertation, University of Pittsburgh, Pennsylvania, 2012, D-Scholarship, 85.
} 
the country's road network, allowing them to better administer the military occupation. ${ }^{246}$ For many, the corvée invoked the historical memory of colonial slavery, leading to a cacos rebellion amongst the northern peasantry under the leadership of former officers of Haiti's dismantled military, Charlemagne Peralte and Benoit Battraville. ${ }^{247}$ Though armed peasant resistance would eventually be neutralized for the most part by the Marines and the Gendarmerie by 1920, the threat of cacos insurrection ended the official use of the corvée. Nevertheless, many simply left the countryside, ${ }^{248}$ either for the country's urban centers or to become cheap and pliant labor in American-owned sugar plantations in Cuba and the Dominican Republic.

While the occupation would come to an end in 1934, displacement of Haitian peasants in order to expand plantation agriculture would not. WWII would serve as a period of further expansion for plantation agriculture, particularly rubber cultivation. Between 1939 and 1941, Haitian President Sténio Vincent agreed to a long-term program for the development of Haitian agriculture with the U.S. Department of Agriculture (USDA). The following year, Élie Lescot, a member of the mulatto elite with close ties to U.S. economic interests, succeeded Vincent as President of Haiti and establish the Société Haïtiano-Américaine de Développement Agricole (SHADA) Corporation. While owned exclusively by the Haitian government, it was financed by a five-million-dollar U.S. Export-Import Bank loan. The company was granted a 50-year lease on 150,000 acres of land, and a monopoly on the sale and export of natural rubber from Haiti. As the

\footnotetext{
${ }^{246}$ Laurent Dubois, Haiti: The Aftershocks of History (New York: Metropolitan Books, 2012).

${ }^{247}$ Paquin, The Haitians, 62.

${ }^{248}$ Dubois, Haiti: The Aftershocks of History, 2012.
} 
Japanese cut the U.S. from its source of rubber in Southeast Asia, Haiti became an important alternative. By 1943, 47,177 acres were cleared for the cultivation of cryptostegia, ${ }^{249}$ "a latex producing plant that would help ease the rubber shortage." 250 SHADA plantations would rely on security forces of fifty to sixty members of the Gard $d^{\prime} H a i t i$, the outgrowth of the occupation period's Gendarmerie. ${ }^{251}$

Initially celebrated as a shining example of Pan-American cooperation and "a step forward in the modernization of Haitian agriculture," ${ }^{252}$ its actual impact on the Haitian countryside would be particularly devastating. In declaring the most arable lands strategic zones for the cultivation of rubber and sisal, Lescot's government supported the mass removal of peasant families from their lands. ${ }^{253}$ As synthetic rubbers emerged, yields suffered due to drought conditions, and WWII came to an end, U.S. support for rubber cultivation ended. ${ }^{254}$ With massive unemployment following the demise of SHADA, as well as continued drought conditions, living standards for Haiti's rural and urban poor deteriorated significantly. As the black middle class grew in influence, claiming to represent the black rural and urban poor, Lescot would eventually be deposed in what became the Revolution of 1946.

\footnotetext{
${ }^{249}$ Matthew J. Smith, Red and Black in Haiti: Radicalism, Conflict, and Political Change, 1934-1957 (Chapel Hill: University of North Carolina Press, 2009), 44.

${ }^{250}$ Plummer, Haiti and the United States, 145.

${ }^{251}$ Ibid.

${ }^{252}$ Smith, Red and Black in Haiti, 44.

${ }^{253}$ Plummer, Haiti and the United States, 145.

${ }^{254}$ Smith, Red and Black in Haiti, 46.
} 


\section{THE REVOLUTIONS OF '46 AND '56}

The Lescot presidency represented the last vestiges of mulatto elite hegemony that had been sustained by the U.S. occupation. Some members of this group "supported the Americans, seeing the invasion as a short-term intervention which would re-establish order and refurbish their own position as the governing elite..." ${ }^{255}$ Unlike Stenio Vincent, a nominal member of the mulatto elite able to recognize the growing influence of the black middle class, thus including them in his government, Lescot took the opposite tact. He pursued a policy of mulatrification, whereby the sons of the mulatto elite occupied all the upper echelons of the military, the diplomatic corps, the civil service, and the cabinet, ${ }^{256}$ harkening back to the preferential treatment they received during the occupation. Alongside the exclusion of the black middle class, the Lescot regime provided tacit support for the Roman Catholic Church's 1941-42 anti-superstition campaigns against Vodou, the religion of Haiti's peasant majority. Some contend that the campaign was a means for the mulatto elite to restrain the growing noiriste opposition, ${ }^{257}$ which came to challenge its cultural, social, and political hegemony. It has also been associated with the expropriation of peasant land on behalf of American interests. ${ }^{258}$

Reactions against the racism of the occupation and associated mulatto hegemony were first manifested in the emergence of the Ethnology movement. Black intellectuals of the movement such as Justin Dorsainvil, Dr. Arthur Holly, and Jean Price Mars,

\footnotetext{
${ }^{255}$ Nicholls, From Dessalines to Duvalier, 177.

${ }^{256}$ Ibid., 167.

${ }^{257}$ Ibid., 183.

${ }^{258}$ Ibid., 204.
} 
emphasized the essential African roots of the Haitian people and their culture. They vehemently rejected the notion perpetuated by the Haitian elite that the "black African slaves of Saint Domingue had simply perished on the plantations without posterity," and that Haiti was "a cultural colony of France." ${ }^{259}$ Instead, much of the customs and traditions of the black African slaves had been preserved throughout Haiti's countryside amongst the peasantry. As Haitians suffered under the thumb of U.S. imperialism, the Ethnologists called for a return to the traditional values of their revolutionary ancestors, which survived in the Haitian countryside: their oral traditions and language (créole); their religion (Vodou); and their mode of production (peasant agriculture). Along with advocating for the use of créole in education, and broader acceptance of Vodou, they called for providing peasant farmers with access to more land, and for the development of technical and agricultural schools, along with regional development banks. ${ }^{260}$

This cultural reaction to the occupation would turn into political currency in the post-occupation period. While the Ethnologists talked about the significant gulf that existed between the numerically small French-educated elite, and the mass of impoverished, illiterate peasants, they also pointed to the black middle class as the potential catalysts for Haiti's social evolution. ${ }^{261}$ It was thought that they could provide the leadership necessary to improve the condition of the country's poor black majority. The potential for such a reality would emerge with the Revolution of 1946.

\footnotetext{
${ }^{259}$ Ibid., 153, 156.

${ }^{260}$ Ibid., 154-55.

${ }^{261}$ Ibid., 152.
} 
The ouster of Lescot in 1946 opened the door for mass politics as never before. "The elections of May the $15^{\text {th }} 1946$ gave birth to a new generation of politicians and a new crop of statesmen..."262 Socialists, labor unionists, and black nationalists (noiristes), competed over who would mobilize the masses for change, as well as the nature and direction of such change. At the center of this emerging mass politics was the black middle class that grew out of the U.S. occupation. While mulatto politicians of the traditional elite had little chance of winning power through elections, considering the politics of the period was largely a reaction against the mulatto hegemony of the Lescot period, they searched for a black proxy. Nevertheless, the new Congress elected the first black president in thirty years from their own class, Dumarsais Estimé, independent of the traditional elite. ${ }^{263}$

Despite strong support amongst the most aggressive elements of the noiriste movement, Estimé sought to pursue a middling position between the rising black middle class and the mulatto elite. Having represented the Artibonite in the legislative assembly, and serving in the Stenio Vincent government, Estimé received support from the black elite and middle class from the provinces, while also remaining open to the old mulatto elite. ${ }^{264}$ In order to mitigate opposition amongst the urban poor and working class, Estimé included their most powerful advocate, Daniel Fignolé, into his government. ${ }^{265} \mathrm{He}$ would go on to push forward a number of progressive initiatives, including the establishment of

\footnotetext{
${ }^{262}$ Paquin, The Haitians, 87-88.

${ }^{263}$ Ibid., 90-92.

${ }^{264}$ Nicholls, From Dessalines to Duvalier, 186.

${ }^{265}$ Ibid., 189.
} 
a minimum wage, the facilitation of industrialization, urban reconstruction, and improvement of the water supply in urban centers, as well as irrigation schemes, hydroelectric power, maternity and child welfare, and the construction of new schools in rural areas. $^{266}$

Though considered more-or-less a progressive defender of the black masses, in reality, Estimé's election in 1946 signaled the shifting nature of class power in Haiti, with his regime representing the upward mobility of the black middle class. The most vocal voices of this reality were the noiristes, the black nationalists who used the notion of "the greatest good for the greatest number" to secure their dominant position politically and economically in the name of the black masses. They used their access to the state to challenge the economic hegemony that the mulatto elite and U.S. corporations held over the country. In 1947, the Estimé government wrestled control of the banana industry from the Standard Fruit Company, passing legislation establishing a state monopoly over the parceling and distribution of bananas, with banana concessions distributed to six companies owned and operated by his political allies. A year later, similar state monopolies would be established over tobacco. ${ }^{267}$

Rather than serve as an opportunity to strengthen the political and economic relationship between the black middle class and the peasantry, these concessions were poorly managed, paying peasants reduced rates for their produce, making little effort to offer peasant farmers incentives such as insecticides and fertilizers. "Benefiting only the local companies that exploited the unchecked system of state patronage, the project was

\footnotetext{
${ }^{266}$ Ibid., 200.

${ }^{267}$ Smith, Red and Black in Haiti, 116.
} 
an unmitigated disaster from which the regime would never recover." ${ }^{268}$ Nationalism had simply been a means to empower and enrich the black elite and middle classes.

Other instances belied the government's genuine representation of the interests of the black masses. As the U.S. occupation displaced large numbers of peasants, and economic activity became increasingly concentrated in Port-au-Prince, the city's population expanded exponentially, creating a base for labor organizing. While the first embers of the labor movement in the aftermath of the U.S. occupation were thoroughly suppressed by the Vincent and Lescot government's, they would reemerge in the same political vacuum that brought the black middle class to power after Lescot's 1946 ouster. Labor was similarly attracted to noirisme, which called for the empowerment of a political class to represent the black majority, and thus looked to the black middle class for leadership. ${ }^{269}$ This led to a tentative alliance between working class movements and the noiristes. The populist figure, Daniel Fignolé, would emerge as the voice of Port-auPrince's urban poor, making him a threat to all the governments of the era, from Lescot to François Duvalier. In 1947, Fignolé would form the Mouvement Ouvrier Paysan (MOP), the Worker Peasant Movement, heading a federation of 29 unions by $1949 .^{270}$

Though Estimé initially included Fignolé in his government, and even encouraged some level of trade unionism, this was done more as a means to co-opt and mute their demands and autonomous mobilization. According to noiriste supporters of the regime, "the mentality of the Haitian workers...is different from that of workers in advanced

\footnotetext{
${ }^{268}$ Ibid.

${ }^{269}$ Ibid., 61-62.

${ }^{270}$ Nicholls, From Dessalines to Duvalier, 218.
} 
industrial countries; they need to be guided and educated."271 As Fignolé pressured the government from within for substantive policy strengthening the position of labor, he would be removed from his post and MOP banned along with other independent unions. The truth is, the noiristes who came to represent the core of Estimé's government fundamentally rejected democracy as a legitimate form of government for "the Haitian temperament." Elections and democratic representation were described as "sordid tinsel designed to mislead the masses," perpetuating the continued colonization of Haitian society by foreign concepts and principles. ${ }^{272}$ Instead, the noiristes called for the reassertion of order and discipline under an authoritarian government composed of members of the black middle class, who were to rule in the interest of the black masses. $^{273}$

Despite Estimé's efforts not to antagonize or alienate the traditional mulatto elite and their supporters in the United States, the dominant position of noiristes within his government, and his initial willingness to court the urban poor and working class by including Fignolé in his administration, were viewed as particularly threatening. Both would turn to their ally in the military, General Paul Magloire of the traditional black elite, to depose Estimé in 1950, mimicking the politique de doublure of the 19th century. Magloire would receive support from leading mulatto businessmen, the army elite, the Catholic Church, and the United States. Nevertheless, the black middle class would not be denied its turn at the seat of power. In 1956, Magloire himself would be ousted by a

\footnotetext{
${ }^{271}$ Ibid., 200.

${ }^{272}$ Ibid., 169-172.

${ }^{273}$ Ibid., 167-168.
} 
section of the armed forces with close ties to the noiristes, who then supported the election of François Duvalier in 1957.

Duvalier claimed that he was elected to complete the revolution that Estimé had begun. For him, this meant completely subduing the traditional mulatto elite who stifled the rise of the black masses. He argued that the poverty of the black majority was a consequence of mulatto racism and exploitation throughout the country's history, increasing his support amongst the black middle class from which he hailed, the grandons, which had historically vied for power against the predominantly mulatto merchant class, and the poor black masses, who he promised to protect against mulatto predation.

Duvalier also used noiriste rhetoric to gain control over the institutions that safeguarded the interests of the mulatto merchant class and their Western patrons. "The Church, with its French hierarchy, its Breton seminary, its foreign (overwhelmingly French) clergy, represented a prime example of ecclesiastical colonialism,"274 and thus had to be placed under national authority. French bishops and archbishops, the entire Jesuit order, as well as prominent Protestant leaders, were all expelled. The foreign diplomatic corps was similarly under siege. "To demonstrate to Haitians that he was strong enough...to bully and harass foreign powers and their blanc ambassadors...he expelled more foreign chiefs of mission than had been expelled during the whole of Haiti’s history." ${ }^{, 275}$ Similar means were used to remove the international press and human

\footnotetext{
${ }^{274}$ Robert Debs Heinl and Nancy Gordon Heinl, Written in Blood: The Story of the Haitian People, 14921971 (Boston: Houghton Mifflin, 1978), 582.

${ }^{275}$ Ibid., 579.
} 
rights organizations. Duvalier's prime objective was to isolate Haitians who potentially posed a threat to the regime from their Western allies.

This was also true for the greatest threat to any Haitian president holding power, the Haitian Army. Prior to Duvalier's coming to power, the Garde d'Haiti had served the interests of the mulatto merchant class, who were proxies for U.S. economic interests. ${ }^{276}$ Though Duvalier was allowed to become president with the belief that he would be but a civilian puppet of the military, instead he systematically weakened the Haitian Armed forces. Duvalier either killed or forced into exile the top officers from the previous regime, replacing them with those close to him. He disconnected the Army from its U.S. benefactors by removing all Marine-trained officers, canceling pending U.S. officer training courses, and eventually closing the Academie Militaire in 1961. He randomly shuffled and cycled military officers, preventing them from developing independent bases of power, setting a clear precedent that Duvalier intended to sustain civilian supremacy over the military. Perhaps the most effective measure taken by Duvalier to counterbalance the military was his creation of a separate autonomous coercive apparatus, the Milice de Voluntaires de la Sécurité Nationale (Militia of National Security Volunteers or VSN), a civilian militia informally called the Tonton Machoutes.

While Duvalier's civilian militia neutralized a Haitian military that had historically guarded the economic and political interests of the merchant class and its American benefactors, for Haiti's poorest, not much had changed. "Noirisme, which hails the occupation of the highest political offices by blacks as the inevitable conquest of power by the poor masses, [was] nothing more than an ideology of an emerging class of

${ }^{276}$ Smith, Red and Black in Haiti, 152. 
black rulers in search of hegemony." ${ }^{277}$ Under Duvalier, Haiti's class structure did not undergo a radical qualitative transformation. The black middle class faction that took over the state apparatus simply established itself as the brokers through which the traditional merchant class would continue their control over certain segments of the economy. Duvalier "had no objection to the merchants prospering...But he insisted on the right to dictate the economic and social price that the merchants would pay for this domination, and he saw to it that the state's share of the spoils increased so as to fit current political realities...Similarly, if it valued its social domination, it would, at the very least, have to learn to share control of the social system with the nouveaux riches from the black middle classes. ${ }^{, 278}$ Duvalierisme did not represent an overturning of class relations. ${ }^{279}$ After the successful pacification of the mulatto bourgeoisie, those willing to cooperate with the regime were allowed to continue their dominance over the importexport sector.

With unchallenged control over the state established, François Duvalier was able to guard grandon interests for a time by forestalling attempts by U.S. capital to open Haiti's economy to investments in industrial agriculture and U.S. agricultural imports, and insuring that they were able to expropriate the land of small peasant landholders with impunity. ${ }^{280} \mathrm{He}$ was also able to expand access to the spoils of power, not only to the black middle class who came to occupy most of the appendages of the state, but also to

\footnotetext{
${ }^{277}$ Fatton, Haiti's Predatory Republic, 98.

${ }^{278}$ Trouillot, Haiti: State Against Nation, 206.

${ }^{279}$ Dupuy, Conceptualizing the Duvalier Dictatorship, 110.

${ }^{280}$ Coalition for Haitian Refugees, "No Greater Priority: Judicial Reform in Haiti, 1995," in A Haiti Anthology: Libète (Princeton, NJ: Markus Wiener Publishers, 1999), 67.
} 
the poorest Haitians willing to commit violence in the name of the regime, broadening his base in ways that had not existed before. ${ }^{281}$ Nowhere was this more evident than in Haiti's hinterlands.

When François Duvalier came to power, he made use of the chef de section system for his own agenda, strengthening what had been a historically tenuous tie. Not only was Duvalierist power politics extended into Haiti's rural areas, ${ }^{282}$ the grandon were also provided with an ideology which contended that Haiti's progress was only possible with an authentic representation of the black masses at the country's helm, someone who understood their rural and African cultural roots. With the establishment of the VSN and the tonton macoutes, Duvalier provided the black landed elite with a national presence they had never had before. Representing the Duvalierist state and the grandon, their "uniform - blue denim shirt, pants, and hat, with a red kerchief — evoked the traditional costume of the Vodoun god Zaka (the peasant god of agriculture), the colors of the Haitian national flag before Duvalier, and the peasant armies of the nineteenth century." 283 The iconography of the state was thus made to reflect the values of the Haitian countryside, while the institutions of the countryside were increasingly transformed into appendages of the state. This was particularly possible because Duvalier's "militia respected the local hierarchy to the extent that it tended to recruit major Vodoun priests, village big men, rich peasants...landowners and commanders,"284

\footnotetext{
${ }^{281}$ Dupuy, "Conceptualizing the Duvalier Dictatorship, 108.

${ }^{282}$ Lundahl, Politics or Markets, 2002.

${ }^{283}$ Trouillot, Haiti: State Against Nation, 191.

${ }^{284}$ Ibid.
} 
ensuring that the network of macoutes and section chiefs was thoroughly integrated. Often the chef de section was also a tonton macoute. ${ }^{285}$ The militia thus served as "local proof of state power...suggest[ing] to the community how far the arms of the state could reach, ${ }^{1286}$ while also reinforcing the authority of those who already ruled the countryside.

The VSN also created the illusion of "a significant popular mass of support for Duvalier's regime." ${ }^{287}$ It was one of few institutions that was readily recognizable throughout the country, and which every segment of the population could participate, no matter their class, age, or gender. Most importantly, it actively recruited the poor. "And many among the urban and rural poor joined...not just because it was a 'genuine [economic] elevation'...but also because for the first time they were becoming citizensacknowledged members of the nation." 288

An important development to note during François Duvalier's reign was the extension of this surveillance apparatus into Haiti's urban areas to deal with the threat that, not only the merchant elite and the traditional Armed Forces, posed to the regime, but also Port-au-Prince's growing urban poor. As migration from rural areas into the country's urban centers increased due to declining agricultural production and the lure of jobs in the burgeoning light manufacturing sector, so did the need for an apparatus of control increase in these same urban spaces. A new population of potential workers needed to be watched and disciplined. Having been mobilized by Fignolé's MOP

\footnotetext{
${ }^{285}$ Lundahl, Politics or Markets, 2002.

${ }^{286}$ Trouillot, Haiti: State Against Nation, 191.

${ }^{287}$ Fatton, Haiti's Predatory Republic, 107.

${ }^{288}$ Trouillot, Haiti: State Against Nation, 191.
} 
throughout the 1940s and 1950s into his infamous woulo konpresè (steam-roller), ${ }^{289}$ this population would be thoroughly suppressed during François Duvalier's rule, only to become politically mobilized again in 1986 after the demise of Jean-Claude Duvalier's government.

The emergence of Duvalierisme represented the failure of the 1946 Revolution and the Estimé regime it produced to bring the black middle-class, the peasantry, and the urban poor and working class together in a progressive coalition supporting broad-based democratic participation. Efforts by the mulatto elite to maintain its hegemonic position over the black middle-class by overthrowing the Estimé government served to radicalize the noiristes further. But the resurgence of the black middle class under Duvalier did not simply mark the suppression of the mulatto elite, but all sources of opposition, including the black peasantry and working class it claimed to represent. Thus, while Duvalierisme had the symbolic trappings of a mass movement, in reality, the domination of the urban and rural poor by the elite, or those aspiring towards elite status, did not fundamentally change.

\section{CONCLUSION}

The eventual breakdown of the Duvalier dictatorship had much to do with the Jean-Claude Duvalier government's growing estrangement from the base that his father had built domestically, symbolized by the reemergence of Haiti's traditional merchant bourgeoisie within the halls of power and growing U.S. economic and political influence over the country. The shift between the Francois and Jean-Claude regimes involved "the

\footnotetext{
${ }^{289}$ Gage Averill, A day for the hunter, a Day for the Prey: Popular Music and Power in Haiti (Chicago, Illinois: University of Chicago Press, 1997), 72.
} 
deepening of relations between the state and holders of capital at home and abroad....”290 Many of the institutions which once operated as checks on the Haitian presidential prior to Francois Duvalier's coming to power were allowed to reassert their traditional influences over Haitian politics, while the black middle class and its noiriste ideology were increasingly being displaced within the regime.

"Unlike the father, Jean-Claude Duvalier increased the power of the Army and decreased that of the traditional Tontons Macoutes. The son also abandoned the strident black nationalism of the father and forged an alliance with the mulatto bourgeoisie."291 His marriage to a nominal member of the mulatto business class, their ascendance within his regime, and the increasing lavishness of their corruption in the face of a declining standard of living, even for the grandons, further solidified in the minds of many black Haitians that Jean-Claude was not for them. As the U.S. pushed the regime to curtail the human rights violations committed by the tonton macoutes and increasingly invested in the power and professionalization of the military, "he gradually lost the support of many macoute leaders who, by the early 1980s proclaimed that they were unwilling to stick out their necks very far to defend the regime. ${ }^{292}$

This was compounded by increasing U.S. economic penetration of Haiti, and the emergence of a new element of the merchant class, the industrialists. As U.S. corporations experienced declining rates of profit due to increasing global competition and political pressure to provide American employees with a high standard of living, they

\footnotetext{
${ }^{290}$ Trouillot, Haiti: Sate Against Nation, 200.

${ }^{291}$ Dupuy, "Conceptualizing the Duvalier Dictatorship," 113.

${ }^{292}$ David Nicholls, "Haiti, the Rise and Fall of Duvalierism," Third World Quarterly 8, no. 4 (1986): 1248.
} 
sought to defray their operating costs through "a new form of industry, assembly industry, in which foreign capital could be imported into countries like Haiti, ${ }^{, 293}$ were the repressive state guaranteed lower labor costs. In order to attract more foreign capital, the segment of the merchant class connected to the assembly industry sought to curtail the corrupt practices of the Haitian state, and place technocratic economic managers like Marc Bazin within Jean-Claude's administration to further liberalize the Haitian economy. Both the traditional merchant class, who relied on monopolization of imports and exports to generate its wealth, and the black middle class, which secured its income through control of the state's various bureaucracies, would resist these reforms. ${ }^{294}$ As Jean-Claude vacillated between elite groupings, he inevitably alienated both.

With the economic liberalization of what came to be known as Jean-Claudisme exacerbating the rapid decline of peasant agriculture by allowing the unabated flooding of Haiti's market with cheap imported rice, the ranks of the urban slums swelled. Not only in Port-au-Prince, but throughout the provinces in cities like Gonaives, Cap Haitien, Jacmel, and Jeremie, reviving the spirit of what had once been Fignolé's woulo konpresè. ${ }^{295}$ As the regime fragmented between the new guard and the old guard, and its ability to utilize repression on the population was constrained by the international community's concerns with human rights, a mass movement uniting the increasingly desperate urban poor and peasantry emerged. It is in this political opening that a new vision for Haiti is espoused, evolving to become Lavalas.

\footnotetext{
${ }^{293}$ Catherine Orenstein, "An Interview with Ben Dupuy, Aristide's Ambassador-at-Large, 1993" in A Haiti Anthology: Libète (Princeton, NJ: Markus Wiener Publishers, 1999), 72.

${ }^{294}$ Ibid.

${ }^{295}$ Averill, A Day for the Hunter, 72.
} 


\section{CHAPTER III.}

\section{LAVALAS, THE FLOOD \\ INTRODUCTION}

What is a Lavalas in the literal sense? At once terrifying, and magnificent, a Lavalas is a torrential deluge that pours fourth from Haiti's mountains and hillsides during the rainy season onto surrounding communities, washing all in its path out to sea. It is cleansing through flood. The term Lavalas was first popularized in a 1987 Tét Ansanm (Heads Together) song declaring the resolve of the peasant movement to fight against the military violence directed at its activists during that year's elections. ${ }^{296}$ The chorus of the song, 'Yo pare pou nou/Nou pare pou yo, Mezanmi nou se lavalas/ N ap pote y ale' (They're preparing for us/ But we're prepared for them/ My friends, we're the deluge/ We'll wash them all away), was a declaration of the popular movement's strength in the face of Haiti's longstanding traditions of elite and military abuse against the country's moun andeyo. ${ }^{297}$

As one of the most vociferous voices challenging the repression and corruption of the dictatorships, even to the brink of death, Aristide came to represent the aspirations of Haiti's poorest, most marginalized, and most disenfranchised. According to many, it was through Aristide's election that the aspirations of Haiti's poor urban slum dwellers and rural peasants finally entered into the previously closed world of Port-au-Prince politics.

\footnotetext{
${ }^{296}$ Daniel Simidor, "25869: Simidor (Comment): Reuters Revisionism (Fwd)," Bob Corbett's Haiti List, http://www2.webster.edu/ corbetre/haiti-archive-new/msg26184.html.

${ }^{297}$ The term andeyò literally means 'outside'...Haiti's traditional urban dwellers, educated French speakers, disparagingly refer to the rest of the country as andeyò, and its residents, moun andeyò: [as] 'outsiders.' This captures the historic exclusion of peasant from Haitian society as defined by those who have traditionally managed political and economic affairs of the country from the Republic of Port-auPrince. Found in Mark Schuller and Pablo Morales (ed.), "Tectonic Shifts: Haiti Since the Earthquake" (Sterling, VA: Kumarian Press, 2012), 96.
} 
And thus he came to call the movement that brought him into power in 1991 Lavalas, in homage to the song that captured the essence of the broad-based struggle for democracy spearheaded by Haiti's poor. Aristide's slogan for the Lavalas movement, "'Yon sél nou féb, ansanm nou fó, ansanm ansanm nou se lavalas' (Alone we're weak, together we're strong, united we're a deluge)," came to represent and reinforce the spirit of solidarity that characterized this period in Haitian history. ${ }^{298}$

There are two ways one can choose to understand Lavalas. On the one hand, Lavalas can be reduced to the political apparatus that emerged around liberation theologian turned president, Jean-Bertrand Aristide. On the other, Lavalas provides an imagery of the broad-based grassroots movement that materialized prior to the fall of Jean-Claude Duvalier in 1986 and the fleeting retrenchment of Duvalierisme that followed. While these two interpretations of Lavalas are not the same, they cannot be treated as mutually exclusive. This chapter will present the factors that were pivotal to the rise of the Lavalas movement and the eventual election of Aristide during this critical juncture in Haitian history. The first section will outline how the increasing prominence of human rights as a central component of U.S. foreign policy during the 1970s significantly restrained the capacity of the Jean-Claude regime to use repression against the population, providing the social and political openings necessary for mass mobilization against the dictatorship. The next sections will present how important shifts within Haitian media and the Catholic Church occurring around the same time as the U.S.'s emphasis on human rights helped to foster a new social and political consciousness amongst Haiti’s urban poor and rural peasantry, generating a civil society

\footnotetext{
${ }^{298}$ Averill, A Day for the Hunter, 182.
} 
resurgence that would come to play an essential role in the eventual ouster of the JeanClaude dictatorship, and its successor, the military-led Conseil National de Gouvernement (CNG). The fourth section will address Ronald Reagan's reconceptualized of human rights within the narrow framework of democracy promotion, and how this, while contributing to the removal of Duvalier, also sought to restrict the boundaries of change sought by the newly emergent civil society. The final section of this chapter will discuss how the popular movement challenged currently dominant conceptions of civil society and democracy.

\section{THE HUMAN RIGHTS AGENDA}

Following the national disgraces of President Richard Nixon's Watergate scandal in 1974, the conclusion of the decades-long Vietnam War in 1975, and the 1975-76 Church Committee revelations showcasing CIA involvement in manipulating elections and plotting political assassinations around the world, the tenor of American politics fundamentally changed. "These events...shook the entrenched national myth that the United States had a unique heritage of morality and respect for human rights worldwide."299 Jimmy Carter's election in 1976 was framed as an effort to right the ship once again. He espoused a 'morality-in-politics' that promised a government that would be "honest, decent, open, fair, and compassionate." 300 One aspect of this effort to reestablish America's moral leadership in the world was the Carter administration's

\footnotetext{
${ }^{299}$ David Carleton, and Michael Stohl, "The Foreign Policy of Human Rights: Rhetoric and Reality from Jimmy Carter to Ronald Reagan," Human Rights Quarterly 7, no. 2 (May 1985): 206.

${ }^{300}$ Manoj K. Joshi, "The 'Human Rights Phase' of American Foreign Policy," Social Scientist, 10, no. 6 (June 1982): 38.
} 
supposed human rights agenda. As the Carter administration sought to make human rights a tool of U.S. foreign policy, the Jean-Claude regime, like many other governments throughout the Third World dependent on U.S. largess, became fundamentally restrained in its ability to use repression against the Haitian population, a development that provided social and political space for the emergence of the vibrant civil society that would later become Lavalas.

This new emphasis on human rights resulted in a number of institutional changes within the U.S. foreign policy apparatus. An independent Bureau for Human Rights and Humanitarian Affairs was created within the State Department. Embassies and ambassadors increasingly accounted for human rights conditions in their countries of operation. The Department of State was now legally required to submit reports to Congress regarding the status of human rights in countries that received U.S. economic or security assistance, which the U.S. used as leverage within international financial institutions. And, critically, the Assistant Secretary of State for Human Rights and Humanitarian Affairs was made a full member of all interagency committees approving security assistance and arms transfers. ${ }^{301}$ President Jimmy Carter's increasing use of the rhetoric of human rights was cited as a factor in making it a subject of national policy debate in many countries; a topic of focus in the discussions of international organizations; a subject in the world media; and increasingly, part of the popular consciousness across the globe. ${ }^{302}$

\footnotetext{
${ }^{301}$ Mark L. Schneider, "Human Rights Policy Under the Carter Administration," Law and Contemporary Problems 43, no. 2 (Spring 1979): 262-264.

${ }^{302}$ Schneider, "Human Rights Policy Under the Carter Administration," 266.
} 
The growing global emphasis on human right's had a significant impact on Haiti during this period. This was particular true due to the rapid opening of the country to foreign economic investment and aid that followed François "Papa Doc" Duvalier's death, and the succession of his 19 year-old son, Jean-Claude "Baby Doc" Duvalier, to power in 1971. The initial rapprochement between the United States and Haiti that began with the elder Duvalier's 1969 meeting with then, New York governor Nelson Rockefeller, ${ }^{303}$ turned into a growing dependency as Baby Doc embarked on what he came to call Jean-Claudisme.

Jean-Claudisme emerged in the wake of U.S. foreign policy establishment that increasingly utilized human rights rhetoric as leverage to force country's to carry out liberal economic reforms. So, he emphasized a reformed Duvalierisme that curtailed the most overt forms of repression while promoting limited economic and political liberalization as a means to attract international aid and foreign capital investment. Liberalization served to maintain the regime's favorable standing with the international community, ensuring the continued flow of resources that could then be distributed amongst a vast network of cronies.

From the start of his rule, Jean-Claude sought to present a decidedly different image of the regime than had his father. Upon Francois Duvalier's death, thousands of Haitians, along with nearly 100 foreign reporters, were allowed into the palace, a place "once regarded as something of an ogre's castle," as a sign of the regime's new openness. Jean-Claude subsequently ordered the arrest of three of Papa Doc's cruelest Tonton Macoute civilian militia leaders, a public step towards curbing the violent excesses of the

\footnotetext{
${ }^{303}$ Don Becker, "Rockefeller is Given Warm Haiti Welcome," The Times-News, July 2, 1969.
} 
past. And, in his first speech to the Legislative Assembly, he called for a national reconciliation with those exiled during his father's 14-year reign of terror, in an effort to "work towards a new Haiti, generous and progressive." ${ }^{304}$ Part of this new progressive Haiti included efforts to make substantial reforms to improve Haiti's tax system, reorganize its bureaucracy, and reduce corruption. ${ }^{305}$

This new face to Duvalierisme provided the international community with an opportunity to increase its economic ties with Haiti once again. Immediately, U.S. Ambassador Clinton E. Knox called for an increase in American aid to the new regime, aid that had been virtually cut off in 1962 by then President John F. Kennedy in response to the elder Duvalier's violent repression of political opposition. ${ }^{306}$ Soon after, a representative of the United States Agency for International Development returned for the first time since 1963 in hopes of renewing economic and technical assistance to the country. ${ }^{307}$ And the International Monetary Fund (IMF), the World Bank, and the InterAmerican Development Bank (IDB) of the Organization of American States began calling Haiti a place where "the climate for loans, grants, and investments had markedly improved. ${ }^{308}$ Between 1976 and 1977 alone, the Duvalier government received \$39

\footnotetext{
${ }^{304}$ Robert Evans, "The Heir Has His Work Cut Out For Him: Haiti," New York Times, May 2, 1971.

${ }^{305}$ Alan Riding, "Foreign Investments and Tourism Rise: Haitian Economy Beginning to Stir," New York Times, August 23, 1971.

${ }^{306}$ Homer Bigart, "U.S. Envoy Favors More Aid to Haiti: Urges \$750,000 Program for Farm Projects," New York Times, April 26, 1971.

${ }^{307}$ Riding, "Foreign Investments and Tourism Rise," The New York Times.

${ }^{308}$ Richard Severo, "In Haiti, Things On the Surface Seem the Same, but Many Changes are Emerging," New York Times, April 23, 1972.
} 
million in grants from the United States. ${ }^{309}$ By 1979, two-thirds of Haiti's budget, about $\$ 81$ million, came from the international community. Of this, 50 percent came from multilateral organizations such as the United Nations, the World Bank, and the InterAmerican Development Bank, supplemented by bilateral aid primarily from the US, and \$15 million more from non-governmental agencies. ${ }^{310}$ Along with this aid came rapid and substantial increases in "tourism and foreign investment"

This growing foreign economic activity, while increasing the wealth of those associated with the regime, also left Jean-Claude open to greater international criticism and control as he "mortgaged even further the autonomy which Francois Duvalier had so zealously guarded."312 Increased dependency on international aid led to demands that went beyond what the regime had initially prepared to concede. This became particularly evident with the 1976 election of Jimmy Carter and his emphasis on human rights.

As the Carter Administration prepared to take office, a House of Representatives' International Relations Committee report prepared by the State Department pointed to Haiti as one of six countries engaged in serious human rights violations in contrast to the outward facade presented by the Jean-Claudiste regime. ${ }^{313}$ Upon taking office, Carter criticized the amount of U.S. aid being given to Haiti, and on August 14, 1977, sent U.S. Ambassador to the United Nations, Andrew Young, to Haiti as part of a broader

\footnotetext{
309 "Young Lands in Haiti on $9^{\text {th }}$ Stop of Tour: To Stress Human Rights Concern-May Also Discuss More Aid” New York Times, August 15, 1977.

${ }^{310}$ Ferguson, Papa Doc, Baby Doc, $67-68$.

${ }^{311}$ Riding, "Foreign Investments and Tourism Rise," New York Times.

${ }^{312}$ Heinl, Written in Blood, 658.

${ }^{313}$ Joshi, "The 'Human Rights Phase,'" 42.
} 
Caribbean-wide trip to impress upon the Duvalier government the administration's concerns with its human rights record. ${ }^{314}$ These threats to withhold aid if further reforms weren't made prompted the Jean-Claude regime to act.

Jean-Claude would allow for a freer social and political climate to emerge in Haiti in order to maintain the flow of aid money that bought the regime continued support from the military, the traditional elite, and the nouveau rich that came to represent its inner circle. In 1977 he invited U.S. representatives and foreign journalists to witness the release of 104 political prisoners. In 1978, he ratified the Inter-American Convention on Human Rights, ${ }^{315}$ allowed more exiles to return to the country, drastically loosened press controls, even to the point of allowing open criticism of the regime's failings. In 1979, "to sate the appetite of the international community for [more] signs of 'progress' on the human rights front, ${ }^{316}$ the regime declared elections for the Unicameral National Assembly. Though only Duvalierists were allowed to run for nearly all posts, in Cap Haitien, schoolteacher and opposition candidate Alexandre Lerouge was allowed to run; to speak directly about the regime's corruption and failures to address the painful economic conditions faced by Haitians throughout the country; and eventually, to win. Lerouge would become the "first popularly elected opposition legislator under the Duvalier dictatorship," ${ }^{317}$ with 34,800 out of 37,200 total votes.

\footnotetext{
314 “Young lands in Haiti," New York Times, August 15, 1977.

315 Anne Greene, The Catholic Church in Haiti: Political and Social Change (East Lansing, Michican: Michigan State University Press, 1993), 193.

${ }^{316}$ Heinl, Written in Blood, 666.

317 "Haiti Vote Could Signal Start of a New Era," The Virgin Islands Daily News, March 3, 1979.
} 
Allowing Lerouge to win the seat was Jean-Claude's attempt to show some independence from the traditional hard-line Duvalierists, the "dinosaurs," who were wholly against the idea of political reform. ${ }^{318}$ These actions by the Duvalier regime provided the social and political openings necessary for a number of grassroots social and political movements to emerge within key sectors of Haitian society, while leaving the regime fragmented between the new reformist Duvalierists and the old-style "dinosaurs."

\section{CREOLE AND THE PUBLIC DISCOURSE}

As Baby Doc carried out his kindler-gentler version of Duvalierisme, fundamental changes were afoot throughout Haitian society. One of these changes was the role of the media in Haiti. In hopes of being seen internationally as "the president of Haiti who had irrevocably established democracy," Jean-Claude's 1971 constitution guaranteed the freedom of speech, ${ }^{319}$ prompting a resurgence of the independent press like never seen before in Haiti. Initially hesitant, the media would come to speak openly and critically about the country's politics and economics, ${ }^{320}$ a marked shift from the initial days of François Duvalier rule, when opposition newspapers were bombed by tonton macoutes, and publishers jailed and tortured. ${ }^{321}$ This media revolution of the early 1970 s fostered by the United States' growing support for human rights abroad was central to the rising

\footnotetext{
${ }^{318}$ Heinl, Written in Blood, 667.

${ }^{319}$ Carolyn Fowler, "The Rise and Fall of Haiti’s Press, The Christian Science Monitor, February 6, 1981. ${ }^{320}$ Ibid.

321 "‘The Haitian Flag and Revolution': Papa Doc was Power Personified," The Palm Beach Post, April $23^{\text {rd }} 1971$.
} 
political consciousness of Haiti's poor and their eventual entrance into Haitian politics as persons with agency.

While newspapers and independent journals galvanized students and intellectuals in Haiti's largest cities, the real revolution was in radio, where broadcasters increasingly spoke directly to Haiti's poor and illiterate peasants throughout the countryside. ${ }^{322}$ None were more influential than Jean Dominique at Radio Haiti; later Radio Haiti-Inter. ${ }^{323}$ Perhaps the radio station's greatest contribution to Haiti's struggle for democracy was its impact on the country's language of public discourse. While Haiti's traditional newspapers, its few radio stations, and its single television station provided news solely in French, the language of Haiti's elite, Radio Haiti was the first to begin presenting its news segments in Creole, the language of the Haitian masses. This fundamentally transformed the notion of who was legitimately allowed to partake in political discourse. Later, as the Jean-Claude regime began cracking down on independent media, forcing the closing of Radio Haiti and the exile of Jean-Dominique, the Catholic Church's Radio Soleil would come to serve a similar function. ${ }^{324}$

Despite being a country established through the revolution of African Creolespeaking slaves against French colonial rule, for much of its history, Haiti has maintained French as the official language of the country to the exclusion of Creole. This subordination of Creole to French is fundamentally "an expression of the concrete reality

\footnotetext{
${ }^{322}$ Nicholls, "Haiti: The Rise and Fall of Duvalierism," 1242.

${ }^{323}$ Michele Montas-Dominique, "The Role of the Press in Helping Create the Conditions of Democracy to Develop in Haiti," University of Miami Law Review 56, (2001-2002): 399.

${ }^{324}$ Greene, The Catholic Church in Haiti, 150.
} 
of the relations between dominant and subordinate classes within Haiti." ${ }^{, 325}$ It has meant that all official government business was conducted in French, from court proceedings to parliamentary debates; formal documents such as deeds, medical records, and building permits were written in French; even road signs and the names of public buildings. ${ }^{326}$ The country's main newspapers of record, Le Nouvelliste and Le Matin, along with Le Moniteur, which publishes all new laws and government decrees, were written in French. French was, and still is, the primary language of education. Students were taught and tested in French, and most textbooks were also in French. ${ }^{327}$ This was true in a country where all Haitians spoke and understood Creole, while perhaps only $5 \%$ or less spoke and understood French. ${ }^{328}$ This has had profound impacts for the possibility of democracy in Haiti.

The predominance of French in official circles to the neglect of the Creole understood by the majority of Haitians has created a society that is "sharply and conspicuously divided between the minority of people who can meaningfully participate in the official, French-driven world around them, and the majority, who can't." ${ }^{, 329}$ Though all Haitians, irrespective of class, are fluent in Creole; the capacity to operate in French dramatically declines the lower one happens to be on the class scale. While the wealthy

\footnotetext{
${ }^{325}$ Pierre-Michel Fontaine, "Language, Society, and Development: Dialectic of French and Creole Use in Haiti," Latin American Perspectives 8, no. 1 (1981): 44.

${ }^{326}$ Leon Neyfakh, "The Power of Creole," Boston.com, July 24, 2011, Accessed July 12, 2016, http://www.boston.com/news/education/k_12/articles/2011/07/24/the_power_of_creole/?page=full.

${ }^{327}$ Michel DeGraff, "Language Behavior," Boston.com, June 16, 2010, Accessed July 12, 2016, http://www.boston.com/bostonglobe/editorial_opinion/oped/articles/2010/06/16/language_barrier_in_haiti/.

${ }^{328}$ Ibid.

${ }^{329}$ Neyfakh, "The Power of Creole," Boston.com.
} 
elite are typically quite fluent in French, having attended the best Catholic Schools in Haiti, which specialize in educating the elite in the necessary French cultural and social mores needed to attain power in Haiti, the working class, the urban poor, and the peasantry often have little to no knowledge of the language. "Language is thus a cultural manifestation of the class struggle, and fluency in French is a weapon of the traditional bourgeoisie." 330

Haitian society is fundamentally structured around the belief that "the people who are important in society know and speak French."331 Those who can only speak Creole are politically, economically, socially, and culturally marginalized. ${ }^{332}$ They are the moun andeyo, a term literally meaning "the outside people," used by the traditional Frenchspeaking urban elite to describe the black Creole-speaking peasants, and increasingly, the urban poor. ${ }^{333}$ French was a tool to not only exclude the poor from important political and economic processes, but also to ideologically justify such exclusion. While it meant that the majority of Haitians could not read the laws, decrees, and other proclamations, or understand the speeches of presidents and other politicians, ${ }^{334}$ it also meant that one was seen as illiterate, of low socioeconomic status, and generally, backwards, and thus, necessarily excluded from the important affairs of state. The maintenance of French as the language of public affairs, particularly political affairs, was a means to legitimize the

\footnotetext{
${ }^{330}$ Fontaine, "Language, Society, and Development," 34.

${ }^{331}$ Neyfakh, "The Power of Creole," Boston.com.

${ }^{332}$ Fontaine, "Language, Society, and Development," 31.

${ }^{333}$ Schuller and Morales, Tectonic Shifts, 96.

${ }^{334}$ Fontaine, "Language, Society, and Development," $31-32$.
} 
privileged position of the dominant French-speaking elite over the Creole-speaking poor. ${ }^{335}$

During the 1970s, and 1980s, Haiti's mass media fundamentally challenged this exclusion. Radio Haiti, and later, Radio Soleil's use of Creole was central in the development of a true public sphere in Haiti. "To reach a democratic stage...it is argued that a public sphere must be created"... a space for citizen's to exchange information and engage in debate. ${ }^{336}$ This could not happen within a context where society's primary institutions operated using a language that remained foreign to the vast majority of society's members. Affirmation of Creole's value in the public sphere implied "a rejection of the value system, and the social, political, and economic structures of the neocolonialist order" ${ }^{337}$ that had been sustained by the Haitian elite.

Creole, "decidedly African in its structure and rhythm, but characteristically European in its lexical dynamics, ${ }^{, 338}$ has always been the language around which the Haitian masses organized against elite rule, elites who often justified their right to rule on their ability to speak French and emulate French mores. For the varied African peoples and cultures that commingled on Saint Domingue's sugar and coffee plantations, Creole facilitated the sociopolitical consciousness necessary for revolt against the institutions of slavery and colonization. "Creole...provided a common linguistic framework for communication among slaves" who, "by the eve of the revolution, acquired an essential

\footnotetext{
${ }^{335}$ Ibid., 37.

${ }^{336}$ Leara Rhodes, Democracy and the Role of the Haitian Media (Lewiston : E. Mellen Press, 2001), 41.

${ }^{337}$ Fontaine, "Language, Society, and Development," 37.

${ }^{338}$ Carolyn Fick, The Making of Haiti: The Saint Domingue Revolution From Below (Knoxville : University of Tennessee Press, 1990), 40.
} 
unifying tool that enabled...[them] to share experiences, exchange views and opinions, communicate their ideas, and even conspire against the master." ${ }^{, 339}$ Once again, in the 1970s and 80s, Creole would become the language of rebellion against elite rule. This is why some have argued that prior to the Jean-Claude regime's all-out assault against all forms of political opposition in 1980, the primary targets of the regime were Creolespeaking journalists. Creole was viewed as the language of subversion. ${ }^{340}$

The switch to Creole as the language of public discourse brought the peasant and urban poor into the public sphere in a way they had not been allowed throughout Haiti's history, placing its most disenfranchised at the forefront of the mass rebellion against Duvalierisme. Peasants, once too far removed from the centers of power to know the details of palace politics in the "Republic of Port-au-Prince," were suddenly tuned in to the latest political developments as cheap transistor radios penetrated Haiti's countryside. Increasingly, those isolated by geography, bad roads, illiteracy, and systemic repression, were being heard directly by millions across the country. "The use of Creole in the news...[meant] empowerment for the majority who, for the first time, could express themselves directly via microphone to a listening audience, discuss their own problems, and suggest their own solutions. ${ }^{341}$ The radio provided them with information, increased their orientation towards politics, and impressed upon them the need for democratic change. ${ }^{342}$

\footnotetext{
${ }^{339}$ Ibid.

${ }^{340}$ Fontaine, "Language, Society, and Development," 41.

${ }^{341}$ Montas-Dominique, "The Role of the Press," 399.

${ }^{342}$ Gerard Pierre-Charles and Margaret Low, "The Democratic Revolution in Haiti," Latin American Perspectives 15, no. 3 (1988): 66.
} 
The media's embrace of Creole as the language of public discourse was part of a broad cultural shift. The growing power of the movement for democracy in Haiti during the 1980 s could be seen in the increasing legitimation of Creole as the language of the country and its people. In 1987, it was legally established in the new post-Duvalier Constitution as an official language of Haiti. ${ }^{343}$ Laws were implemented requiring Haitian schools to teach school children primarily in Creole before shifting to French later on in their schooling. ${ }^{344}$ The promotion of literacy in Creole was viewed by many within the popular movement as fundamental to broader political participation and Haitian democracy. ${ }^{345}$

\section{LIBERATING THE HAITIAN CHURCH}

While Haitian radio provided the grassroots movement for democracy with a medium for public discourse, the Church became a central institution in its ideological and organizational development. This was the result of significant changes occurring in the Catholic Church both within Haiti and throughout Latin America and the Caribbean in general.

Like much of the Latin American Church, the Catholic Church in Haiti has historically sided with the most powerful institutions in Haitian society, often tacitly accepting the subjugation and exploitation of Haiti's poor and destitute masses. But, as

\footnotetext{
${ }^{343}$ Neyfakh, "The Power of Creole," Boston.com.

${ }^{344}$ Ibid.

${ }^{345}$ Marlise Simons, "Church in Haiti Launches Literacy Drive," New York Times, March 11, 1986.
} 
new ideologies appeared throughout the region in the middle of the $20^{\text {th }}$ Century, the Church's role in Latin American society was fundamentally challenged. While the noiriste ${ }^{346}$ Francois Duvalier was weakening the power of the Church in Haiti, throughout the rest of Latin America, the rise of liberal, nationalist, leftist, and Marxist ideologies threatened the very existence of the Church. This period was characterized by the upending of traditional elite symbols and institutions by peasant and indigenous movements for cultural representation; the transformation of elite-controlled parties of notables into mass parties; the rise to power of popular organizations; as well as signature reforms in education, literacy, labor rights, trade unionism, land rights, and social security. $^{347}$

As Latin America was increasingly threatened by social revolution, the Church sought to reform itself to align more closely with the region's poor through the Second Vatican Council (Vatican II) between 1962 and $1965 .{ }^{348}$ These reforms increased the usage of local languages in parts of the mass; encouraged congregational participation, thus affirming the capacity of the laity for some leadership role within the Church; and promoted efforts to reduce poverty and other forms of inequality. ${ }^{349}$ Nonetheless, certain segments of the Church sought to move past reform. Instead, radical Christian doctrines focused on empowering the poor and disenfranchised developed throughout Latin

\footnotetext{
${ }^{346}$ A black nationalist movement that emerged following the 1915 - 1934 U.S. occupation of Haiti.

${ }^{347}$ Alan Knight, "Democratic and Revolutionary Traditions in Latin America," Bulletin of Latin American Research 20, no. 2 (April 2001): 167.

${ }^{348}$ Greene, The Catholic Church in Haiti, 7.

${ }^{349}$ Ibid.
} 
America in response to the crisis of development plaguing the region at the time. ${ }^{350}$ None were more central to the transformation of the Latin American Church than Liberation Theology.

Rather than interpreting the Bible as calling for passivity in the face of worldly inequality and misery, liberation theology called on the Church to join the struggle against oppression in the here and now. Its adherents exhorted the Church to embrace a position that emphasized the well-being of the poor and powerless of society as expressed in Biblical teachings, what they called the "preferential option for the poor." 351 They pointed to the life of Jesus, who championed the cause of the poor and downtrodden while confronting the abuses of corrupt politicians and religious figures, as a principle example of this preferential option. ${ }^{352}$ At the 1968 Conference of Latin American Bishops (CELAM) in Medellín, this perspective was affirmed, and the Christian understanding of 'salvation' in the after-life was wedded to the struggle for 'liberation' in the present. This would be the ideological base from which the grassroots movement for democracy in Haiti would grow.

The emergence of liberation theology in Haiti followed important changes in the composition of the Haitian clergy made by Francois Duvalier. After expelling much of the foreign Church hierarchy, thought to be antagonistic to his noiriste and pro-Vodou orientations, and subsequent excommunication, Duvalier was able to reach a

\footnotetext{
${ }^{350}$ Michael Dodson, "Liberation Theology and Christian Radicalism in Contemporary Latin America, Journal of Latin American Studies 11, no. 1 (May 1979), 204.

${ }^{351}$ Michael Griffin and Jennie Weiss Block (ed.), In the Company of the Poor: Conversations with Paul Farmer and Fr. Gustavo Gutiérrez (Maryknoll, New York: Orbis Books, 2013).

${ }^{352}$ Greene, The Catholic Church in Haiti, 9.
} 
rapprochement with the Church in 1966, whereby he was allowed to name the country's bishops with the approval of the Holy See. While nearly two-thirds of Haiti's Catholic clergy were foreigners when Duvalier took power in 1957, by 1985 the exact opposite was true. "The Church would no longer be a white, largely French, institution with foreign loyalties. The presence of Haitian bishops would encourage the growth of an indigenous clergy," fundamentally better able to understand the country and its people. ${ }^{353}$ Little was it understood by the dictatorship how true this statement would become, and more importantly, how threatening this would be for the continuation of Duvalierisme.

Most of the young Haitian priests appointed during the Duvalier period were from poor and middle class rural families, and thus very much aware of the conditions faced by Haiti's impoverished peasantry. Aristide himself was born into a poor peasant family in Port-Salut, later moving to Port-au-Prince as a result of his father's death, where in 1958 he began his schooling with the Salesian priests, and in 1982, in the midst of the growing movement against Duvalierisme, was ordained as a Salesian priest. ${ }^{354}$

Like Aristide, many priests realized that a central reason for popular ambivalence towards the Church in Haiti was due to its failures to address the fundamental issues facing the country's poor. So, after receiving training abroad, many returned home to Haiti's rural communities and urban slums to engage in grassroots development work, ${ }^{355}$ increasingly pushing the Church to recognize "the needs, aspirations and possibilities of [the] People of God, in Haiti as elsewhere," as its primary concern, rejecting what was

\footnotetext{
${ }^{353}$ Greene, The Catholic Church in Haiti, 113-114.

${ }^{354}$ Marika Lynch, "Aristide: A Hope Reshaped," Miami Herald, February 29, 2004.

${ }^{355}$ Greene, p. 126-127
} 
increasingly viewed as the false separation between the spiritual and the temporal. ${ }^{356}$ The Haitian Church thus shifted from being an institution focused nearly exclusively with the spiritual and educational progress of the Francophile urban elite, to one focused on the collective welfare of the nation's poor masses. ${ }^{357}$

These priests became active in establishing a variety of organizations and institutions that began as measures to address the dearth of pastoral services in Haiti's rural areas but transformed into vehicles to face the various economic, social, and later, political issues plaguing the country's poor. Chief amongst these were the Christian Base Communities. Like elsewhere in Latin America, these places where small groups of peasants met to discuss local problems and organize social action through the Church, became critical sources of popular power. These Christian Base Communities, known in Haiti as the Ti-Légliz (Little Churches), l'eglise qui vit la vie du people (the Church that lives the life of the people), and Ti Kominote (Little Communities), were strongly influenced by liberation theology, and were thus "the most wide-ranging and perhaps the most important examples of the new Church and synthesis of religious and secular work." 358

For Bob Corbett, who sat in hundreds of Ti Légliz meetings throughout the country for over a decade or so, these were a manifestation of the Church's shift from the individual's relationship with God, towards a focus on the relationships between those

\footnotetext{
${ }^{356}$ Anne Greene, The Catholic Church in Haiti, 116.

${ }^{357}$ Ibid., 132.

${ }^{358}$ Ibid., 133. Also known as Ecclesiastical Base Communities, Basic Christian Communities, Ecclesial Base Communities, or Communautés Ecclésiastiques de Base (CEBs).
} 
within the community. It was a shift away from hierarchy and towards an egalitarian ethos. "Gone [was] the hierarchy (which is the main reason they were lay-led and not clergy led). Gone [was] the authority (which is why the leader tend[ed] overwhelmingly to ask questions and not give answers).",359 Also, "only one language [was] ever mentioned or used" in these meetings: Creole. ${ }^{360}$ These were fundamental affirmations of the centrality of the voices of the Haitian poor in the Ti Legliz movement, and later, the Lavalas movement.

Christian Base Communities, believed to have first appeared in the Brazilian countryside during the $1950 \mathrm{~s}$, were critical to the praxis of liberation theology. ${ }^{361}$ They played a key role in raising the consciousness and confidence of poor and working class people. "They offer[ed] their members a sense of community, the opportunity to discuss problems, and the collective strength to resolve some of them." 362 As institutions somewhat removed from the all-seeing-eye of the Church hierarchy, they served as democratizing forces within the religion, helping to establish a foundation for the emergence of civil society and political organizing that would occur during the period of liberalization.

Alongside the Ti Legliz, various other Catholic organizations were established to engage in development work. These included rural producers' cooperatives and Christian Development Centers (CCDs); organizations such as the Institut d'Education des Adultes

\footnotetext{
${ }^{359}$ Bob Corbett, "Democracy and the Ti Legliz Movement," Bob Corbett's Haiti Page, Webster University, June 1999, http://www2.webster.edu/ corbetre/haiti/misctopic/ti-legliz/democracy.htm.

${ }^{360}$ Corbett, "Democracy and the Ti Legliz," June 1999.

${ }^{361}$ Greene, The Catholic Church in Haiti, 8.

${ }^{362}$ Ibid.
} 
(IDEA) and CARITAS which focused on stimulating rural development by improving the human capital of Haiti's peasantry, training them for positions as community leaders, and establishing a grassroots infrastructure in the countryside ${ }^{363}$; religious orders, like Aristide's Salesians ${ }^{364}$ and the Twelve Catholic Sisters Charity, which worked with and cared for the sick and the poor in the urban slums of Port-au-Prince, like Cité Simone (now Cité Soleil); and various other entities such as women's groups, literacy centers, dispensaries, clinics, banks, technical assistance groups, agricultural associations, and neighborhood committees. Nearly sixty or so lay groups were engaged in development work in Port-au-Prince alone, while three to four hundred more worked throughout Haiti’s countryside. $^{365}$

While the Ti Legliz did not begin with an overtly political agenda, its ability to shift the consciousness of Haiti's poor had profound political implications. The poor were no longer passive in the face of the various problems that overwhelmed their communities; they were being transformed into active agents. Increasingly, a feeling and sense of self-consciousness and solidarity began developing in the hearts and minds of Haiti's poor through their participation in the Ti Legliz. ${ }^{366}$ This was "grass roots local democracy being born. No talk of 'Haiti' or 'the nation' ... it was stuff like: how can we grow more food for us (as opposed to the land owner) so we do not suffer hunger? How can we get schools for our children and ourselves, so that we aren't so uninformed of

\footnotetext{
${ }^{363}$ Ibid. 166-167.

${ }^{364}$ Ibid. 141.

${ }^{365}$ Ibid. 168-169.

${ }^{366}$ Ibid.
} 
what's going on...How can we get safer water to drink that isn't so distant from our village and home? ${ }^{\text {"367 }}$ They initially focused primarily on addressing basic local needs. Nevertheless, in a context where the freedom to assemble for overtly political purposes was denied to the population by the Duvalier dictatorship, the Ti Legliz and other religious organizations provided the organizational framework for the mass movement towards democracy. ${ }^{368}$

As the Catholic Church strengthened its position in Haiti's rural communities and urban slums, teaching the country's poor to solve their problems through their own collective action, it proved increasingly threatening to the Duvalier dictatorship, which relied on collective apathy and disillusionment to remain in power. As it increasingly reached poor communities across the country through its radio programming, pastoral letters, and Christian Base Communities, the Church created one of the few national networks that could rival that of tonton macoutes, chef de section, ${ }^{369}$ spies, and the like, built by the Duvaliers over their decades in power. ${ }^{370}$ More importantly, the Church's grassroots institutions were doing the work that the government should have been doing, thus providing the people with a vision of what an alternative Haiti, one that was more democratic and socially just, could look like; one that placed them at its center.

\footnotetext{
${ }^{367}$ Corbett, "Democracy and the Ti Legliz," June 1999.

${ }^{368}$ Dennis Volman, "'Revolutionary Process' Has Begun in Haiti, Says Prominent Former Exile," Christian Science Monitor, February 21, 1986.

${ }^{369}$ Military officers appointed from amongst the peasantry as the state's representative in rural areas. Jean

L. Comhaire, "The Haitian 'Chef de Section,'" American Anthropologist 57, no. 3, part 1 (June 1955): 621.

${ }^{370}$ Greene, The Catholic Church in Haiti, 133.
} 
Eventually, the Ti Legliz's work to empower poor people at the local level to better their conditions shifted towards challenging local authorities and elites who relied on marginalization and servitude to maintain power. Efforts to dismantle local power structures inexorably led to an understanding that they were part and parcel of a larger network of control and domination being sustained by the Duvalier regime in Port-auPrince. Increasingly it was understood that the poverty of the Haitian masses could not be adequately dealt with without addressing the "social-political conditions of the nation at large, ${ }^{, 371}$ which meant that the activist segments of the Church would have to challenge the repressive government and the class structure that sustained it. ${ }^{372}$

They increasingly criticized the government's expropriation of the country's most valuable lands and natural resources, excessively regressive tax structures that transferred wealth from the poor to the elite and those in power, ${ }^{373}$ and general government corruption. The Church eventually turned into a vehicle for poor Haitians to challenge the Duvalieriste dictatorships and Haitian elites who supported preserving substantial aspects of the status quo once Duvalier was removed from power.

As Jean-Claude's so-called liberalization came to an end with the election of Ronald Reagan to the U.S. presidency, and repression came back on the table as a suitable tool to prevent radical socioeconomic and political change in Haiti, ${ }^{374}$ the Church and its various institutions remained the sole bulwark against the state. While initially

\footnotetext{
${ }^{371}$ Ibid., 143.

${ }^{372}$ Nicholls, "Haiti: The Rise and Fall of Duvalierism," 1246.

${ }^{373}$ Greene, The Catholic Church in Haiti, 177.

${ }^{374}$ Nicholls, "Haiti: The Rise and Fall of Duvalierism," 1242.
} 
focusing exclusively on denouncing the regime's attacks against Church activists, it increasingly challenged all government repression. It also highlighted the government's failures to meet stated development and political promises. "The Church was becoming the authority Haitians trusted; working throughout Haiti, protecting people from abuse, and keeping them informed. ${ }^{375}$

Escalating regime repression was matched by an increasingly revolutionary tone within the activist Church. They eventually called for the destruction of the current structure of society and the building of a new one, ${ }^{376}$ with the Ti Legliz in the vanguard of this revolutionary project. ${ }^{377}$ With the fall of the Duvalier dynasty in 1986, the Catholic Church was poised to become the institution to lead the country towards a democratic future. Haitians' sense of the Church's role in the ousting of Jean-Claude and in building a democratic future was portrayed in a variety of ways. Many flew the yellow-and-white colors of the Catholic Church alongside the nation's new red-and-blue flag. ${ }^{378}$ Others painted anonymous murals depicting the Church as a benevolent force for change, Christ the Liberator breaking the chains of the people, the sun in veneration of the Church's Radio Soleil [soleil means sun in Haitian Creole], as well as images of the Pope with the words 'on our side. ${ }^{379}$ The Church had provided the primary ideological and organizational foundations for the mass movement for democracy in Haiti.

\footnotetext{
${ }^{375}$ Greene, The Catholic Church in Haiti, 129.

${ }^{376}$ Ibid., 200.

${ }^{377}$ Ibid., 131.

${ }^{378}$ Gail Pellet, "Ti Legliz: Liberation Theology in Haiti," New Age Magazine, July/August 1986, http://gailpellettproductions.com/ti-legliz-liberation-theology-in-haiti/.

${ }^{379}$ Nicholls, "Haiti: The Rise and Fall of Duvalierism," 1246.
} 


\section{REDEFINING HUMAN RIGHTS, CONSTRAINING DEMOCRACY}

While the growing importance of democracy promotion within U.S. foreign policy was instrumental in the 1986 ouster of dictator Jean-Claude Duvalier and the eventual free and fair election of Jean-Bertrand Aristide in 1991, its primary objective as formulated by the Ronald Reagan administration was to constrain the boundaries of change that were being fought for by the various progressive and radical movements throughout the Third World, including the popular movement for democracy in Haiti that came to be known as Lavalas.

As Ronald Reagan came to power in 1980, the previous restraints on the Duvalier regime's capacity to use force against the popular movement for democracy in Haiti placed on it by the Carter administration's human rights agenda were subsequently lifted. Jean-Claude was essentially allowed to reassert the dictatorial essence of Duvalierisme. The regime systematically targeted the progressive media and critical elements of the Catholic Church, particularly the Ti Legliz. In 1983 the Haitian constitution was revised to reduce the power of the legislature, and as President-for-Life, Duvalier was given the ability to adjourn or dissolve the chamber at will, to appoint judges and appeal their decisions, as well as the right to name his successor. In the following year, all non-jeanclaudiste political groups were banned, corresponding with a systematic rise in the arbitrary arrest and persecution of members of the independent media critical of the dictatorship. Nevertheless, this return to a more overt autocracy was paralleled by further pretensions towards liberalization. In 1985, the regime held a national referendum on a number of constitutional reforms implemented the year prior. Political parties were granted the right to participate in national politics granted they met a number of criteria 
outlined by the regime, one of those being the recognition of Jean-Claude as presidentfor-life and his right to name his heir. According to the regime, an absurd $99.8 \%$ of voters were in favor of the proposals, which supposedly gave legitimacy to the Duvalier dynasty. ${ }^{380}$ Content with these 'progressive' steps forward, the Reagan government assured the American Congress of Haiti's emerging democratization and improved human rights, thus sanctioning the continued flow of military and economic aid to the country. ${ }^{381}$

Fundamental to Reagan's support for Jean-Claude as autocrat was a critique of Jimmy Carter's human rights policy. "Throughout the 1980 presidential campaign, candidate Reagan clearly and sharply criticized the Carter human rights policy, arguing that it was morally unsound, ineffective, and threatening to United States' security interests." 382 "Reagan promised that he would initiate a more realistic human rights program, ${ }^{383}$ one that would allow it to address the precipitous collapse of authoritarian regimes in Central America, like that of West Point graduate Anastasio Samoza Debayle whose family had held power in Nicaragua since 1936 through the U.S created National Guard, at the hands of the Sandinista National Liberation Front (FSLN) in the late 1970s. The Salvadoran civil war that broke out between the right-wing junta, also supported by the U.S., and the leftist Farabundo Martí National Liberation Front (FMLN), that

\footnotetext{
${ }^{380}$ Ferguson, Papa Doc, Baby Doc, 83-84.

${ }^{381}$ Farmer, The Uses of Haiti, 22.

${ }^{382}$ Carleton and Stohl, "The Foreign Policy of Human Rights," 205.

${ }^{383}$ Ibid.
} 
paralleled the Sandinistas coming to power, further highlighted the need to reassess U.S. foreign policy. ${ }^{384}$

A seminal figure in this reassessment was Georgetown University professor Dr. Jeane J. Kirkpatrick. In 1979 Kirkpatrick published an article that challenged the Carter administration's notion that there was a democratic alternative to deteriorating authoritarian governments. She believed that it was likely that the collapse of these regimes would lead to some form of Marxist revolutionary government if the United States did not act to defend its allies ${ }^{385}$ Kirkpatrick eventually served as Reagan's foreign policy adviser during his 1980 campaign, and was later appointed ambassador to the United Nations, the first woman and first Latin Americanist to occupy that position. ${ }^{386}$ While the Carter administration made substantial efforts to reign in the violent actions of authoritarian regimes against their populations by tying economic and military aid to specific improvements on human rights, Reagan whole-heartedly rejected this position once his administration came to power. Kirkpatrick attacked Carter for opposing authoritarian governments merely because they violated human rights, challenging the idea that change in such autocracies was inevitable, desirable, or even in the American interest. She viewed Carter's application of his "utopian" conception of human rights as undermining the capacity of regimes friendly to U.S. interests in the region to stay in

\footnotetext{
${ }^{384}$ Enrique A. Baloyra, "Central America on the Reagan Watch: Rhetoric and Reality," Journal of Interamerican Studies and World Affairs 27, no. 1 (February 1985): 36-37.

${ }^{385}$ Ibid., 36-37.

${ }^{386}$ Baloyra, "Central America on the Reagan Watch," 38.
} 
power while strengthening opposition movements that were anti-American from their inception, thus making neither likely to be susceptible to U.S. influence. ${ }^{387}$

Kirkpatrick, along with the Reagan administration's appointee to the United Nations Commission on Human Rights, Michael Novak, legitimated support for authoritarian regimes by distinguishing them from totalitarian ones. They considered this the most important political distinction of the twentieth century. Kirkpatrick and Novak argued that while "authoritarians sought to preserve 'traditional' societies," they also "maintained open capitalist economies." On the other hand, "totalitarians... sought to control every part of society, including the economy. ${ }^{, 388}$ Thus, not all nations erred against human rights more or less equally. ${ }^{389}$ Though the right-wing authoritarians that the U.S. had maintained as allies repressed popular movements, they typically left in place traditional allocations of wealth, power, status, and other resources. Leftist Communist regimes, it was argued, were fundamentally different. They disturbed the "habitual rhythms of work and leisure, habitual places of residence, habitual patterns of family and personal relations...creat[ing] refugees by the million because they claim the jurisdiction over the whole life of the society. ${ }^{.390}$ Moreover, while change was possible under authoritarian regimes, such change could not be expected under totalitarianism. So, a realistic human rights policy would support the former as the lesser of two evils, and as a means to pre-empt the latter. This formulation was applied to the Haiti case.

\footnotetext{
${ }^{387}$ Carleton and Stohl, "The Foreign Policy of Human Rights," 209.

${ }^{388}$ Walter Lafeber, Inevitable Revolutions: The United States in Central America, (New York: Norton, 1983), 6 .

${ }^{389}$ Carleton and Stohl, "The Foreign Policy of Human Rights," 209.

${ }^{390}$ Ibid., 209-210.
} 
Once Reagan came to power in 1981, U.S. foreign policy focused less on the Duvalier regime's human rights record, and more on economic reforms and modernization as significant criteria for aid. This was in line with the Reagan administrations understanding of human rights, particularly the distinctions between authoritarian and totalitarian regimes. The belief was that societies like Haiti were naturally authoritarian, but that through economic restructuring and free-market economic reform, the subsequent economic growth would produce the conditions necessary for the emergence of a society that respects human rights, and eventually democracy. Authoritarian regimes like Jean-Claude's could be expected to eventually democratize because they were willing to allow freedoms in certain aspects of society, namely the economy, while radical communist regimes allowed no freedoms at all. By promoting free-market economic reforms in Haiti, the Reagan administration believed that it was also promoting the changes necessary to move Haiti closer to protecting human rights in the long term.

So efforts to restructure the Haitian economy began in earnest with the 1982 appointment of former World Bank official Marc Bazin who initiated major reforms involving the national bank, corruption, and the issue of rampant smuggling. Bazin's threat to the economic structure of Duvalier cronyism led to his prompt removal. But there were other means to push the regime to open the Haitian economy to greater U.S. influence. In exchange for \$37.2 million in August 1982 from the IMF, Duvalier acquiesced to a number of structural reforms involving Haiti's system of taxation and removal of barriers to increased foreign investment. Almost immediately US offshore assembly plants increased their level of activity within the country, prompting President 
Reagan to send a letter to Duvalier praising Jean-Claude for his commitment to private enterprise and economic reform. ${ }^{391}$

Thus in the 1980s, the Jean-Claudistes and their international patrons embarked on a development strategy focused on shifting the country's remaining agricultural production away from local consumption towards export. This new development strategy advocated the establishment of agro-industrial plants in the countryside to process export crops, while encouraging the growth of Port-au-Prince's assembly industry as an alternative source of employment for the displaced rural population. The foreign exchange earnings from this new export-oriented development paradigm would then be used to import food no longer produced domestically. This began the process of subsidized foreign rice flooding Haiti's market, destroying Haitian rice farming, and subsequently inducing the mass migration of peasants to the capital for jobs in the assembly sector. ${ }^{392}$ For continued U.S. support in the form of economic aid that the regime could pilfer, Baby Doc provided a welcoming investment climate of minimal taxes, a general ban on trade unions, low-wages, and unrestricted repatriation of profits. Haiti became open for business. The export-manufacturing zones that emerged in Portau-Prince during François Duvalier's rule expanded dramatically in the 1970s and 80s under Jean-Claude's tutelage from 13 in 1966 to nearly 240 by the early 1980s, making Haiti the ninth largest assembler of goods for U.S. consumption in the world. ${ }^{393}$ By 1986

\footnotetext{
${ }^{391}$ Ibid., 73-74.

392 Josh Dewind, \& David H. Kinley, Aiding Migration: The Impact of International Development Assistance on Haiti (Boulder: Westview Press, 1988): 59.

${ }^{393}$ Yasmine Shamsie, "Time For a 'High-Road Approach to EPZ Development in Haiti," Paper presented at Conflict Prevention and Peace Forum (CPPF), Social Science Research Council, 5-7, Retrieved from http://www.ssrc.org/publications/view/03C92980-9E49-E011-9A1B-001CC477EC84/.
} 
the number swelled to over 300 U.S. firms. ${ }^{394}$ In terms of agriculture, the value of US exports to Haiti nearly tripled during this same period. While business was good for U.S. companies, wages for the average Haitian between 1980 and 1990 declined by about $50 \%$, falling in line with the broader doldrums of the region during what came to be known as the 'Lost Decade., 395

During this same period, the population of Port-au-Prince grew at an unsustainable rate as people left the countryside in hopes of finding jobs in the lightmanufacturing industry, ${ }^{396}$ from nearly 460,000 in the 1960 s to over one million in the 1980s. The next three largest cities in the country also experienced similar growth rates during these decades, with Cap Haïtien going from 45,600 to 89,200, Gonaïves from 28,700 to 58,300, and Les Cayes from 22,600 to 62,500 people. ${ }^{397}$ This period was particularly marked by an increase in the proportion of the population under the age of $30{ }^{398}$ As the rhetoric of a more promising future espoused by Jean-Claudisme was fundamentally contradicted by the regime's corruption, extortion, and economic mismanagement, as well as its turn to repression, this growing urban youth population stood up defiantly against the dictatorship. "It was the inhabitants of the provincial cities,

\footnotetext{
${ }^{394}$ Peter Hallward, Damming the Flood: Haiti, Aristide, and the Politics of Containment (London; New York: Verso, 2007), 15.

${ }^{395}$ Hallward, Damming the Flood, 15.

${ }^{396}$ Shamsie, Time for a 'high-road approach, 5-7.

${ }^{397}$ Alejandro Portes, José Itzigsohn, and Carlos Dore-Cabral, "Urbanization in the Caribbean Basin: Social Change During the Years of the Crisis, Latin American Research Review 29, no. 2 (1994): 15.

${ }^{398}$ Beatrice Daumerie and Karen Hardee, "The Effects of a Very Young Age Structure on Haiti: Country Case Study," Population Action International, The Shape of Things to Come Series, 5, http://populationaction.org/wp-content/uploads/2011/12/SOTC_Haiti.pdf.
} 
especially the young people and students, who held the demonstrations and marches that convinced the President he had lost support." 399

As U.S.-backed Contras and the right-wing governments that remained in power in neighboring countries engaged in the wholesale slaughter of their civilian populations, pressures on the Reagan administration both domestically and amongst its Latin American and European allies to discontinue its support for all repressive regimes across the region increased. ${ }^{400}$ This was true for the Duvalier regime as well, forcing the Reagan administration to slowly move away from providing it with support.

Also, it was increasingly understood that the repression of these regimes was simply radicalizing the popular movements rather than eliminating them. Some within the administration began to acknowledge that it was because of the repressiveness and corruptness of these various autocrats that such broad support for change had emerged. While these societies had fundamentally changed, undergoing dramatic socioeconomic transformations in terms of population growth and the expansion of their urban middle and working classes, there had been no transformation politically. ${ }^{401}$ In Central America, movements for change began as rather moderate broad-based alliances between the Catholic Church, the professional classes, as well as working class and peasant-based movements. ${ }^{402}$ The same could be said about the mobilization for democracy in Haiti.

\footnotetext{
${ }^{399}$ Greene, The Catholic Church in Haiti, 194.

${ }^{400}$ Walter Lafeber, "The Reagan Administration and Revolutions in Central America," Political Science Quarterly 99, no. 1 (Spring, 1984), 13-17.

${ }^{401}$ Robert Pastor, "Continuity and Change in U.S. Foreign Policy: Carter and Reagan on El Salvador," Journal of Policy Analysis and Management 3, no. 2 (Winter 1984): 176-177.

${ }^{402}$ Lafeber, "The Reagan Administration and Revolutions," p 3.
} 
Some within the administration realized that "authoritarians had exploited and divided their societies until radical revolution became the last hope of the masses and the middle class. ${ }^{403}$ As the movement in Haiti escalated, the Reagan administration sought to forestall this possibility by facilitating a transition from the Duvaliers to the $\mathrm{CNG}$, and promising democratic elections.

The crisis of legitimacy that plagued the various U.S.-supported right-wing regimes throughout the Third World during this period pushed the Reagan regime to reassess its foreign policy strategy. It would come to moderate its public support for Kirkpatrick's call to arm the authoritarians, though continuing to do so in more subtle ways, and to increasingly promote a shift towards the democracy promotion as a key component of U.S. foreign policy. ${ }^{404}$ Principal to this undertaking were those like Secretary of State George P. Shultz. First he challenged the notion that democracy was not possible in the developing world by pointing to democratic developments in southern Europe and South America. ${ }^{405} \mathrm{He}$ also acknowledged that inequality throughout the region was a significant barrier to democracy in Central America and the Caribbean, but that radicals were taking advantage of this reality to push for new undemocratic revolutionary orders. ${ }^{406}$ This interpretation of developments within the region would allow the Reagan administration to at once denounce the leftists as anti-democrats, but

\footnotetext{
${ }^{403}$ Ibid.

${ }^{404}$ Fred Halliday, The Making of the Second Cold War (London: Verso, 1983).

${ }^{405}$ Enrique A. Baloyra, "Central America on the Reagan Watch: Rhetoric and Reality," Journal of Interamerican Studies and World Affairs 27, no. 1 (February 1985): 39.

${ }^{406}$ Ibid., 42.
} 
also to proclaim its support for important democratic and economic reforms throughout the region, thus narrowing the distance between U.S. material interests and its supposed concern for particular values. ${ }^{407}$

More importantly, the human rights agenda would be subsumed within the framework of democracy promotion. Rather than being understood as an international standard, the Reagan administration reduced human rights to represent "a set of values embedded in existing national political institutions and legal structures, of which the United States were at once the best historical example and the model. In substance, a concern for human rights should be a concern about the political regime predicated on human rights, namely democracy." ${ }^{408}$

But what kind of democracy would this new foreign policy promote? The Reagan administration strategically reduced the fight for political rights as one that excluded social and economic rights, and focused instead on political processes and institutions. ${ }^{409}$ While the previous international conception of human rights "actually made progress in the field of political and civil rights dependent upon the improvement of social and economic conditions, ${ }^{410}$ the Reagan administration's notion of human rights involved preserving the status quo distribution of economic power in many of the Third World countries it sought to democratize.

\footnotetext{
${ }^{407}$ Fareed Zakaria, "The Reagan Strategy of Containment," Political Science Quarterly 105, no. 3 (Autumn 1990): 377.

${ }^{408}$ Nicolas Guilhot, The Democracy Makers: Human Rights and the Politics of Global Order (New York: Columbia University Press, 2012): 75-76.

${ }^{409}$ Ibid., 20-21.

${ }^{410}$ Ibid., 76-77.
} 
Under Shultz's direction, the State Department would come to organize the Campaign for Democracy, Project Democracy, and the National Endowment for Democracy, all to give leverage to independent political groups in democratizing nations. ${ }^{411}$ These developments allowed the Reagan administration to gradually expand the foreign policy discourse beyond material interests of physical security, well being, and access to markets, goods, and investments, towards a seemingly broader conception of interests, which included the promotion of democracy and capitalism. ${ }^{412}$ Unfortunately, it was strategically ensured that democracy being advocated was a shell of what democracy traditionally meant, particularly for the left. Democracy was now a conservative tool for managing transitions from overtly authoritarian regimes.

The United States' shift from explanations of its foreign policy in Central America and the Caribbean that focused on security to those that emphasized protecting democracy and human rights was a means to maintain public support and legitimacy of its foreign policy domestically and among its allies in Latin America and Europe. Later this policy would become more strategic, more pre-emptive, as a means to deal with the broader issue of the authoritarian crises facing regimes around the world that were friendly to the U.S. It could also be used to remove leftist regimes that the U.S. viewed as reprehensible. It placed U.S. foreign policy in the developing world on a better moral footing, and removed the notion that its efforts in these countries were purely based on interests. "Following the U.S. diplomatic interventions against Jean-Claude Duvalier in Haiti...the administration released a presidential message in March 1986 that seemingly

\footnotetext{
${ }^{411}$ Zakaria, "The Reagan Strategy of Containment," 377.

${ }^{412}$ Ibid., 375.
} 
broadened U.S. goals to include support for all opposition to tyranny, whether of the right or the left." ${ }^{\text {413 }}$ Its shift towards supporting democratization and human rights policy became a means for it to export "a variety of political technologies, legal models, normative discourses regarding the economy or the organization of civil society." ${ }^{414}$ Democracy-promotion thus ceased to be a cloak under which to hide or justify more violent tactics, but became a non-violent means to penetrate societies and forestall grassroots movements from taking power. Suddenly democracy became relegated to the realm of experts, many who invariably emanate from the fount of democracy, the United States, rather than within the grassroots movement that mobilized for democratic change.

\section{THE EMBERS OF A NEW HAITI}

Unfortunately for U.S. democracy promoters, the mass mobilization for democracy in Haiti did not end with the ouster of Jean-Claude Duvalier. While the media and the Church served as the primary avenues through which the Haitian majority would come to acquire a new social and political consciousness, they also taught them to reject the received wisdom that society's institutions existed to serve the elite. Increasingly they came to espouse the belief that Haitian institutions should serve the poor who made up the country's majority, and sought to either transform these institutions, or abandoned them outright to create their own when doing so proved impossible.

The first aspect of this emergent sense of agency amongst the poor who made up the bulk of the popular movement was the rejection of the notion that democracy could

\footnotetext{
${ }^{413}$ Johnson 510.

${ }^{414}$ Guilhot, The Democracy Makers, 18.
} 
be established in Haiti by simply removing Duvalier from power and having elections. For the movement, the Duvaliers were simply the public faces of a power structure that infiltrated every facet of Haitian society. The movement sought to go beyond the elections championed by the international community, towards an overhaul of Haitian society itself. They called for Dechoukaj.

As a word borrowed from Haitian peasant life, "to dechouke a plant is to pull it up by its roots. It was a particularly apt metaphor for political changes after Duvalier, because it recognized that the dictatorship was more than an oppressive overlay kept in power by force alone, but that it had sunk its roots deeply into Haitian society and culture." ${ }^{, 45}$ Thus dechoukaj encompassed the entirety of the popular effort to remove Duvalierists and Duvalierisme from all areas of economic, social, and political power, and to empower the people in all these spheres. The word therefore was used both to refer to the killing of makouts and the ransacking of the homes, businesses, or offices of Duvalierists, as well as the closing down or reforming of institutions, the firing of Duvalierist managers, the changing of Duvalier-era laws, and even the changing of popular beliefs and understandings. ${ }^{416}$

The movement also challenged the CNGs elections as disingenuous, and as "a diversion from the work of building the popular movement. ${ }^{417}$ Instead, it called on the CNG to 'rache manyòk, bannou tè blanch' (pull up your manioc fields, give us a clean field), "a reference to land tenancy practices whereby a new landowner or tenant would

\footnotetext{
${ }^{415}$ Averill, A Day for the Hunter, 161.

${ }^{416}$ Ibid., 161.

${ }^{417}$ Ibid., 173.
} 
take possession only after the former occupant uprooted their maniocs," a call for the CNG and the army to remove themselves from power in order for true democracy to begin. $^{418}$

This true democracy lay beyond the formal arena of politics as understood by advocates of a polyarchic understanding of democracy. Democracy could not be reduced to elections and elite bargaining within institutions. True democracy was what was developing within the Ti Legliz. The Ti Legliz did not initially focus on politics per se. It first began by democratizing the Church and the relationship between priests and its members, emphasizing the capacity of poor Haitians to speak for themselves; to understand their own problems; to organize within the Church to seek solutions; and to confront structures of power when it became evident that they were the main causes of these problems. The Ti Legliz provided a blue print for establishing democracy in Haiti. For the movement, all institutions throughout Haitian society would have to be transformed in much the same way the Ti Legliz sought to transform the Catholic Church, in order for democracy to flourish.

As the Ti Legliz sought to lead the charge in democratizing Haitian society after the fall of Duvalier, the Church hierarchy sought to extricate itself nearly completely from the political arena. It urged Haitians to practice restraint, to avoid violence, to respect property, and to forgive. ${ }^{419}$ It called upon Haitian Bishops and priests to withdraw from political debates, ${ }^{420}$ and took aggressive actions against those who did not follow

\footnotetext{
${ }^{418}$ Ibid.

${ }^{419}$ Greene, The Catholic Church in Haiti, 211.

${ }^{420}$ Ibid., 228.
} 
these directives. While critical voices within Radio Soleil were muted, ${ }^{421}$ and progressive seminarians dismissed, ${ }^{422}$ the Church simultaneously rewarded and promoted conservatives who were known to either have strong links to the Duvaliers or to have conservative views. ${ }^{423}$ Even during the CNG's systematic campaign of violence against Church institutions that remained critical of its actions, the Church hierarchy called for the people to avoid violence and to resolve political issues non-violently, ${ }^{424}$ making it clear to the public that the Church hierarchy did not wish to see fundamental changes in the distribution of power throughout Haitian society.

This shift in the Church towards the preservation of elite power in Haiti pushed many within the popular movement to begin organizing autonomously outside of the Church. Some transformed their existing structures into more secularly-oriented popular organizations. ${ }^{425}$ Organizations such as Mouvement Paysans de Papaye/Peasant Movement of Papaye (MPP), founded in the early 1970s to train people for religious work, ${ }^{426}$ became overtly political, establishing the National Peasant Movement of the Papaye Congress (MPNKP) in 1987, which boasted nearly 100,000 members before the 1991 coup against the Aristide government. ${ }^{427}$ MPP served as a model for other peasant

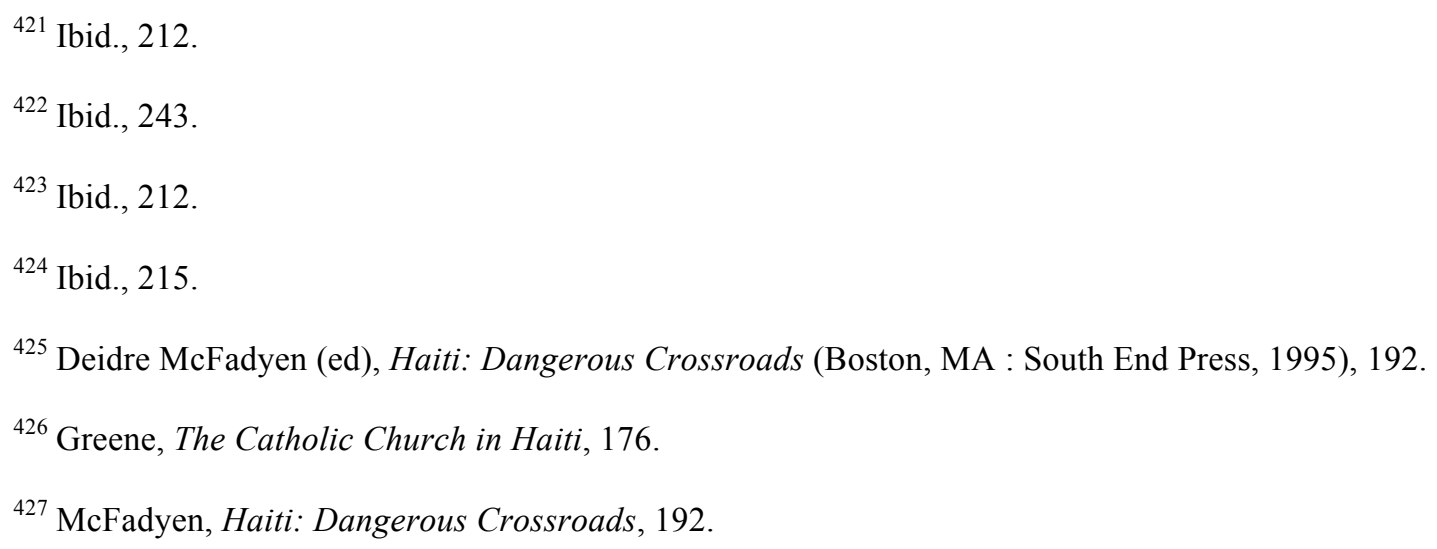


collectives like the Tèt Kole Ti Peyizan (Heads Together Little Peasants) movement started in $1986 .{ }^{428}$

Others "formed non-denominational gwoupman, community groups where issues such as agrarian reform, taxation, or irrigation were addressed." ${ }^{, 429}$ They used marches and land occupations to fight for agrarian reform and to take back lands previously stolen from them by tontons macoutes. They called for the elimination of the chef de section system. They sought to change the regressive tax system that distributed their hard earned income upward to the wealthy elite by refusing to pay taxes at all. They championed the repopulation of Haiti's black pigs that were eradicated in the early 1980 s by the now infamous USAID program. In addition, they fought to establish Creole as an official language of public discourse and government. ${ }^{430}$

Most critical to the next phase of the mass movement for democracy was the emergence of Organisations Populaires/Popular Organizations (OPs/POs). ${ }^{431}$ Many of these Popular Organizations formed in places like Cité Soleil (Sun City), ${ }^{432}$ still a Lavalas stronghold today. Previously named Cité Simone after the elder Duvalier's wife, Cité Soleil encapsulates many of the trends that fueled the popular movement against the

\footnotetext{
${ }^{428}$ Ibid., 192.

429 "Anthropology and Theology in Pursuit of Justice (Vodou, the Catholic Church, Arsitide, Ti Legliz)," 820 .

${ }^{430}$ McFadyen, Haiti: Dangerous Crossroads, 192.

${ }^{431}$ Luc Smarth, "Popular Organizations and the Transition to Democracy in Haiti" in Community Power and Grassroots Democracy - The transformation of Social Life (Ottawa: International Development Research Centre, 1997).

${ }^{432}$ Was renamed after the fall of Duvalier to Cité Soley after the Catholic Church's Radyo Soley. Helen Scott, "Haiti Under the Eagle," SocialistWorker.org (blog), January 26, 2010, http://socialistworker.org/2010/01/26/haiti-under-the-eagle.
} 
Duvalier dictatorship. Though currently a slum situated on the northern edge of Port-auPrince, the community began as a planned housing development for 52 families that worked in the former HASCO sugar complex in 1958, but later came to house those who migrated from the countryside in search of work in the nearby Export Processing Zone. ${ }^{433}$ Even today "Cité Soleil...[remains] a highly migratory community with strong ties to rural areas....Most of the residents...were born outside Port-au-Prince and had migrated to the city in search of better economic prospects. They came from rural-based farming and marketing families who faced decreased prospects for production. ${ }^{434}$ Cité Soleil is one example of how the rural-urban migration and slum development caused by the neoliberal economic paradigm fueled social mobilization. Others included Bel Air, La Saline, and Martissant. "By the mid-80s, a new generation was coming of age in the sprawling slums of Port-au-Prince, open to the appeal of liberation theology in the coded kreyòl sermons of radical priests — chief among them, Jean-Bertrand Aristide." ${ }^{435}$ From their inception, the young people who formed these Popular Organizations rejected the mere institutional trappings of democracy being promoted by those they deemed part of Haiti's professional political class. They saw formal political parties as no more than patronage networks around which the spoils of state power could be

\footnotetext{
${ }^{433}$ United States, Agency for International Development, "Urban Health and Community DevelopmentPhase II," Project Paper (May 1984), retrieved from http://pdf.usaid.gov/pdf_docs/PDAAT248.pdf; Fred Rosensweig, Chris McGahey, Richard Noth, Lonna Shafritz, and Peter Gottert, "A Plan for CDS to Establish a Water and Sanitation District in Cité Soleil, Haiti and Monitoring Visit Report," Activity Report No. 21, United States Agency for International Development (May 1996), retrieved from http://pdf.usaid.gov/pdf_docs/PNABY701.pdf.

${ }^{434}$ Catherine M. Maternowska, Reproducing Inequalities: Poverty and the Politics of Population in Haiti (New Brunswick, N.J.: Rutgers University Press, 2006), 5-6.

${ }^{435}$ Peter Hallward, "Option Zero in Haiti," New Left Review 27 (May-June 2004), http://newleftreview.org/II/27/peter-hallward-option-zero-in-haiti.
} 
distributed. Instead they defined their objective as spreading and defending the rights and claims of the popular classes through the 'power of the street.' "As far as POs were concerned, the people could only count on their own autonomous forms of organization...They were radically opposed to traditional, elitist practices that excluded or suppressed the will of the majority."

In fact, two Popular Organizations that emerged during the 1985-86 period in Aristide's Saint Jean Bosco parish, Solidarité Ant Jèn (SAJ, Solidarity Among the Youths) and Konbit Véyé Yo (Vigilance Committee), joined other organizations like the Tèt Kolé pou Youn Mouvman ti-Peyizan (Solidarity with the Small Peasant Movement) in publicly opposing Aristide's decision to participate in the 1990 elections. ${ }^{437}$ Instead, many Popular Organizations believed that democracy had to begin with ordinary Haitians organizing in their neighborhoods to take action where the state had not. This meant cleaning streets, planting trees, and painting murals to improve otherwise pitiable public spaces, ${ }^{438}$ and arranging basic social services that the state was unwilling or unable to provide for the poor people of Haiti's slums. ${ }^{439}$ This also meant organizing to protect themselves from the reactionary violence of the military dictatorship and their macoute allies, and at times, to exact revenge for past injustices.

\footnotetext{
${ }^{436}$ Smarth, Popular Organizations and the Transition, 1997.

${ }^{437}$ Dupuy, The Prophet and the Power, 87-88.

${ }^{438}$ Smarth, Popular Organizations and the Transition, 1997.

${ }^{439}$ Deborah Lynn Dimmett, "Haiti's Urban Poor Responds to Socio-Political and Socio-Cultural Conflicts: A Case Study of the Grande Ravine Community Human Rights Council," Ph.D. Dissertation, University of Arizona, 2010, Proquest Dissertations Publishing (3408334), 118.
} 
Despite a certain ambivalence to formal electoral politics, it was the Ti Legliz, various peasant organizations, and the Popular Organizations that flourished in the period immediately after the fall of the Duvalier dictatorship that would prove critical in the election of Jean-Bertrand Aristide, establishing themselves as the most functional structures in the nation's democratic movement. ${ }^{440}$ Aristide's election was a fundamental rejection that democracy would become the purview of the middle and upper classes; something left up to the professionals.

${ }^{440}$ Smarth, Popular Organizations and the Transition, 1997. 


\section{CHAPTER IV.}

\section{CRAFTING A DEMOCRACY THAT BINDS \\ INTRODUCTION}

Between Jean-Claude Duvalier's ouster in 1986 and Jean-Bertrand Aristide's election in 1990, Haiti's ostensible democratic transition vacillated between violently aborted elections, dubiously selected civilian governments, and more-or-less repressive military juntas, devolving into what came to be known infamously as a period of "Duvalierism without Duvalier." ${ }^{441}$ But why had democracy stalled in Haiti over these 4 years, when a number of powerful domestic and international stakeholders were proclaiming their unequivocal support for a transition to democracy from Duvalier's Presidency-for-Life? The question was not whether these power brokers supported democracy in Haiti, but rather what kind of democracy were they seeking to establish? The truth is, as Haiti's poor, peasant, and working class masses mobilized to dismantle the dark legacy of the Duvalier regime, U.S. foreign policy makers, the High Command of the Haitian Armed Forces, and a number of prominent Haitian politicians were working to craft a polyarchic vision of democracy, utilizing the rhetoric and processes of "democratization" to prevent a radical rupture with Haiti's authoritarian past. As efforts to push forward a people's agenda gained momentum, a return to repression was utilized to reset the so-called democratization process, with the hope of moving towards elections without the input of the poor and working class masses.

\footnotetext{
${ }^{441}$ Serge Beaulieu, "7 Killed As Police Break Up Demonstration," Madrid EFE [English Translation], April 26, 1986, Foreign Broadcast Information Service (FBIS) Daily Reports, Latin America, April 28, 1986.
} 
While, at a minimum, polyarchy depends on freedom of expression, associational autonomy, and free and fair elections, ${ }^{42}$ what made polyarchy a particularly useful interpretation of democracy for power brokers within and outside of Haiti was its rejection of popular participation in the political process, outside of voting, as a necessary condition for democracy. One of the principal theorists of polyarchy, Robert Dahl, argued that, "what we call 'democracy' — that is, a system of decision-making in which leaders are more or less responsive to the preferences of nonleaders - does seem to operate with a relatively low level of citizen participation." ${ }^{443}$ This sentiment was echoed within the democratic transition literature. While popular mobilization was deemed necessary for the dismantling of dictatorships, it could not continue indefinitely if democracy was to be consolidated. Accordingly, democracy required a certain degree of "normalcy," which entailed the "de-politicization and de-radicalization" of the population. ${ }^{444}$ The population was to become "disillusioned and fatigued" with the political process, making them ripe to be "co-opted by better organized and financially more independent social forces," particularly the "formerly excluded parties and leaders of the dominant classes and middle sectors." $" 445$

Alongside the emergence of a narrowly defined opposition, polyarchy relies on convincing moderates within the previous authoritarian regime, as well as the social classes that supported them, to tolerate new "conflicts and demands, modifications in the

${ }^{442}$ Dahl, Democracy and Its Critics, 221.

${ }^{443}$ Krouse, "Polyarchy and Democracy," 443 - 444.

${ }^{444}$ Guillermo O’Donnell, Philippe C. Schmitter, Transitions from Authoritarian Rule: Tentative Conclusions about Uncertain Democracies" (Baltimore: Johns Hopkins University Press, 1986), 26.

${ }^{445}$ Fatton, Haiti's Predatory Republic, 17. 
rules of the game and institutional arrangements, as well as levels and patterns of popular demands and organization they would never have accepted at the beginning of the transition..."446 In a polyarchic vision of democracy, the accountability of government to the people is not established by mass participation in government, but by the bargaining and negotiating of organized groups of minorities within representative institutions. ${ }^{447}$ Dahl admits that, "attached to the institutions of polyarchal democracy...is a nondemocratic process...[of] bargaining among political and bureaucratic elites."

Through its emphasis on the processes of decision-making rather than the substance of these processes, polyarchy serves as a useful tool for demobilizing the poor and working class majority. While a classical conceptualization of democracy views popular participation in politics as necessarily resulting in a more equitable distribution of power and resources within society, polyarchy views this as outside the purview of the democratic process. Polyarchy thus involves the establishment of nominally democratic institutions and processes that filter and fragment the common agenda of the masses so as not to threaten the interests of power brokers.

This chapter focuses on the immediate aftermath of Jean-Claude Duvalier's removal from power in 1986, and the efforts of different powerbrokers to neutralize popular criticism of the National Government Council's legitimacy as the institution to move Haiti's democratic transition forward. It addresses the popular ratification of the Constitution of 1987, specifically Article 291 barring Duvalierists from holding public

\footnotetext{
${ }^{446}$ O’Donnell and Schmitter, Transitions from Authoritarian Rule, 27-28.

${ }^{447}$ Krouse, "Polyarchy and Democracy," 443 - 444.

${ }^{448}$ Dahl, On Democracy, 113-114.
} 
office for 10 years, and how this became emblematic of the popular movement's ability to co-opt processes initially designed to establish polyarchy for their own agenda. This period concludes with the violently aborted elections of November 29, 1987.

\section{SECURING THE STATE}

Within the context of a widening legitimacy crisis for U.S.-supported authoritarian regimes across Latin America and the Caribbean in the 1980s, the proximate concern of U.S. foreign policy makers regarding Haiti was stability and continuity. The day of Jean-Claude's departure, "Defense Secretary Caspar Weinberger said...the U.S. was very anxious to have stable conditions in Haiti." ${ }^{449}$ This meant demobilizing the popular protest movement, weakening the dominant position of the Tonton Macoutes and other hard-line Duvalierists, and subsequently strengthening that of a reformed and professionalized Forces Armées d'Haïti (Fad'H) that would then secure the authority of a transition government. This, it was hoped, would ensure that the contagion of leftist popular uprisings springing forth from Central America would not infect Haiti, and potentially the rest of the Caribbean. The U.S. would facilitate "the peaceful departure [of Jean-Claude]...in order to ease the transition in Haiti and reduce the possible bloodshed." ${ }^{450}$ Nevertheless, as the U.S., the CNG, and the so-called moderate opposition sought to navigate their way towards the electoral politics that are the sine qua non of polyarchy, the popular movement would consistently question the

\footnotetext{
449 "Consultations Under Way With New Haitian Government," Beijing Xinhua [English Translation], February 8, 1986, Foreign Broadcast Information Service (FBIS) Daily Reports, China, February 12, 1986. ${ }^{450}$ Ibid.
} 
very legitimacy of the $\mathrm{CNG}$, eventually commandeering the process of democratic transition to push forward an anti-Duvalierist, anti-imperialist, and pro-poor agenda.

Nearly immediately after Jean-Claude's departure, the U.S. declared Haiti's Armed Forces the country's best hope for democracy, ${ }^{451}$ certifying that his heirs in the CNG were complying with the human rights conditions needed to resume aid. ${ }^{452}$ This would lead to the releasing of $\$ 26$ million in withheld assistance, and the petitioning of Congress for $\$ 52$ million more. ${ }^{453}$ In 1971, U.S. Ambassador to Haiti Clinton Knox had similarly exclaimed, "that with U.S. aid Papa Doc's successor would free the country,",454 as Jean-Claude Duvalier inherited the office of President of Haiti at the age of 19.

To enhance the CNG's democratic pedigree, it was floated early on that longstanding opponent of the Duvaliers and President of the Haitian League for Human Rights, Gerard Gourgue, would be the probable head of the provisional government. ${ }^{455}$ Though his eventual appointment as Minister of Justice was praised, ${ }^{456}$ it would become increasingly clear that his function was to provide a patina of popular legitimacy to what was essentially a military dictatorship. Four of the six members of the CNG were military

${ }^{451}$ Ibid.

${ }^{452}$ National Coalition for Haitian Refugees, "The Political and Human Rights Crisis in Haiti: Terror and the Elections of 1987," Haitian Dechoukaj Collection, Box 1, Folder 8, 8.

453 "Consultations Under Way With New Haitian Government," Beijing Xinhua [English Translation], February 8, 1986, Foreign Broadcast Information Service (FBIS) Daily Reports, China, February 12, 1986.

454 "Haitian Regime 'Characterized by U.S. Domination,'" Havana International Service [English Translation], August 6, 1985, Foreign Broadcast Information Service (FBIS) Daily Reports, Latin America, August 9, 1985.

455 "Duvalier Leaves; Possible Successors Mentioned," Paris AFP [English Translation], February 7, 1986, Foreign Broadcast Information Service (FBIS) Daily Reports, Latin America, February 7, 1986.

456 "Violence, Looting Reported; Cabinet Appointed," Madrid EFE [English Translation], February 8, 1986, Foreign Broadcast Information Service (FBIS) Daily Reports, Latin America, February 10, 1986. 
officers. The eventual President, Lieutenant General Henri Namphy, was Commander-inChief of the Army. Colonel William Regala was his assistant. And Colonels Prosper Avril and Max Valles were heads of the presidential police. ${ }^{457}$

While symbolically distancing itself from the legacy of the Duvaliers by officially disbanding the Tontons Macoutes ${ }^{458}$ dismissing the Haitian Parliament created in the fraudulent elections of 1984, ${ }^{459}$ and abandoning François Duvalier's black and red flag for the blue and red flag of independence, the reality was that the CNG, and the Haitian Armed Forces that gave it authority, were dominated by Duvalierists. In fact, the one other civilian member in the CNG besides Gourgue, Alex Cineas, "held a string of important posts under the Duvaliers" and was viewed as a Tonton Macoute by many in the popular movement. ${ }^{460}$ Worse yet, as the CNG called for an investigation into the size of Duvalier's wealth and how it was acquired, ${ }^{461}$ one of its very own members, Prosper Avril, had been Jean-Claude's "closest financial confidant during that time and kept accounts of all the dictator's financial transactions." ${ }^{462}$ Avril was a member of François' Presidential Guard, and later became a close adviser to Jean-Claude. Similarly, a majority

\footnotetext{
457 "Duvalier Leaves," Paris AFP, February 7, 1986.

458 "New Government to Disband 'Tontons Macoutes,"' Hong Kong AFP [English Translation], February 10, 1986, Foreign Broadcast Information Service (FBIS) Daily Reports, Latin America, February 10, 1986.

459 "Council Announces Dissolution of Parliament," Paris AFP [English Translation], February 10, 1986, Foreign Broadcast Information Service (FBIS) Daily Reports, Latin America, February 10, 1986.

460 "Justice Minister Protests Pierre's Departure," Bridgetown CANA [English Translation], February 25, 1986, Foreign Broadcast Information Service (FBIS) Daily Reports, Latin America, February 26, 1986.

461 "Education Minister Calls for Duvalier Probe," Bridgetown CANA [English Translation], February 18, 1986, Foreign Broadcast Information Service (FBIS) Daily Reports, Latin America, February 20, 1986.

${ }^{462}$ Don Terry, "Artful Career Officer: Prosper Avril," New York Times, September 19, 1988.
} 
of the provisional government's cabinet members were also well-known Duvalier supporters. $^{463}$

On February 11, 1986, an unsigned 25-demand document that came to be known as the Gonaives Manifesto circulated throughout Port-au-Prince in the name of the Haitian people. ${ }^{464}$ The first element of the people's agenda was Dechoukaj. While Dechoukaj was often narrowly associated with the mob lynching of members of Duvalier's reviled Tonton Macoutes, the term itself referred to the pulling of a plant up by its roots so that it would not grow again. According to Rene Theodore of the Parti Unifié des Communistes Haïtiens (PUCH), "after overthrowing the Duvalier government, the Haitian popular movement [was] pursuing a very clear objective--cleansing the country of all remnants of Duvalierism..." ${ }^{465}$ For the mass movement, this first meant removing Duvalierist elements from the $\mathrm{CNG}$, if not pushing for the dissolution of the $\mathrm{CNG}$ altogether. Youth demonstrations throughout the capital and the provinces denounced Duvalierist members of the $\mathrm{CNG}^{466}$ calling for the removal of Alex Cineas and Prosper Avril in particular. ${ }^{467}$ As the $\mathrm{CNG}$ attempted to reopen schools shuttered since the

\footnotetext{
463 "Violence, Looting Reported; Cabinet Appointed," Madrid EFE [English Translation], February 8, 1986, Foreign Broadcast Information Service (FBIS) Daily Reports, Latin America, February 10, 1986.

464 "Commentary Criticizes U.S. Role in Haiti's Affairs," Havana International Service [English Translation], February 15, 1986, Foreign Broadcast Information Service (FBIS) Daily Reports, Latin America, February 20, 1986.

465 "Haiti's Rene Theodore on 'U.S. Maneuvering,"' Havana International Service [English Translation], February 16, 1986, Foreign Broadcast Information Service (FBIS) Daily Reports, Latin America, February 20, 1986.

466 "Demonstrators Demand Elections," Madrid EFE [English Translation], February 13, 1986, Foreign Broadcast Information Service (FBIS) Daily Reports, Latin America, February 13, 1986.

467 "Leader Urged to Dismiss Duvalier Supporters," Hong Kong AFP [English Translation], February 20, 1986, Foreign Broadcast Information Service (FBIS) Daily Reports, Latin America, February 20, 1986.
} 
popular mobilization against Jean-Claude, students across the provinces boycotted, "calling for the removal of the six-member military civilian government council almost from the start, saying most of its members and numerous Cabinet officials and ministers [were] tainted by past links to Duvalier." ${ }^{468}$ In some instances, public demonstrations barred newly appointed ministers from entering their offices due to their past affiliations with the Duvalier regime. ${ }^{469}$

The popular movement also called for justice, and thus the extradition, arrest, and trial of anyone who had committed human rights violations against the population or diverted public funds during the 28 -year rule of the Duvalier family. ${ }^{470}$ Emphasis was particularly placed on the extradition of Jean-Claude Duvalier and other Gros Macoutes who were able to flee the country. ${ }^{471}$ Yet, as Justice Minister Gerard Gourgue came out on national television to declare that the CNG would request the extradition of Duvalier from France, ${ }^{472}$ the Haitian military was playing a covert role in facilitating the departure of many of the most reviled Macoutes out of the country. Under the cover of the CNG's nighttime curfew, the Haitian Army assisted notorious former Police Chief Albert Pierre, along with other prominent macoutes, escape into exile for Brazil. ${ }^{473}$ "In three years as

\footnotetext{
468 "Schools Reopen; Students Call for Elections," Bridgetown CANA [English Translation], February 17, 1986, Foreign Broadcast Information Service (FBIS) Daily Reports, Latin America, February 18, 1986.

469 "Demonstrators Protest Two Minister Appointments," Madrid EFE [English Translation], February 11, 1986, Foreign Broadcast Information Service (FBIS) Daily Reports, Latin America, February 11, 1986.

470 "Looting Resumes, List of Demands Circulates," Bridgetown CANA [English Translation], February 11, 1986, Foreign Broadcast Information Service (FBIS) Daily Reports, Latin America, February 12, 1986.

${ }^{471}$ Ibid.

472 "Government to Press for Duvalier's Extradition," Bridgetown CANA [English Translation], February 28, 1986, Foreign Broadcast Information Service (FBIS) Daily Reports, Latin America, March 3, 1986.

473 "Police Chief Given Asylum at Brazilian Embassy," Paris AFP [English Translation], February 23,
} 
chief of police and security services, Pierre won a reputation for exceptional brutality. According to some accounts, he frequently tortured prisoners and delighted in wearing a white hospital coat during torture sessions because he enjoyed seeing the stains left by his victims blood." ${ }^{474}$ It was not until an angry mob physically prevented the Haitian Army from escorting infamous former Haitian Secret Police Chief, Luc Desyr, to his Air France flight out of the country, did the CNG publicly denounce this policy, arrest Desyr, and declare that he would be put on trail. ${ }^{475}$ U.S. aid would subsequently be doubled to $\$ 108$ million, with $\$ 1.275$ million in Military Assistance Program Funds, $\$ 275,000$ in International Military Education and Training Funds, ${ }^{476}$ along with $\$ 400,000$ worth in riot control equipment. ${ }^{477}$ And with this military aid, the CNG was to help the Haitian people find their way to democracy.

According to Namphy, what the Haitian people wanted was "a liberal constitution, the reconstruction of a legislative branch resulting from free elections, and presidential elections by direct universal suffrage..." ${ }^{478}$ So on February 26, 1986, the CNG announced plans to form a Constituent Assembly to draft a new Constitution along

\footnotetext{
1986, Foreign Broadcast Information Service (FBIS) Daily Reports, Latin America, February 24, 1986.

474 "Justice Minister Protests Pierre's Departure," Bridgetown CANA [English Translation], February 25, 1986, Foreign Broadcast Information Service (FBIS) Daily Reports, Latin America, February 26, 1986.

475 "Army Forces Sent to Quell Disturbances," Paris AFP [English Translation], February 25, 1986, Foreign Broadcast Information Service (FBIS) Daily Reports, Latin America, February 26, 1986.

${ }^{476}$ National Coalition for Haitian Refugees, "The Political and Human Rights Crisis in Haiti: Terror and the Elections of 1987," Haitian Dechoukaj Collection, Box 1, Folder 8, 8.

${ }^{477}$ Americas Watch, National Coalition for Haitian Refugees, "Haiti 1987 Election Watch: A Democracy Through Terror," Haitian Dechoukaj Collection, Box 1, Folder 8, 1-2.

478 "Namphy Promises Direct Presidential Elections," Madrid EFE [English Translation], February 10, 1986, Foreign Broadcast Information Service (FBIS) Daily Reports, Latin America, February 11, 1986.
} 
with electoral laws. ${ }^{479} 480$ These developments would be watched with much reserve considering how the U.S. had applauded feigned steps towards political liberalization before in the not so distant past. Only a few months prior to the eruption of the mass protests that forced Jean-Claude out of power, U.S. diplomats were calling his fraudulent "political structure" referendum "a positive step for Haiti," claiming that "the human rights situation in the country...had improved..." ${ }^{481}$ As the referendum affirmed 30 constitutional amendments put forward by his handpicked unicameral legislature, JeanClaude was given power over the newly created prime minister position; power to fire elected town mayors; ${ }^{482}$ and power to revoke the newly established right of political parties to exist should they fail to recognize "the Republic's president as supreme arbiter and guarantor of the stability of the national institutions for life." ${ }^{483}$ Duvalier would win the July 1985 referendum in the island's nine districts ${ }^{484}$ with nearly 2.4 of the reported 2.6 million total votes. ${ }^{485}$ Despite denunciations of the entire process by the Haitian

\footnotetext{
${ }^{479}$ National Coalition for Haitian Refugees, "Haiti 1987 Election Watch: A Democracy Through Terror," Haitian Dechoukaj Collection, Box 1, Folder 8, 2.

480 "Government to Press for Duvalier's Extradition," Bridgetown CANA [English Translation], February 28, 1986, Foreign Broadcast Information Service (FBIS) Daily Reports, Latin America, March 3, 1986.

481 "Government Predicts Duvalier Referendum Triumph," Bridgetown CANA [English Translation], July 23, 1985, Foreign Broadcast Information Service (FBIS) Daily Reports, Latin America, July 24, 1985.

482 "Legislature Amends National Constitution," Bonaire Trans World Radio [English Translation], June 7, 1985, Foreign Broadcast Information Service (FBIS) Daily Reports, Latin America, June 11, 1985.

483 "Adopts Political Parties Bill," Paris AFP [English Translation], June 9, 1985, Foreign Broadcast Information Service (FBIS) Daily Reports, Latin America, June 11, 1985.

484 "Duvalier Government Reportedly Wins Referendum," Madrid EFE [English Translation], July 24, 1985, Foreign Broadcast Information Service (FBIS) Daily Reports, Latin America, July 25, 1985.

485 "Duvalier Wins 'Political Structure' Referendum," Hamburg DPA [English Translation], July 26, 1985, Foreign Broadcast Information Service (FBIS) Daily Reports, Latin America, July 30, 1985.
} 
Catholic radio station Radio Soleil, ${ }^{486}$ Reagan's State Department and White House would continue to declare their support for the regime, approving \$53 million in aid. ${ }^{487}$ Following the referendum, Minister of State Jean-Marie Chanoine would declare on national television that the opposition had two choices: "to leave or support the Haitian Government." 488

On March 20, 1986, troops from the Leopard battalion, created with U.S. assistance in 1971, would go on to kill unarmed protestors in the towns of Martissant and Carrefour, ${ }^{489}$ prompting the resignation of Gourgue, the one member of the CNG with a modicum of public trust. ${ }^{490}$ This marked a significant demarcation in the initial transition period, symbolizing the CNG's failure at the outset to mask its authoritarian roots and to quietly contain the mass movement in order to manage the transition. Gourgue's departure led to the removal of the most visible Duvalierists from the $\mathrm{CNG}$, such as Colonels Prosper Avril and Max Valles, as well as civilian Alex Cineas. ${ }^{491}$ Namphy

\footnotetext{
486 "Duvalier Government Reportedly Wins Referendum," Madrid EFE, July 24, 1985.

487 "Haitian Delegate Speaks At Parties' Conference," Managua Domestic Service [English Translation], February 11, 1986, Foreign Broadcast Information Service (FBIS) Daily Reports, Latin America, February $13,1986$.

488 "Duvalier Wins," Hamburg DPA, July 26, 1985.

${ }^{489}$ National Coalition for Haitian Refugees, Americas Watch, "Haiti 1987 Election Watch: A Democracy Through Terror," Box 1, Folder 8, Haitian Dechoukaj Collection, 2.

490 "Gourgue Explains Reasons for Resignation," Paris AFP [English Translation], March 21, 1986, Foreign Broadcast Information Service (FBIS) Daily Reports, Latin America March 24, 1986.

491 "Armed Forces Reorganize Government Council," Paris AFP [English Translation], March 21, 1986, Foreign Broadcast Information Service (FBIS) Daily Reports, Latin America, March 24, 1986.
} 
would declare that "this reshuffle was done to strengthen democracy; that is, for democracy to bloom in Haiti." 492

Nonetheless, in the aftermath of the military's repression, 15,000 people would march through Port-au-Prince, led by a newly-formed group called the Komite pour Ignite Demokrasi/the Committee to Ignite Democracy (KID), made up of journalists, students, and young priests of the Ti Legliz. One of its principal leaders, Evans Paul, and former Creole Radio newsman, Kompere Plume, called "on Haitians to organize themselves along democratic lines in neighborhoods, schools, and work..." ${ }^{493}$ KID would be one of the organizations to promote an alternative to CNG-managed elections. Parallel to the march, young unemployed youths set tires and trash on fire at intersections throughout the poor sections of Port-au-Prince, stating that "as long as the army's man (Namphy) is in power we will never have any real free elections. We need civilians to pave the way for democracy." ${ }^{494}$ Despite the CNG's promises of democracy, the popular movement continued to mobilize in the streets, leading Namphy to increasingly use reactionary rhetoric and threaten systematic violence against the population. A month later, on April 26, 1986, as approximately 7,000 people marched to the infamous Forte Dimanche Prison, where prisoners during Jean-Claude Duvalier's regime often entered without returning, to memorialize the victims of François Duvalier's reign of terror, the

\footnotetext{
492 "Interview with Theodore," Havana International Service [English Translation], March 23, 1986, Foreign Broadcast Information Service (FBIS) Daily Reports, Latin America, March 31, 1986.

493 "Demonstrators Call for Civilian Government," Bridgetown CANA [English Translation], March 24, 1986, Foreign Broadcast Information Service (FBIS) Daily Reports, Latin America, March 25, 1986.

494 "Street Fires Set to Protest Military Government," Bridgetown CANA [English Translation], March 25, 1986, Foreign Broadcast Information Service (FBIS) Daily Reports, Latin America, March 26, 1986.
} 
marchers were shot on by the police. ${ }^{495}$ After this act of repression, Namphy "accused 'a small group of agitators' of provoking the troops," claiming that they were attempting to find an opportunity to destabilize the government in order to "interrupt the process of democratization and 'establish a totalitarian regime." ${ }^{496}$ The attack would be the worst by the CNG since the ouster of Jean-Claude. ${ }^{497}$ As the fear of further popular unrest grew, Elliot Abrams, Assistant Secretary of State for Inter-American Affairs, and Brigadier General Frederick Gordon, Director of the U.S. Defense Department Inter-American region, visited Haitian officials to find a means to stave off further instability. ${ }^{498}$

Protests would reemerge in June as the population focused its attention on the policies of the Minister of Finance and Economy, Leslie Delatour. As plans to close the state-owned sugar and oil plants and sell a cement and a flour plant to the private sector $^{499}$ were discovered in a leaked confidential report from the U.S. Embassy in Haiti, ${ }^{500}$ Delatour was denounced as "an American minister who sold out to the World Bank." ${ }^{501}$ Regardless, Justice Minister Francois Latortue would declare that it was not

495 "7 Killed As Police Break Up Demonstration," Madrid EFE [English Translation], April 26, 1986, Foreign Broadcast Information Service (FBIS) Daily Reports, Latin America, April 28, 1986.

496 "Namphy Blames 'Agitators,"' Buenos Aires Reuter [English Translation], April 28, 1986, Foreign Broadcast Information Service (FBIS) Daily Reports, Latin America, April 28, 1986.

497 "Opposition Calls for Strike, Council Resignation," Bonaire Trans World Radio [English Translation], April 28, 1986, Foreign Broadcast Information Service (FBIS) Daily Reports, Latin America, May 1, 1986.

498 "Reports Indicate No Real Changes in Haiti," Havana International Service [English Translation], May 13, 1986, Foreign Broadcast Information Service (FBIS) Daily Reports, Latin America, May 15, 1986.

499 "Politicians Call for 3-Day General Strike," Buenos Aires Reuter [English Translation], June 7, 1986, Foreign Broadcast Information Service (FBIS) Daily Reports, Latin America, June 9, 1986.

500 "Electoral Timetable Announced," Paris AFP [English Translation], June 8, 1986, Foreign Broadcast Information Service (FBIS) Daily Reports, Latin America, June 9, 1986.

501 "Namphy Warns of Civil War," Bridgetown CANA [English Translation], June 5, 1986, Foreign Broadcast Information Service (FBIS) Daily Reports, Latin America, June 6, 1986. 
possible to replace Delatour because he had begun many projects that must be completed, and that they did not want to "create an image of a country that changes governments every week." ${ }^{502}$ Nevertheless, in the midst of this popular unrest, the CNG would announce that it would turn over power to a freely elected government on February 7 , 1988, exactly two years from the day of Jean-Claude's departure. ${ }^{503}$ The next steps were to: "1) to regulate the political parties by decree; 2) to form a constituent assembly; 3) to draft a liberal, democratic constitution." ${ }^{504}$

As the CNG moved the country towards elections, supporters of the ousted JeanClaude Duvalier regime began coming forward to declare their intention to present a candidate for the upcoming 1987 presidential elections. ${ }^{505}$ "A source close to the government said: 'This party is the only one among more than 200 that has a possibility of winning.' The same source added: 'They know how to organize themselves and fight in an electoral campaign. Do not forget that 'Papa Doc' was democratically elected in 1957."'506 Simultaneously, rumors concerning the return of the Tonton Macoutes would also grow louder. ${ }^{507}$ While Namphy had formally disbanded the Tonton Macoutes, those

\footnotetext{
502 "Politicians Call for 3-Day General Strike," Buenos Aires Reuter [English Translation], June 7, 1986, Foreign Broadcast Information Service (FBIS) Daily Reports, Latin America, June 9, 1986.

503 "Gen Namphy Announces Elections for 1987," Hamburg DPA [English Translation], June 8, 1986, Foreign Broadcast Information Service (FBIS) Daily Reports, Latin America, June 9, 1986.

504 Ibid.

505 "Thionier Revives Duvalierist REN Party," Buenos Aires Reuter [English Translation], October 31, 1986, Foreign Broadcast Information Service (FBIS) Daily Reports, Latin America, October 31, 1986. 506 Ibid.

507 "Commentary on Return of Haitian Tonton Macoutes," Havana International Service [English Translation], October 31, 1986, Foreign Broadcast Information Service (FBIS) Daily Reports, Latin America, November 4, 1986.
} 
who escaped the wrath of dechoukaj, were able to retain their weapons. So, as the specter of open Duvalierism reappeared in Haiti, an estimated 50 thousand people took to the streets in protest ${ }^{508}$ in "one of the most important demonstrations following the downfall of 'Duvalierism' last 7 February." 509

Rather than acknowledge the legitimacy of the popular mobilization against the possibility of a growing Duvalierist and Macoute threat, Namphy argued that the CNG was caught between the radical right and radical left. While the CNG was fighting to eliminate the "arbitrary and repressive practices of the past" associated with Macoutism, it faced an unnamed sector that was infiltrating peaceful demonstrations to "pit the people against the Army and the government," to "at any cost and means...ruin the budding Haitian democracy." ${ }^{510}$ Claims that the military has engaged in repression against the population were simply dismissed as policing accidents that were exploited by activists. Namphy called on "reporters, political leaders, and priests to cease the 'exaggerations and the countertruths that stir passions," 511 "of a people who have lived for 30 years under a regressive dictatorship and never had the chance to express themselves." ${ }^{512}$ These were

\footnotetext{
508 "Barrack Besieged; 1 Killed," Bonaire Trans World Radio [English Translation], November 8, 1986, Foreign Broadcast Information Service (FBIS) Daily Reports, Latin America, November 10, 1986.

509 "President Namphy Vows to 'Eliminate' Macoutism," Paris AFP [English Translation], November 13, 1986, Foreign Broadcast Information Service (FBIS) Daily Reports, Latin America, November 13, 1986.

${ }^{510}$ Ibid.

511 Ibid.

512 "Namphy Discusses Transition to Democracy," Namphy Discusses Transition to Democracy [English Translation], February 7, 1987, Foreign Broadcast Information Service (FBIS) Daily Reports, Latin America, February 12, 1987.
} 
conditions for "an explosion" as there was "now a desire to take an interest in public affairs." $^{513}$

While the CNG was working to establish democracy in Haiti, Namphy also believed that the population was "not yet sufficiently well- informed to decide which option meets their wishes." ${ }^{514}$ As a result, "the government that would be chosen might not be the one that the Haitian people wanted right away." ${ }^{515}$ This is a sentiment that would be echoed by other figures within the CNG. According to Education Minister Rosny Desroches, "there was an unrealistic gap between public expectations from the transitional administration and what it was able to deliver...It had to prepare for a permanent government and a return to democracy, yet was faced with demands from the Haitian people for significant economic advance..." ${ }^{516}$ Essentially, the participation of the people in politics could not be connected to their economic advance. The two were mutually exclusive. For Desroches, the two-year transitional period established by the CNG was reasonable, so that the appropriate political structures could be established, along with the appropriate economic orientation for the country. "Although there was no specific tendency within the group forming the council, Desroches said that it, influenced by the private sector, was for the evolution of a Haiti with a capitalist economy and close ties to the United States.... "517

\footnotetext{
${ }^{513}$ Ibid.

${ }^{514}$ Ibid.

${ }^{515}$ Ibid.

516 "Army 'Unlikely' to Retain Power Past 1988," Bridgetown CANA [English Translation], December 4, 1986, Foreign Broadcast Information Service (FBIS) Daily Reports, Latin America, December 5, 1986. ${ }^{517}$ Ibid.
} 
What these statements reveal is that the transition away from Jean-Claude Duvalier's presidency-for-life was never about allowing Haiti's working class and peasant majority participate in the political process, nor to meet their demands. Rather, the twoyear transition period would allow an unelected body to shape the economics and political institutions of the country with the assistance of Haiti's private sector and the U.S. foreign policy establishment. But, in order to complete a transition to democracy where the poor majority's participation and demands are incidental, the appropriate persons would have to be found to take part in elections.

\section{THE RESPONSIBLE OPPOSITION}

The march towards elections would require the $\mathrm{CNG}$ to allow for the emergence of a political opposition. The question for the CNG was whether it sought to replicate the "Duvalier-style" elections of the past; was willing to open up the political process to segments of a credible opposition whose function would be to moderate the expectations of the population; or would it allow the grassroots organizations to shape Haiti's transition towards democracy? As members of the so-called "responsible opposition" positioned themselves for power as the CNG pushed forward with its efforts to establish polyarchy in Haiti, the popular movement was able to press for its own alternative agenda, to the point of discrediting this opposition and threatening the very existence of the CNG.

While upon Jean-Claude's ouster from power, the international and domestic media instantly began highlighting prominent figures that were sure to be critical to the country's successful transition to democracy, a certain reticence seemed to manifest 
within the CNG. Though favoring the principle of a "right to return" for exiles, Gerard Gourgue thought that the CNG could not ignore the potential risks. So, initially those considered "undesirables" arriving without return visas were sent back immediately by the government's immigration and police services. ${ }^{518}$ Despite the CNG slowing the process of return for many exiles, the received wisdom was that democracy simply could not be established in Haiti without the exiles.

According to the head of the Haitian Confederation of Autonomous Trade Unions exiled in Caracas, Venezuela, George Fortune, Haiti was a decapitated society, and thus "the presence of the overseas-based exiles was essential to the establishment of democracy in Haiti after almost three decades of authoritarian rule by the Duvalier dynasty." ${ }^{519}$ While some rejected the CNG outright as a continuation of the Duvalier regime, calling for the establishment of a provisional government in exile, ${ }^{520}$ others believed that not much more could be expected since most of the "opposition" remained outside of the country. Those who made this argument believed it was necessary to momentarily accept the $\mathrm{CNG}$, which they argued was best positioned to reestablish order. ${ }^{521}$ Once order was reestablished, all the factions of the "responsible" opposition

\footnotetext{
518 "Justice Minister Favors Exiles' Gradual Return," Paris AFP [English Translation], February 18, 1986, Foreign Broadcast Information Service (FBIS) Daily Reports, Latin America, February 19, 1986.

519 "CWC Urges Return of Exiles be Expedited," Bridgetown CANA [English Translation], March 24, 1986, Foreign Broadcast Information Service (FBIS) Daily Reports, Latin America, March 25, 1986.

520 "Opposition in Exile Forms Government," Madrid EFE [English Translation], February 9, 1986, Foreign Broadcast Information Service (FBIS) Daily Reports, Latin America, February 11, 1986.

521 "Haitian Exiles Demand Tontons Macoutes Leave," Panama City La Prensa [English Translation], February 15, 1986, Foreign Broadcast Information Service (FBIS) Daily Reports, Latin America, February $18,1986$.
} 
would be positioned to carry out negotiations on a government program. ${ }^{52}$ Exiled in Venezuela, former François Duvalier Minister of Foreign Affairs, Leslie Manigat, ${ }^{523}$ viewed the presence of General Namphy and Gerard Gourges in the CNG as positive signs for Haiti's democratic transition. The former was "a career officer whose image seems to be that of an independent professional," and the latter, "a human rights advocate who has become minister of justice." ${ }^{524}$ According to Manigat, thousands of followers of his Rassemblement des Democrates Nationaux Progressistes (RDNP) party, along with other Social and Christian Democrats across several Caribbean capitals, were anxious to return to Haiti "to participate in the difficult task of rebuilding the country."

For the popular movement, members of the so-called "responsible opposition," like Manigat, or former Jean-Claude Ministers, Marc Bazin and Hubert de Ronceray, as well as staunch opponents of the Duvaliers, Protestant minister Sylvio Claude, and Louis Dejoie II, whose father ran against Duvalier in the 1957 elections, were "opportunists" and "professional politicians." Following the November 1985 mass protests just before Jean-Claude's ouster, grassroots groups like Kontenjan 28 Jiyè (the July 28th Contingent) distinguished between the masses, who were out in the streets to end misery, and "the opposition," who, while calling for the end of Jean-Claude's presidency-for-life, would

\footnotetext{
522 "Dissident Demands Duvalier Extradition," Paris AFP [English Translation], February 7, 1986, Foreign Broadcast Information Service (FBIS) Daily Reports, Latin America, February 11, 1986.

${ }^{523}$ Rally of Progressive National Democrats

524 "Group Urges Dismantling of Duvalier Structures," Paris AFP [English Translation], February 17, 1986, Foreign Broadcast Information Service (FBIS) Daily Reports, Latin America February 18, 1986. ${ }^{525}$ Ibid.
} 
align themselves with Duvalierists, the dominant classes, and the imperialists if it meant having their turn at power. ${ }^{526}$

As 1987 approached, and elections loomed less far in the distance, various elements of the "responsible opposition" began positioning themselves for office. On December 24, 1986, ten leaders of Haiti's moderate political parties announced the creation of "a 'joint action pact' for the promotion and defense of democracy," pledging "to establish and maintain a regime of pluralist democracy for all political parties without exception, provided that the parties abide by the rules of the democratic game. In particular these rules include the rejection of any political system which does not respect the following: the people's will, as expressed in elections; political and ideological pluralism; or legal opposition and the holding of free, periodic elections." ${ }^{527}$ Amongst the most prominent members of this group were Luis Dejoie of the National Industrial and Agricultural Party (PAIN); Hubert de Ronceray of the Movement for National Development (MDN); Louis Eugene Athis of the Democratic Movement for the Liberation of Haiti (MODELH); Marc Bazin of the Movement for the Establishment of Democracy in Haiti (MIDH); Gregorio Eugene of the Christian Social Party of Haiti (PSCH); and Leslie Manigat of the Union of Progressive National Democrats (RDNP). ${ }^{528}$

\footnotetext{
526 "Ann Fè Rèl Gonayiv ak Lezòt Vil Yo Tounen You Fòs!," Kontenjan 28 Jiyè, Desanm 85/December 85; found in Schomburg Center, Haiti Dechoucaj Collection, Box1, Folder 27 - Background Material, Haitians in NY, Political Leaflets 1980-86.

527 "Moderate Parties Sign 'Joint Action Pact,"' Paris AFP [English Translation], December 24, 1986, Foreign Broadcast Information Service (FBIS) Daily Reports, January 8, 1987.

${ }^{528}$ Ibid.
} 
These parties were at the forefront of demanding that the CNG allow for the creation of a permanent electoral council to organize and supervise the upcoming elections. ${ }^{529}$

From January 31 to February 3, 1987, over 300 popular organizations would similarly come together for the First National Congress of Democratic Movements, in order to establish a national institutional presence for the disparate organizations of the popular movement spread across the country. ${ }^{530}$ For Rene Theodore of PUCH, one of only two formal political parties to take part in the Congress, to establish a real and authentic democracy in Haiti, it would be necessary to form a government stemming from "the people's committees throughout the country, which are the institutions that have truly been created by the popular movement..." ${ }^{\text {531 }}$ According to Theodore, the people did not want traditional style elections, which would only result in the same rulers as in the past, but rather leaders that would "promote and effectively institutionalize the popular movement that had been watching from the sidelines for a long time.."532 Out of this meeting, a national umbrella group would be formed called the Comité National du Congrès des Mouvements Démocratiques (CONACOM), which brought the various local peasant, youth, union, merchant, and women's organizations of the popular movement together, not only to resist Macoutism and Duvalierism, but to define a popular agenda for a democratic future. CONACOM demanded fundamental changes to Haiti's

\footnotetext{
${ }^{529}$ Ibid.

${ }^{530}$ National Coalition for Haitian Refugees, Americas Watch, "Haiti 1987 Election Watch: A Democracy Through Terror," Haitian Dechoukaj Collection, Box 1, Folder 8, 3-4.

531 "Haiti's Theodore on Junta," Havana International Service [English Translation], February 7, 1986, Foreign Broadcast Information Service (FBIS) Daily Reports, Latin America, February 11, 1986.

532 "Interview with Theodore," Havana International Service [English Translation], March 23, 1986, Foreign Broadcast Information Service (FBIS) Daily Reports, Latin America, March 31, 1986.
} 
economic, political, and social life, particularly for the poor, peasant, and working class majority. They called for an end to 'the injustice and exploitation' of peasants, workers, and artisans," "an agricultural policy that would make them self-sufficient in foodstuffs and improve the peasants' condition," agrarian reform, national industry without foreign dependency, an army and police force 'at the service of the people,' the elimination of justice 'only for the rich,' a revaluation of the Creole language, respect for the Vodou religion, and rehabilitation of Haitian traditional medicine. ${ }^{533}$

It is within this context of an increasingly mobilized and organized opposition, that the constituent assembly was emboldened to draft the Constitution of 1987, which would be considered "one of the most liberal constitutions that Haiti has ever had."534 The creation of the 9-member Electoral Council, appointed by government institutions, human rights organizations, the journalists' association, and church representatives, to supervise the upcoming elections, ${ }^{535}$ appealed strongly to the "responsible opposition." So did other provisions, such as the reduction of presidential power vis-à-vis a prime minister chosen from amongst the representatives of the majority party in the legislature, the removal of the president's power to personally select heads of Haiti's armed forces and judiciary, and restrictions on the president's ability to dissolve the legislature. That the new constitution was drafted in Creole, the language of Haiti's poor majority,

\footnotetext{
533 "Democratic Movements Congress Adjourns," Paris AFP [English Translation], February 2, 1987, Foreign Broadcast Information Service (FBIS) Daily Reports, Latin America, February 2, 1987.

534 "Government Takes Steps for Free, Fair Referendum," Bonaire Trans World Radio [English Translation], March 18, 1987, Foreign Broadcast Information Service (FBIS) Daily Reports, Latin America, March 19, 1987.

535 "Constituent Assembly Issues Electoral Rules," Paris AFP [English Translation], February 25, 1987, Foreign Broadcast Information Service (FBIS) Daily Reports, Latin America, February 26, 1987.
} 
alongside the traditional French; called for agrarian reform; and established the separation of the police from the armed forces, particularly the chef section that had traditionally repressed the peasantry, were particularly directed towards the popular movement. ${ }^{536}$

Nevertheless, what truly galvanized the population's support for the Constitution of 1987 in the March 29 referendum was Article 291 barring those who had been "known to have in any way helped or favored the dictatorship established by the Duvalier family" from all elected functions for 10 years. ${ }^{537}$ "The majority of the democratic and progressive sectors, peasant and student organizations, and the Catholic Church urged the population to vote in favor of the new constitution, which redeems the fundamental civil and political rights. ${ }^{538}$ In fact, a number of the most prominent elements of the popular movement, such as CONACOM, representatives from the Ti Legliz and progressive Protestants, and the Patriotic Union Bloc announced that they would create popular brigades to defend the overwhelmingly approved Constitution of 1987 throughout Haiti's towns and rural areas. These brigades would "report to the Provisional Electoral Council [CEP] any violations of the constitution in their respective areas, as well as the candidacy 'for any elected post by any thief or murderer of the overthrown regime.' Those responsible for this movement stressed their determination to guarantee CEP's

\footnotetext{
536 "Government Takes Steps for Free, Fair Referendum," Bonaire Trans World Radio [English Translation], March 18, 1987, Foreign Broadcast Information Service (FBIS) Daily Reports, Latin America, March 19, 1987.

${ }^{537}$ Ibid.

538 "Referendum on Constitution," Havana International Service [English Translation], March 29, 1987, Foreign Broadcast Information Service (FBIS) Daily Reports, Latin America, April 2, 1987.
} 
independence, so the country may have democratic elections according to the spirit of the current constitution. ${ }^{1539}$ This would be the stage set for the upcoming elections.

As it became clear that the $\mathrm{CNG}$ would not be able to maneuver fellow Duvalierists into positions of power through elections, as a result of the CEP, the CNG increasingly sought to weaken, control, discredit, or completely disband it. On June 22, the $\mathrm{CNG}$ would proclaim a new electoral law placing supervision of the upcoming local elections in the hands of the Interior Ministry, eliminating "the supervisory function of the electoral council." ${ }^{540}$ A few days later, the CNG would bar Sed Maseille, representative of the Catholic Church, and Ernst Verdure, representative of the Protestant Church, from sitting on the CEP due to their purported failure to declare their U.S. and Canadian citizenships respectively, ${ }^{541}$ giving the two institutions 48 hours to replace their representatives. ${ }^{542}$ As the CEP refused to step down, accusing the CNG of violating the Constitution, and thus invalidating all elections to be held under the government's new electoral decree, ${ }^{543}$ nine key political candidates announced that they would boycott the upcoming August local elections, as well as the presidential elections in November." ${ }^{544}$

\footnotetext{
539 "Political Brigades Vow to Protect New Constitution," Paris AFP [English Translation], May 26, 1987, Foreign Broadcast Information Service (FBIS) Daily Reports, Latin America, May 28, 1987.

540 "Strikes, Demonstrations Bring Death, Clashes," Madrid EFE [English Translation], July 1, 1987, Foreign Broadcast Information Service (FBIS) Daily Reports, Latin America, July 1, 1987.

541 "Foreigners Barred from National Election Board," Bonaire Trans World Radio [English Translation], June 25, 1987, Foreign Broadcast Information Service (FBIS) Daily Reports, Latin America, June 26, 1987.

542 "Electoral Council Refuses to Step Down," Hamburg DPA [English Translation], June 25, 1987, Foreign Broadcast Information Service (FBIS) Daily Reports, Latin America, June 30, 1987.

${ }^{543}$ Ibid.

544 "1 Dead, 4 Wounded," Bonaire Trans World Radio [English Translation], June 30, 1987, Foreign Broadcast Information Service (FBIS) Daily Reports, Latin America, July 1, 1987.
} 
While, in the midst of this growing political turmoil, the Autonomous Central of Haitian Workers (CATH) announced a labor strike for higher salaries and the repatriation of mistreated Haitian braceros in the Dominican Republic,${ }^{545}$ many suspected the strike was to oppose the CNG's disposition towards the newly established CEP. "Contrary to what had been expected, some political organizations issued appeals against the strike through communiqués published in newspapers and aired on radio and television." ${ }^{546}$ Nevertheless, the general strike would be widely observed without much support from the "responsible opposition." According to a CATH representative, the success of the general strike "shows that the political parties and their so-called leaders are no longer the leaders of the Haitians." ${ }^{547}$ Subsequently, the CNG would order the storming of CATH's offices by the military, the arrest of five of its members, ${ }^{548}$ and the union's dissolution as it was deemed to have "violated the basic principal of all unions, that is, to be essentially apolitical." ${ }^{549}$ This would prompt fifty-seven political organizations to escalate the confrontation with the CNG even further by calling its actions against the CEP a coup d'état and initiating a 24-hour general strike. ${ }^{550}$ Clustering around the umbrella group,

\footnotetext{
545 "National Governing Council Dissolves CATH," Hilversum International Service [English Translation], June 24, 1987, Foreign Broadcast Information Service (FBIS) Daily Reports, Latin America, June 24, 1987.

546 "General Strike Under Way; Streets Heavily Guarded," Madrid EFE [English Translation], June 22, 1987, Foreign Broadcast Information Service (FBIS) Daily Reports, Latin America, June 23, 1987.

${ }^{547}$ Ibid.

${ }^{548}$ Ibid.

549 "Soldier Fatally Wounded Where Union Members Jailed," Bonaire Trans World Radio [English Translation], June 25, 1987, Foreign Broadcast Information Service (FBIS) Daily Reports, Latin America, June 26, 1987.

550 "Strike Called to Protest Voiding of Election Law," Bonaire Trans World Radio [English Translation],
} 
CONACOM, formed earlier in the year by over 300 grassroots organizations, ${ }^{551}$ the entity leading the strike came to be known as the Group of 57.

As the Group of 57 initiated the mass strike on June 29, Interior Minister and member of the CNG, General William Regala made it known that "he would order the repression of any violent act or attack against public property," ${ }^{252}$ sparking violent clashes between the military and protestors across the country. ${ }^{553} 554$ The intensity of the confrontations between the population and the armed forces would prompt General Namphy to publicly reject claims that the CNG had political aspirations. Rather, he accused hostile sectors of "attempting to stop the election process," and called on "the people to help the Armed Forces in the transition toward democracy." ${ }^{555}$ As the Group of 57 declared a break in protests on July 3rd, to mourn the 16 people killed as a result of the military's repressive actions, the streets of Port-au-Prince and the provincial cities would be shaken by the din of posts and pans banging against telephone posts, "a peculiar form of citizen's protest that resemble[d] the actions taken at the beginning of last year

June 27, 1987, Foreign Broadcast Information Service (FBIS) Daily Reports, Latin America, June 29, 1987.

551 "Broad-Based Coalition Stages Protest: '57 Organizations'--New Force in Haiti," Los Angeles Times, July 11, 1987.

552 "Haiti's Regala Threatens to Repress Strike Actions," Havana Radio Reloj Network [English Translation], June 29, 1987, Foreign Broadcast Information Service (FBIS) Daily Reports, Latin America, July $1,1987$.

553 "Strikes, Demonstrations Bring Death, Clashes," Madrid EFE [English Translation], July 1, 1987, Foreign Broadcast Information Service (FBIS) Daily Reports, Latin America, July 1, 1987.

554 "Repression Reported," Havana International Service [English Translation], July 2, 1987, Foreign Broadcast Information Service (FBIS) Daily Reports, Latin America, July 6, 1987.

555 "Clashes Result in 10 Deaths, 57 Injured," Paris AFP [English Translation], July 1, 1987, Foreign Broadcast Information Service (FBIS) Daily Reports, Latin America, July 2, 1987. 
against the dictator, Jean-Claude Duvalier." ${ }^{556}$ In order to quell what appeared to be an escalating mass movement to oust the government, Namphy would declare the annulment of the decree giving the $\mathrm{CNG}$ control of the election process, ${ }^{557}$ while also allowing the union CATH to resume its activities. ${ }^{558}$

Despite what many within the "responsible opposition" viewed as the government's willingness to make concessions, the Group of 57 called for the general strike to resume on July 6th throughout the country, in order to force "the resignation of the National Government Council (CNG), which it accused of being allied with the supporters of Jean-Claude Duvalier." ${ }^{559}$ Instead, the CNG would defiantly reject the Group of 57's call for its resignation, while 35 high ranking officers of the three branches of the Haitian Armed Forces went on radio and television to declare their 'total support' for the CNG. ${ }^{560}$

While the military increasingly came forward to proclaim its support for Namphy and the $\mathrm{CNG}$, divisions between the "responsible opposition" and the popular movement became increasingly evident. On the one hand, the presidential candidates called on the opposition to "show political sobriety" and engage in dialogue with the CNG, fundamentally questioning efforts to replace the Namphy government four months before

\footnotetext{
556 "Day of Mourning Held," Havana Radio Reloj Network [English Translation], July 3, 1987, Foreign Broadcast Information Service (FBIS) Daily Reports, Latin America, July 6, 1987.

557 "CNG Annuls Decree," Paris AFP [English Translation], July 2, 1987, Foreign Broadcast Information Service (FBIS) Daily Reports, Latin America, July 6, 1987.

558 "Government Authorizes CATH to Resume Activities," Paris AFP [English Translation], July 6, 1987, Foreign Broadcast Information Service (FBIS) Daily Reports, Latin America, July 7, 1987.

559 "6 Jul Strike Called," Paris AFP [English Translation], July 5, 1987, Foreign Broadcast Information Service (FBIS) Daily Reports, Latin America, July 6, 1987.

${ }^{560}$ Ibid.
} 
presidential elections. They argued that it would be unwise to "change horses in midstream when one is almost all the way across. ${ }^{561}$ This would be a position strongly supported by U.S. officials, particularly Deputy Assistant Secretary of State for Caribbean Affairs, Richard Holwill, who while in Haiti to meet with the CNG, stated that "elections, not demonstrations, are the way governments are changed in a democracy," warning that the U.S. would suspend economic aid to Haiti if Namphy was forced to resign. ${ }^{563}$

On the other hand, across the popular movement, a radically different sentiment prevailed. For the four major Haitian trade union federations, CATH/CLAT [Autonomous Central of Haitian Workers/Latin American Central Organization of Workers], FOS [Federation of Workers' Unions], and CNEH [National Federation of Haitian Teachers], the CNG's withdrawal of some decrees was "not sufficient to restore the Haitian people's confidence...not as long as all the criminals who murdered the children of the Haitian people remain[ed] in their posts and thus are able to repeat their acts at any time..." ${ }^{564}$ This would foreshadow the Election Day violence that would be carried out by the $\mathrm{CNG}$ and its allies.

\footnotetext{
561 "Paper Views Various Reactions to CNG Decision," Port-au-Prince Le Nouvelliste [English Translation], July 4, 1987, Foreign Broadcast Information Service (FBIS) Daily Reports, Latin America, July $7,1987$.

562 "Broad-Based Coalition Stages Protest: '57 Organizations'--New Force in Haiti," Los Angeles Times, July 11, 1987.

563 "Haitians Demand Namphy, Council Resignation," Havana International Service [English Translation], July 11, 1987, Foreign Broadcast Information Service (FBIS) Daily Reports, Latin America, July 14, 1987.

564 "Trade Unions State Position on Situation," Port-au-Prince Domestic Service [English Translation], July 8, 1987, Foreign Broadcast Information Service (FBIS) Daily Reports, Latin America, July 9, 1987.
} 
For Max Bourjolly, Secretary General of PUCH, the way that the Army appeared on television, coming "forward like a political party, whose government is the National Government Council [CNG]," ${ }^{565}$ highlighted what was likely an ambition of the military to retain power despite their pronouncements to the contrary. While some of the presidential candidates contended that replacing the $\mathrm{CNG}$ as an institution might violate the letter of the Constitution, and others argued that it said nothing about the CNG's composition, ${ }^{566}$ Bourjolly argued that "it is the people who make a Constitution, and it is the people who unmake a Constitution...We trust them to make decisions in conformity with their interests as a people and also with the national interest...." ${ }^{567}$ Similarly, Evans Paul of KID believed "either the country belongs to the people or it belongs to the CNG. If the people are in agreement with the $\mathrm{CNG}$, the $\mathrm{CNG}$ will stay. But if the people say the CNG must go," ${ }^{568}$ then it is their will that must be done. In any case, they viewed the Constitution as a phase; "a moment in the life of the Haitian people," not "something fixed, definitive, untouchable," ${ }^{569}$ that could be used to hamper the will of the people.

As different factions within the opposition sought to offer alternatives to the current military-dominated CNG, again, a rift between the "politicians" and the popular movement appeared. Three politicians from the anti-Duvalier wing of the "responsible

\footnotetext{
565 "PUCH Official on Current Political Situation," Port-au-Prince Domestic Service [English Translation], July 6, 1987, Foreign Broadcast Information Service (FBIS) Daily Reports, Latin America, July 8, 1987.

566 "Paper Views Various Reactions to CNG Decision," Port-au-Prince Le Nouvelliste [English Translation], July 4-5, 1987, Foreign Broadcast Information Service (FBIS) Daily Reports, Latin America, July 7, 1987.

567 "PUCH Official on Current Political Situation," Port-au-Prince Domestic Service, July 6, 1987.

568 "Meeting Called," Port-au-Prince Domestic Service [English Translation], July 9, 1987, Foreign Broadcast Information Service (FBIS) Daily Reports, Latin America, July 10, 1987.

569 "PUCH Official on Current Political Situation," Port-au-Prince Domestic Service, July 6, 1987.
} 
opposition," Sylvio Claude of the Haitian Christian Democratic Party, Bernard Sansaricq of the Haitian People's National Party, and Yves Volel of the Christian Democratic Union, would come together in what they called the Coalition for the Final Struggle (CLF), presenting themselves as leaders of the opposition to the CNG. Their proposed alternative to the CNG, to be headed by 72 year-old vice president of the Court of Cessation, Felix Kavanagh, with Gerard Gourgue as vice-president, and retired General Jean-Baptist Hilaire, as the third member, ${ }^{570}$ would be countered by a proposal from the Group of 57. Instead, the new CNG, as conceived by the Group of 57, would be expanded to five members, to include representatives of the popular movement, such as Claudette Werleigh, head of the CARITAS swine repopulation program, to represent the rural sector, and Gerard Duclervil, a lay member of the Ti Legliz's development programs in Port-au-Prince's poor neighborhoods, to represent the democratic-religious sector. The other three positions would be filled by Felix Kavanagh, from the court of appeals, as previously called for by the CLF, one representative from the Army, and one representative from the human rights organizations. ${ }^{571}$ Even more critical, the Group of 57 proposed the establishment of an interdepartmental council made up of two representatives from each department be formed to assist the CNG with governing. Representatives for this council would be chosen from amongst the multitude of grassroots organizations spread throughout the country. ${ }^{572}$ This proposal reflected the

\footnotetext{
570 "Opposition Coalition Seeks Provisional Government," Paris AFP [English Translation], July 8, 1987, Foreign Broadcast Information Service (FBIS) Daily Reports, Latin America, July 8, 1987.

571 "Opposition Gives Namphy Resignation Deadline," Paris AFP [English Translation], July 9, 1987, Foreign Broadcast Information Service (FBIS) Daily Reports, July 9, 1987.

572 Ibid.
} 
popular movement's emphasis on integrating the grassroots organizations of the poor, peasant, and working classes, into the process of governing, which they had been traditionally excluded.

As Sylvio Claude's attempts to take a leadership position in the movement against the CNG were rebuffed by the Group of 57, and the population as a whole, his antagonism towards the grassroots organizations would become increasingly apparent. Claude felt that given his long history opposing the Duvalier dictatorship, that he should have been the rightful leader of the popular movement. "I am saying, people of Haiti, that I have been fighting on your behalf since $1979 . .$. In 1982-83, I alone was standing up to Duvalier...I was the only opponent to the Duvalier regime. Now, you have shunted me aside. ${ }^{.573}$ What Claude did not understand was that the popular movement that the Group of 57 represented had not chosen candidates yet, nor had it officially determined its participation in the upcoming elections. In fact, according to Gerard Pierre Charles, "the people suspect politicians, and becoming a candidate is in itself a disqualification.... ${ }^{574}$ Though not consisting of groups or leaders with much national profile, the impact of CONACOM and the Group of 57's role in the popular mobilization against Namphy and the CNG would magnify their importance as the congressional and presidential elections approached. ${ }^{575}$

\footnotetext{
573 "Christian Democratic Leader Warns of Communism," Port-au-Prince Domestic Service [English Translation], July 13, 1987, Foreign Broadcast Information Service (FBIS) Daily Reports, Latin America, July 14, 1987.

574 "Pierre Charles Comments on U.S. AID, Elections," Mexico City NOTIMEX [English Translation], May 23, 1987, Foreign Broadcast Information Service (FBIS) Daily Reports, Latin America, May 26, 1987.

575 "Broad-Based Coalition Stages Protest: '57 Organizations'--New Force in Haiti," Los Angeles Times, July 11, 1987.
} 
Feeling that his efforts to galvanize the population against the CNG had been sabotaged, Claude would go on to denounce what he called the communist infiltration of the Group of 57, further distancing himself from the popular movement. He particularly resented Rene Theodore's seeming prominence within the Group of 57, as the head of the Unified Party of Haitian Communists, PUCH, along with a number of leftist organizations. Claude would contend that there were elements within the Group of 57 that were actually seeking to preserve the CNG's dictatorship so as to foster the internal dissention needed for the communist to take power, a refrain that seemed to echo those of the CNG's Henry Namphy. He believed that the Group of 57 was preventing democracy from emerging in Haiti. "Communism will sow division among them so there can be a civil war, so the Communists can seize power...It is where there is no democracy, where there is a dictatorship, that it is able to take power." And thus, according to Claude, the Haitian people were caught between two coups, that of the $\mathrm{CNG}$, or that of the Communists. ${ }^{576}$ And for this, the U.S. was to blame. "If they had aided the democratic sector, given it the logistical means, given it everything it needed to permit it to struggle" rather than keeping the $\mathrm{CNG}$ in power, leftists would not be the dominant force pressing for change. ${ }^{577}$

What this conflict between Sylvio Claude and the Group of 57 revealed was the total detachment of the presidential candidates from the majority of the poor and working

\footnotetext{
576 "Christian Democratic Leader Warns of Communism," Port-au-Prince Domestic Service [English Translation], July 13, 1987, Foreign Broadcast Information Service (FBIS) Daily Reports, Latin America, July 14, 1987.

577 "PDCH Leader Blames U.S. if Country Turns Communist," Port-au-Prince Radio Antilles Internationales [English Translation], July 13, 1987, Foreign Broadcast Information Service (FBIS) Daily Reports, July 15, 1987.
} 
class people that made up Haiti's popular movement. Rather than view the people who made up the popular movement as having agency in their mobilization against the $\mathrm{CNG}$, Claude would depict them, as had Namphy and other purported power brokers, as children being manipulated by "agitators" or "Communists." Rather than conceiving the uprooting of Duvalierism and establishment of democracy in Haiti as requiring the active mobilization of the people across a multitude of grassroots organizations they built for themselves, Claude believed that U.S. actions against the CNG, and in support of the CEP, the political parties, the elections, and perhaps his candidacy, would lead to democracy. To Evans Paul of KID, it appeared that the likes of Sylvio Claude, and other professional politicians, simply could not "place the national interest above a desire for power." 578

\section{DEATH AT THE POLLS}

With or without the "responsible opposition," the Group of 57 and the popular movement it represented would call for a 2 nd phase of the general strike on July 13 , 1987. The Group of 57 called on the Haitian people, particularly the peasants and merchant women, to stop paying taxes and fees to the government; to "stop putting money into the pockets of a government that wastes the people's money by using it to buy weapons for macoutes to kill people with." ${ }^{579}$ Broadening their appeal against the CNG to those outside of the grassroots organizations, they called on all "the people who

\footnotetext{
578 "Democratic Unity Attempts to Eliminate Division," Port-au-Prince Domestic Service [English Translation], July 14, 1987, Foreign Broadcast Information Service (FBIS) Daily Reports, July 15, 1987.

579 "Opposition Calls for Strike to Resume 15 July," Port-au-Prince Domestic Service [English Translation], July 13, 1987, Foreign Broadcast Information Service (FBIS) Daily Reports, July 14, 1987.
} 
represent this $\mathrm{CNG}$ - meaning prefects, magistrates, commissioners information agents, members of the Administrative Councils for the Rural Sections" to resign from their posts to join the popular movement. ${ }^{580}$ They would similarly appeal to the soldiers, whom they argued, came from amongst the people.

In Port-au-Prince a slogan stated the people's struggle is the struggle of all the oppressed and all the soldiers. In Jeremie, in front of the Army headquarters, the people shouted: Soldiers, you are part of the people. Your parents, your brothers, your friends are of the people. They suffer and struggle alongside the people. You have no right to fire against the people. In Les Cayes and Jeremie, the demonstrators repeated over and over: People's Army, it is not true that the popular struggle has not echo in this Army of 7,000 soldiers who earn only $\$ 100$ per month. ${ }^{581}$

As a result of the broadening of the popular movement against the $\mathrm{CNG}$, the Provisional Electoral Council (CEP) would be allowed to publish its 129-article decree establishing the date of presidential elections as November 29, 1987, as well as election guidelines in line with the Constitution of 1987 . The decree formally declared the full independence and autonomy of the CEP as the "supreme electoral tribunal with jurisdiction over the entire country," along with a number of points of particular concern to the "responsible opposition." The decree reduced the residency requirement to run for office to 1 year, allowing those recently returned from exile to participate in elections as candidates. In an attempt to placate the popular movement, the decrees also included a number of provisions intended to convince them to participate in the upcoming elections. The new guidelines allowed for the establishment of "brigades of poll-watchers,

\footnotetext{
${ }^{580}$ Ibid.

581 "Haitian 'Group of 57' Demands Namphy's Resignation," Havana International Service [English Translation], July 14, 1987, Foreign Broadcast Information Service (FBIS) Daily Reports, July 16, 1987.
} 
designated for any given place agreement has been reached following consultation among religious, peasant, workers', and democratic organizations." ${ }^{152}$ Furthermore, the decree stipulated that any candidate previously responsible for public funds would have to be exonerated before running for office, and most importantly, reaffirmed Article 291 of the Constitution of 1987, banning former Duvalierists from public office for 10 years. ${ }^{583}$

While Sylvio Claude issued a statement saying that "nobody—no one at all— should take the risk of organizing elections under the existing provisional National Government Council [CNG]," because the CNG was capable of many underhanded tricks, in his note, he would also emphasize that "under the Constitution, in Article 31-1, it says that all candidates must come from a political party." ${ }^{384}$ Though not clear whether this was directed at persons within the CNG, or at the Group of 57, it did reveal that he still had his eye on possible elections. Conversely, the Group of 57 took an unequivocal, and particularly moral, position against any elections while the CNG was still in power. "The Group of 57 called on the population to do nothing, "not participate in elections or anything else — under this macoute government, which is a totally dependent flunky of a foreign government and which pays no attention to anything the Haitian people ask of it." ${ }^{585}$ According to the Group of 57, the people could not support a government that

\footnotetext{
582 "CEP Sets Guidelines for November Elections," Port-au-Prince Radio Metropole [English Translation], July 15, 1987, Foreign Broadcast Information Service (FBIS) Daily Reports, Latin America, July 16, 1987. ${ }^{583}$ Ibid.

584 "PDCH Issues Note on Organization of Elections," Port-au-Prince Radio Lumiere Network [English Translation], July 16, 1987, Foreign Broadcast Information Service (FBIS) Daily Reports, Latin America, July 20, 1987.

585 "Calls for Support," Port-au-Prince Radio Lumiere Network [English Translation], July 16, 1987, Foreign Broadcast Information Service (FBIS) Daily Reports, Latin America, July 17, 1987.
} 
would rather allow contraband in the form of "Miami Rice" to destroy Haiti's agriculture, and shuts down Haitian factories in the name of foreign interests, rather than promote true development. ${ }^{586}$ Instead, popular organizations of all stripes would mobilize their people to go to the streets against the $\mathrm{CNG}$, and who they believed was keeping it in power, the United States.

The National Federation of Haitian Students, the Committee For a Clearer Vision, and the Union of Port-au-Prince Students organized protests in front of the U.S. Consulate, where young people shouted "Down with Reagan, down with Reagan!", demanding that the U.S. Government stop meddling in Haitian affairs by continuing its support for the CNG and Namphy. ${ }^{587}$ Similar protests, linking the CNG's refusal to step down from power, and increased willingness to use force against the population, to the U.S., would be organized by other grassroots organizations. A mass rally on Charlemagne Peralte Square in Port-au-Prince, organized by the People's National Assembly, reflected on what the July 28, 1915 start of the U.S. occupation of Haiti meant to the country's poor and working class masses of 1987 . The rally would specifically highlight the complicity of "the upper class, and the too-often opportunistic middle class composed of intellectuals," who "threw in their lot with the Yankee Americans to exploit the country," ${ }^{588}$ pointing to the actions of Haiti's current Minister of Finance and

\footnotetext{
${ }^{586}$ Ibid.

587 "Students, Women Hold Antigovernment Demonstrations," Port-au-Prince Domestic Service [English Translation], July 21, 1987, Foreign Broadcast Information Service (FBIS) Daily Reports, Latin America, July 23, 1987.

588 "Anti-American Protests to be Held 28 July," Port-au-Prince Radio Antilles-Internationales [English Translation], July 24, 1987, Foreign Broadcast Information Service (FBIS) Daily Reports, Latin America, July 28, 1987.
} 
Economy, Leslie Delatour, as doing the same. The People's National Assembly, identified closely with the Ti Legliz, would be joined by a number of other grassroots organizations in calling to the poor and working classes to resist now, just as they had resisted then during the caco rebellions of Charlemagne Peralte. ${ }^{589}$ As the tension between the military and protestors, particularly in the poorest communities of Port-auPrince and the provincial cities, escalated, they would call on the people to organize themselves into self-defense brigades. ${ }^{590}$

Rejecting the notion that Haiti faced the threat of U.S. imperialism, General Namphy would declare the greatest threat to country at the moment to be those who attacked the integrity of the Haitian nation from within, committing excesses as the CNG sought to lead the people down the difficult path to democracy. "In these troubled times, when blind and unbridled passions seem to take precedence over reason, when freedom of speech is too often confused with verbalism and with incitement to riot, it is the responsibility of the Armed Forces to enforce respect for republican discipline." ${ }^{591}$ These statements to the Military Academy in Port-au-Prince would signal a shift towards an "undeclared war between the opposition and the military." ${ }^{, 592}$ Increasingly, even the most

\footnotetext{
589 "Groups Participate in Rally," Port-au-Prince Domestic Service [English Translation], July 28, 1987, Foreign Broadcast Information Service (FBIS) Daily Reports, Latin America, July 29, 1987.

590 "Haitian 'Group of 57’ Demands Namphy’s Resignation," Havana International Service [English Translation], July 14, 1987, Foreign Broadcast Information Service (FBIS) Daily Reports, Latin America, July 16, 1987.

591 "Namphy Reaffirms Military Commitment to People," Port-au-Prince Domestic Service [English Translation], July 17, 1987, Foreign Broadcast Information Service (FBIS) Daily Reports, Latin America, July 20, 1987.

592 "Further on Demonstrations," Hamburg DPA [English Translation], July 30, 1987, Foreign Broadcast Information Service (FBIS) Daily Reports, Latin America, July 31, 1987.
} 
peaceful of demonstrations would face point-blank fire by the army. ${ }^{593}$ Throughout provincial cities of Les Cayes, Cap-Haitien, Jeremie, and Jacmel, the level of repression was even more egregious. The homes of those identified with the popular organizations, or even the political parties, were burned, while hundreds of others were being arrested without ever appearing in court. There was a fear that many may have been executed or disappeared. ${ }^{594}$ Amongst the most troubling incidents in this context of growing repression occurred in the remote rural region of Haiti's northwest, the massacre of over 235 people from the peasant organization Tèt Kole by those affiliated with the local landowning elites and allies of the Duvalier regimes. ${ }^{595}$

As the media reported on the growing repressiveness of the $\mathrm{CNG}$, it also came under attack. On July 29, six of the country's main radio stations (Radio Antilles International, Radio Metropole, Radio Haiti Inter, Radio Cacique, Radio Caraibes, Radio Soleil), were machine-gunned because of their insistence on maintaining coverage of the confrontation between the popular movement and the military. ${ }^{596}$ "A newsman, whose care was hit by soldiers' bullets, commented last Wednesday that 'we are being harassed because we are in the places where action takes place and because we are the only ones, along with photographers, who can record civilian casualties when the Armed Forces

\footnotetext{
593 "Group of 57 Calls for Total Success of Strike," Port-au-Prince Radio Lumiere Network [English Translation], July 30, 1987, Foreign Broadcast Information Service (FBIS) Daily Reports, Latin America, July 31, 1987.

${ }^{594}$ Ibid.

595 "Deaths Reportedly High," Madrid EFE [English Translation], July 26, 1987, Foreign Broadcast Information Service (FBIS) Daily Reports, Latin America, July 27, 1987.

596 "News Media 'Targeted' by Army," Paris AFP [English Translation], August 1, 1987, Foreign Broadcast Information Service (FBIS) Daily Reports, Latin America, August 5, 1987.
} 
shoot."' ${ }^{597}$ The military also intimidated foreign press, barging into the hotel rooms for foreign correspondents to seize their footage and documentation of military violence against protestors. "The soldiers were especially looking for the videotape of [an] incident in which the soldiers fired at demonstrators, scenes filmed and broadcast by the U.S. network CBS." ${ }^{598}$ Asked about the growing assaults on the press by the military, the CNG's Information Minister Noel would go on to state that, "the press, too, is guilty of misinformation...They need these [foreign] journalists to say, abroad, that we beat people, that we assassinated so-and-so, that so-and-so was murdered..." ${ }^{599}$

In this new context of unbridled repression, the military increasingly targeted members of the opposition with either expulsion or assassination. On August 2nd, 1987, 46-year-old founder of the Democratic Movement for Haitian Liberation (MODELH) party, Louis Athis, would be killed in a rural section of Leogane as he prepared for a meeting. Charged by local Duvalierists as a communist, "a group of people armed with machetes, clubs, and rocks attacked the MODELH leader." This caused a considerable stir since Athis was a leading member of the centrist coalition group, the Democratic Center, which included "Louis Dejoie, Marc Bazin, Leslie Manigat, and other leading candidates for the Haitian presidency...." ${ }^{600}$ The Group of 57 would suspend the strike, to

\footnotetext{
${ }^{597}$ Ibid.

598 "Blames Cuban-Trained Persons," Paris AFP [English Translation], July 31, 1987, Foreign Broadcast Information Service (FBIS) Daily Reports, Latin America, August 3, 1987.

599 "Information Minister Noel Discusses Recent Violence," Port-au-Prince Domestic Service [English Translation], July 31, 1987, Foreign Broadcast Information Service (FBIS) Daily Reports, Latin America, August 5, 1987.

600 "Opposition Leader Louis E. Athis Killed 2 Aug," Paris AFP [English Translation], August 3, 1987, Foreign Broadcast Information Service (FBIS) Daily Reports, Latin America, August 4, 1987.
} 
spare the population from suffering. ${ }^{601}$ On August 3, 1987, the CNG would expel Daniel Narcisse, one of the leaders of the Group of $57 .{ }^{602}$

\section{CONCLUSION}

As of the grassroots poor, peasant, and working class organizations were able to develop an increasingly unified national presence through the establishment of the umbrella group CONACOM, the political landscape in Haiti was drastically altered for elements of the "responsible opposition" who perhaps hoped that their prominence in national and international political and intellectual circles would propel them to power in elections managed by the CNG. As CONACOM, and later, the Group of 57, increasingly appeared as the most democratic political organizations at the national level, their support for the Constitution of 1987 became indispensible to its moral force. So, the constituent assembly, closely aligned with the "responsible opposition," included provisions in the Constitution that would give it popular legitimacy. With the population displaying overwhelming support for the Constitution in an internationally recognized referendum, it could then be used as a shield to protect these politicians from the CNG and other antidemocratic forces, as they participated in elections.

What the "responsible opposition" did not anticipate was the backlash that the CNG would show towards Article 291 of the Constitution of 1987, barring supporters of Duvalier from public office for 10 years. As the "responsible opposition" depended on

\footnotetext{
601 "Haitian Democratic Front Calls Off Strike," Havana Radio Rebelde Network [English Translation], August 1, 1987, Foreign Broadcast Information Service (FBIS) Daily Reports, Latin America, August 4, 1987.

602 "Democratic Front Suspends Strike; Climate 'Tense,"' Madrid EFE [English Translation], August 3, 1987, Foreign Broadcast Information Service (FBIS) Daily Reports, Latin America, August 4, 1987.
} 
support from the U.S., that did not come, to counter the growing authoritarianism of the CNG, it was CONACOM and the Group of 57 that were able to challenge the CNG due to their strong linkages to the various grassroots organizations around the country. So, as the Group of 57 called for the population to escalate the mobilization against Namphy and the $\mathrm{CNG}$, and it became clear that the "responsible opposition" could not contain the popular sector, the regime increasingly abandoned the minimum requirements for establishing polyarchy in order to push forward the manipulated elections of Duvalier past. The results would be the violently cancelled presidential election of November 1987, and the subsequently rigged elections of 1988. 


\section{CHAPTER V. \\ MANIGAT'S GAMBLE \\ INTRODUCTION}

The selection of Leslie Manigat in the military-controlled elections of January 17, 1988 reflected the determination of the Duvalierist military hierarchy, led by Henri Namphy, to dictate the terms and parameters of Haiti's transition to polyarchy, and the Reagan administration's willingness to accept this in the face of the poor and working classes' growing grassroots mobilization for popular democracy.

This chapter examines efforts by the U.S. and its regional surrogates to obfuscate the role of the military and the $\mathrm{CNG}$ in orchestrating the election-day violence, framing the events in terms of an ideological confrontation between extremes of the left and right in Haiti. It specifically analyzes U.S. efforts to convince the "responsible opposition" to participate in the manipulated January 1988 elections, and to legitimize the short-lived presidency of Leslie Manigat.

\section{FINDING A MINIMAL CONSENSUS}

Following the November 29, 1988 election-day massacre, Namphy and the military hierarchy sought to establish a new consensus whereby the role of Duvalierists in the country's political and economic life would be secured. For Namphy, "the historic commitment" that should have been made on November 29 could still be made. "The worst was not 'inescapable' because a consensus, 'even a minimal one,' [could] be 
achieved and bare good fruit." ${ }^{603}$ To establish this minimal consensus, Namphy sought to shift influence within the "responsible opposition" from those that sought to align themselves with the mobilized population to exclude Duvalierists from political power, and possibly prosecute the most reprehensible supporters of the ousted regime, to elements within the opposition that were willing to share power alongside Duvalierists, particularly in a subservient position.

The first step in this process was to issue a decree dissolving the CEP, accusing it of "having set itself up as a 'supreme power'..." ${ }^{004}$ The CNG later "noted in a communique that the CEP [had] not been dissolved and [would] continue to exist as a constitutional institution," ${ }^{605}$ but with individuals not antagonistic to the CNG or Duvalierists more broadly. "In contempt of the Constitution, which it continually violated, the provisional CNG has dismantled the CEP...to form their own CEP to hold their own elections." ${ }^{1606}$ The nine persons appointed to the CEP would be wholly unfamiliar to the population, signaling their complete detachment from both the "responsible opposition" and the grassroots popular movement. ${ }^{607}$ "They swore to be totally impartial, taking no side; and to fulfill their mission with dignity, fully respecting

\footnotetext{
603 "Namphy Calls for 'Historic Commitment,"' Paris AFP [English Translation], January 1, 1988, Foreign Broadcast Information Service (FBIS) Daily Reports, Latin America, January 4, 1988.

604 "CNG Dissolves CEP," Paris AFP [English Translation], November 29, 1987, Foreign Broadcast Information Service (FBIS) Daily Reports, Latin America, November 30, 1987.

605 "Namphy Reproaches CEP," Paris AFP [English Translation], November 30, 1987, Foreign Broadcast Information Service (FBIS) Daily Reports, Latin America, November 30, 1987.

606 "PUCH's Bourjolly on Anticommunist Campaign," Port-au-Prince Radio Nationale, December 10, 1987, Foreign Broadcast Information Service (FBIS) Daily Reports, Latin America, December 11, 1987.

607 "CNG Appoints Provisional Electoral Council," Paris AFP [English Translation], December 12, 1987, Foreign Broadcast Information Service (FBIS) Daily Reports, Latin America, December 14, 1987.
} 
the Constitution and all dispositions of the electoral decree." ${ }^{608}$ Impartial was a code word for not excluding past supporters of the Duvalier regimes from running for office in the upcoming elections.

Nevertheless, the hope was to find a figure that would be palatable to the United States, and even perhaps segments of the "responsible opposition," without fundamentally threatening to the $\mathrm{CNG}$ and Duvalierists. So, the new CEP president made it clear that while "he regretted that the members of the Constitutional Assembly of 1987 had put such an article in the Constitution because he personally did not find it fair,"609 the CEP would "not ignore Article 291 barring fervent Duvalierists, but [would] ensure to apply the article properly." ${ }^{610}$ Subsequently, the most problematic Duvalierist candidates, like former finance minister under François Duvalier, Clovis Desinor, and former chief of staff, and later interior and national defense minister under François and Jean-Claude, Claude Raymond, would be excluded. ${ }^{611}$ "Western diplomats and many Haitians say the rejection of the Duvalier associates, in accordance with a constitutional provision that bars key figures from the dictatorship from public life for 10 years, served...to give the

\footnotetext{
608 "New Provisional Electoral Council Sworn In," Port-au-Prince Radio Nationale [English Translation], December 14, 1987, Foreign Broadcast Information Service (FBIS) Daily Reports, Latin America, December 15, 1987.

609 "Position Clarified," Port-au-Prince Radio Nationale [English Translation], January 8, 1988, Foreign Broadcast Information Service (FBIS) Daily Reports, Latin America, January 11, 1988.

${ }^{610}$ Ibid

611 "CEP Eliminates 8 Presidential Candidates," January 10, 1988, Foreign Broadcast Information Service (FBIS) Daily Reports, Latin America, January 11, 1988.
} 
election a measure of credibility..." ${ }^{612}$ The belief amongst the opposition was that "the CNG agreed to allow Article 291's application under foreign pressure..." ${ }^{613}$

The two most prominent of the presidential candidates to participate in the January 17 elections, had historical ties to the Duvalier regimes, but were in a position to claim to have rejected the more reprehensible aspects of these governments. Of note was "Hubert de Ronceray, a sociologist and former minister of Jean-Claude Duvalier who went over to the opposition and who is also the founder of the Mobilization for National Development [MDN]." ${ }^{614}$ De Ronceray argued that his party was "still the only group able to bridge the gap between absolute power, which is the inheritance of a former system, and...a dictatorship of the proletariat." ${ }^{615}$ Leslie Manigat was another to send the right signals to the $\mathrm{CNG}$ and other Duvalierists. Manigat believed that "the Army remain[ed] a reality you cannot get around. If you try to send the Army back to the barracks by force, there will be a coup d'etat or civil war," ensuring that "a harder line would have every chance of prevailing." ${ }^{616}$ Instead, "the Army had to be brought into the

\footnotetext{
${ }^{612}$ Joseph B. Treaster, "Strike and Boycott Are Urged in Haiti," New York Times, January 15, 1988.

613 "PUCH Calls for Election Postponement," Port-au-Prince Radio Metropole [English Translation], January 12, 1988, Foreign Broadcast Information Service (FBIS) Daily Reports, Latin America, January 13,1988 .

614 "Electoral Campaign Officially Opens 22 Dec," Port-au-Prince Radio Metropole [English Translation], December 23, 1987, Foreign Broadcast Information Service (FBIS) Daily Reports, Latin America, December 24, 1987.

615 "Hubert de Ronceray Reaffirms Candidacy," Port-au-Prince Radio Nationale [English Translation], December 16, 1987, Foreign Broadcast Information Service (FBIS) Daily Reports, Latin America, December 17, 1987.

616 "Leslie Manigat to Run," Port-au-Prince Radio Metropole [English Translation], December 31, 1987, Foreign Broadcast Information Service (FBIS) Daily Reports, Latin America, January 4, 1988.
} 
democracy." ${ }^{617}$ Manigat's vision was "to democratize and modernize the Armed Forces and put it at the service of development." ${ }^{618}$ But, in order to do this, he believed "there had to be a government capable of carrying on a dialogue with the Army." ${ }^{619}$ Dialogue particularly meant absolving the military regime of its past crimes. "Regarding the 19 November massacres, Manigat said that he trust[ed] the Investigating Commission appointed by the National Government Council $(\mathrm{CNG})$ and refused to believe that the Army had a share of responsibility in it..." ${ }^{620}$

Manigat similarly positioned himself as the candidate to bridge the gap between democracy and Duvalierism. "Asked about de-Duvalierization, he announced that his government would not engage in witch-hunts." ${ }^{621}$ According to Manigat, "for 30 years, people had to compromise to survive." ${ }^{622}$ More importantly, he believed that the Duvalier regime represented a significant political line in the country's history that could not be ignored or pushed aside. "A political line could not just disappear overnight in a country, especially not in Haiti, where a particular political line dominated the political scene for

\footnotetext{
617 "Manigat on Duvalierism, Reform, Military Role," Port-au-Prince Radio Metropole [English Translation], February 3, 1988, Foreign Broadcast Information Service (FBIS) Daily Reports, Latin America, February 5, 1988.

618 "Leslie Manigat to Run," Port-au-Prince Radio Metropole, December 31, 1987.

${ }^{619}$ Ibid.

620 "Called Man of the Moment," Paris AFP [English Translation], January 24, 1988, Foreign Broadcast Information Service (FBIS) Daily Reports, Latin America, January 25, 1988.

621 "President-Elect Holds First News Conference," Port-au-Prince Radio Metropole [English Translation], January 26, 1988, Foreign Broadcast Information Service (FBIS) Daily Reports, Latin America, January 27, 1988.

${ }^{622}$ Ibid.
} 
30 years," ${ }^{623}$ using the example of fascism in Italy to say that he thought it normal that Duvalierism as an ideology should continue in Haiti. ${ }^{624}$ In his opinion "Duvalier's message in 1957 corresponded to something real and profound in Haiti," ${ }^{625}$ specifically the noiriste position that the black majority, led in particular by the black middle, should direct the country's political and economic development. Manigat himself came from a black middle-class family of "educators and politicians," whose origins were in Haiti's north. His grandfather, former general and presidential candidate, would be exiled as ambassador to France in the late 1800 s. ${ }^{626} \mathrm{He}$ was in fact an "early supporter of the dictator François 'Papa Doc' Duvalier and voted for him as president in 1957."627 However, he became disillusioned with Duvalierism as this message became deformed, with "the will to promote the peasantry and bring it into the mainstream of society turned into the exploitation of the peasant; the forces that should have been people's forces...transformed into repressive forces." ${ }^{628}$ Though disappointed by the Duvaliers' rule, he rejected vengeance against Duvalierists, and instead spoke of democratizing the Duvalierist line.

\footnotetext{
623 "Manigat on Duvalierism, Reform, Military Role," Port-au-Prince Radio Metropole [English Translation], February 3, 1988, Foreign Broadcast Information Service (FBIS) Daily Reports, February 5, 1988.

${ }^{624}$ Ibid.

625 "Manigat on National Reconciliation Policy," Port-au-Prince Le Progressiste Haitien [English Translation], April 28, 1988, Foreign Broadcast Information Service (FBIS) Daily Reports, Latin America, May 2, 1988.

${ }^{626}$ Jacqueline Charles, "Former Haiti President Leslie Manigat Dead at 83, Miami Herald, June 27, 2014.

627 Ibid.

628 "Manigat on National Reconciliation Policy," Port-au-Prince Le Progressiste Haitien, April 28, 1988.
} 
Both De Ronceray and Manigat presented themselves as alternatives to continued confrontation with the Duvalierists, which they believed would lead to a more repressive military dictatorship, a leftist revolution, and as a result of either, an occupation by the United States. "Admitting that this was a calculated risk...[Manigat] felt the ballot was the only peaceful and rapid means of escaping the current situation." ${ }^{629}$ He asked the "people not to be taken in by slogans implying that to vote means to be pro-CNG," contending that voting in the January 1988 elections constituted a "patriotic obligation." ${ }^{630}$ This was framed as particularly the case in light of statements by Democratic Senator from New York, Patrick Moynihan, in support of "intervention in Haiti by a multinational force so that free elections can be held..." ${ }^{631}$ De Ronceray and Manigat sought to position themselves as the nationalist alternatives to elements of the "responsible opposition," like Louis Dejoie, who declared that "90 percent of the Haitian people would welcome an intervention by a multinational foreign force," 632 echoing Namphy, who claimed that the dismissed CEP had committed "high treason" against the Haitian people, ${ }^{633}$ for having invited foreigners "to meddle in Haitian domestic affairs...an affront to our dignity as a free and sovereign people." ${ }^{634}$ De Ronceray would call those in support of international

\footnotetext{
${ }^{629}$ "Leslie Manigat to Run," Port-au-Prince Radio Metropole, December 31, 1987.

${ }^{630}$ Ibid.

631 "De Ronceray Comments on Moynihan Proposal," Port-au-Prince Radio National [English Translation], January 7, 1988, Foreign Broadcast Information Service (FBIS) Daily Reports, Latin America, January 12, 1988.

${ }^{632}$ Ibid.

633 "CEP Officials Seek Embassy Protection," Hamburg DPA [English Translation], November 30, 1987, Foreign Broadcast Information Service (FBIS) Daily Reports, Latin America, December 1, 1987.

634 "Namphy Reproaches CEP," Paris AFP [English Translation], November 30, 1987, Foreign Broadcast
} 
intervention, a "group of frustrated characters who cannot be president, the people who throughout history have always tried to sell out the country or give it away in order to further their personal interests or the interests of their particular group, ${ }^{1635}$ while using the international community's past support for dictatorship in Haiti to highlight the hypocrisy of the notion that this same international community would support free and fair elections in Haiti:

We see they are talking to us about elections in Haiti, elections they would hold for us...We wonder why today international forces want to come hold elections for us here in Haiti, whereas when we here were fighting to get rid of the dictatorship, all the bigshots told us they would not intervene in the internal affairs of a country. Back then, they all felt that Jean-Claude Duvalier, that the Duvalierists, were an internal Haitian matter and they should not meddle... ${ }^{636}$

The positions of De Ronceray and Manigat, as contrasted to that of Louis Dejoie, stood in contrast to the grassroots movement, which rejected both military-rigged elections to place a pro-Duvalierist puppet in power, or elections conducted under the supervision of an international force to place one amongst the members of the "responsible opposition" in power. Instead, grassroots organizations like the APN and ANOP called for mass mobilization against the current regime. Pressure from the grassroots organizations would push the CED, which Dejoie was a member of, to issue a communiqué stating their position unequivocally against international intervention. ${ }^{637}$

\footnotetext{
Information Service (FBIS) Daily Reports, Latin America, November 30, 1987.

635 "De Ronceray Comments on Moynihan Proposal," Port-au-Prince Radio National, January 7, 1988.

${ }^{636}$ Ibid

637 "CED Issues Communique Against Intervention," Port-au-Prince Radio Soleil Network [English Translation], January 11, 1988, Foreign Broadcast Information Service (FBIS) Daily Reports, Latin America, January 12, 1988.
} 


\section{ELECTIONS BY ANY MEANS}

While U.S. military and other non-humanitarian aid was suspended, Namphy and the military hierarchy calculated that the Reagan administration would be willing to accept their "minimal consensus," allowing the Haitian military to manage the country's transition to a nominally elected civilian government, and to remain in the background to check the potential growth of a radical mass movement. "Despite evidence that elements of Haiti's armed forces were involved in violence that forced the cancellation of presidential elections, the United States [was] still looking to the military to get the elections back on track, Administration officials and foreign diplomats say...There [was] a strong belief in some circles in the Administration that the military [was] the only organized institution in Haiti capable of bringing about an election." ${ }^{638}$

So, despite the four most prominent presidential candidates ${ }^{639}$ forming a pact called le Comite de L'Entente Democratique (the Committee of Democratic Understanding, CED) ${ }^{640}$ to declare that they would boycott any elections carried out by the $\mathrm{CNG}$, the Reagan administration hoped to convince them otherwise. To provide the military-run elections with some added legitimacy, "U.S. Deputy Assistant Secretary of State for Caribbean Affairs Richard Holwill was quoted...as saying U.S. and other foreign diplomats were trying to persuade the opposition to join the elections and field a single

\footnotetext{
${ }^{638}$ Elaine Sciolino, "U.S. Looks to Haitian Military to Restore Elections," New York Times, December 3 , 1987.

${ }^{639}$ Marc Bazin of the MIDH, Sylvio Claude of PDCH, Louis Dejoie of PAIN, and Gerard Gourgue of the FNC.

640 "Bazin, Gourgue, Dejoie, Claude Meet Press," Port-au-Prince Radio Metropole [English Translation], December 22, 1987, Foreign Broadcast Information Service (FBIS) Daily Reports, Latin America, December 23, 1987.
} 
candidate." ${ }^{641}$ While Marc Bazin considered the possibility, stating that he had "no objections to a formula, as long as it can bring about democracy, economic progress, and social justice for Haiti," ${ }^{642}$ on the opposing end within the CED would be Louis Dejoie, who declared Holwill's statement "inconsiderate, foolish and irresponsible." ${ }^{143}$ Dejoie felt that the U.S. was acting inconsistently, asking the opposition to participate in elections that could potentially be rigged, undermining "the valid patriotic actions taken by the majority of the Haitian people through its four most popular leaders..." ${ }^{644}$

As the CED wrestled with the possibility of fielding a single candidate in the January 1988 elections, nearly 50 organizations of a variety of political orientations, including Conacom, representing hundreds of grassroots organizations throughout the country; CATH, CATH-CLAS, and FOS, representing Haiti's largest labor organizations; the Fraternity of Committed Laymen, Frala, representing the Ti Legliz; and the Movement of Volunteers for Free Elections in Haiti (Movelh), founded by one of the crafters of the Constitution of 1987, Dr. Louis Roy, "issued a message entitled Manifesto of the Haitian People in Favor of Democracy" declaring "invalid any election held under the current CNG..."645

\footnotetext{
641 "Dejoie on Call for Opposition Candidate," Paris AFP [English Translation], December 28, 1987, Foreign Broadcast Information Service (FBIS) Daily Reports, Latin America, December 28, 1987.

642 "Bazin on Possibility of Single Candidate," Port-au-Prince Le Nouvelliste [English Translation], December 17, 1987, Foreign Broadcast Information Service (FBIS) Daily Reports, Latin America, December 24, 1987.

643 "Dejoie on Call for Opposition Candidate," Paris AFP, December 28, 1987.

${ }^{644}$ Ibid.

645 "Civilian Organizations Issue Manifesto," Port-au-Prince Radio Metropole [English Translation], January 4, 1988, Foreign Broadcast Information Service (FBIS) Daily Reports, Latin America, January 5 , 1988.
} 
Nevertheless, Gerard Philippe Auguste of the Mouvement Ouvrier Paysan (MOP) argued that "rather than the humiliation of asking for one form or another of foreign intervention or abstention--both of which are unpatriotic decisions--the MOP chooses conditional participation." ${ }^{646}$ At the head of Daniel Fignole's historic political party, rooted in the poor and working class struggle against Duvalierism, Auguste, the 64-year old agronomist and UN expert who lived in exile in Africa during the dictatorship, perhaps felt that he would be able to present himself as the most popular choice in a field of mostly Duvalierists. Instead, Auguste's decision to participate in the January elections opened a major fissure within the MOP, leading to a new breakaway party called the Daniel Fignole Workers and Peasants Front (Front Daniel Fignole Ouvrier-Paysan), which declared "that the front's members [were] not seeking any elected office at this time" nor "support any candidates in the coming 17 January elections." ${ }^{167}$ MOP youth organizations throughout the capital would make an even more forceful statement, declaring that macoutes had infiltrated the party, and were moving it in a direction counter to the legacy of its founder, Daniel Fignole, who "never allowed unscrupulous politicians to carry out underhanded dealings at the expense of the people." 648

\footnotetext{
646 "MOP's Gerard Philippe Auguste to Run," Port-au-Prince Radio Nationale Creole [English Translation], January 5, 1988, Foreign Broadcast Information Service (FBIS) Daily Reports, Latin America, January 7, 1988.

647 "New Workers, Peasants Front Party Created," Port-au-Prince Radio Soleil Network [English Translation], January 6, 1988, Foreign Broadcast Information Service (FBIS) Daily Reports, Latin America, January 7, 1988.

648 "MOP Youth Not to Participate in Elections," Port-au-Prince Radio Metropole [English Translation], January 8, 1988, Foreign Broadcast Information Service (FBIS) Daily Reports, Latin America, January 11, 1988.
} 
What this made clear, was that any candidate that broke away from the majority of the "responsible opposition" and the grassroots organizations to participate in the elections, would be permanently sullied politically, even Marc Bazin, who would also come to speak against elections. Asked whether or not the elections would be valid from a constitutional point of view if only $1 \%$ of the population participated, Bazin said yes, but not from a political point of view. "If you take the position of governing with such an infinitesimal fraction of the electorate, this means you have turned your back on democracy once and for all, that democracy is just an empty word, that the consent of the governed is not necessary..." ${ }^{649} \mathrm{He}$ would even criticize the U.S. for attempting to push the elections forward despite their mass boycott by the population, arguing that "it looks to me like the Americans are perfectly willing to live with a semblance of a president, a semblance of an election, as long as it enables them to save face." ${ }^{160}$ The CED would come to issue a statement castigating any politician who agreed to take part in the CNG's electoral farce:

To those who, out of frenzied ambition, inordinate pride, or naïveté insist on waging, drearily, a diffident and pointless campaign we say: Democracy is not built together with those who practice contempt for life; nor justice with those who are greedy for privileges; nor progress with the supporters of an aberrant and contemptible system which, after 30 years, is synonymous with abject poverty, terror, and humiliation. ${ }^{651}$

As the Reagan administration struggled to get the CED to take part in the January 1988 elections, and thus provide it with some semblance of legitimacy, it relied on proxy

\footnotetext{
649 "CED Communique, Bazin on Elections," Port-au-Prince Radio Metropole [English Translation], January 13, 1988, Foreign Broadcast Information Service (FBIS) Daily Reports, Latin America, January 14, 1988.

${ }^{650}$ Ibid.

${ }^{651}$ Ibid.
} 
governments throughout the Caribbean, particularly that of Jamaica's Edward Seaga, to prevent a unified regional response against the upcoming elections, and the civilian government to follow. Jamaica under Seaga was one of the U.S.'s closest allies in the Caribbean ${ }^{652}$ Upon being elected in 1980, "Seaga broke off Jamaica's diplomatic relations with Cuba, arguing that this was necessary to contain the spread of Cuban communist influence in the Caribbean. His government defended the U.S. invasion of Grenada in 1983 on the same grounds..." ${ }^{653}$ According to the leader of St. Lucia's small left-leaning Progressive Labour Party (PLP), George Odlum, Jamaica's Seaga was the head of "a grouping of right-wing ruling political parties in the region" called the Caribbean Democratic Union (CDU). According to Odlum, the allure of the CDU for many Caribbean political figures was "the provision of funding and assistance in promoting the electoral politics of right wing parties with a pro-American stance. But the corollary to this is that the CDU is primarily concerned with advancing the geopolitical interests of the U.S." ${ }^{654}$ In the case of Haiti, it is important to note that Seaga's government had been instrumental in negotiating the departure of Jean-Claude Duvalier and passing of power to the CNG in 1986. Seaga would attempt to play a similar role in facilitating a transition from the $\mathrm{CNG}$ to a nominally elected civilian government.

Nearly immediately after the November 29, 1987 election-day violence, a group of Caribbean leaders led by Jamaica's Seaga, met in Miami, Florida to discuss how best

\footnotetext{
${ }^{652}$ Ronald T. Libby, "The United States and Jamaica: Playing the American Card," Latin American Perspectives 17, no. 1, Caribbean Crisis and Global Restructuring (Winter, 1990), 89. 1988, Foreign Broadcast Information Service (FBIS) Daily Reports, Latin America, January 14, 1988.
} 
they could "assist Haiti in whatever way possible to establish a firm time-table for elections...[and] to establish contact with the Government of Haiti to offer support for the holding of new elections..." ${ }^{655}$ The group, which included John Compton of St. Lucia, Dom Martina of the Netherlands Antilles, Henny Eman of Aruba, and representatives from St. Vincent and the Grenadines, came to call themselves the Group of Concerned Caribbean Leaders (the CCL). Jamaica's Seaga and St. Lucia's Compton, who had been principal backers of the U.S.'s 1983 invasion of Grenada, rejected the need for U.S. military action in Haiti outright. Instead, the Caribbean leaders would issue a communiqué after the meeting stating that, "the cancellation of the Haitian election could be attributed to as many motives as there were interest groups," ${ }^{656}$ thus treating the election-day violence as if it were the result of confrontation between equally complicit factions. A week later, as the CCL met with Namphy, Seaga "rejected the culpability of the military," stating that, "from the information his group had, it was not true to say that the army terrorized people. One of two units might have been involved...but that does not make the army as a whole culpable..." ${ }^{657}$ In fact, Seaga and his group of Caribbean leaders welcomed Namphy's announcement of new elections, claiming that he "promised adequate security for the poll..." ${ }^{658}$ During their visit to Haiti, the CCL would not meet with any of the former leading presidential candidates of the cancelled November 1987

\footnotetext{
655 "Area Leaders Offer Assistance With Elections," Bridgetown CANA [English Translation], December 2, 1987, Foreign Broadcast Information Service (FBIS) Daily Reports, Latin America, December 3, 1987.

${ }^{656}$ Ibid.

657 "Caribbean Leaders Meet Namphy, Welcome Vote," Bridgetown CANA [English Translation], December 11, 1987, Foreign Broadcast Information Service (FBIS) Daily Reports, Latin America, December 15, 1987.

${ }^{658}$ Ibid.
} 
elections, who were organizing themselves to boycott the new January 1988 elections. Seaga hoped that perhaps if the composition of the new electoral council were fair, their attitude towards the elections would change. ${ }^{659}$

Seaga and the CCL would play a central role in preventing the emergence of a unified Caribbean Community (CARICOM) response to the CNG's efforts to manipulate the upcoming elections. At the January 6 CARICOM meeting in Barbados, a fivemember Haitian delegation led by Louis Dejoie and Jean-Claude Bajeux of the democratic opposition struggled to attain a Caricom consensus condemning the $\mathrm{CNG}$ as a first step towards an international trade embargo against the regime, and as a last resort, support for an international peacekeeping force to facilitate the transition to an elected civilian government. ${ }^{660}$ Instead of a pledge from CARICOM that it would not recognize any government chosen in the fraudulent January 17 elections, the conference mostly stalled in procedural debates regarding whether the meeting would be recognized as a formal CARICOM meeting, or one of concerned Caribbean leaders. ${ }^{661}$ Dejoie, one of the Haitian delegates present at the meeting, would point to the role that the Jamaican Prime Minister played in tying up the entire process. ${ }^{62}$ According to Academician Paul La Tortue, "there was a struggle by Jamaica to 'take over'...[the] meeting and promote a U.S. point of view of the Haitian situation. He also alluded to the presence in Barbados of U.S.

\footnotetext{
${ }^{659}$ Ibid.

660 "Meeting on Haiti Begins; Haitians Attend," Kingston Domestic Service, January 6, 1988, Foreign Broadcast Information Service (FBIS) Daily Reports, Latin America, January 7, 1988.

661 "Dejoie Statement," Bridgetown CANA [English Translation], January 6, 1988, Foreign Broadcast Information Service (FBIS) Daily Reports, Latin America, January 11, 1988.

662 "Haitian Opposition View," Bridgetown CANA [English Translation], January 7, 1988, Foreign Broadcast Information Service (FBIS) Daily Reports, Latin America, January 11, 1988.
} 
deputy assistant secretary of state for Caribbean affairs, Richard Holwill whom he said had 'come out of the blue'..."663

The communiqué that would emerge from the January CARICOM meeting, while expressing concern about the upcoming Haiti elections, simply would not call for their cancelation or postponement, as demanded by the Haitian delegation. Instead, CARICOM called "on the CNG, the CEP, the Church, the candidates and others that exercise authority and influence to open a process of dialogue immediately with a view to reducing differences and hostilities, and ensuring that Haiti does not lose this opportunity to commence the process of joining the family of democratic nations and establishing the international goodwill which can be the springboard for its future development." 664 Essentially, Seaga was able to ensure that no new sanctions were levied against Haiti, that foreign military intervention was taken completely off the table, and that emphasis would be placed on ensuring that elections were carried out in Haiti, as close to free and fair as the CNG would allow. Seaga was quoted as telling diplomats that "the Caribbean leaders were originally eager to threaten sanctions against Haiti. However...the head took ascendancy over the heart based on their taking into account the stark realities and practicalities of the Haitian situation." 665

Speaking as vice president of the Socialist International (SI), former Jamaican Prime Minister, Michael Manley, would accuse the Caribbean leaders of engaging in

\footnotetext{
${ }^{663}$ Ibid.

664 "Leaders Issue Communique on Haiti Situation," Bridgetown CANA [English Translation], January 7, 1988, Foreign Broadcast Information Service (FBIS) Daily Reports, Latin America, January 11, 1988.

665 "Manley Gives Views," Bridgetown CANA [English Translation], January 13, 1988, Foreign Broadcast Information Service (FBIS) Daily Reports, Latin America, January 14, 1988.
} 
extreme cynicism as concerned the Haiti crisis, and called on the international community to unequivocally repudiation the January 17 elections. Manly particularly rejected "the suggestion implicit in the Caricom conference that bad elections [were] better than no elections," viewing such a position as "contemptuous of democracy and the Haitian people..." ${ }^{666}$ Whether or not the elections carried out be the CNG were moving the country towards democracy would not be determined by Haitians within Haiti, neither the political parties or the grassroots organizations, but by influential politicians in the socalled international community. The group of Concerned Caribbean Leaders (CCL) would answer Namphy's invitation to observe the January 17 elections. ${ }^{667}$ Similar invitations would be sent to the Organization of American States, the Organization of African Unity, the European Community, and the United Nations, ${ }^{668}$ as the majority of Haitians spoke their piece by staying home.

\section{MANIGAT, MAN OF THE MOMENT}

On January 24, 1988, Leslie Manigat would be declared president of Haiti with 50.29 percent, ${ }^{669}$ after an election in which some estimate that as little as 2 percent of the

\footnotetext{
${ }^{666}$ Ibid.

667 "Caribbean Leaders to Observe," Bridgetown CANA [English Translation], January 12, 1988, Foreign Broadcast Information Service (FBIS) Daily Reports, Latin America, January 13, 1988. "CNG Invites Observers to 17 Jan Elections," Port-au-Prince Radio Nationale [English Translation], January 12, 1988, Foreign Broadcast Information Service (FBIS) Daily Reports, Latin America, January 13, 1988.

668 Ibid.

669 "Leslie Manigat Officially Elected President," Paris AFP [English Translation], January 24, 1988, Foreign Broadcast Information Service (FBIS) Daily Reports, Latin America, January 25, 1988.
} 
population participated, ${ }^{670}$ and most deemed fraudulent. Asked about whether the low turnout would have an impact on the legitimacy of his government, Manigat asserted that "an election was valid merely if it was held and if anyone voted. If there were imperfections in the voting, he said, that was to be expected in a country where democracy was unknown," ${ }^{671}$ echoing the sentiments expressed prior to the elections by Jamaica's Seaga. Manigat would contend that while irregularities did occur, they "did not occur with a view to favoring one candidate or another in the final result...Irregularities occurred, as they occur anywhere in the world; but these irregularities did not affect the electoral process itself." ${ }^{672}$ After the elections "the State Department issued a carefully understated rejection...of the legitimacy of the elections...but said that the United States would deal with whatever government emerges..." 673

Namphy and the military hierarchy selected Leslie Manigat as the civilian they would entrust with the presidency following the January 17 elections because he could be sold to the international community, Haiti's principle institutions, and even the "responsible opposition" as respectable and competent. Manigat was described, "of the 11 candidates running in the second election," as having "by far the most impressive

\footnotetext{
670 "CED Declaration," Port-au-Prince Radio Soleil Network [English Translation], January 19, 1988, Foreign Broadcast Information Service (FBIS) Daily Reports, Latin America, January 20, 1988.

${ }^{671}$ Joseph B. Treaster, "A Paradox for Haiti's Presidency: Leslie Francois Manigat," New York Times, January 25, 1988.

672 "Manigat Interviewed on U.S. Relations," Port-au-Prince Le Petit Samedi Soir [English Translation], January 6-29, 1988, Foreign Broadcast Information Service (FBIS) Daily Reports, Latin America, February 4, 1988.

${ }^{673}$ David K. Shipler, "U.S. Calls Haiti Voting 'Clouded' but Vows to Work With Winner," New York Times, January 20, 1988.
} 
credentials. ${ }^{674}$ He hoped that though the elections were not held under ideal conditions, perhaps the United States would come to recognize that he had the right pedigree. According to Manigat, "the United States finally realized that, in the final analysis...the path taken is the proper path...especially since, basically, Washington knows who we are. ${ }^{675}$ Though he was not Marc Bazin, Manigat believed that as someone known in intellectual and political circles in the U.S. and internationally, he could not be dismissed. "Of course, we are not as well-known as the man they formerly preferred," stated Manigat, "but it is certain that we are known...through our international relations, our career...I was part of American academic institutions for a long time---either in the universities or at centers like the Woodrow Wilson center, where I was a member of the Academic Council for 8 years." ${ }^{676}$ Jamaica's Seaga, whose government was amongst the first in the region to recognize the new Haitian president ${ }^{677}$ would also tout Manigat's prestigious academic career, having taught in France at the Sorbonne, at the University of the West Indies, and recently, at the Simon Bolivar University in Venezuela, as a sign that he was worthy of international support. ${ }^{678}$ The hope was that these credentials would

\footnotetext{
${ }^{674}$ Treaster, "A Paradox for Haiti's Presidency," New York Times, January 25, 1988.

675 "Manigat Interviewed on U.S. Relations," Port-au-Prince Le Petit Samedi Soir [English Translation], January 6-29, 1988, Foreign Broadcast Information Service (FBIS) Daily Reports, Latin America, February 4, 1988.

${ }^{676}$ Ibid.

677 "Poll Results Support Decision on Haiti," Bridgetown CANA [English Translation], January 29, 1988, Foreign Broadcast Information Service (FBIS) Daily Reports, Latin America, February 10, 1988.

678 "Jamaica's Seaga Reiterates Support for Manigat," Port-au-Prince Radio Nationale [English Translation], February 2, 1988, Foreign Broadcast Information Service (FBIS) Daily Reports, Latin America, February 3, 1988.
} 
create a "favorable prejudice" towards his government, in spite of the flawed the process in which he came to power.

While the events of November 29, 1987, and the subsequent January 17, 1988 rigged elections, led Democrats in the U.S. Congress to propose an economic blockade against the new government, the Reagan administration and the other international stakeholders preferred Manigat to the possibility of an openly leftist government. ${ }^{679}$ Nevertheless, they were hesitant to give their enthusiastic support for the Manigat government. For State Department spokesman, Charles E. Redman, while the U.S. Government was "gratified" that the January 17 elections were free of the violence that characterized the previous attempt at elections, the quality of the election process did not allow it "to put Haiti in the category of countries that have completed a transition to democracy." ${ }^{680}$ Instead, they relied on regional surrogates to frame Manigat's election as a step in the right direction. Dominica's Prime Minister, Eugenia Charles, would declare her willingness to meet with Haiti's newly elected president, asserting that it would be wrong for Caricom to accept the suggestion from some of its members that ties be cut off with the new government, "saying she couldn't see how such a step could be justified when Caricom maintained relations with former President for Life Jean Claude 'Baby Doc' Duvalier." ${ }^{681}$ For Charles, "at least Mr. Manigat had a portion of the people of Haiti say they want him as their leader." 682

\footnotetext{
679 "PUCH Head on Domestic Situation, Party's Role," Budapest NEPSZABADSAG [English Translation], April 22, 1988, Foreign Broadcast Information Service (FBIS) Daily Reports, Latin America, Aprils 26, 1988.

${ }^{680}$ David K. Shipler, "U.S. Calls Haiti Voting 'Clouded' but Vows to Work With Winner," New York Times, January 20, 1988.

681 "Charles Willing to Meet With Haiti's Manigat," Bridgetown CANA [English Translation], April 16,
} 
According to Secretary of State George P. Shultz, "while the democratic transition that the United States had hoped for in Haiti had not succeeded, it had 'not failed either."'183 U.S. Government officials would establish a number of criteria to evaluate whether or not the Manigat government was indeed moving in the right direction. These included whether his government was able to operate as "a truly independent and responsible organ, rather than just a front for the military"; whether it was clear that his intent was to use the flawed elections of January 17 as "a way station to a more democratic form of government"; whether he would allow the opposition to operate freely; and the extent to which he tried to "bring a broad spectrum of political representation into his government." ${ }^{\text {"64 }}$ Even prior to his selection in the January 17 elections, the State Department viewed Leslie Manigat's candidacy in positive terms, particularly noting his pledge to form a "national unity cabinet that would include a broad political spectrum." 685

As Manigat took the U.S.'s "wait and see" attitude as a sign of tacit support, he subsequently shifted his focus towards actively recruiting members of "responsible opposition" to support his government. Though Manigat had once worked in François Duvalier's Ministry of Foreign Affairs, he came from amongst the "responsible opposition." After serving in the Duvalier government for a few years, Manigat quickly

1988, Foreign Broadcast Information Service (FBIS) Daily Reports, Latin America, April 20, 1988.

${ }^{682}$ Ibid.

${ }^{683}$ Joseph B. Treaster, "Haitians Warily Enter an Uncertain New Era," New York Times, Feb 7, 1988.

${ }^{684}$ Shipler, "U.S. Calls Haiti Voting 'Clouded'," New York Times, January 20, 1988.

${ }^{685}$ Ibid. 
fell from grace, accused of having organized a student strike, and was imprisoned for two months, after which he went into exile in 1963, becoming one of the more outspoken critics of the regime for 23 years. ${ }^{686}$ Alongside his academic pursuits in exile, Manigat would also come to establish the Assembly of Progressive National Democrats (Rassemblement des Démocrates Nationaux Progressistes, or RDNP), with links to the emerging Christian Democratic parties throughout the region. Manigat was thus very much a member of Haiti's political class. Manigat's first initiative upon coming to power was to "once again offer a hand to the opposition," ${ }^{687}$ declaring that his government would be based on dialogue and consensus, drawing from his experience observing Venezuelan democracy firsthand ${ }^{688}$ Ironically, Manigat would call on the opposition to "respect the rules of the democratic game" and take on their proper role "not to overthrow governments but rather to criticize the government, with a view to winning the next elections and prodding the government in power to accomplish things." ${ }^{689}$

Many would begin calling on Haiti's institutions, the media, the Church, and particularly, the opposition parties, to give Manigat a chance. They argued that Manigat was a capable and competent democrat who could lead the country in the right direction if the opposition would act responsibly rather than play the role of obstructionists. Former CNG Minister of Information, Gerard Noel, would send an open letter to the Episcopal

\footnotetext{
${ }^{686}$ Joseph B. Treaster, "A Paradox for Haiti's Presidency: Leslie Francois Manigat," New York Times, January 25, 1988.

687 "Manigat on Duvalierism, Reform, Military Role," Port-au-Prince Radio Metropole [English Translation], February 3, 1988, Foreign Broadcast Information Service (FBIS) Daily Reports, Latin America, February 5, 1988.

${ }^{688}$ Ibid.

${ }^{689}$ Ibid.
} 
Conference of Haiti, the Catholic Church hiearchy in Haiti, asking it "to designate Msgr Joseph Lafontant, the auxiliary bishop of Port-au-Prince, as a kind of mediator, so he can see if he can get the opposition and the new government together through negotiations and dialogue." ${ }^{690}$ The Anglican Orthodox Church in Haiti would publish a statement also supporting such reconciliation between Manigat and the opposition. The Anglican Church believed that, never in its history did Haiti have such an opportunity or such potential for democracy. It argued that at this moment in time, Haiti had, "on the one hand, a superb democratic accord, made up of structured political parties, with, at their heads, men of exceptional intellectual, moral, and patriotic qualities," in the CED and the four former presidential candidates, "and on the other hand, a political party and its leader possessing these same qualities which have come to power," in Manigat and the RDNP. ${ }^{691}$ The Anglican Church hoped that the CED would organize itself into a "constructive opposition" for the new government, while giving it time to prove itself. ${ }^{692}$ Even politicians who boycotted the January 17 elections because they violated the Constitution of 1987 began to call for dialogue and reconciliation. This was the position of Thomas Desulme, leader of the National Labor Party (PNT), who believed that the country found itself having to choose between "a sterile hardening of line...with its foreseeable--and unforeseeable--consequences for national sovereignty and its destructive

\footnotetext{
690 "Letter Sent to CEH Asking for Mediation," Port-au-Prince Radio Nationale [English Translation], January 28, 1988, Foreign Broadcast Information Service (FBIS) Daily Reports, Latin America, January 29, 1988.

691 "Anglican Church Calls for Reconciliation," Port-au-Prince Radio Metropole [English Translation], February 2, 1988, Foreign Broadcast Information Service (FBIS) Daily Reports, Latin America, February 10, 1988.

${ }^{692}$ Ibid.
} 
effects on our already so precarious economic and social structures; and a realistic and pragmatic attitude..."693 Desulme believed that the stated intentions of Manigat and his political party, the RDNP, should not be minimized, considering their declared support for civil liberties and policies to uplift the peasant and working classes. He called for a truce, to allow the political parties to better organize themselves, so that they can play a greater role in facilitating civic education throughout Haiti. ${ }^{694}$ Eventually, the members of the CED began to oblige.

While they maintained that the January 17 elections were "an unconstitutional and undemocratic farce" and did "not for the time being envision any collaboration with the future government," the four members of the Committee for Democratic Agreement [CED] pledged to "serve as constructive and loyal opposition groups to the new president as long as the new president exhibited a will to establish a true democracy in Haiti." ${ }^{695}$ Though it was sad for Louis Dejoie to see Manigat come to power in such an illegal fashion, he felt the fact that the Army was no longer in power was a positive. More importantly, Dejoie felt that this was the first time in history that Haiti had such a "highly-intelligent" and "capable" president, and thus declared that his party would not engage in subversive opposition. ${ }^{696}$ Bazin similarly rejected being part of "a totally negative opposition, which constantly criticizes everything and never approves of

\footnotetext{
693 "Desulme Calls for Suspension of Hostilities," Port-au-Prince Radio Metropole [English Translation], January 29, 1988, Foreign Broadcast Information Service (FBIS) Daily Reports, Latin America, February $1,1988$.

694 Ibid.

695 "Opposition Comments," Port-au-Prince Radio Metropole [English Translation], February 9, 1988, Foreign Broadcast Information Service (FBIS) Daily Reports, Latin America, February 11, 1988.

${ }^{696}$ Ibid.
} 
anything," instead calling on the opposition to be "sober" and "responsible." ${ }^{697}$ Serge Gilles of the National Concerted Action Front (FNC), the banner under which Gerard Gourgue ran for president, also called for his party to "structure and organize itself so it can be a modern and serious opposition group in Haiti." ${ }^{698}$

After securing nominal support from the "responsible opposition," Manigat began working on winning over the country's private sector. On January 27, Manigat would meet with 30 of the country's most prominent merchants, businessmen, and industrialists at his home ${ }^{699}$ in order to "get acquainted" and "establish trust" between the government and the private sector. ${ }^{700}$ According to Manigat, the private sector would be essential to a process of "integrated economic development for the population," which he deemed essential to "social integration." ${ }^{701}$ While in his inauguration speech, Manigat assured the private sector that "the freedom of enterprise [was] inseparable from his concept of democracy," ${ }^{702}$ he stressed to the urban and rural poor that "because of the seriousness of the economic crisis...the arrival of the new administration 'does not mean abundance in

\footnotetext{
697 "Bazin: Wants Deeds Not Words," Port-au-Prince Radio Metropole [English Translation], February 9, 1988, Foreign Broadcast Information Service (FBIS) Daily Reports, Latin America, February 11, 1988.

698 "Opposition Comments," Port-au-Prince Radio Metropole [English Translation], February 9, 1988, Foreign Broadcast Information Service (FBIS) Daily Reports, Latin America, February 11, 1988.

699 "Manigat Talks With Businessmen on Economy," Port-au-Prince Radio Nationale [English Translation], January 28, 1988, Foreign Broadcast Information Service (FBIS) Daily Reports, Latin America, January 29, 1988.

700 "Manigat on Private Sector," Port-au-Prince Radio Metropole [English Translation], January 28, 1988, Foreign Broadcast Information Service (FBIS) Daily Reports, Latin America, January 29, 1988.

701 "Manigat Talks With Businessmen on Economy," Port-au-Prince Radio Nationale [English Translation], January 28, 1988, Foreign Broadcast Information Service (FBIS) Daily Reports, Latin America, January 29, 1988.

702 "New President Calls for National Reconciliation," Paris AFP [English Translation], February 7, 1988, Foreign Broadcast Information Service (FBIS) Daily Reports, Latin America, February 8, 1988.
} 
the near future but, on the contrary, a progressive austerity to work for a better tomorrow."'703 National reconciliation under Manigat was thus to be built around cooperation between a nominally popular "responsible opposition" and civilian government that came to power in elections rigged by a Duvalierist military, which promises to work in the service of the private sector, while the poor and working class are instructed to wait for these policies to bear fruit.

\section{APPEAL TO THE PEOPLE}

While initially Manigat accepted Namphy and the military hierarchy's "minimal consensus," as he received positive signs of support from the international community, Haiti's private sector, and segments of "the responsible opposition," he began advocating more aggressively for a reformist agenda. To communicate this agenda, Manigat would inaugurate a series of radio and television broadcasts called Koze An Ba Tonel Avek Pep $L a$, or "A Friendly Chat with the Haitian People," where twice a month, he would speak directly to the Haitian people about the progress being made by his government. ${ }^{704}$ According to Manigat, "the country had been going in the wrong direction for the past 30 years. For 30 years, problems were left to accumulate, and bad habits took root in the country." 705 As a result of this legacy, "abnormality" became engrained in the Haitian

\footnotetext{
${ }^{703}$ Ibid.

704 "Manigat to Address People Via Radio, TV Casts," Port-au-Prince Radio Nationale [English Translation], February 18, 1988, Foreign Broadcast Information Service (FBIS) Daily Reports, February 19, 1988.

705 "Manigat: Government Needs Time, Joint Efforts," Port-au-Prince Nationale [English Translation], March 19, 1988, Foreign Broadcast Information Service (FBIS) Daily Reports, Latin America, March 23, 1988.
} 
government as the norm. So, despite believing that it was necessary to maintain dialogue with the Duvalierists, he also found it "normal that, when affecting a revolution, a change, at the end of a dictatorship, in making the transition to democracy, you make a profound critique of the dictatorship." ${ }^{706}$ Manigat thus felt that his mandate was to reform a government that "had been set up to benefit a particular category of people" and have it "serve the entire Haitian people, particularly, those with the greatest need." ${ }^{707}$

For Manigat, this meant shifting the emphasis of gaining access to state power away from self-enrichment towards doing work for the public, and thus transforming government ministries into "instruments for the policy of social justice and modernization," and most importantly, democracy. ${ }^{708}$ One of the first steps Manigat took to emphasize he did not seek government power in order to enrich himself or those around him, was to restructure the salary scale, to "take the salaries being paid out by the government and try to make them more socially just."${ }^{709}$ While Manigat did not deny that there were those who deserved high salaries, he argued that they were living "in Haiti--not in the United States or in France," and that Haiti was a poor country, so those working for the public needed "to live within [their] means." ${ }^{710}$ Moreover, his government would not lower the salaries of anyone making below $\$ 1,000$ a month,

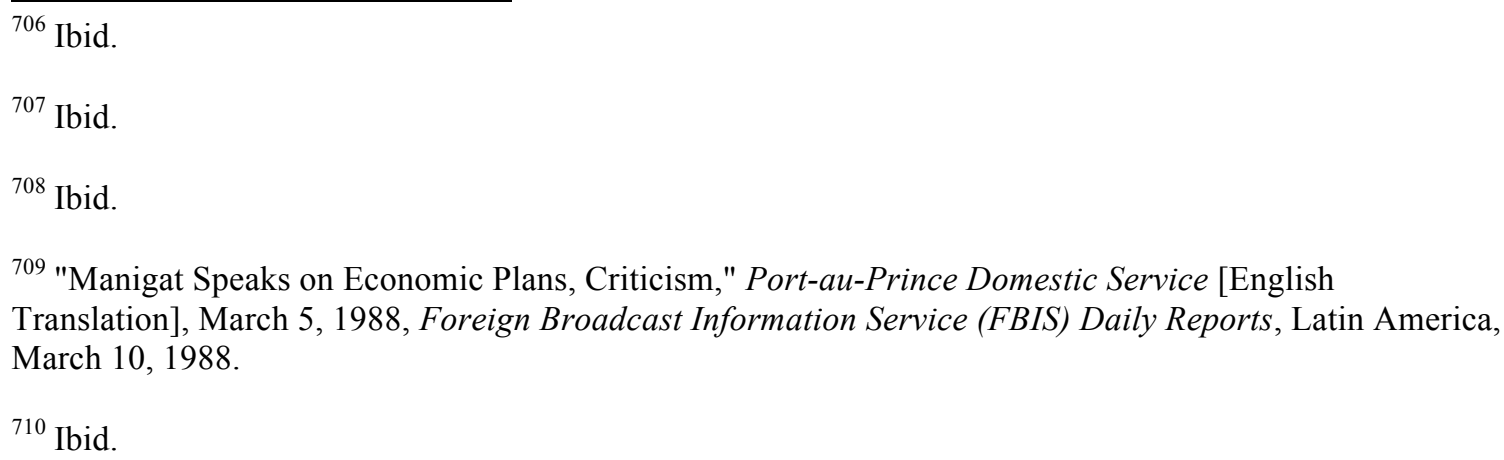


promising to raise these salaries as the country's economy began growing again, thus reducing "the gap between big and small salaries." 711

Manigat also pointed to the need to address corruption and graft in government. He announced that his government expected stealing from the state to stop, framing his anti-corruption stance in social justice terms. According to Manigat, money stolen from the state was "the people's money...paid in taxes...from the people's production," "money that could have been used to serve the people...to build the roads, schools, dispensaries, and hospitals that we need." ${ }^{712}$ Manigat made increasingly more desperate overtures to members of the "responsible opposition" as he faced resistance to his reforms. He called on them to take courage, to take a stand, to take initiative, against this legacy of corruption in government. "If they leave the field to dishonest people and scoundrels; if they allow people in the habit of stealing to continue in the forefront, to surround the government, to surround the ministries, they will have only themselves to blame," Manigat declared. "Since they know for sure the government now is competent, honest, and serious, people who are competent, honest, and serious must support the government. They must step up to the foreground." ${ }^{713}$

What would escalate the confrontation between the partisans of the old regime and the Manigat government further was its efforts to stop contraband in order to increase customs duties. He argued that when his administration came to power, it found the government in very poor financial shape, primarily because "the money the government

\footnotetext{
${ }^{711}$ Ibid.

${ }^{712}$ Ibid.

${ }^{713}$ Ibid.
} 
expected to receive from two fundamental sectors, customs and income taxes..." was not being adequately collected. ${ }^{714}$ Therefore, the Manigat government established an antismuggling task force and inspection brigades to monitor activity at the International Airport and provincial ports in order to reduce the occurrence of false shipping manifestos, phony invoices, bribery, and other measures used to avoid paying proper customs dues. Again, these measures would be justified within a framework of social justice. What those who sought to avoid paying customs dues and taxes needed to understand, Manigat argued, was that, "when you pay taxes, you are helping the government open schools, build hospitals, dig irrigation canals, and do what needs to be done in the country so that we can truly embark upon the path of development." ${ }^{715}$

While Manigat pursued his reformist agenda, he failed to appropriately appreciate the reality that he was placed in power by the military in order to preserve the status quo, so as not to threaten the fundamental interests of Duvalierists and those who benefit from their access to state power. From the very start, Reverend Allan Kirton of the Caribbean Conference of Churches (CCC) warned that it would be nearly impossible for Manigat to deliver on his campaign promises to the population. For one, the presidency had been fundamentally weakened in the new Constitution of 1987, with power shifted to the parliament, which was now dominated by Duvalierists who held 80 percent of the seats. ${ }^{716}$ The power of the Duvalierists was also preserved throughout the countryside, as

\footnotetext{
${ }^{714}$ Ibid.

715 "Measures to Fight Contraband Smuggling Praised," Port-au-Prince Radio Nationale [English Translation], April 1, 1988, Foreign Broadcast Information Service (FBIS) Daily Reports, Latin America, April 25, 1988.

716 "CCC Leader on Haiti's Political Situation," Bridgetown CANA [English Translation], February 24, 1988, Foreign Broadcast Information Service (FBIS) Daily Reports, Latin America, February 25, 1988.
} 
results of the January 31st CASEC (Administrative Councils for the Communal Sections) elections were never released. ${ }^{717}$ According to the Komite Tet Ansanm pou Hone, Respe, Konstitisyon an (the Cooperative Action Committee for the Respect of the Constitution), "without the Casecs, there are no municipal assemblies, no departmental assemblies, no interdepartmental council, and no Permanent Electoral Council, and thus, no decentralization, no participation, and no democracy..." ${ }^{718}$ So, though Manigat was president, most of Haiti's representative institutions were either filled with Duvalierists, or were not allowed to operate.

As the Manigat government called for reform, increasingly the powerful utilized Duvalier-era tactics to reassert their control over the poor and working class. In April, as a labor dispute escalated between workers and management, soldiers from Fort Dimanche would be sent to the Omnicron factory to reestablish order. ${ }^{719}$ Haiti's largest labor federations, CATH, FOS, and CNEH, would write to the government's Social Affairs Minister to declare that "the presence of soldiers armed to the teeth" in Haiti's factories was "designed to intimidate workers and arbitrarily repress their legitimate demands, as well as destroy the union movement." ${ }^{720}$ They also rejected the use of the Duvalierist

\footnotetext{
717 "Communal Sections on Official Election Results," Port-au-Prince Radio Nationale [English Translation], March 8, 1988, Foreign Broadcast Information Service (FBIS) Daily Reports, Latin America, March 9, 1988.

718 "Action Committee Calls for New Elections," Port-au-Prince Radio Metropole [English Translation], April 25, 1988, Foreign Broadcast Information Service (FBIS) Daily Reports, Latin America, April 27, 1988.

719 "Mill Workers Return; More Labor Conflicts Noted," Port-au-Prince Radio Soleil Network [English Translation], April 14, 1988, Foreign Broadcast Information Service (FBIS) Daily Reports, April 15, 1988.

720 "Unions Address Minister on Rights Violations," Port-au-Prince Radio Soleil Network [English Translation], April 26, 1988, Foreign Broadcast Information Service (FBIS) Daily Reports, Latin America, April 28, 1988.
} 
labor code to declare strikes at the Minoterie d'Haiti and Ciment d'Haiti illegal, emphasizing that the Constitution of 1987 recognized the people's right to strike. ${ }^{721}$

In the provinces, the return to Duvalierism was particularly pronounced. According to PUCH's Rene Theodore, "a series of little chiefs" were reappearing across the country, in places like "Les Cayes, where the prefect has said people cannot form associations without authorization from him; or in Thiotte, where a communal magistrate has said people may not report news over the radio regarding his area without authorization. ${ }^{722}$ Increasingly, the specter of another Jean-Rabel massacre loomed everpresent in the northwest as peasant organizations, determined to assert their rights to form peasant associations, were labeled communists and threatened by the local section chief and regional commander. ${ }^{723}$

More problematic still, was the shadow the military continued to cast over Manigat's government. Henri Namphy, prior to the cancelled November 1987 elections, had "named himself head of the armed forces for three years more, a move that worried some in Haiti because the Constitution gives the President the power to appoint the Commander in Chief." ${ }^{724}$ Also, in an attempt to maintain the support of the military high command, Manigat appointed Major General Williams Regala the Minister of Interior

\footnotetext{
${ }^{721}$ Ibid.

722 "PUCH's Theodore Says Celestin 'Incompetent'," Port-au-Prince Radio Metropole [English Translation], March 17, 1988, Foreign Broadcast Information Service (FBIS) Daily Reports, Latin America, March 18, 1988.

723 "Situation Among Peasants in Northwest 'Uneasy,"' Port-au-Prince Radio Metropole [English Translation], April 19, 1988, Foreign Broadcast Information Service (FBIS) Daily Reports, April 21, 1988.

724 "Joseph B. Treaster, "Bestower of Silence and Despair: Henri Namphy," New York Times, June 21, 1988.
} 
and National Defense. ${ }^{725}$ And, even more troubling, Manigat faced the threat of Colonel Jean-Claude Paul, unspoken leader of the Tonton Macoutes and commander of the notorious Dessalines Battalion, ${ }^{726}$ whose barracks adjoined the Presidential Palace and stored all the ammunition for the Haitian army. Paul was rumored to be responsible for orchestrating the November 1987 election-day massacre, ${ }^{727}$ and accused by the U.S. of drug trafficking. ${ }^{728}$ According to Kirton of the CCC, while Manigat inherited an empty treasury, the Haitian Army was flush with cash as a result of its involvement in drug trafficking. ${ }^{729}$ It was also believed that the military was heavily involved in the growing contraband trade. ${ }^{730}$

As insecurity increased in Port-au-Prince and the provinces, it became clear that the Manigat government was trapped in a particularly precarious situation. On the one hand, slogans increasingly hostile to the Manigat government and in support of the Army began to appear "written on paper and affixed to walls" across the country. ${ }^{731}$ On the

\footnotetext{
725 "Major General Regala Resigns From Armed Forces," Port-au-Prince Radio Metropole [English Translation], February 10, 1988, Foreign Broadcast Information Service (FBIS) Daily Reports, February $11,1988$.

726 "CCC Leader on Haiti's Political Situation," Bridgetown CANA [English Translation], February 24, 1988, Foreign Broadcast Information Service (FBIS) Daily Reports, Latin America, February 25, 1988.

727 "Haitian Officer Charged by U.S. is Reported Dead," New York Times, November 7, 1988.

728 "Government Refuses Comment on U.S. Indictment," Port-au-Prince Radio Soleil Network [English Translation], March 11, 1988, Foreign Broadcast Information Service (FBIS) Daily Reports, Latin America, March 14, 1988.

729 "CCC Leader on Haiti's Political Situation," Bridgetown CANA, February 24, 1988.

730 "Manigat Government Said Facing 'Big Problem,'" Port-au-Prince Radio Soleil Network [English Translation], May 23, 1988, Foreign Broadcast Information Service (FBIS) Daily Reports, Latin America, May 24, 1988.

731 "Anti-Manigat Slogans, Abuse by Soldier Reported," Port-au-Prince Radio Metropole [English Translation], April 11, 1988, Foreign Broadcast Information Service (FBIS) Daily Reports, Latin America, April 13, 1988.
} 
other hand, the government was entirely dependent on the military to contain the escalating criminal activity and destabilization campaign being carried out by armed civilians likely connected with macoute forces resurgent in the aftermath of the November 29 election-day massacre. It was not clear whether the growing number of night robberies, shootings, and murders were simply the result of worsening economic conditions, or politically motivated, particularly as these groups were able to avoid apprehension by the police. ${ }^{732}$ Complicating the nature of these events even further, were reports that often these acts were being carried out by armed "men wearing military uniforms." 733

While he acknowledged his campaign promise of national reconciliation, Manigat would also make note on national television, that those who benefited from this policy "should not forget that a certain regime was in fact overthrown on 7 February 1986---and for very specific reasons." ${ }^{734}$ According to Manigat, "they were in fact spurned by the Haitian people for having killed and stolen and for having gotten this country into the condition it is in today." ${ }^{735}$ Having been rejected by the people, Manigat declared that it

\footnotetext{
732 "'Turbulent' Situation Reported in Delmas Area," Port-au-Prince Radio Soleil Network [English Translation], April 14, 1988, Foreign Broadcast Information Service (FBIS) Daily Reports, Latin America, April 15, 1988. "Gunfire, Robberies Resume at Night in the Capital," Port-au-Prince Radio Metropole [English Translation], April 19, 1988, Foreign Broadcast Information Service (FBIS) Daily Reports, Latin America, April 21, 1988.

733 "Holdups by Men in Military Uniforms Reported," Port-au-Prince Radio Haiti-Inter [English Translation], April 18, 1988, Foreign Broadcast Information Service (FBIS) Daily Reports, Latin America, April 19, 1988.

734 "Radio Soleil on 'Wave of Insecurity' in Capital," Port-au-Prince Radio Soleil Network [English Translation], May 3, 1988, Foreign Broadcast Information Service (FBIS) Daily Reports, Latin America, May 5, 1988.

735 "Manigat on National Reconciliation Policy," Port-au-Prince Le Progressiste Haitien [English Translation], April 28, 1988, Foreign Broadcast Information Service (FBIS) Daily Reports, Latin America,
} 
would be unreasonable to reestablish this kind of regime in Haiti again, particularly through the violence and criminality being carried out on the streets of Port-au-Prince. For Manigat, the country had turned the page, and was now writing "a new history on a new and virgin page." ${ }^{736}$ Only twenty-four hours after Manigat ushered that warning, "gunmen in a moving car...opened fire on pedestrians in downtown Port-au-Prince," killing one and injuring several others. ${ }^{737}$

To counter the growing threat against his government from the reactionary groups he aligned himself with to gain the presidency, Manigat would increasingly attempt to build support amongst the poor and working class, including the common soldiers. The "People's Houses" would be one such initiative targeted to the poor. According to Manigat, through a bilateral aid program, Venezuelan soldiers and engineers would work closely with the Haitian Army to produce low-cost homes, not only for poor civilians, but also for members of the Haitian military. This would "illustrate the Army's new role and, at the same time, the new concept of society, to show that we are not starting off on the basis of division between the civilians and the military." ${ }^{738}$ Manigat would also highlight a French cooperation program where 40 to 50 villages would be chosen for the

\footnotetext{
May 2, 1988.

${ }^{736}$ Ibid.

737 "Violence Begins After Manigat Warns Duvalierists," Bonaire Trans World Radio [English Translation], April 29, 1988, Foreign Broadcast Information Service (FBIS) Daily Reports, Latin America, May 2, 1988.

738 "Manigat Speaks on Economic Plans, Criticism," Port-au-Prince Domestic Service [English Translation], March 5, 1988, Foreign Broadcast Information Service (FBIS) Daily Reports, Latin America, March 10, 1988.
} 
installation of solar-powered lights and television sets. ${ }^{739}$ Despite successes cobbling together "\$4 million worth of aid from Taiwan, 5 million Deutsche marks from the FRG, and \$1 million from France," Manigat could not put together a significant enough development policy without the $\$ 60$ million in aid being withheld by the U.S. as a result of continued Congressional rejection of the September 17 elections, along with "\$20 million from the World Bank and $\$ 17$ million from the IMF still pending. ${ }^{740}$ Without enough international aid to build a coalition amongst Haiti's poor and working class, Manigat would offer Haiti's peasant majority the one thing that they always coveted, access to government land.

Manigat's offer of land reform was particularly salient at a moment when the peasantry was mobilizing politically to resist the rural power structures that historically exploited them. Increasingly, peasants across the country rejected the escalating costs of leasing state-owned land. According to the peasants in the southeast, just prior to fall of Jean-Claude in February 1986, the cost to rent a carreau [1.29 hectares] of public land was about 47 gourdes. In the two years since, they were expected to pay 350 to 600 gourdes for the same carreau of land. ${ }^{741}$ Peasant groups levied similar complaints throughout the provinces. In the Central Plateau, "everyone you meet talks to you about the cost of leasing land from the government," but also the fact that there are no schools,

\footnotetext{
739 "Manigat: Government Needs Time, Joint Efforts," Port-au-Prince Nationale [English Translation], March 19, 1988, Foreign Broadcast Information Service (FBIS) Daily Reports, Latin America, March 23, 1988.

740 "Manigat Government Said Facing 'Big Problem,"' Port-au-Prince Radio Soleil Network [English Translation], May 23, 1988, Foreign Broadcast Information Service (FBIS) Daily Reports, Latin America, May 24, 1988.

741 "Further on Labor, Land Problems Facing Peasants," Port-au-Prince Radio Antilles-Internationales [English Translation], April 4, 1988, Foreign Broadcast Information Service (FBIS) Daily Reports, Latin America, April 7, 1988.
} 
clean drinking water, or dispensaries in their rural communities. ${ }^{742}$ In La Gonave, "the peasants feel it is their duty to pay their leases...so there will be money in the state coffers for development. However...nothing is ever done for their villages with the money collected from them." ${ }^{173}$ In Les Cayes, the peasants cried that while "they pay a lot of money," to grow on government land, "they have no water with which to irrigate, and if it doesn't rain, they lose their harvests." ${ }^{744}$ Worse still, according to the peasants, was that the powerful and wealthy, who could afford to pay the high costs of the lease, were often given advantages and paid less. ${ }^{745}$ Rather than address the concerns of the small peasants, powerful local officials threatened to seize and sell the land of families who had been leasing from the government "from generation to generation, for 30, 40, and even 50 years," should they fail to pay their lease for even a week. ${ }^{746}$ As they were threatened with eviction, peasants across the country declared that they were refusing to pay their rents and taxes until they were lowered to more reasonable rates, the government provided services to their communities, and they were allowed to freely choose their local government representatives. Peasants in Hinche declared that anyone who tried "to evict

\footnotetext{
742 "Peasants Protest Rents; Refuse to Pay Taxes," Port-au-Prince Radio Soleil Network [English Translation], April 5, 1988, Foreign Broadcast Information Service (FBIS) Daily Reports, Latin America, April 6, 1988.

743 "La Gonave Complaints Cited," Port-au-Prince Radio Nationale [English Translation], April 5, 1988, Foreign Broadcast Information Service (FBIS) Daily Reports, Latin America, April 7, 1988.

744 "Commando Murders Man; Cost of Land Protested," Port-au-Prince Radio Soleil Network [English Translation], April 22, 1988, Foreign Broadcast Information Service (FBIS) Daily Reports, Latin America, April 25, 1988.

745 "Cost of Land Leasing in Northwest Protested," Port-au-Prince Radio Metropole [English Translation], April 20, 1988, Foreign Broadcast Information Service (FBIS) Daily Reports, Latin America, April 22, 1988.

746 "Further on Labor, Land Problems Facing Peasants," Port-au-Prince Radio Antilles-Internationales, April 4, 1988.
} 
them without giving them a better place to move to [would] face trouble" ${ }^{747}$ Similarly in Maissade, they hoped no one would use force against the peasant population of the areas "because if anyone were to employ violence, everyone would rise up and counter such violence." 748

On May 1st, Labor Day, Manigat would announce his plan for agrarian reform based on "jointly-owned, cooperative rural properties." His government would grant nontransferable and indivisible portions of state lands to groups of peasants to work and share the profits from in common. These rural cooperatives would be given "priority technical support from the state and agricultural credit on privileged conditions," as well as support from various government ministries, with the view of modernizing Haitian agriculture. According to Manigat, this plan was closely compatible with demands for land reform found in the Constitution of $1987 .^{749}$

Through this announced land reform, Manigat hoped that he could generate enough support for his government that the popular organizations would send the masses out in the streets to serve as a counterforce against the threat of a coup d'état by the military. Nevertheless, the month of May would be characterized by an escalation in the level of insecurity, with over 20 people shot and killed by roving groups of armed men.

"Mr. Manigat said the climate of insecurity was created by social violence resulting from

\footnotetext{
747 "Hinche Peasants to Defy Any Eviction Attempt," Port-au-Prince Radio Soleil Network [English Translation], April 8, 1988, Foreign Broadcast Information Service (FBIS) Daily Reports, Latin America, April 11, 1988.

748 "Maissade Takes Tax Stand," Port-au-Prince Radio Soleil Network [English Translation], April 6, 1988, Foreign Broadcast Information Service (FBIS) Daily Reports, Latin America, April 7, 1988.

749 "Manigat Introduces Rural Property Plan," Port-au-Prince Radio Nationale [English Translation], May 1, 1988, Foreign Broadcast Information Service (FBIS) Daily Reports, Latin America, May 3, 1988.
} 
an improper distribution of wealth, as well as by political violence, which he says is due to nostalgia for power, meaning people thirsting for power, people who would like to hold onto power but who lost it." ${ }^{750}$ Again, out of a sense of growing desperation, the Manigat government would appeal to the popular organizations by announcing a new security plan, which called for "the controlled reorganization of neighborhood committees and vigilance brigades...not with a free hand like before, but rather in compliance with an overall plan drawn up jointly by the minister of justice and the police..." ${ }^{751}$ The public would also be called upon to cooperate with his government in identifying people and cars deemed suspicious. ${ }^{752}$

Vigilance committees and brigades throughout the country, such as the National Haitian People's Cooperative Action Group, Movement of Democratic Organizations, Committee for Vigilance Against Evildoers, and the Veteran Haitian Servicemen's Association, instantly denounced Manigat's security plan. They asked the president whether he wanted to create vigilance brigades or develop new macoute units. ${ }^{753}$ Similar sentiments were echoed by Sylvio Claude's PDCH, who rejected the notion that the current insecurity gave the Manigat government justification to "create an institution paralleling the constitutional forces," measures it deemed reminiscent of how François Duvalier's tonton macoutes and Jean-Claude's Service d'Information (SD) came into

\footnotetext{
750 "Manigat Government Said Facing 'Big Problem,'" Port-au-Prince Radio Soleil Network, May 23, 1988.

751 "New Government Security Plan Outlined," Port-au-Prince Radio Metropole [English Translation], May 6, 1988, Foreign Broadcast Information Service (FBIS) Daily Reports, Latin America, May 9, 1988. 
existence. ${ }^{754}$ The Federation of Neighborhood Committees and Associations (Fedka) viewed Manigat's call to integrate the vigilance brigades into the government "an attempt to make the people think that the government and the Army are not the ones responsible for the current insecurity in Haiti." ${ }^{755}$ Particularly damning were statements issued by the Women's Committee for the Liberation of Haiti, who asked Manigat, where was he when the military was "brutally dismantling the vigilance brigades" in order to "prevent the people's election from being held?"1756 These vigilance committees would call on others like themselves to resist being co-opted at all costs. "Do not forget the circumstances under which you came into being," they declared. "We will not work with any government to which we have not accorded legitimacy."157

\section{THE CHARADE ENDS}

Having failed to recruit the people's organizations to defend his government from the threat posed by the military and the roving bands of armed macoutes, Manigat would attempt to manipulate an impending conflict between the two most prominent figures within the Haitian Army, Lieutenant General Henri Namphy, Commander-in-Chief of the Army, and Colonel Jean-Claude, head of the Dessalines Battalion, to oust the former

\footnotetext{
754 "PDCH Expresses Concern," Port-au-Prince Radio Soleil Network [English Translation], May 12, 1988, Foreign Broadcast Information Service (FBIS) Daily Reports, Latin America, May 16, 1988.

755 "'Death Squad' Scored," Port-au-Prince Radio Soleil Network [English Translation], May 12, 1988, Foreign Broadcast Information Service (FBIS) Daily Reports, Latin America, May 16, 1988.

756 "Womens' Group Reacts," Port-au-Prince Radio Soleil Network [English Translation], May 12, 1988, Foreign Broadcast Information Service (FBIS) Daily Reports, Latin America, May 16, 1988.

757 "Committee Restructuring Protested," Port-au-Prince Radio Soleil Network, May 12, 1988.
} 
head of the CNG. Manigat would turn to the Constitution of 1987, which was violated to assure his presidency, in order to claim civilian control over Haiti's armed forces.

On June 14, 1988, General Namphy would summon Colonel Paul and nine other officers separately to give them new assignments. Paul in particular was to be reassigned to the Army General Headquarters, and named assistant head of the General Staff. "Haitians in close contact with the armed forces...said Colonel Paul returned to his office behind the palace and told Mr. Manigat by telephone that he wished to remain as commander of the Dessalines Battalion," after which, "Manigat reportedly pledged his support for Colonel Paul," 758 who subsequently barricaded himself inside the Dessalines barracks, leading to a crisis within Haiti's armed forces. This was the first sign of major fractures within the military since it emerged as the dominant political institution following Jean-Claude's departure in February 1986. Paul's soldiers would declare that they would "not have Col. Paul leave the Dessalines Barracks" but would "either live or die with Col. Paul," calling on Namphy to just keep his communiqué. ${ }^{759}$ Manigat would subsequently issue his own, rescinding the military transfers ordered by Namphy, stating that "all decisions in connection with the reshuffle were made without the prior knowledge of the president of Haiti, who is constitutionally the head of the Haitian Armed Forces, even though he does not command them personally." ${ }^{760}$ Its final words called on Namphy to stay the transfers in order to avoid a crisis.

\footnotetext{
${ }^{758}$ Joseph B. Treaster, "Haiti's President Rejects Military Order," New York Times, June 16, 1988.

759 "Dessalines Soldiers Interviewed," Port-au-Prince Radio Soleil Network [English Translation], June 15, 1988, Foreign Broadcast Information Service (FBIS) Daily Reports, Latin America, June 16, 1988.

760 "Manigat Issues Communique," Port-au-Prince Radio Metropole [English Translation], June 15, 1988, Foreign Broadcast Information Service (FBIS) Daily Reports, Latin America, June 16, 1988.
} 
While initially rumored that Namphy was planning to use the Leopards Corps and other troops to force Paul out of the Dessalines barracks, ${ }^{761}$ the Haitian Armed Forces High Command would issue a statement rescinding the transfer orders, "reaffirm[ing] the institution's unreserved loyalty to the nation's government within the framework of the dispositions of the Constitution and the law... ${ }^{762}$ Manigat would frame the crisis as "a democratic learning experience," whereby the "civilian government and the military institution have together and in concert given the nation a lesson in patriotism and democracy," which made him "optimistic about the future of democracy in Haiti..."763

For many observers of the standoff, Manigat's actions were a significant departure from the cautious obsequiousness he had displayed towards the military since taking part in the rigged January elections. Some speculated that perhaps Manigat sought to make a deal with Colonel Jean-Claude Paul, not to extradite him to the United States where he was being indicted for involvement in drug trafficking, in return for his support against Namphy and other officers who were particularly antagonistic towards his government. Utilizing the momentum from what turns out to be a pyrrhic victory, Manigat would retire Namphy and his supporters from the Army, declaring that it was the president's duty as constitutional head of the Haitian Armed Forces to "reestablish the hierarchy so as to open the way to democratization and modernization and place the Armed Forces at

\footnotetext{
${ }^{761}$ Joseph B. Treaster, "Haiti's President Rejects Military Order," New York Times, June 16, 1988.

762 "Armed Forces 'Temporarily Rescind' Measures," Port-au-Prince Radio Nationale [English Translation], June 16, 1988, Foreign Broadcast Information Service (FBIS) Daily Reports, June 17, 1988. 763 "Manigat on Insecurity Issue, Army Situation," Port-au-Prince Radio Nationale [English Translation], June 16, 1988, Foreign Broadcast Information Service (FBIS) Daily Reports, Latin America, June 20, 1988.
} 
the service of the nation... ${ }^{1764}$ Manigat's attempt to reform the country's Armed Forces would be sweeping, targeting 37 officers from throughout the high command, the Presidential Guard, provincial and district posts, and the police. The changes also included the retirement of Colonel Gregoire Figaro, chief of police of the Port-au-Prince, believed to be connected to the insecurity rampant throughout the capital; the transfer of Colonel Prosper Avril, former member of the CNG, out of the Presidential Guard to a staff position; and Captain Ernest Ravix, district commander of St. Marc, believed to be in charge of contraband smuggling in the region. In fact, "most of the country's district military chiefs, majors and captains who...dominated provincial and rural areas with almost dictatorial powers, were to be transferred to powerless staff jobs or to other districts far from their current posts. ${ }^{1765}$

Less than 48 hours later, Namphy would convince commanders Colonel Prosper Avril and Major Henri-Robert Augustin of the Presidential Guard, as well as Major Marc Charles of the Leopards Corps, to break him out of house arrest and orchestrate a coup against President Manigat. ${ }^{766}$ Leading the Presidential Guard's armored units, the only armored units in the country, Namphy would force Colonel Paul and his Dessalines Battalion to surrender. Forced into exile, Manigat declared that Namphy and his supporters overthrew his government because they were involved in corruption, smuggling, and insecurity, and thus resented his government. "Namphy had not been

\footnotetext{
764 "Manigat Issues Decree," Port-au-Prince Radio Nationale [English Translation], June 18, 1988, Foreign Broadcast Information Service (FBIS) Daily Reports, Latin America, June 20, 1988.

${ }^{765}$ Don A. Schanche, "Haitian General Ousts President: Strongman Escapes House Arrest, Seizes Palace in Hail of Gunfire," Los Angeles Times, June 20, 1988.

766 "Namphy Calls for 'Trust,"' Paris AFP [English Translation], June 20, 1988, Foreign Broadcast Information Service (FBIS) Daily Reports, Latin America, June 20, 1988.
} 
willing to stand by and watch certain friends of his, whom he himself had put in a number of key positions in the public administration and who were corrupt, be fired." ${ }^{767}$ Manigat also claimed that Namphy supporter, Captain Ernest Ravix, military commander of SaintMarc, was responsible for orchestrating an armed protest by the local population against efforts by his government to install a customs director. He believed that the military was directly involved in smuggling vehicles into the country, conducting inspections inside the military barracks themselves. ${ }^{768}$ The ousted president also claimed that the confrontation between Colonel Jean-Claude Paul and Namphy was due to the arrest of 11 bandits by the Dessalines Barracks soldiers. Manigat believed that elements of the military affiliated with Namphy were directly responsible for the climate of insecurity being generated during his 4 months in power. "On several occasions, the government was shocked to discover that the people carrying out these actions were members of the

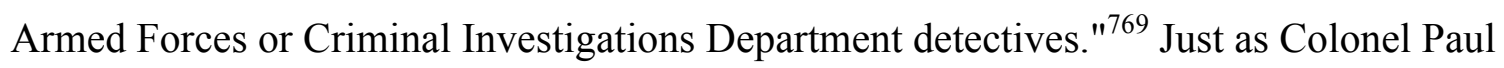
was beginning to uncover the network of criminals, Manigat argued, General Namphy sought to transfer him from the powerful position as commander of the Dessalines Battalion. $^{770}$

Namphy's showdown with Manigat regarding who was the actual head of state, would serve as an opportunity for him to completely do away with the pretense of

\footnotetext{
767 "Coup Result of Power Struggle," Port-au-Prince Radio Soleil Network [English Translation], June 24, 1988, Foreign Broadcast Information Service (FBIS) Daily Reports, Latin America, June 27, 1988.

${ }^{768}$ Ibid.

${ }^{769}$ Ibid.

770 "Says Namphy 'Mentally Ill,"' Santo Domingo Radio Mil Network [English Translation], June 21, 1988, Foreign Broadcast Information Service (FBIS) Daily Reports, Latin America, June 22, 1988.
} 
democracy or civilian government in order to establish an outright military dictatorship.

Nevertheless, in an act of cynicism, Namphy would declare that Manigat:

The president of the Republic that you chose under the Constitution of 29 March 1987 betrayed your confidence by violating this same Constitution that he solemnly swore to faithfully observe and make others observe...In violation of the Constitution and the law, he deliberately struck a blow a the Army and shook up its High Command, as well as all its cadres, in order to turn it into a docile instrument of his personal power. Through these acts, he imperiled the acquisitions of your glorious revolution of 7 February $1986 .{ }^{771}$

A day after taking power, Namphy issued a decree dissolving the Haitian Parliament. ${ }^{772} \mathrm{He}$ then carried out a series of changes and promotions in the Army, mostly annulling or countering measures taken by the ousted President Manigat. ${ }^{773}$ Afterward he formed a cabinet exclusively comprised of military men. ${ }^{774}$ In place of Parliament's Chamber of Deputies and Senate, the new military government appointed two commissions, consisting of three persons each, to "operate under the supervision of the Ministry of Interior and National Defense." ${ }^{775}$ At the local level, Namphy's government envisioned creating administrative councils, made up mostly of former

\footnotetext{
771 "Explains Power Seizure," Port-au-Prince Radio Nationale [English Translation], June 20, 1988, Foreign Broadcast Information Service (FBIS) Daily Reports, Latin America, June 21, 1988.

772 "Decree Dissolves Parliament," Paris AFP [English Translation], June 20, 1988, Foreign Broadcast Information Service (FBIS) Daily Reports, Latin America, June 21, 1988.

773 "Army Promotions, Changes," Paris AFP [English Translation], June 21, 1988, Foreign Broadcast Information Service (FBIS) Daily Reports, Latin America, June 21, 1988.

774 "Further on Cabinet," Paris AFP [English Translation], June 20, 1988, Foreign Broadcast Information Service (FBIS) Daily Reports, Latin America, June 21, 1988.

775 "Ministry of Information on New Commissions," Port-au-Prince Radio Nationale [English Translation], July 1, 1988, Foreign Broadcast Information Service (FBIS) Daily Reports, Latin America, July 5, 1988.
} 
members of the January 17 Duvalierist Parliament, "to promote participation by local populations in the management of local public affairs." 776

As the first ostensibly elected government since the ouster of Jean-Claude Duvalier fell from grace, "an atmosphere of general indifference" permeated throughout Haitian society, particularly amongst the poor and working class majority. There were no mass demonstrations for or against the ousted Manigat, or the general who ousted him. ${ }^{777}$ According to PUCH leader, Rene Theodore, "Leslie Manigat fell, and not even a dog barked after him," ${ }^{778}$ a sign of how little anyone cared for his government, condemned by the population for having compromised with orchestrators of the November 29 massacre. According to the Foreign Minister of Antigua and Barbuda, Lester Bird, Manigat's government "represented a cosmetic democracy that was always doomed to fail." ${ }^{779}$ Now that it had, perhaps it was time to push the new military government to allow for "genuine democracy."

\section{CONCLUSION}

While Manigat viewed his selection by the military on January 17 as an advancement for democracy, most of Haiti's poor and working class saw it for what it

\footnotetext{
776 "Creation of Local Affairs Councils Likely," Port-au-Prince Radio Metropole [English Translation], June 29, 1988, Foreign Broadcast Information Service (FBIS) Daily Reports, Latin America, July 1, 1988.

777 "Situation in Capital Provinces Updated," Port-au-Prince Radio Soleil Network [English Translate], June 21, 1988, Foreign Broadcast Information Service (FBIS) Daily Reports, Latin America, June 22, 1988.

778 "PUCH Leader Theodore," Port-au-Prince Radio Metropole [English Translation], June 22, 1988, Foreign Broadcast Information Service (FBIS) Daily Reports, Latin America, June 24, 1988.

779 "L. Bird - Manigat's Haiti 'Cosmetic Democracy,'" Bridgetown CANA [English Translation], June 21, 1988, Foreign Broadcast Information Service (FBIS) Daily Reports, Latin America, June 22, 1988.
} 
was, contempt for a conception of democracy that went beyond the skills and insights of a few great personalities to include them as active agents in shaping the direction of Haitian society. "We had said from the beginning that Manigat thought his ability to maneuver, skill, and intelligence could make up for the mobilization and determination of the Haitian people in their struggle to recover their freedom." ${ }^{780}$ This same criticism could be levied against a number of the prominent figures that made up the "responsible opposition," whether Marc Bazin, Louis Dejoie, or Sylvio Claude.

Manigat failed to acknowledge that Duvalierism, whatever it may have begun as, evolved into a repressive system and ideology that sought to guarantee privileges and benefits for a few, to the detriment of the many. In an underdeveloped country like Haiti, where opportunities to generate steady income, let alone wealth, are rather limited for most, those included amongst the few rarely relinquish the exorbitant privileges and benefits that accrue to them as a result of being close to power, voluntarily. Perhaps it was naïveté on the part of Manigat to believe that those who were willing to kill fellow Haitians simply for standing in line to vote, would put him into the presidency, only to allow him to single-handedly challenge what they were willing to kill to preserve. Or perhaps it was hubris.

Rather than viewing the condition of the poor and working classes in Haiti as stemming from a history of systematic repression and exclusion from the political system by the powerful, Manigat viewed their economic circumstances as a technical issue that he could address if only he was given power. Manigat did not accept that he was only

\footnotetext{
780 "Haitian Committee to Organize Political Group," Port-au-Prince Radio Soleil Network [English Translation], June 24, 1988, Foreign Broadcast Information Service (FBIS) Daily Reports, Latin America, June 29, 1988.
} 
allowed to become President because the military and other power brokers within Haiti thought that he was willing to preserve the status quo. Instead, he believed that he could generate enough international and domestic goodwill because of his pedigree as a wellrespected intellectual and political figure to push forward a reformist agenda without being opposed by those who put him in power in the first place.

Following the experiences of November 29, 1987, January 17, 1988, and June 20, 1988, the poor and working class majority understood that there was no compromising with those who traditionally despised their autonomous political mobilization and organization, whether the partisans of Duvalierism or the "responsible opposition." Instead, they rejected the politicians and political parties, in support of those who called on them to act as agents rather than subjects in the process of democratic transition. From the fall of Jean-Claude Duvalier in 1986, to his election in 1990, no one exemplified this position more than the Catholic Priest turned presidential candidate, Jean-Bertrand Aristide. 


\section{CHAPTER VI.}

\section{JUSTICE BEFORE ELECTIONS}

\section{INTRODUCTION}

What the demise of the Manigat government made abundantly clear, was that changes to the status quo distribution of resources and power in a society as vastly unequal as Haiti, even through moderate reforms, simply was not possible without confronting longstanding systems that maintained such inequality. While the subsequent overthrow of Henri Namphy by noncommissioned officers, the eventual ouster of his successor, General Prosper Avril, and the emergence of a civilian provisional government led by Ertha Pascale-Trouillot, were lauded as steps forward towards a democratic Haiti, many viewed the promise and prospect of elections as a distraction from the popular impulse for justice.

These crises throughout Haiti's democratic transition would expose a growing rift within the democratic opposition, between those who thought that elections alone, even when severely compromised, would lead the way to democracy, and those who believed that only popular mobilization in the streets, and even possible violent confrontations with Haiti's systems of unjust power and privilege, would bring the country closer to popular democracy. Jean-Bertrand Aristide's entrance into the 1990 presidential race, despite being a longstanding critic of participating in elections before Duvalierists and macoutes were brought to justice, would be an attempt to bridge the gap between the two positions, with the hope of using the momentum of the mass mobilization for elections to establish a government with a popular mandate to push forward an agenda defined by the people. Despite winning the 1990 presidential election with the overwhelming support of 
the population, it became increasingly clear that the "responsible opposition" and the international community would do as much as possible to hamstring his reformist agenda, using the logic and rhetoric of polyarchy.

\section{COMPROMISING WITH HARDLINERS}

After taking power on June 20, 1988, Henri Namphy declared that "the proof [had] been given," and it was clear that "the time [was] not yet ripe for elections in Haiti," if it ever would be. ${ }^{781}$ The military had "handed over power to an elected Government, a civilian Government, and it didn't work out." 782 According to Namphy, after February 7, 1986, the politicians returned from exile, bringing with them "foreign models" and "parties of all political persuasions" to "impose their views on Haiti..." ${ }^{783}$ The minimal consensus the military had hoped to establish with Manigat failed. Now, it was time for the Army to lead the country the way it should and ought to be led. ${ }^{784}$

This first meant doing away with the Constitution of 1987, "drawn up and ratified in an atmosphere of passion and emotionalism...stray[ing] too far from our mores, adopting elements foreign to our history and to our traditions." ${ }^{785}$ Instead, "a new, equally

\footnotetext{
781 "Namphy Says Country Not Ready for Elections," July 27, 1988, Foreign Broadcast Information Service (FBIS) Daily Reports, Latin America.

782 "No Haitian Elections, Military Ruler Declares," New York Times, June 28, 1988.

783 "Namphy on Coup Reasons, Elections, Army Role," Paris Liberation [English Translation], June 27, 1988, Foreign Broadcast Information Service (FBIS) Daily Reports, Latin America, June 30, 1988.

784 "Namphy Addresses Nation," Port-au-Prince Domestic Service [English Translation], June 20, 1988, Foreign Broadcast Information Service (FBIS) Daily Reports, Latin America, June 21, 1988.

785 "Namphy Address on New 'Democratic Charter,"' Port-au-Prince Domestic Service [English Translation], July 8, 1988, Foreign Broadcast Information Service (FBIS) Daily Reports, Latin America, July 11, 1988.
} 
democratic charter" would consolidate the acquisitions of February 6, 1986, "while taking into account Haitian reality. ${ }^{786}$

Namphy declared that his government would focus its energies on development, "stressing that the country's primary need [was] not politics but rather education, development, and jobs." ${ }^{787}$ Namphy called on all Haitians, "without distinctions of color, class, degree of wealth, religious convictions, or political ideology, ${ }^{788}$ to join the military government in helping the country move towards development. The question of development would itself be a technocratic rather than political matter. Namphy believed it was necessary to bypass the "politicians" and work directly with the people to move the country forward. The military government thus created the National Office for the Coordination of Micro-Projects, whose mission would be "to facilitate voluntary participation of the rural population in identifying their needs, defining their priorities, and implementing micro-projects retained by the executive." ${ }^{789}$ The military promised to take 15 million gourdes from the public treasury to launch an action program focused on creating 15,000 jobs for the underprivileged. ${ }^{790}$ Some of this money would be targeted to the particularly impoverished communities of Port-au-Prince, while a portion would be

\footnotetext{
${ }^{786}$ Ibid.

787 "Namphy Says Country Not Ready for Elections," July 27, 1988, Foreign Broadcast Information Service (FBIS) Daily Reports.

788 "Namphy Address on New 'Democratic Charter,"' Port-au-Prince Domestic Service, July 8, 1988.

789 "Decentralized Project Coordination Agency Formed," Port-au-Prince Radio Nationale [English Translation], July 15, 1988, Foreign Broadcast Information Service (FBIS) Daily Reports, Latin America, July 18,1988

790 "Military Government Announces Job Program," Port-au-Prince Radio Metropole [English Translation], July 20, 1988, Foreign Broadcast Information Service (FBIS) Daily Reports, Latin America, July 22, 1988.
} 
devoted to establishing irrigation systems in the countryside and the distribution of Creole pigs to poor peasant families. ${ }^{791}$ Rather than allowing the poor and working class to create their own autonomous representative bodies or choose their own representatives, the military government assigned development agents for each of the country's administrative districts, which it touted as part of its efforts to decentralize development. ${ }^{792}$ According to Namphy, dialogue and compromise with the opposition was not necessary to implementing development.

Despite Namphy's invectives against politics and politicians, a number of prominent figures within the "responsible opposition" believed that dialogue with the military government was not only still possible, but also the only way forward. At the forefront of this call for dialogue with the military regime was Marc Bazin. While he acknowledged the fact that, whether the opposition liked it or not, the Army held the reins of power, Bazin believed it was necessary for them to accept Namphy's invitation to "make a new start." ${ }^{793}$ Despite the risks, he believed that dialogue was "the only solution and would be good for the entire country in general" if not "an absolute necessity." ${ }^{194} \mathrm{He}$ proposed that the government begin "organizing a number of meetings between representatives of the Army, the administration and political parties, the private sector, the churches, the civilian society, and the unions...to quickly prepare a set of proposals

791 "Emergency Projects Detailed," Port-au-Prince Radio Nationale [English Translation], July 21, 1988, Foreign Broadcast Information Service (FBIS) Daily Reports, Latin America, July 22, 1988.

792 "Decentralized Project Coordination Agency Formed," Port-au-Prince Radio Nationale, July 15, 1988.

793 "MIDH's Bazin: Dialogue 'Absolute Necessity,"' Port-au-Prince Radio Nationale [English Translation], July 29, 1988, Foreign Broadcast Information Service (FBIS) Daily Reports, Latin America, August 2, 1988.

${ }^{794}$ Ibid. 
and recommendations designed to allow the dialogue to begin quickly so as to save this country..." ${ }^{795}$ Serges Gilles of the Nationalistic and Progressive Revolutionary Party of Haiti (Panpra) would second Bazin's proposal for dialogue as the only "means for democrats to extricate themselves," rejecting the notion that this was "the same as the calculated risk that former President Leslie Manigat took in last 17 January's fraud-ridden election..." ${ }^{796}$ Bazin and Gilles were not without their critics.

According to Sylvio Claude's PDCH, dialogue was not possible with Namphy after "all the evil deeds that have been committed in Haiti since February 1986," and particularly impossible "without the Constitution of 1987, which is the expression of the people's rights, the expression of the national sovereignty." ${ }^{797}$ Rather than seek dialogue with dictators, PDCH called on all those who sought to speak for the Haitian people, to begin the dialogue "with the people first, in order to verify the people's mandate." ${ }^{798}$ For many within the popular movement, Bazin's call for dialogue showed a particular contempt for even the most reductive understandings of democracy. Representatives from 12 lay groups ${ }^{799}$ from throughout the country would issue a statement declaring that:

${ }^{795}$ Ibid.

796 "Party Founder Favors Bazin Dialogue Proposal," Port-au-Prince Radio Soleil Network [English Translation], August 5, 1988, Foreign Broadcast Information Service (FBIS) Daily Reports, Latin America, August 9, 1988.

797 "PDCH on Bazin Message, Talks with Army," Port-au-Prince Radio Soleil Network [English Translation], August 1, 1988, Foreign Broadcast Information Service (FBIS) Daily Reports, Latin America, August 2, 1988.

${ }^{798}$ Ibid.

${ }^{799}$ Christian Youth Workers (Jenes Ouvriye Kretien), Catholic Action Workers (Aksyon Ouvrier Katolik), the Fraternity of Committed Laymen (Fraternite Laik Angaje, Frala), the Justice and Peace Committee (Komite Jistis ak Lape), Solidarity Among Christian Youth (Solidarite Jen Kretyen), the Committee of Small Grassroots Churches (Ti Kominote Legliz), Solidarity Among Youth (Solidarite Ant Jen), the Youth Pastoral Committee of Saint Gerard (Komite Pastoral Jen, Sen Jerar), and Keep-An-Eye-on-Them 
The ideas and desires of the majority of the Haitian people must be pursued. The will of no person, nor any group of people, can be substituted for the will of the majority of the Haitian people. This means that a person who has appointed himself chief of state represents nothing. The will of a group of people making their own law in Haiti cannot represent anything. Thus, the only government with a right to run the country is a government on which a majority of people in the country agree.... ${ }^{800}$

While the likes of Bazin and Gilles were calling for dialogue with the military regime, the level of repression against the popular organizations that openly challenged a return to Duvalierism was consistently escalating. Only two days after taking power, the Namphy government responded to a strike by five hundred workers at a Governmentowned flower mill in protest against the reinstatement of corrupt managers, by dismissing union leaders and over 80 other workers at gunpoint. ${ }^{801}$ In the second day of the strike, the reinstated director would come to work carrying an Uzi, while members of the military carried out the dismissals. ${ }^{802}$ According to CATH, the Autonomous Organization of Haitian Workers,

Ever since the military government seized power, employers have become more arrogant and more aggressive. They tell you outright that they are in power now. And it's true. They really are, because throughout the world, no military government has ever done anything for the masses. Such governments are never into benefiting the people. They are always on the side of the wealthy bourgeoisie. ${ }^{803}$

Cooperation Group (Konbit Veye Yo).

800 "Lay Groups Call for Change," Port-au-Prince Radio Soleil Network [English Translation], August 9, 1988, Foreign Broadcast Information Service (FBIS) Daily Reports, Latin America, August 11, 1988.

${ }^{801}$ Joseph B. Treaster, "New Haitian Regime Reportedly Jails 16 Foes," New York Times, June 23, 1988.

802 "Further on Dismissals of Workers at Flour Mill," Port-au-Prince Radio Haiti-Inter [English Translation], June 23, 1988, Foreign Broadcast Information Service (FBIS) Daily Reports, Latin America, June 24, 1988.

803 "Further on Labor Conflict at Garment Factory," Port-au-Prince Radio Haiti-Inter [English Translation], July 22, 1988, Foreign Broadcast Information Service (FBIS) Daily Reports, Latin America, July 27, 1988. 
A month after the military returned to power, Lafontant Joseph, former senatorial candidate in the cancelled November 1987 elections, described by many as "the lawyer of laborers, peasants, and workers in general," would be violently murdered by unknown assailants. ${ }^{804}$ This would be followed by the killing of 10 members of the Labadie Youth Movement in the Commune of Petite Riviere de l'Artibonite. It was noted that the murdered Lafontant Joseph had been the group's legal representative. ${ }^{805}$ These murders coincided with what many believed was the open reemergence of macoutes groups. Joseph and his wife, Raymonde, of the Women's Committee Against Torture, were primary targets of a hit list being circulated throughout the country by macoutes forces. ${ }^{806}$

On August 18, 1988, the military government's development adviser and former deputy under Duvalier, Luc Felix, would organize a large gathering in Jeremie to inaugurate the formation of what he called the Club Fraternite. Felix invited those who were still "living in caves," a reference to macoutes who went into hiding during the dechoukaj, to join the club, promising that they would have the protection of the police and the Army against those who would destroy the country by making Haiti communist. ${ }^{807}$ Felix exclaimed that General Namphy was ready to give them roads,

\footnotetext{
804 "Station Comments," Port-au-Prince Radio Soleil Network [English Translation], July 12, 1988, Foreign Broadcast Information Service (FBIS) Daily Reports, Latin America, July 13, 1988.

805 "10 Youths Reportedly Killed in Artibonite," Port-au-Prince Radio Soleil Network [English Translation], August 16, 1988, Foreign Broadcast Information Service (FBIS) Daily Reports, Latin America, August 17, 1988.

806 "CATH Reacts," Port-au-Prince Radio Soleil Network [English Translation], July 12, 1988, Foreign Broadcast Information Service (FBIS) Daily Reports, Latin America, July 13, 1988.

807 "Radio Soleil Views Meeting," Port-au-Prince Radio Soleil Network [English Translation], August 18, 1988, Foreign Broadcast Information Service (FBIS) Daily Reports, Latin America, August 23, 1988.
} 
water, houses, and access to credit without interest, if they would defend the current regime. ${ }^{808}$ Those who observed the gathering from a distance noted that many of the participants were former macoutes who expected to be armed by the government. ${ }^{809}$ The Namphy government would subsequently declare assemblies forbidden unless an Army member was allowed to take part. ${ }^{810}$

In this context of escalating repression of the popular organizations, the Union of Democratic Patriots (Union des Patriotes Democrates, UPD), headed by Rockefeller Guerre, called on the population to rid themselves of Namphy's military government. The UPD not only rejected Bazin's call for dialogue, it also rejected the campaign by Sylvio Claude and other politicians for the reinstatement of the Constitution of 1987. For the UPD, the Constitution was not enough to challenge a government that did not represent the will of the Haitian people nor respect their basic human rights. "The UPD position is in keeping with a democratic philosophy...When a long series of abuses and usurpations, all converging invariably toward the same end, clearly show that there is a design to subject the people to absolute despotism, the people have the right and even the duty to throw off the yoke of such a government and to give themselves new guarantors of their future security." ${ }^{811}$ Evidence of this emergent absolutism was not difficult to find.

\footnotetext{
${ }^{808}$ Ibid.

809 "Former Deputy on Creation of 'Club Fraternite,"' Port-au-Prince Radio Soleil Network [English Translation], September 5, 1988, Foreign Broadcast Information Service (FBIS) Daily Reports, Latin America, September 9, 1988.

810 "Peasant Group Protests Restrictions on Assembly," Port-au-Prince Radio Soleil Network [English Translation], August 23, 1988, Foreign Broadcast Information Service (FBIS) Daily Reports, Latin America, August 24, 1988.

811 "New Party Urges People to Overthrow Government," Port-au-Prince Radio Metropole [English Translation], August 30, 1988, Foreign Broadcast Information Service (FBIS) Daily Reports, Latin
} 


\section{A PEOPLE'S DEMOCRACY}

Aristide first came to prominence in 1985, when, despite the legacy of repression, even against members of the Church, he issued a Mass rebuking the Jean-Claude Duvalier regime. Many would come to cite this mass as lighting the fire of the mass movement that would eventually remove Jean-Claude from power. According to one political observer of this period, Aristide was "the only real leader...thrust forward by the coup against the Duvaliers" who "kept the same line throughout...anti-Government, antimilitary and anti-imperialism." 812

What particularly distinguished Aristide from the "responsible opposition," was his conviction that a system that relied on the unjust use of violence to subjugate and exclude the poor from politics could not be compromised with. Rather, such a system had to be confronted by the mobilization of the poor and working class masses, whose use of force to undo such a system must by definition be considered the epitome of democratic justice. Aristide appealed to the grassroots organizations particularly because he rejected the ethos of civility and non-violence called for by the "responsible opposition" in the face of escalating violence directed at them by the military government.

In fact, Aristide sought to legitimize the right to self-defense and armed struggle in his sermons, situating the resistance movement against Haiti's military within the context of the Bible. A few months prior to the November 29 election-day massacre, Aristide would use a passage from the Bible that he believed reflected what Jesus called on his followers to do as they faced the threat of death at the hands of their adversaries,

America, August 31, 1988.

${ }^{812}$ Howard W. French, "Attack on Priest Called Haiti Catalyst," New York Times, September 24, 1988. 
just as the poor people in Haiti faced the threat of death at the hands of the macoutes. ${ }^{813}$ Aristide noted that, while the Church had always told the people that Jesus did not agree with the use of weapons, here was a passage in the Bible, where Jesus, increasingly encircled by his enemies, called on his followers who did not have swords, to sell their garments in order to obtain them. He thus asked whether, "inside Haiti, where Article 268 of the Constitution asks that people who wish to possess weapons be given the right to possess weapons in their homes to use for the purpose of legitimate defense-in the name of that faith in Jesus Christ; and with the Constitution that Haiti has-would it be a sin? Would it be a crime for us to have weapons at home with which to defend ourselves from the terrorist army?" ${ }^{814}$ Aristide believed that it was irresponsible for him, the Church, or anyone to chastise the poor, who could only challenge the increasing repression of the macoutes' and military's guns with their bare hands and farm tools.

Aristide also believed it was irresponsible to ask the people to participate in the elections of November 1987, or any future elections for that matter, while macoutes continued to maintain power. The poor and working class could not face the systematic terror directed at them through elections. He was therefore particularly opposed to the people's participation in elections organized by forces that relied on repression and exclusion to maintain their status. While even the leadership of some of the grassroots organizations were willing to compromise on participating in elections despite the escalating threat of violence, Aristide remained one of the few public figures to

\footnotetext{
813 "Priest on Role of Church in 'Struggle,'" Port-au-Prince Domestic Service [English Translation], August 17, 1987, Foreign Broadcast Information Service (FBIS) Daily Reports, Latin America, August 19, 1987.

${ }^{814}$ Ibid.
} 
unequivocally reject elections organized by the CNG. He vehemently denounced "the complicity of U.S. imperialism" in agreeing "to massacre the Haitian people through the CNG," which was "trying to organize false elections to have a macoute in power." 815 Aristide would be closely aligned with the popular organizations most resistant to defining democracy exclusively as the holding of elections. Central to the opposition in Port-au-Prince was the People's National Assembly (the APN), whose founding congress on March 7-8, 1987 was hosted by Aristide at his St. Jean Bosco parish. "The APN dedicated itself to become an independent and combative popular organization which would challenge the opportunism and treachery of Haiti's democratic bourgeoisie and petty bourgeoisie, who advocated, even then, collaboration with imperialism and accommodation with Duvalierism." ${ }^{816}$ While the "responsible opposition" generated international support for elections in 1987, groups like the APN believed that democracy could only be established through the mobilization of the popular sectors. The APN "said that no elections [were] possible under the CNG and the CEP," because "the CNG [had] no moral prestige with which to organize elections...So we say: Down with all dishonest elections...." ${ }^{817}$ Aristide, the APN, and the other popular organizations that boycotted the November 1987 elections would declare anyone who pushed the population towards elections before the just power of the people could restructure Haiti's institutions so that

\footnotetext{
815 "Aristide Calls for 'Revolution,"' Paris AFP [English Translation], December 2, 1987, Foreign Broadcast Information Service (FBIS) Daily Reports, Latin America, December 3, 1987.

816 "The Charlemagne Perale Congress: APN Launches Anti-Occupation Campaign," This Week in Haiti 13, no. 11, June 7-13, 1995, http://www.hartford-hwp.com/archives/43a/083.html.

817 "APN Opposes Elections," Port-au-Prince Radio Nationale [English Translation], September 16, 1987, Foreign Broadcast Information Service (FBIS) Daily Reports, Latin America, September 18, 1987.
} 
they ceased to exclude and oppress the poor majority, accomplices to the election-day violence.

In the aftermath of the massacre, Aristide levied a particularly strong rebuke against the U.S.'s role in supporting the elections. He declared that it was clear that the American government was a co-conspirator in the election-day violence. "We have been saying we refused to enter elections with the CNG. But the Americans didn't hear; they didn't see. Just like a big overlord they said, 'Okay, we have to have elections...' The Haitian people see that the American government is responsible--along with the Haitian government---for those who have died." ${ }^{818}$ Aristide would make a similar judgment of the Catholic Church hierarchy for having galvanized support for the November 1987 elections when many in the Ti Legliz were against them. According to Aristide, "neither the apostolic nuncio nor certain other bishops were able to hear the voice of God's people and obey it. They preferred to organize themselves to send people out to participate in elections. What did this lead to? To bloodshed." ${ }^{819}$ Rather than issue commands from on high, Aristide believed it was imperative that the Church hierarchy, the nuns, and the priests:

Listen, now more than ever, to the voice of God's people, the majority of whom see that in order for things to change, there must be participation by the entire mass of God's people, in unity, in communion with the Episcopal Conference...the Episcopal Conference cannot simply decide to take it upon itself to decide for the masses of the people. Rather, the

\footnotetext{
818 "Interview with Pere Jean Bertrand Aristide, St. Jean Bosco Church," Haiti Dechoukaj Collection, Box 1, Folder 3 - Interviews, 1987, December 6, 1987.

819 "Father Aristide on Church 'Silence' After Coup," Port-au-Prince Radio Antilles Internationales [English Translation], June 30, 1988, Foreign Broadcast Information Service (FBIS) Daily Reports, Latin America, July 5, 1988.
} 
decision must be reached together with the masses, so that it will not lead to corpses and to bloodshed... 820

Even organizations tied to the popular movement, such as KID and Conacom, which at one time believed that elections were possible under military rule, began denouncing leaders that claimed to speak for the masses. One of the biggest mistakes KID acknowledged, was "that it did not protest vehemently enough against all the various, seemingly sincere wheeler-dealers who pretended to be defending the Haitian people's interests but who were really serving their own personal ambitions...These wheeler-dealers [had] yet to admit their errors to the people...their own responsibility in the 29 November massacre." ${ }^{821}$ From that point on, KID would call all organizations claiming to be part of the people's camp to "make a clear commitment to establishing the people's struggle on the basis of unity of organization, unity of strategy in the battle plan, and unity of action--which are indispensable for the real democracy that the Haitian people need..." ${ }^{822}$ They would unite principally behind the call for justice before elections. In a limited sense, they called for legal justice to be carried out for those who were murdered as a result of the various Duvalierist governments. In a broader sense, their call for justice referred to the overturning of unjust structures of power, privilege, and domination that had existed in Haiti since before 1804. He acknowledged that in Haiti's situation, democracy had to be revolutionary. Aristide "never believed in

\footnotetext{
${ }^{820}$ Ibid.

821 "Democratic Unity Group Marks Anniversary," Port-au-Prince Radio Nationale [English Translation], March 22, 1988, Foreign Broadcast Information Service (FBIS) Daily Reports, Latin America, March 23, 1988.

${ }^{822}$ Ibid.
} 
elections," or that "elections would bring a solution." Instead, he believed that the solution to the people's oppression would "be the child of a true revolution." 823

Aristide simply did not believe it was possible for the poor and working classes to dismantle the structures of economic and social inequality and exclusion through elections. He framed the struggle for democracy in Haiti in ways that most public figures, particularly within the Church, were willing to do: in terms of class struggle. At a May 14,1988 rally celebrating the 8 -year anniversary of the labor organization, CATH, Aristide "opened the rally with a request for blessings not from the bigshots' God, he said, but from the God of the poor..." asking Him "to help all CATH members, all peasants, all workers, and all the poor by sweeping away all the evil people seeking to crush and mistreat them." ${ }^{824} \mathrm{He}$ continued, praising

CATH's efforts as a labor union to bring a little light to the workers, who can now distinguish their friends from their enemies, and to make the workers understand the situation: the property owners are abusing them, the state is crushing them, and other reactionary sectors are roughing them up. Father Aristide said that only the proper organization of $\mathrm{CATH}$, of unions, other sectors that love the masses, workers, and peasants, can lead to proper change, meaning real change. ${ }^{825}$

Aristide rejected the notion that the poor and working class were to simply be

passive subjects, left outside of the political process. Instead, Aristide was a leading voice in calling on the military regime, the "responsible opposition," and the international

\footnotetext{
823 "Father Aristide on Church 'Silence' After Coup," Port-au-Prince Radio Antilles Internationales [English Translation], June 30, 1988, Foreign Broadcast Information Service (FBIS) Daily Reports, Latin America, July 5, 1988.

824 "Workers Organization Holds Anniversary Rally," Port-au-Prince Radio Soleil Network [English Translation], May 16, 1988, Foreign Broadcast Information Service (FBIS) Daily Reports, Latin America, May 19, 1988.

${ }^{825}$ Ibid.
} 
community, to recognize the political agency of the poor, to view the transition to democracy as a process of empowering the poor and marginalized. CATH's Secretary General, Yves Antoine Richard, would echo these sentiments at the same rally with a call to the people to continue mobilizing for a revolution, so that a participative democracy "in which the masses feel they are in power, in which the masses feel that they are directing their country politically, economically, and socially," may bloom. ${ }^{826}$

What made Aristide and the Ti Legliz particularly threatening was their ability to progressively usurp the moral authority of the Catholic Church. Aristide increasingly highlighted the growing division within the Church between the Church hierarchy and the poor and working class majority who sat in its pews. He specifically highlighted the complicity of segments of the Church with the powerful. While the majority of the church, made up of the laity, was under the table, the majority of bishops were seated at the table with the bourgeoisie. ${ }^{827}$

Aristide persistently challenged whether or not the word of the Church should be defined by statements made by the Church hierarchy, or by the positions taken by the various grassroots lay organizations that reflected the sentiments of the majority. In speaking about the Catholic Church's supposed silence after the rigged elections on January 19, 1988, and Manigat's ouster the following June, Aristide rejected the notion that the bishops were the Catholic Church. "It is false when people say, simply because the bishops have not spoken out, that the church has not spoken. The bishops are not the

\footnotetext{
${ }^{826}$ Ibid.

827 "1st Anniversary of Freycinau 'Ambush' Marked," Port-au-Prince Radio Soleil Network [English Translation], August 24, 1988, Foreign Broadcast Information Service (FBIS) Daily Reports, Latin America, August 26, 1988.
} 
church...The bishops are members of the church. They are the elder brothers in the church. The church is God's people, as defined by Vatican II. ${ }^{1828}$ For Aristide, the church had consistently spoken through the many church groups that made up the Til Legliz. "For example, on 7 February 1986 the bishops called for reconciliation, reconciliation. The rest of the church, the majority, saw farther ahead, spoke more clearly, and said, yes reconciliation, but justice must also be done..." ${ }^{829}$ Aristide rejected the hierarchical nature of the church, and increasingly called for the church to take on a more democratic orientation within itself. As the Church hierarchy resisted, a rift would emerge between it and what many began to call the People's Church or the Church of the Poor.

Lying in the middle of the massive slum city of La Saline, a living embodiment of injustice itself, Aristide's St. Jean Bosco Church became an epicenter for the popular organizations that shared his belief in mobilizing to undo Haiti's historical systems of injustice. St. Jean Bosco would increasingly come to symbolize the People's Church, as the poor and orphaned youth of the impoverished neighborhoods of Port-au-Prince, joined the student organizations, the labor unions, the women's organizations, the peasant groups, and popular organizations to challenge the various dictatorial regimes to emerge in the wake of Jean-Claude Duvalier's demise. This set Aristide and his St. Jean Bosco parish on a collision course with Namphy's military regime. On September 11, 1988, nearly 100 men wearing red armbands and red shirts, armed with revolvers, steel rods, pointed sticks, machetes, and knives, would burst into the church during Aristide's

\footnotetext{
828 "Father Aristide on Church 'Silence' After Coup," Port-au-Prince Radio Antilles Internationales [English Translation], June 30, 1988, Foreign Broadcast Information Service (FBIS) Daily Reports, Latin America, July 5, 1988.

${ }^{829}$ Ibid.
} 
Sunday mass, launching one of the vilest attacks on the population since the November 1987 election-day massacre, killing 11 churchgoers and wounding 77 more. The attack coincided with opposition leaders' call for the population to wear white in support of the reinstatement of the Constitution of $1987 .{ }^{830}$ Aristide would only be able to get away as a result of the protection of a number of his loyal parishioners. Growing evidence implicated the Mayor of Port-au-Prince, former Duvalier era army colonel and police chief, Frank Romain, who likely received backing from the Namphy government, given threatening statements made by the General at City Hall only a few days prior to the incident. ${ }^{831}$ When asked about the assault, Romain declared that Aristide had been "justly punished" and that "he who sows the wind reaps the storms." 832

\section{STIFLING THE SEPTEMBER 17 MOVEMENT}

On September 17, 1988, the message of upending unjust institutions would infiltrate the barracks of Haiti's Armed Forces, leading to a coup d'état against Namphy by junior officers within the Presidential Guard, and the mobilization of regular soldiers (Ti Soldats) across the country against higher-ups they believed were responsible for preserving macoutism within the military. Sergeant Joseph Hébreux, leader of the movement of non-commissioned officers, was the first to appear on television to justify

\footnotetext{
830 "5 Dead, 70 Injured 11 Sep," Paris AFP [English Translation], September 12, 1988, Foreign Broadcast Information Service (FBIS) Daily Reports, Latin America, September 12, 1988.

831 "Church Attacks Instrumental," Port-au-Prince Radio Soleil Network [English Translation], September 18, 1988, Foreign Broadcast Information Service (FBIS) Daily Reports, Latin America, September 19, 1988.

${ }^{832}$ Robert Pear, "U.S. Officials Say New Haitian Rulers Are Like the Old Ones," New York Times, September 19, 1988.
} 
the coup against Namphy based on a "desire to restore the prestige of Haiti, sullied by so many actions that have revolted the sensibilities of the Haitian people...as well as those of the enlisted men of the FADH, who can no longer hold their heads high." ${ }^{833}$ Despite resistance from some of the soldiers, General Prosper Avril would be appointed the new head of state to replace Namphy as the result of a compromise between senior officers, sergeants, and the non-commissioned officers represented by Hébreux. "Sergeant Hébreux had been the soldier's first choice as President," but he was afraid of the job, so they took their chances with Avril. ${ }^{834}$ The consensus amongst them was that he was the "most capable officer, in view of his vast political military experience, to satisfy the people's demands." ${ }^{835}$ In a proclamation read during the broadcast with Hébreux, Avril declared that this new government envisioned a "country where freedom flourishes, where human rights are guaranteed, and where dialogue is the basis of national reconciliation. ${ }^{836}$

While the senior officers were able to maneuver around the reform-minded Heubreux to place Prosper Avril, their preferred choice, at the head of the new government, a growing linkage was occurring across the country between what came to be known as the September 17 Movement, led by the enlisted men, and the grassroots

\footnotetext{
833 "Enlisted Men Appoint Avril New Leader," Port-au-Prince Radio Nationale [English Translation], September 18, 1988, Foreign Broadcast Information Service (FBIS) Daily Reports, Latin America, September 19, 1988.

${ }^{834}$ Joseph B. Treaster, "The General and the Sergeant: Confreres in Haiti," New York Times, October 3 , 1988.

835 "Presidential Guard Involved," Paris AFP [English Translation], September 18, 1988, Foreign Broadcast Information Service (FBIS) Daily Reports, Latin America, September 19, 1988.

836 "Leaders Justify Coup," Paris AFP [English Translation], September 18, 1988, Foreign Broadcast Information Service (FBIS) Daily Reports, Latin America, September 19, 1988.
} 
people's movement for popular democracy. According to one of the enlisted soldiers, all of the crooked acts by the military were being orchestrated by "certain bigshots, who [were] tolerating a number of violent acts because they [were] not willing to lose...certain privileges, such as big cars, big houses, millions of dollars..." ${ }^{837}$ According to the soldiers, "as long as the majority of these higher-ups [were] still on the scene, nothing [could] change for the young officers, the enlisted men, and the Haitian people in general...There [was] at present a dawning of awareness among the enlisted men..."${ }^{183}$ What followed was the mobilization of enlisted men across the country to purge Duvalierist and macoute officers from their posts, dropping them off at the Army General Headquarters, where they waited for them to be imprisoned by the new government. They declared that, "in order to realize democracy, it [was] necessary for the Duvalierists to be out of the picture. As long as they [were] around, commanding and in power, democracy [would] never be able to get a foothold..." ${ }^{839}$ In Gonaives, soldiers rallied to demand the immediate departure of their district commander ${ }^{840}$ as 8,000 people took to the streets in support of them. "The soldiers, who were out with the people, told us these individuals were the ones muzzling the people and obstructing democracy." ${ }^{841}$ As two

\footnotetext{
837 "Soldier Tells of Feelings About 'Higher-Ups,"' Port-au-Prince Radio Soleil Network [English Translation], September 19, 1988, Foreign Broadcast Information Service (FBIS) Daily Reports, Latin America, September 20, 1988.

${ }^{838}$ Ibid.

839 "Labor Unrest, 'Uprooting' Spread," September 29, 1988, Foreign Broadcast Information Service (FBIS) Daily Reports.

840 "Removals Sought in Gonaives," Port-au-Prince Radio Metropole [English Translation], September 20, 1988, Foreign Broadcast Information Service (FBIS) Daily Reports, Latin America, September 21, 1988.

841 "Gonaives Supports Enlisted Men," Port-au-Prince Radio Soleil Network [English Translation], September 20, 1988, Foreign Broadcast Information Service (FBIS) Daily Reports, Latin America, September 21, 1988.
} 
more Haitian Army commanders were removed by their soldiers, these men declared that they would "establish democracy once and for all, and...rid the Army of Duvalier, Namphy, and Manigat supporters."' ${ }^{842}$ The purge would impact officers from across the Armed Forces, from the Navy and the Air force, to the Leopard Corps and the police. When it would all be said and done, "nearly 60 Haitian army officers, many of them considered powerful and influential" were swept out of the armed forces. ${ }^{843}$

Alongside these sackings, the enlisted soldiers hunted down members of the notorious Criminal Investigations Department and partisans of Port-au-Prince mayor Frank Romain, accused of orchestrating the September 11 attack on St. Jean Bosco parishioners that sparked the coup d'état and subsequent dismissals. Enlisted men would arrest David Philogene, the Opak section chief accused of carrying out the August 1987 mob killing of Louis Eugene Athis, leader of the political party Modelh. ${ }^{844}$ Those they did not kill themselves, they turned over to the crowds, who then stoned or hacked them to death. ${ }^{845}$ A number would have their corpses burned on "a pyre set near the St. Jean Bosco Church" itself, ${ }^{846}$ a display of what they called "the people's justice." ${ }^{147}$

\footnotetext{
842 "Soldiers Call for Democracy," Paris AFP [English Translation], September 20, 1988, Foreign Broadcast Information Service (FBIS) Daily Reports, Latin America, September 21, 1988.

${ }^{843}$ Joseph B. Treaster, "Many in Haiti Wonder Who is Really in Charge," New York Times, September 25, 1988.

844 "Enlisted Men Arrest Suspect in Athis Murder Case," Port-au-Prince Radio Soleil Network [English Translation], September 29, 1988, Foreign Broadcast Information Service (FBIS) Daily Reports, Latin America, October 3, 1988.

845 "Manhunts, Lynchings in Capital Reported," Port-au-Prince Radio Metropole [English Translation], September 20, 1988, Foreign Broadcast Information Service (FBIS) Daily Reports, Latin America, September 21, 1988.

${ }^{846}$ Howard. W. French, "Soldiers Draw the Line in Haiti," New York Times, September 25, 1988.
} 
While Dr. Louis Roy, one of the crafters of the 1987 Constitution, believed that "vigilantism" was a concern, he also acknowledged that the 1986 purge following the departure of Jean-Claude had "stopped far too short" and such purges were unavoidable given that the people could not "leave it to the courts. ${ }^{1848}$ In the town of Côtes-de-Fer, $185 \mathrm{~km}$ south of Port-au-Prince, soldiers actually supported the establishment of a People's Court "made up of the town's population, who serve[d] as jurors, while the heads of the neighborhood committees act[ed] as judges." ${ }^{849}$ According to the youth groups who organized the court, "officials of the fallen regimes--from President Duvalier's to Namphy's--[were] judged by this court...The accused people [were] not mistreated, and [were] given every chance to speak during the trial--to give their opinion, say what they [thought] freely, and defend themselves." ${ }^{850}$ The People's Court specifically questioned macoutes government officials about stolen community land and money. ${ }^{851}$

For many, this was the first time they had witnessed enlisted men playing a central and autonomous role in the country's politics, demanding that the Avril government pursue the disarming of the Tontons Macoutes, a transition to civilian rule,

\footnotetext{
${ }^{847}$ Ibid.

${ }^{848}$ Ibid.

849 "'People's Court' Tries Former Officials," Port-au-Prince Radio Soleil Network [English Translation], September 29, 1988, Foreign Broadcast Information Service (FBIS) Daily Reports, Latin America, September 30, 1988.

850 "Soldiers Break Up Cotes de Fer People's Court," Port-au-Prince Radio Soleil Network [English Translation], October 7, 1988, Foreign Broadcast Information Service (FBIS) Daily Reports, Latin America, October 11, 1988.

851 "'People's Court' Tries Former Officials," Port-au-Prince Radio Soleil Network [English Translation], September 29, 1988, Foreign Broadcast Information Service (FBIS) Daily Reports, Latin America, September 30, 1988.
} 
and improvements in the living conditions of the population. ${ }^{852}$ Nevertheless, many were doubtful that the noncommissioned officers would remain an effective check on Avril's intrigues. For one, Avril had a long history of serving as close advisor and confidant to a number of Duvalierist governments. Moreover, General Avril held a law degree, and had training from Navy and Marine Corps installations in the United States, ${ }^{853}$ whereas the noncommissioned officers were largely young, uneducated, and most importantly, inexperienced. ${ }^{854}$ That said, Reagan White House spokesman Marlin Fitzwater indicated that though "the Administration saw little difference between General Avril's Government and that of General Namphy," it was interested in seeing who was appointed to key positions in the Government, which would give the U.S. "a good feel for how he intend[ed] to proceed." ${ }^{855}$

While the coup sparked a growing movement linking an increasingly reoriented Haitian Army to the grassroots movement for democracy, Prosper Avril would use his position as provisional president to contain what the military hierarchy feared was a growing radicalism both within its ranks and in Haitian society more broadly. While Avril had served as "Namphy's right arm," what he understood that Namphy did not was that the exclusion of the "responsible opposition" and brazen use of violence against peaceful churchgoers, only served to increase the legitimacy of Aristide and the

\footnotetext{
${ }^{852}$ Joseph B. Treaster, "The General and the Sergeant: Confreres in Haiti, New York Times, October 3, 1988.

${ }^{853}$ Ibid.

${ }^{854}$ Joseph B. Treaster, "Many in Haiti Wonder Who is Really in Charge," New York Times, September 25, 1988.

${ }^{855}$ Robert Pears, "Washington Warns Haiti on Indicted Colonel," New York Times, September 20, 1988.
} 
grassroots organizations' message that confrontation was the only way to undo the institutions that preserved Haiti's unjust reality.

Therefore, Avril adopted a public policy of open dialogue with the "responsible opposition," while covertly suppressing the September 17 movement of the Ti Soldats and the grassroots organizations. Upon becoming the transitional president with Hébreux by his side, Avril announced that they would form a mostly civilian cabinet, ${ }^{856}$ which would be "indispensable transition toward the implantation of democracy, which is the final objective of the military government." ${ }^{857}$ Though many within the Haitian private sector, the political class, and U.S. foreign policy establishment were "skeptical of General Avril because he was a trusted aide of the Duvaliers" they were "encouraged by the general's assertion that he [saw] himself as a transitional figure on the road to elections..." ${ }^{858}$ According to one businessman, while Avril was not necessarily any better than the others who worked with Duvalier, he was smart, not known to be cruel, and most importantly, he promised to restart the democratic process again. ${ }^{859}$ Members of the Federation of Private Sector Associations of Haiti and the Haitian Manufacturers Association would petition the U.S. to release some of the $\$ 70$ million in aid suspended since the November 1987 election-day massacre, because "they feared that no leader

\footnotetext{
856 "Army Demands Democracy," Paris AFP [English Translation], September 18, 1988, Foreign Broadcast Information Service (FBIS) Daily Reports, Latin America, September 19, 1988.

857 "Avril Addresses Nation, Newly Installed Cabinet," Port-au-Prince Domestic Service [English Translation], September 19, 1988, Foreign Broadcast Information Service (FBIS) Daily Reports, Latin America, September 20, 1988.

${ }^{858}$ Joseph B. Treaster, "Haitian Struggles to Consolidate Power," New York Times, September 22, 1988. ${ }^{859}$ Ibid.
} 
could gain sufficient popular support to govern without an infusion of money." ${ }^{860}$ Despite being encouraged by General Avril's words, and the civilian cabinet, a U.S. Embassy spokesman believed that his government needed to do more in terms of securing human and civil rights, stemming drug trafficking, and making clear progress towards democracy, before action would be taken by the U.S. Government regarding aid. ${ }^{861}$ In his first address to the nation, Avril declared that the "people [were] waiting-and legitimately so--for us to prove to them, through our actions, that we truly wish and are able to serve their cause, with security and order reestablished, in an impartial manner, and within the framework of permanent dialogue with them..." ${ }^{862}$ Nearly immediately, a number of prominent members of the "responsible opposition" declared their willingness to talk to the new General in the presidential palace. Former presidential candidate, Gerard Gourgue of the FNC, would declare in a statement to Radio Antilles Internationales, that "Avril seem[ed] to be 'an open person,' to whom a vote of confidence and some time must be given," and that he and the FNC were "willing to talk to anyone who [had] good faith and goodwill." 863 Avril subsequently hosted a series of meetings with Gourgue, Sylvio Claude of the PDCH, Louis Dejoie of PAIN, Marc Bazin of the MIDH, Serge Gilles of the BIP, Victor Benoit of Conacom, and, in what would be

\footnotetext{
${ }^{860}$ Joseph B. Treaster, "Haitians See Financial Crisis and Plead for Aid," New York Times, September 24, 1988.

${ }^{861}$ Ibid.

862 "Avril Addresses Nation, Newly Installed Cabinet," Port-au-Prince Domestic Service [English Translation], September 19, 1988, Foreign Broadcast Information Service (FBIS) Daily Reports, Latin America, September 20, 1988.

863 "Leaders Reaction Noted," Paris AFP [English Translation], September 19, 1988, Foreign Broadcast Information Service (FBIS) Daily Reports, Latin America, September 20, 1988.
} 
highlighted as a historic first, the head of the Haitian Communist Party (PUCH), Mr. Rene Theodore. ${ }^{864}$ The meetings mostly focused on establishing a timetable for elections, the formation of a Provisional Electoral Council, and possible amendments to the Constitution of $1987 .{ }^{865}$ Afterwards, Dejoie announced that the Avril government was "completely in accord with the democratic process," while Bazin declared that "Haiti would seem to no longer be a country that is dominated by its army, but a country with an army that is at the disposal of the country..." ${ }^{866} \mathrm{He}$ called the meeting "a triumph for the idea of dialogue," arguing that "as long as we can talk to the military government in Haiti everything [was] possible..." 867

Support for the Avril regime amongst the "responsible opposition" and the international community would increase with the dismissal of Colonel Jean-Claude Paul of the Dessalines Battalion on October 2, 1988. While initially after coming to power Avril considered naming Colonel Paul the commander-in-chief of the army, this would be ruled out by U.S. Ambassador, Brunson McKinley, who declared such a move an impediment to the restoration of aid considering Paul's Federal grand jury indictment on drug trafficking charges. ${ }^{868}$ Understanding that without the release of this aid money, his

\footnotetext{
864 "President Avril, 'Major Political Leaders' Meet," Port-au-Prince Radio Nationale [English Translation], September 28, 1988, Foreign Broadcast Information Service (FBIS) Daily Reports, Latin America, September 29, 1988.

865 "Avril, Claude Discuss Election Prospects," Port-au-Prince Radio Metropole [English Translation], September 23, 1988, Foreign Broadcast Information Service (FBIS) Daily Reports, Latin America, September 26, 1988.

${ }^{866}$ Joseph B. Treaster, "New Haiti Chiefs Charm 3 Backers of Democracy," New York Times, September $28,1988$.

${ }^{867}$ Ibid.

${ }^{868}$ Robert Pear, "A Surprising Chance for Democracy in Haiti," New York Times, October 9, 1988.
} 
government would not survive, General Avril retired Colonel Paul with the understanding that he would not be extradited to the United States to stand trial. ${ }^{869}$ The removal of Paul was viewed by the U.S. as an encouraging move in the right direction. ${ }^{870}$ A month after being dismissed, Colonel Paul would die from a heart attack many believed was induced by poisoning. ${ }^{871}$

While U.S. officials were adamant that there needed to be "concrete improvements on human rights and progress toward democracy before the money start[ed] flowing again," 872 the Reagan Administration would work around a Congressional ban to make available $\$ 30$ million. This represented a major shift in policy toward the Haitian government. Though some foreign aid specialists criticized the U.S. release of aid money, considering that Avril had "delivered little on his promises," ${ }^{873} \mathrm{a}$ number of prominent Haitians saw "no competent alternative and fear[ed] that if his Government falls, it might be replaced by a committee of noncommissioned officers like those who took credit for the coup in September." ${ }^{874}$

As Avril maneuvered to increase the legitimacy of his transitional government in the eyes of the international community, the popular organizations increasingly denounced dialogue with what they viewed as a continuation of Duvalierism without

\footnotetext{
${ }^{869}$ Ibid.

${ }^{870}$ Joseph B. Treaster, "Haitians Fear Violence After Colonel's Ouster," New York Times, October 2, 1988.

871 "Haitian Officer Charged by U.S. is Reported Dead," New York Times, November 7, 1988.

872 Treaster, "Haitians Fear Violence," New York Times, October 2, 1988.

${ }^{873}$ Joseph B. Treaster, "U.S. Mellowing Toward Haiti, Releases Some Aid," New York Times, November 20, 1988.

${ }^{874}$ Joseph B. Treaster, "Haiti's New Chief Fostering Doubts," New York Times, December 6, 1988.
} 
Duvalier. For many Haitians, nothing had changed. The officers removed from the military during the September 17 movement remained a threat to the population, considering the Avril government's failure to detain and disarm them. This was similarly true of the hundreds and perhaps thousands of macoutes spread across the country. Most disturbing was the failure of the Avril government to take action against Claude Raymond, a former Duvalierist chief of staff of the Army and prominent macoutes, who many believed was responsible for the November 29 election-day massacre. "The limited nature of the purge of tontons macoutes" and the "lack of sanctions against the dismissed officers" raised a number of questions regarding the intentions of the Avril government. ${ }^{875}$

Though Namphy was removed from power, the National Alliance of People's Organizations (ANOP) had not forgotten that the population once mobilized against the likes Avril when he was a member of the CNG. So it rejected the notion of dialogue with the current regime. ${ }^{876}$ In remembrance of the murders carried out by the military regimes in Martissant, at Fort Dimanche, and on November 29, ANOP continued setting up vigilance brigades so the citizenry could continue defending itself from what it believed was yet another criminal government. ${ }^{877}$ Similarly, the Federation of Brigades of Port-auPrince (Federasyon Brigad Nan Potoprens) denounced the Avril government and the members of the "responsible opposition" who were already planning the path towards

\footnotetext{
${ }^{875}$ Joseph B. Treaster, "Many in Haiti Wonder Who is Really in Charge," New York Times, September 25, 1988.

876 "ANOP Rejects Dialogue Offer," Port-au-Prince Radio Soleil Network [English Translation], September 19, 1988, Foreign Broadcast Information Service (FBIS) Daily Reports, Latin America, September 20, 1988.

${ }^{877}$ Ibid.
} 
elections without first seeking justice. In a press release, they declared:

We, whose brothers and mothers died in front of the polling stations on Ruelle Vaillant and in the Artibonite; we whose husbands, sisters, and brothers had their guts spilled, or were barbecued, or shot dead at St. Jean Bosco Church, declare that not until we can feel the desire of the government in power to give us justice, not until it sets public action in motion against all the criminals, will we follow the path outlined for us, with all the traps it contains. This is to say that these brigades do not at all believe in this business of elections for the time being--not until there has been a thorough cleanup in the way things are being run, not until there has been a trial, and not until all the victimized people have been given justice. ${ }^{878}$

Aristide, in his first major sermon following the September 11 attack, would echo these same sentiments. He demanded to know why the criminals responsible for the murderers at Fort Dimanche, at Ruelle Vaillant, at St. Jean Bosco, in Jean-Rabel, in Labadie, of Louis Eugene Athis, of Yves Volel, of Lafontant Joseph, and countless others, were not being sought out by the Avril government, disarmed, arrested, and tried in the people's courts. He warned that if steps were not taken to administer justice immediately, before elections, the same forces of the past would return, only to massacre the people worse than before. ${ }^{879}$

These warnings would come to seem prescient as Avril began systematically weakening the influence of the officers and soldiers most active in the September 17 Movement, eventually plotting to remove them from the military entirely. Though Avril and Hébreux initially shared an office and always appeared together, many doubted that

\footnotetext{
878 "'Brigades' Group Seeks Justice Before Elections," Port-au-Prince Radio Soleil Network [English Translation], September 29, 1988, Foreign Broadcast Information Service (FBIS) Daily Reports, Latin America, October 3, 1988.

879 "Father Aristide Message Urges 'Cleanup,"' Port-au-Prince Radio Soleil Network [English Translation], October 5, 1988, Foreign Broadcast Information Service (FBIS) Daily Reports, Latin America, October 6, 1988.
} 
that the lower officers, who came to form a 30-member liaison committee, had much authority. ${ }^{880}$ As Avril consolidated his hold over the military, reestablishing discipline and the chain-of-command, it became increasingly clear that Hébreux's role was merely symbolic. Some believed Avril was simply "using the lower-ranking soldiers as a buffer in carrying out his own policies," passing off decisions protested by the opposition as what the "little soldiers want[ed]." ${ }^{881}$ This became more apparent as his government was increasingly lauded in the U.S. press as "a surprising chance for democracy." ${ }^{882}$ While Haiti's chief delegate at the United Nations declared that the Avril government was a reflection of "the people's commitment to irreversible democracy," ${ }^{883}$ the Ti Soldats who sparked the mobilizations of September 17 uprisings were protesting that they were the "victims of a crooked domination..." ${ }^{884}$ While they wanted to appoint representatives of the popular organizations to the ministries, to ensure that the interests of the people were defended, the military government ensured the opposite. "Macoutes were removed and other macoutes were appointed in their place." 885

Avril's first overt challenge to the new order the Ti Soldats and the grassroots organizations sought to create would be to declare the People's Court in Côtes-de-Fer

\footnotetext{
${ }^{880}$ Joseph B. Treaster, "The General and the Sergeant: Confreres in Haiti," New York Times, October 3, 1988.

${ }^{881}$ Ibid.

${ }^{882}$ Robert Pear, "A Surprising Chance for Democracy in Haiti," New York Times, October 9, 1988.

${ }^{883}$ Ibid.

884 "CATH Cites 'Pilots' to Derail 17 Sep Movement," Port-au-Prince Radio Soleil Network [English Translation], October 10, 1988, Foreign Broadcast Information Service (FBIS) Daily Reports, Latin America, October 12, 1988.

${ }^{885}$ Ibid.
} 
illegal. Subsequently, the Avril government would send soldiers in battle gear with heavy weapons to disband the outdoor court, installing a new commanding officer to replace the one chosen by the Ti Soldats and the local population in the aftermath of September 17. ${ }^{886}$ Avril and his counterparts would later use a coup attempt in October by rival macoutes forces within the military as an opportunity to remove the soldiers who participated in the September 17 uprising against Duvalierism from the military entirely. Nearly a dozen of the noncommissioned officers who put him into power would be jailed, and the 30-member liaison committee subsequently disbanded. Months later they would be released without explanation. Rather than a response to the coup attempt, the arrests were merely part of a broader agenda to consolidate his power. ${ }^{887}$ As the Ti Soldats were sufficiently bowed, Avril began targeting elements of the opposition, arresting Rockefeller Guerre and Sylvan Jolibois for a small explosion during Carnival, likely carried out by macoutes, only to release them days later, again without explanation. ${ }^{88}$

Despite acknowledgement that Avril's record on human rights was hampered by arbitrary arrests, the U.S. government argued that his responses to protests were restrained, involving tear gas and clubs, but no deaths. The argument for tolerating Avril's abuses was that he had to "move slowly so as not to provoke the thugs and power brokers from the Duvalier days." ${ }^{889}$ Similar claims would come from amongst the

\footnotetext{
886 "Soldiers Break Up Cotes de Fer People's Court," Port-au-Prince Radio Soleil Network [English Translation], October 7, 1988, Foreign Broadcast Information Service (FBIS) Daily Reports, Latin America, October 11, 1988. 
"responsible opposition." While some viewed his televised discussions with the opposition regarding the creation of an electoral council as "evidence of a desire to delay elections," a number of centrist politicians declared that it was "not important whether General Avril [was] trustworthy or personally believe[d] in democracy." Rather, what mattered to them was that he controlled the army, was open to dialogue with the opposition, and had no alternative but to move towards elections if U.S. aid was to be resumed. ${ }^{890}$ After surviving a mutiny among two of the Haitian Armed Forces' main units, the Dessalines Battalion and Leopards Corps, Congress would approve a limited restoration of aid, and begin discussing the possibility of resuming a "limited amount of military assistance...to permit the Haitian armed forces to maintain public order." 891

While some viewed the armed confrontation with the mutinous military units as deriving from Avril's failure to move against Duvalierists as vigorously as was demanded by the Ti Soldats and the grassroots organizations at the outset, ${ }^{892}$ others contended that the Avril government was as corrupt and rapacious as those who sought to displace it. According to many in the popular movement, the Avril government's "house cleaning" of the military was mostly directed towards his rivals rather than those who were known to be involved in criminal activity. As he removed his rivals from the military, those loyal to him were placed in a more secure position to profit from cocaine trafficking, smuggling of imported goods, and general theft and extortion. ${ }^{893}$ While the Avril government failed

\footnotetext{
${ }^{890}$ Ibid.

${ }^{891}$ Joseph B. Treaster, "Rebellious Troops in Haiti Say They are Ready to Negotiate," New York Times, April 10, 1989.

${ }^{892}$ Howard W. French, "Haiti's Hope is Hostage to Its Army," New York Times, April 9, 1989.

${ }^{893}$ Lucy Komisar, "A New Duvalier in Haiti," New York Times, April 22, 1989.
} 
to address the escalating insecurity in Port-au-Prince, characterized by frequent robberies, rapes, and murders, it had been active in mobilizing the military and police to crack down on the vigilance brigades established to protect poor communities from macoutes violence. In the rural areas, government forces actively harassed and detained members of peasant and youth organizations critical of the Avril government. ${ }^{894}$

Even claims by the State Department that the Avril government was making strides towards democracy, at least at a Constitutional level, would also be challenged. While General Avril reinstated the Constitution of 1987, one of the conditions for aid renewal, this was not without some critical modifications. He specifically excluded 38 articles from the original Constitution that limited presidential power over the legislature, the high court, and the armed forces. ${ }^{895}$ Nevertheless, the U.S. Ambassador to Haiti, Clinton McKinley, a good friend of General Avril, continued "working non-stop to convince Congress that [though] all the necessary conditions for elections in Haiti [were] not yet present...all efforts [were] really being made so that there [could] one day be elections...[so that] aid for fiscal year 1989-90...[would] be unblocked."896

According to CATH's Executive Secretary Jean Auguste Mesyeux, the "business of free elections in Haiti [was] a dream. We are not against there being elections. However, we say that the political climate is clearly unfavorable for elections. There are a

\footnotetext{
${ }^{894}$ Howard W. French, "Rights Groups Fault General for Haiti Abuses," New York Times, September 17, 1989.

${ }^{895}$ Lucy Komisar, "A New Duvalier in Haiti?" New York Times, April 22, 1989.

896 "Press Comments on U.S. Company Contract, Aid," Port-au-Prince Radio Soleil Network [English Translation], August 14, 1989, Foreign Broadcast Information Service (FBIS) Daily Reports, Latin America, August 22, 1989.
} 
number of signs that clearly indicate that we are heading straight for another 29

November," ${ }^{897}$ and thus another election-day massacre. For the Comme Il Faut

Cooperation Group, "the solution to the Haitian people's problems [did] not lie in rigged elections. Only a people's government can satisfy the Haitian people's demands, such as the demands for creole pigs, health care, education, justice, a decline in the cost of living, and security." 898

\section{DIALOGUE RUNS ITS COURSE}

As the Avril government gained greater legitimacy internationally, it became more and more apparent that it sought to commit Haiti to a number of internationally binding agreements before a democratically elected government could come to power. This would lead to increased confrontation with both the "responsible opposition" and the grassroots organizations. One of the first of such actions resisted by the opposition was the Avril Government's contract with the American company Monte Christi Corporation S.A. setting up a free trade industrial zone in the northeast of the country in an area known as Plantation Dauphin near Fort Liberte. According to Finance Minister Leonce Thelusma, the Haitian Government would own 30 percent of the project through the leased land, while Haitian businessmen and the Monte Christi Corporation would own the remaining 70 percent. ${ }^{899}$ Almost immediately the People's National Assembly (APN)

\footnotetext{
897 "CATH Grants 26 Jul Press Conference," Port-au-Prince Radio Haiti-Inter [English Translation], July 27, 1989, Foreign Broadcast Information Service (FBIS) Daily Reports, Latin America, July 31, 1989.

898 "Group Marks Anniversary; Splits from KID," Port-au-Prince Radio Haiti-Inter [English Translation], August 1, 1989, Foreign Broadcast Information Service (FBIS) Daily Reports, Latin America, August 3, 1989.

899 "Contract Signed to Develop Free Zone," Port-au-Prince Radio Haiti-Inter [English Translation], July
} 
noted that an unelected provisional government was signing a contract with a foreign company without even putting the matter up for public debate, nor had it made the contract public so everyone could see what was stipulated in it. The APN would declare that "General Avril's de facto government [was] not empowered by the Constitution to make long-term commitments in the name of the Haitian Government" ${ }^{900}$ PUCH declared that since Avril set up an electoral council to organize elections, he acknowledged that his government was provisional, and thus had "no mandate to negotiate any contract that constitutes a commitment that will affect the nation's economic and political future." 901 Conacom contended that "in the absence of a parliament, the de facto government, acting as both executive and legislative branches of government, [was] taking measures which...[could] have profound consequences on the nation's future." ${ }^{902}$ The Finance Minister would retort that the government did not stop existing just because it was provisional. That since the legislature did not exist, if he waited for them, when would the country be able to function? ${ }^{903}$

Confrontation with the Avril government would escalate further as the opposition rejected efforts by his government to push through structural adjustment reforms.

27, 1989, Foreign Broadcast Information Service (FBIS) Daily Reports, Latin America, July 31, 1989.

900 "APN Protests Contract," Port-au-Prince Radio Metropole [English Translation], July 28, 1989, Foreign Broadcast Information Service (FBIS) Daily Reports, Latin America, July 31, 1989.

901 "PUCH Denounces Zone Contract," Port-au-Prince Radio Nationale [English Translation], July 28, 1989, Foreign Broadcast Information Service (FBIS) Daily Reports, Latin America, July 31, 1989.

902 "Conacom Responds to Economic Measures," Port-au-Prince Radio Metropole [English Translation], August 3, 1989, Foreign Broadcast Information Service (FBIS) Daily Reports, Latin America, August 4, 1989.

903 "Finance Minister Comments on Free Zone Project," Port-au-Prince Radio Soleil Network [English Translation], August 2, 1989, Foreign Broadcast Information Service (FBIS) Daily Reports, Latin America, August 4, 1989. 
According to Max Bourjolly of PUCH, "one of the IMF premises for applying its measures is that Haiti lives beyond its means. This is completely absurd in a country where 80 percent of the population lives on the threshold of poverty." ${ }^{904}$ Bourjolly believed that it was not possible to apply the IMF's austerity measures and transition to democracy simultaneously. At a time when the people were close to being able to choose their own government, one obligated to carry out policies to their benefit, the IMF was locking the Haitian government in a position where it would be forced to reduce its role in providing services such as education and healthcare, which were never provided to begin with. "The masses would be the principal victims of such a situation. They would not be able to demand their rights."

According to the Coordinating Body of People's Organizations of the Artibonite (Copal), as money was siphoned out of various government enterprises, leaving them in a deficit, the country's foreign debt went unpaid. Now, the IMF and the Americans were asking the Haitian Government "to apply a policy of austerity to pay the foreign debt so millions [could] continue to pour into Swiss banks," rather than to serve the population as intended. ${ }^{906}$ The National Alliance of People's Organizations (ANOP) rejected the notion that the poor and working class should be made to repay debts that they did not incur. ${ }^{907}$

\footnotetext{
904 "PUCH Predicts Upheaval from IMF Measures," Port-au-Prince Radio Metropole [English Translation], August 24, 1989, Foreign Broadcast Information Service (FBIS) Daily Reports, Latin America, August 30, 1989.

905 Ibid.

906 "Repression, U.S. Dollar Discussed in Artibonite," Port-au-Prince Radio Soleil Network [English Translation], September 11, 1989, Foreign Broadcast Information Service (FBIS) Daily Reports, Latin America, September 13, 1989.

907 "ANOP Holds News Conference on Cost of Living," Port-au-Prince Radio Soleil Network [English Translation], September 14, 1989, Foreign Broadcast Information Service (FBIS) Daily Reports, Latin
} 
To carry out such policies, "there would [have to] be a strong-man government in place," ${ }^{908}$ leaving no room for any real democracy to exist.

Some juxtaposed the government's call for austerity with the granting of a free trade zone to "American, Dominican, and other capitalists, who won't have to pay a red cent in taxes..."909 Rather than forcing the large merchants and industrialists to fulfill their tax obligations, the government was going to tax the small Haitian vendors, drivers, and other working class citizens to death, ${ }^{910}$ while eviscerating their purchasing power by devaluing the Haitian gourde, further increasing the cost of cooking oil, flour, sugar, soap, gas, cement, tin sheeting, and other goods that the poor and working class depend on. The MPP called on the government to "issue a decree abolishing the taxes the peasants pay to lease government lands, which are completely eroded. Obtain the money, instead, from the salaries being paid to bigshots and from the profits the bourgeois make at the expense of the Haitian people, whether it be in commerce, factories, banks, or elsewhere." 911 The Haitian Chamber of Commerce and Industry similarly criticized the government for "forcing the have-nots to squeeze blood from a turnip." Instead, they called on the government to focus on the fact that 60 percent of the budgets of Haiti's state-owned industries, such as the Minoterie (the national flour mill), Ciment d'Haiti

\footnotetext{
America, September 19, 1989.

908 "PUCH Predicts Upheaval from IMF Measures," Port-au-Prince Radio Metropole, August 24, 1989.

909 "PUCH Denounces Zone Contract," Port-au-Prince Radio Nationale, July 28, 1989.

${ }^{910}$ Ibid.

911 "Peasant Movement Assesses Haitian Situation," Port-au-Prince Radio Soleil Network [English Translation], September 20, 1989, Foreign Broadcast Information Service (FBIS) Daily Reports, Latin America, September 21, 1989.
} 
(Haiti's cement plant), and Teleco (the national telephone company), go to only 20 percent of employees in the form of salaries. Rather than serve as sinecures for the politically connected, the Chamber viewed the reform of these state-owned companies, as well as efforts to end the contraband trade that costs the country $\$ 60$ million a year in unpaid customs duties, ${ }^{912}$ as the only viable ways to move Haiti towards development, rejecting the IMF's austerity.

Seventeen unions, political parties, and grassroots organizations from across the ideological spectrum would come together to demand that the Avril government annul the economic agreements made with the IMF at the expense of the Haitian people. They would call on the population to mobilize on September 18 for a 15 -minute work stoppage that day at noon pou bat teneb, to beat on their pots and pans and honk their car horns, across all the neighborhoods, all the towns, and all the rural sections of Haiti, as a warning to the Avril government. Should the government fail to adhere to the will of the population, they would call for a general strike. ${ }^{913}$ The government reacted to this threat by arresting Max Bourjolly, one of the leaders of PUCH, along with two members of the Federation of Neighborhood Committees and Associations. Attacks would also be launched against the headquarters of the popular organization Comme Il Faut, affiliated with KID. ${ }^{914}$

\footnotetext{
912 "General Strike Paralyzes Port-au-Prince," Port-au-Prince Radio Metropole [English Translation], September 27, 1989, Foreign Broadcast Information Service (FBIS) Daily Reports, Latin America, September 29, 1989.

913 "Organizations Scheduled to Protest Inflation," Port-au-Prince Radio Soleil Network [English Translation], September 15, 1989, Foreign Broadcast Information Service (FBIS) Daily Reports, Latin America, September 18, 1989.

914 "Democratic Unity Denounces Actions," Port-au-Prince Radio Soleil Network [English Translation], September 18, 1989, Foreign Broadcast Information Service (FBIS) Daily Reports, Latin America,
} 
Avril in an interview would state that it was too late to dissolve the agreement, and that "faced with imminent economic catastrophe, the government had its back to the wall and was forced to take measures to redress the situation." ${ }^{915}$ Avril argued that "once an agreement [had] been singed...it [was] signed for good. So, [could] we now go and renege? [Could] we now tell the IMF that we [were] taking back our signature? That is unheard of...We have already signed and already received the money." 916 Instead, he reproached the leaders of the strike, saying that they should have sought the path of dialogue rather than pursue a path that was not going to lead to anything. Maurepas Auguste of the Movement for Democratic Unity (MDU) would counter this statement declaring, "rather it is you, as chief of state, who should have engaged in dialogue with [the] people before taking your measures!" 917

As the number of organizations in support of a general strike increased to over 30 , and the strike date was set for September 27, 1989, the Ministry of Information and Coordination announced that a draft electoral calendar had been submitted by the Provisional Electoral Council (CEP) to the Avril government, setting the dates for local elections in April 1990, for legislative elections in July, runoff legislative elections in August, and presidential elections in October, with a possible runoff set for November September 20, 1989.

915 "Avril Interview on Election, Strike Plans," Port-au-Prince Radio Metropole [English Translation], September 26, 1989, Foreign Broadcast Information Service (FBIS) Daily Reports, Latin America, September 29, 1989.

\footnotetext{
916 "Avril Discusses 27 September Strike Demands," Port-au-Prince Radio Soleil Network [English Translation], September 29, 1989, Foreign Broadcast Information Service (FBIS) Daily Reports, Latin America, October 3, 1989.

917 "Politicians on Strike, 'Foreign Interference,"' Port-au-Prince Radio Metropole [English Translation], September 28, 1989, Foreign Broadcast Information Service (FBIS) Daily Reports, Latin America, October 2, 1989.
} 
$1990 .{ }^{918}$ While the Avril government declared "the publication of this calendar...an important step in the realization of the democratic process,"919 and the State Department announced that it was encouraged by this development, ${ }^{920} \mathrm{PUCH}$ viewed the release of the election calendar at this time as simply a government attempt to dampen the resolve of the organizations planning the September 27 strike, perhaps enticing elements of the "responsible opposition" to return to a more conciliatory position. ${ }^{921}$

A closer look at the electoral calendar itself highlighted what the general secretary of PUCH, Rene Theodore, believed was an intent to fragment the voting process, possibly opening the door to massive levels of fraud considering Haiti's lack of capacity. Conacom, which recently became an official political party, viewed the election calendar as particularly convoluted. According to the new party's Secretary General, Victor Benoit, the calendar not only allowed the provisional government to remain in office for another 18 months, despite widespread disapproval of its actions, but it asked the population to vote 8 different times, which was likely to demobilize it. ${ }^{922}$

On September 27, a general strike would completely paralyze Port-au-Prince and much of the provinces. Public transportation was nonexistent throughout the country, factories were shut down, and even flights were impacted. The organizers of the

\footnotetext{
918 "Presidential Election Planned for Oct 90," Port-au-Prince Radio Nationale [English Translation], September 25, 1989, Foreign Broadcast Information Service (FBIS) Daily Reports, Latin America, September 26, 1989.

${ }^{919}$ Ibid.

920 "Diverse Reaction to Proposed Election Calendar," Port-au-Prince Radio Metropole [English Translation], September 26, 1989, Foreign Broadcast Information Service (FBIS) Daily Reports, Latin America, September 29, 1989.

${ }^{921}$ Ibid.

${ }^{922}$ Ibid.
} 
September 27 strike declared that they were not going to rest on the laurels of their recent success, but rather build on it. According to Evans Paul of KID, the success of the strike highlighted the people's conviction and willingness to sacrifice in order to see a change, the lack of public support for the Avril government across a broad cross-section of Haitian society, and that the people were once again beginning to mobilize despite the year or so of government repression. "We feel that it is long overdue for a small handful of people to stop making decisions for the Haitian people, to stop taking care of their own affairs at the expense of the Haitian people, to stop making decisions that are detrimental to the Haitian people and nation. ${ }^{923}$ Paul would call on those who did not take part in the strike to confront their consciences and join the people's camp. ${ }^{924}$ The group of 30something organizations would form a pressure group called the Rassemblement National (National Assemblage) to demand greater transparency in the management of public affairs and the right to maintain oversight over government decisions. ${ }^{925}$ "This was an expression of the need for Haiti to have a counter power...that even can orient the government and government decisions in the direction of the interests of the nation and the masses...Perhaps it [would] even manage to form an executive that [would] accept control and that [would] itself be capable of ensuring a truly democratic transition." ${ }^{926}$

\footnotetext{
923 "KID Praises Strike, Gives Avril Deadline," Port-au-Prince Radio Soleil Network [English Translation], September 29, 1989, Foreign Broadcast Information Service (FBIS) Daily Reports, Latin America, October 3, 1989.

${ }^{924}$ Ibid.

925 "PUCH, PDCH Leaders Issue Statements," Port-au-Prince Radio Metropole [English Translation], October 5, 1989, Foreign Broadcast Information Service (FBIS) Daily Reports, Latin America, October 11, 1989.

926 "33 Organizations Form 'Pressure Group,"' Port-au-Prince Radio Nationale [English Translation], October 5, 1989, Foreign Broadcast Information Service (FBIS) Daily Reports, Latin America, October 12,
} 
In Gonaives, protestors from the impoverished neighborhoods of Raboteau, Jubile Blanc, and Lot Bo Kanal erected burning tires across intersections and clashed with the military as they declared that they were not only mobilizing to address the high cost of living and insecurity, but to tell the general that he had "to uproot his cassava plants and move off the land...so that they can install a civilian government.".927 A similar mobilization would begin in Petit-Goave, where barricades burned and slogans across walls read, "Down with the Avril-Heubreux government" and "The revolution is going to begin." ${ }^{928}$ The National Assemblage would announce plans for a national march on November 29, in memory of those who were killed during the 1987 election-day violence, and to demand that Avril step down from power. ${ }^{929}$

A few days after calling for a popular mobilization, the Avril government would arrest three prominent figures within the National Assemblage, Jean Auguste Mesyeux of CATH, Evans Paul of the KID, and former soldier, Etienne Marino, a prominent figure within the 17 September People's Organization (OP-17). The government claimed to find a number of assault rifles, bullets, and dynamite in their homes, declaring that their objective was "to assassinate the president of the military government, eliminate all

1989.

927 "Demonstrators Seek Removal of President Avril," Port-au-Prince Radio Metropole [English Translation], October 11, 1989, Foreign Broadcast Information Service (FBIS) Daily Reports, Latin America, October 16, 1989.

928 "Military Presence Halts Petit Goave Disturbance," Port-au-Prince Radio Soleil Network [English Translation], October 16, 1989, Foreign Broadcast Information Service (FBIS) Daily Reports, Latin America, October 18, 1989.

929 "Assemblage Says Avril Must Go; March Planned," Port-au-Prince Radio Metropole [English Translation], October 31, 1989, Foreign Broadcast Information Service (FBIS) Daily Reports, Latin America, November 2, 1989. 
FADH officers, and kill certain prominent civilians, and form a popular militia." ${ }^{1930}$ The government would name a number of other individuals who were being sought after as a result of being implicated in the plot. According to Eddy Volel of the Christian Democratic Assembly (RDC), the Avril government arrested the three men "in Duvalier fashion, in order to defuse all the movements of generalized protest that are going to be." ${ }^{931}$ The arrests and beatings would lead to a two-day general strike on November 7 and $8 .{ }^{932}$

CATH Secretary General Yves Antoine Richard would declare that the strike was not simply about having the three men released, but "to rekindle the people's battle, which must not stop along the way...Even if they are released, we must continue 'Operation Sweep Them Away."'133 While Richard called on the population to reject those who would seek to shift the people's agenda away from confronting Duvalierism and macoutism towards elections, Bourjolly called for those politicians who put "themselves under the government's wing so that it [could] hold for them the kind of election it held for Manigat on 17 September" to "raise their voices loudly to condemn these acts of intimidation and terrorism that have just been committed against the

\footnotetext{
930 "Avril Assassination Plot Disclosed," Port-au-Prince Radio Soleil Network [English Translation], November 3, 1989, Foreign Broadcast Information Service (FBIS) Daily Reports, Latin America, November 6, 1989.

931 "Political Leaders React," Port-au-Prince Radio Metropole [English Translation], November 3, 1989, Foreign Broadcast Information Service (FBIS) Daily Reports, Latin America, November 6, 1989.

932 "Assemblage Calls Protest Strike," Port-au-Prince Radio Soleil Network [English Translation], November 6, 1989, Foreign Broadcast Information Service (FBIS) Daily Reports, Latin America, November 7, 1989.

933 "CATH Secretary General Cites Aims of Strike," Port-au-Prince Radio Soleil Network [English Translation], November 7, 1989, Foreign Broadcast Information Service (FBIS) Daily Reports, November $8,1989$.
} 
democratic sector, so that public opinion will not point the finger at them too, as accomplices to what [was being done here." 934

Nevertheless, the members of the CEP would declare that they were "organizing themselves so that they [could] give the Haitian people proper elections." ${ }^{935}$ They simply asked the Haitian people to trust them. This position would be supported by the National Alliance for Democracy and Progress (ANDP), which was made up of Marc Bazin's MIDH, Deajean Belizaire's MNP-28, and Serge Gilles' Panpra. While the ANDP congratulated those responsible for carrying out the two-day strike, it stated that in "all crisis situations, there are two possible paths to a solution...one based on a policy of force, and the other based on political force...ANDP feels the strategy based on political force is the proper approach, an appropriate...realistic, and reasonable approach." 936 Though this meant advocating for the legal and Constitutional rights of the three arrested men, it also meant holding free and fair democratic elections as soon as possible. For the ANDP, this was the only realistic way to move beyond the current crisis. ${ }^{937}$

The position of ANDP would stand in contrast to that of six centrist political parties $^{938}$ who would call for another 24-hour strike on November 22, declaring that "the

\footnotetext{
934 "Political Leaders React," Port-au-Prince Radio Metropole [English Translation], November 3, 1989, Foreign Broadcast Information Service (FBIS) Daily Reports, Latin America, November 6, 1989.

935 "CEP President Auguste Asks for People's Trust," Port-au-Prince Radio Nationale [English Translation], November 13, 1989, Foreign Broadcast Information Service (FBIS) Daily Reports, Latin America, November 15, 1989.

936 "Alliance Proposes Solution to Current Crisis," Port-au-Prince Radio Soleil Network [English Translation], November 10, 1989, Foreign Broadcast Information Service (FBIS) Daily Reports, Latin America, November 15, 1989.

937 Ibid.

938 The National Agricultural and Industrial Party (PAIN); the Movement for the Organization of the Country (MOP); the Haitian Christian Democratic Party (PDCH); the Union of Democratic Patriots (UDP);
} 
mobilization of the Haitian people would continue until the de facto government of Lt. Gen. Prosper Avril left power." 939 This call for dialogue became increasingly problematic as armed civilians beat and gunned down three young members of Leslie Manigat's Assembly of Progressive National Democrats (RDNP) for putting up posters calling for the return of the exiled former president. ${ }^{940}$ Pressure would be applied by the new U.S. Ambassador to Haiti, Alvin Adams, who "recalled the military government's irrevocable promise to relinquish power to a civilian government and expressed the hope that the elections would be free and honest and would take place in a climate of security." 941

In January, the conflict between the opposition and the Avril government would come to a head, sparked by Avril's unannounced 8-day state trip to Taiwan in an effort to promote greater South-South diplomacy. ${ }^{942}$ Nearly immediately, PUCH's Rene Theodore declared his disapproval of the state trip decalring that "an unpopular government like Prosper Avril's [had] no right to travel abroad in the name of the Republic." ${ }^{943}$ With that

the Mobilization for National Development (MDN); and the Christian Democratic Assembly (RDC).

939 "Political Parties Call for Further Strikes," Port-au-Prince Radio Soleil Network [English Translation], November 21, 1989, Foreign Broadcast Information Service (FBIS) Daily Reports, Latin America, November 22, 1989.

\footnotetext{
940 "Manigat Supporters Killed by 'Armed Civilians,"' Port-au-Prince Radio Soleil Network [English Translation], November 20, 1989, Foreign Broadcast Information Service (FBIS) Daily Reports, Latin America, November 22, 1989.

941 "U.S. Ambassador's Meeting Canceled," Port-au-Prince Radio Metropole [English Translation], November 28, 1989, Foreign Broadcast Information Service (FBIS) Daily Reports, Latin America, November 30, 1989.

942 "Avril, Entourage Depart for Taiwan 7 January," Port-au-Prince Radio Metropole [English Translation], January 8, 1990, Foreign Broadcast Information Service (FBIS) Daily Reports, Latin America, January 9 , 1990.

943 "PUCH Comments on Avril's Taiwan Trip," Port-au-Prince Radio Metropole [English Translation], January 9, 1990, Foreign Broadcast Information Service (FBIS) Daily Reports, Latin America, January 11, 1990.
} 
same rationale, Dr. Louis Roy, Father Antoine Adrien, and Antoine Izmery, of the Unity Committee for the Respect of the Constitution, would send a telex message to the Taiwanese Government declaring that "the Haitian people were not aware of the reason for General Avril's visit and that any agreements with him would not be binding," stifling any possible deals the government hoped to make while abroad. ${ }^{945}$

Upon his return from Taiwan on January 15, Avril declared that the political parties were not opposing the government when they took the actions they did, but rather betraying the Haitian people. ${ }^{946}$ The following week, armed civilians would begin targeting journalists critical of the regime, with the murder of Radio Cacique journalist Jean Andre Wilfrid Destin serving as the initial sign of the state's repression to come. ${ }^{947}$ The Avril government would use the murder of Colonel Andre Neptune to declare a state of siege, after which the military began arresting opposition leaders. ${ }^{948}$ "Considering the series of acts against the public order...which tend to hinder the normal functioning of the national institutions and perturb the democratic process," the Avril government would temporarily suspend a number of articles of the Constitution and declare 30 days of

\footnotetext{
${ }^{944}$ Joseph B. Treaster, "Haiti Deports Some Opposition Leaders," New York Times, January 22, 1990.

945 "President Avril Castigates Constitution Group," Port-au-Prince Radio Soleil Network [English Translation], January 16, 1990, Foreign Broadcast Information Service (FBIS) Daily Reports, Latin America, January 19, 1990.

946 "General Avril Returns from Taiwan 15 January," Port-au-Prince Radio Soleil Network [English Translation], January 16, 1990, Foreign Broadcast Information Service (FBIS) Daily Reports, Latin America, January 17, 1990.

947 "Further Harassment Suffered by Journalists," Port-au-Prince Radio Soleil Network [English Translation], January 19, 1990, Foreign Broadcast Information Service (FBIS) Daily Reports, Latin America, January 23, 1990.

948 "Opposition Leaders Detained, 'Severely Beaten,'" Paris AFP [English Translation], January 20, 1990, Foreign Broadcast Information Service (FBIS) Daily Reports, Latin America, January 22, 1990.
} 
martial law. ${ }^{949}$ The government subsequently issued a decree reinstating entry visas for Haitians, "considering that the very easy access to the national territory...favor the entry of agents of subversion. ${ }^{950}$ While many opposition leaders would be released, Max Bourjolly of PUCH, Hubert de Ronceray of MDN, Louis E. Roy of the Organization for the Defense of the Constitution, Sylvain Jolibois of the Jean-Jacques Dessalines Nationalist Sector, Michel Legros of the League for the Installation of Democracy, Gerard Emile Brun of Conacom, and Max Montreiul of the neighborhood committee of Cap Haitien would all be expelled from the country. ${ }^{951}$

The Minister of Interior and Defense would later announce that those expelled during the state of siege would have an opportunity to return for the presidential elections in October. ${ }^{952}$ Many within the opposition viewed this announcement as part of a broader strategy by the Avril government to ensure that candidates closely aligned with the regime would dominate the elections for local and municipal offices, as well as the legislature. This also made certain that "any candidate who return[ed] from exile late in the year would begin the presidential campaign with a severe handicap." 953

\footnotetext{
949 "Government Declares Martial Law for 30 Days," Port-au-Prince Radio Nationale [English Translation], January 20, 1990, Foreign Broadcast Information Service (FBIS) Daily Reports, Latin America, January 23, 1990.

950 "Decree Reinstates Entry Visas for Haitians," Port-au-Prince Radio Nationale [English Translation], January 20, 1990, Foreign Broadcast Information Service (FBIS) Daily Reports, Latin America, January 23,1990 .

951 "Communist Leader Bourjolly Expelled," Paris AFP [English Translation], January 21, 1990, Foreign Broadcast Information Service (FBIS) Daily Reports, Latin America, January 22, 1990. "Opposition Leader Brun Expelled from Country," Paris AFP [English Translation], January 22, 1990, Foreign Broadcast Information Service (FBIS) Daily Reports, Latin America, January 22, 1990.

952 "Haiti Imposes Restrictions on Radio News Broadcasts," New York Times, January 24, 1990.

${ }^{953}$ Joseph B. Treaster, "Haiti's Ruler Says He'll Lift State of Siege on Tuesday, New York Times, January 1990.
} 
State Department spokesman, Richard A. Boucher, would issue a statement announcing that General Avril's actions undermined "the confidence voters must have to participate in a credible electoral process as well as the confidence of the international community in Haiti's commitment to that process." ${ }^{154}$ While these sentiments would be echoed by Alvin P. Adams, the American Ambassador in Haiti, "he indicated, however, that the United States was holding out hope that General Avril would reverse himself" and restore "confidence in the electoral process." ${ }^{.955}$ As the U.S., France, and Canada moved to suspended current economic aid to Haiti, ${ }^{956}$ the Avril government lifted the state-of-siege. This prompted Marc Bazin and his ANDP coalition to issue a statement expressing satisfaction with Avril's pledge to hold elections this year as promised. The coalition believed that it was now time for "all true democrats" to urge the CEP to "take all useful steps to insure the regularity of the electoral process and the credibility of the results. ${ }^{1957}$ On February 7, the fourth anniversary of the fall of the Jean-Claude Duvalier regime, Avril would announce a general amnesty, releasing the four opposition politicians that were previously accused of trying to assassinate him. "In a message to the nation, Avril called for a dialogue and concerted efforts with a view to a peaceful and democratic transition..." ${ }^{958}$

\footnotetext{
${ }^{954}$ Joseph B. Treaster, "Haiti Deports Some Opposition Leaders," New York Times, January 22, 1990.

${ }^{955}$ Joseph B. Treaster, "Haiti About-Face: General 'Looking Like Dictator,'" New York Times, January 25, 1990.

${ }^{956}$ Treaster, "Haiti's Ruler Says," New York Times, January 27, 1990.

957 "Haiti Coalition Backs Leader's Election Plan," New York Times, February 3, 1990.

958 "President Avril Declares General Amnesty," Paris AFP [English Translation], February 8, 1990, Foreign Broadcast Information Service (FBIS) Daily Reports, Latin America, February 8, 1990.
} 
Rather than engage in dialogue, the population took to the streets. The National Front Against Repression declared that "the primary objective of 7 February 1986 was not to merely shuffle privileges around...but rather to put an end to such privileges." 959 Instead, it called on the Haitian people to mobilize against what it increasingly deemed "democratic posturing." 960 Joseph Manusi Pierre, secretary general of the Autonomous Organization of Haitian Workers, believed that "this business of elections [had] demobilized the masses;" that many political leaders simply were not in touch with the country's realities or the critical juncture which it was currently in. ${ }^{961}$ Breaking a long silence, Aristide would call upon "all democratic forces, all antimacoute political forces, and nondemagogic ecclesiastical forces to come together so we can nationalistically put together a lucid, cooperative assembly." 962 The growing mobilization of the grassroots organizations would lead the political parties, including the ANDP, to take an unequivocal position against the possibility of having elections under the Avril government. ${ }^{963}$ On March 10, 1990, Avril would announce his resignation, after weeks of mass anti-government demonstrations throughout the country.

\footnotetext{
959 "Cites U.S. Position," Port-au-Prince Radio Metropole [English Translation], February 7, 1990, Foreign Broadcast Information Service (FBIS) Daily Reports, Latin America, February 9, 1990.

960 Ibid.

961 "Union Leader on Divisiveness, Electioneering," Port-au-Prince Radio Soleil Network [English Translation], February 8, 1990, Foreign Broadcast Information Service (FBIS) Daily Reports, Latin America, February 12, 1990.

962 "Father Aristide Calls for General Consensus," Port-au-Prince Radio Metropole [English Translation], February 21, 1990, Foreign Broadcast Information Service (FBIS) Daily Reports, Latin America, February 21,1990 .

963 "More Reportage on 28 Feb ANDP Statement," Port-au-Prince Radio Metropole [English Translation], March 1, 1990, Foreign Broadcast Information Service (FBIS) Daily Reports, Latin America, March 5 , 1990.
} 


\section{THE PERSUIT OF POLYARCHY}

As Avril was forced out of power, the opposition would come together to form a transitional government consisting of a provisional president chosen from the Court of Cassation, and a Council of State made up of representatives from the country's principle

sectors ${ }^{964}$ to maintain public oversight over the policies of the provisional government. ${ }^{965}$

Together, the provisional president and the Council of State would "establish the

political, institutional, and administrative conditions and the security necessary for the

holding of unfettered, honest, democratic elections as soon as possible..." ${ }^{966}$ As Ertha

Pascal-Trouillot came to power as the provisional president, the "responsible opposition,"

represented by the country's 11 most prominent political parties, and an increasingly

visible center-left opposition represented by the Komité Tèt Ansanm pou Onè Respè

Konstitisyon (the Unity Committee for the Respect of the Constitution), came to form the Assemblée de Concertation (the Assembly for Concerted Action). ${ }^{967}$ As the potential for

\footnotetext{
${ }^{964}$ The Council of State would be composed of representatives of the Episcopal Conference of Haiti, the Federation of Protestant Churches, the unions, the peasants, the private sector, the education sector, the socio-professional sector, the press, the human rights organizations, the Army, and the bar.

965 "Opposition Unites Around 'Common Alternative,"' Port-au-Prince Radio Antilles Internationales [English Translation], March 5, 1990, Foreign Broadcast Information Service (FBIS) Daily Reports, Latin America, March 6, 1990.

966 "Details of Proposed Alternative to Avril Outlined," Port-au-Prince Radio Antilles Internationales [English Translation], March 8, 1990, Foreign Broadcast Information Service (FBIS) Daily Reports, Latin America, March 9, 1990.

${ }^{967}$ Dejean Belizaire's National Patriotic Movement of 28 November (MNP-28); March Bazin's Movement for the Establishment of Democracy in Haiti (MIDH); Arnold Antonin's Nationalistic and Progressive Revolutionary Party of Haiti (Panpra); Emmanuel V. Beauvais's Movement for the Organization of the Country (MOP); Victor Benoit's National Committee of the Congress of Democratic Movements (Conacom); Edouard Tardieu's Social Christian People's Party of Haiti (PPSC); Seymour Romain's Naitonal Democratic Progressive Party of Haiti (PNDPH); Walter Floril's Union of Haitian Constitutionalists (UCH); Sylvio Claude's Haitian Christian Democratic Party (PDCH); Rene Theodore's Unified Party of Haitian Communists (PUCH); and Leroy Antoine's Mobilizaiton for National Development (MDN).
} 
free and fair elections increasingly became a reality, the center-left and center-right within the Assembly for Concerted Action began positioning themselves to shape an increasingly likely post-Duvalierist democratic Haiti. According to commentary from the Cuban media, the United States was still searching for "its dream figure, that is, someone to take over the reins of the island who will covertly follow U.S. orders but at the same time, of course, have a convincing enough image to avoid great social upheavals as far as possible." ${ }^{168}$ Many believed that Marc Bazin of the National Alliance for Democracy and Progress (ANDP) coalition was that figure.

Bazin, like Manigat before him, had the right pedigree for the presidency according to the various domestic and international power brokers concerned with Haiti's democratic transition. Louis Bazin, his father, served as a Senator from the Artibonite Department. Bazin himself studied law, economics, and sociology in Port-au-Prince, before attending the Solvay Institute of Sociology in Brussels, Belgium. ${ }^{969}$ In 1982, the Reagan Administration and the World Bank would insist that the Jean-Claude Duvalier government name Bazin, a World Bank development economist at the time, Minister of Finance in order to administer a number of reforms demanded by both so Haiti could continue receiving aid. ${ }^{970}$ Forced into exile after only six months in the position due to his aggressiveness in attempting to clean up the country's finances, upon his return after the

\footnotetext{
968 "Havana Says U.S. 'Deeply Involved' in Haiti," Havana Radio Rebelde Network [English Translation], March 14, 1990, Foreign Broadcast Information Service (FBIS) Daily Reports, Latin America, march 15, 1990.

${ }^{969}$ Phil Davison, "Marc Louis Bazin: Former Haitian Prime Minister and World Bank Economist," Independent, July 29, 2010.

${ }^{970}$ Stephan Haggard, "The Politics of Adjustment: Lessons From the IMF's Extended Fund Facility," International Organization 39, no. 3 (Summer 1985): 515.
} 
fall of the Jean-Claude regime in 1986, Bazin would be described as "the most able aspirant for supreme executive office" whose "advent would be welcomed by Washington." 971

More importantly, at this critical political juncture, Bazin rejected the population's calls for justice before elections, declaring that "antimacoutism" could not "constitute a government platform.."172 Since Duvalierists were Haitians as well, he could "under no circumstances be the president of only a part of the Haitians," and thus could not support what he called "returning to the past to settle old scores." ${ }^{973}$ Instead, he believed that the way forward was to move towards polyarchy. According to Bazin, the transition would take place in two stages. "The first stage would be the election itself, which would allow the Haitian people to express their preference for this or that platform. In the second stage, the government elected on the basis of the choice made by the population can open itself up to other political families for a government of national unity based on a minimal common program..."${ }^{974}$ The National Endowment for Democracy and the State Department's Office of Democratic Initiatives would spend over \$12 million preparing for the 1990 elections, with a proportion of this going towards the Bazin candidacy. ${ }^{975}$

\footnotetext{
${ }^{971}$ Graham Norton, "Review: The Haiti File," The World Today 42, no. 6 (June 1986), 108.

972 "MIDH's Bazin Interviewed by Government Paper," Port-au-Prince Radio Metropole [English Translation], April 9, 1990, Foreign Broadcast Information Service (FBIS) Daily Reports, Latin America, April 10, 1990.

${ }^{973}$ Ibid.

${ }^{974}$ Ibid.

${ }^{975}$ Clifford E. Griffin, "Haiti's Democratic Challenge," Third World Quarterly 13, No. 4 (1992), 669.
} 
In spite of Bazin's popularity with the U.S. and the international community, the population pursued its own agenda. The union federations ${ }^{976}$ called for a complete "change in the Haitian Government's traditional structures. Otherwise, they say, as much will have been accomplished as if one had washed one's hands and then wiped them on the dusty ground to dry them..."1977 They believed that the Council of State, an institution that emerged out of the popular mobilization against Avril's military dictatorship, should be made a stronger institution vis-à-vis the executive, which represented remnants of Duvalierist regimes past. "The first objective [was] to strengthen the Council of State, so that it can become the real, organized expression of the Haitian people's basic demands within the government," ${ }^{178}$ and thus force the provisional president to carry out its will.

The tensions that would emerge between the Trouillot government and the Council of State would come from its unwillingness to allow it to perform its oversight function, appointing ministers and attempting to make long-term economic agreements without the Council's approval. Tensions also revolved around the Trouillot government's failure to take action against macoutes and elements of the military that were committing crimes against the population. Father Yvon Massac called on the government to "order the Army to pursue them everywhere in Haiti," declaring that "this cleanup [was] part of the preparation for elections that the new provisional government [had] been given the

\footnotetext{
${ }^{976}$ The Autonomous Organization of Haitian Workers (CATH); the National Confederation of Haitian Instructors (CNEH); the Confederation of Haitian Workers (CTH); the Federation of Workers Trade Unions (FOS); the General and Independent Organization of Haitian Workers (OGITH); and the SEEH.

977 "Union Federations Call for Changes in Government," Port-au-Prince Radio Soleil Network [English Translation], March 15, 1990, Foreign Broadcast Information Service (FBIS) Daily Reports, Latin

America, March 20, 1990.

${ }^{978}$ Ibid.
} 
mission of holding..." ${ }^{179}$ After dismissals of a number of soldiers close to the Avril regime, former Presidential Guard soldier who headed the 17 September People's Organization, Frantz Patrick Beauchard, called on the government to not only fire these officers, but to arrest, jail, and try them. ${ }^{980}$ According to Aristide, the government had two choices regarding the threat of violence against the population that continued to exist, "either it chooses the Haitian people's path, that is, arrests and brings to trial the criminals...to provide security for the Haitian people---or it chooses the path of the macoutes, that is, talking politically about reconciliation without at the same time evoking justice to make it a reality."1981

As former Namphy acolyte, Williams Regala, and notorious macoute, Roger Lafontant, were allowed to return to Haiti without any resistance from the Haitian military or police, many within the opposition feared that the Duvalierists were preparing to orchestrate another election-day massacre. A "spate of unpunished killings and armed robberies in the capital...reminded many of the months of violence and intimidation by opponents of democratic change that preceded the 1987 elections.." ${ }^{982}$ This also created a greater rift among the political parties as the center-right parties (PDCH, MDN, MOP, Panpra, the MNP-28, and the MIDH) rejected an ultimatum given to Trouillot by the

\footnotetext{
979 "Priest Wants Strong Measures Against Macoutes," Port-au-Prince Radio Soleil Network [English Translation], March 22, 1990, Foreign Broadcast Information Service (FBIS) Daily Reports, Latin America, March 23, 1990.

980 "FADH Dismisses 7; Security Situation Viewed," Port-au-Prince Radio Soleil Network [English Translation], March 21, 1990, Foreign Broadcast Information Service (FBIS) Daily Reports, Latin America, March 22, 1990.

981 "Part 1 of Aristide Interview of Current Juncture," Port-au-Prince Radio Metropole [English Translation], April 2, 1990, Foreign Broadcast Information Service (FBIS) Daily Reports, Latin America, April 4, 1990.

${ }^{982}$ Howard W. French, "Haiti, Easing Uncertainty, Plans Elections Dec. 16," New York Times, September 30, 1990.
} 
center-left parties, demanding her government take action against the Duvalierists or be replaced by someone chosen by the State Council.

Once Lafontant announced his candidacy for president, declaring himself the "leader of the national reconciliation," the newly formed center-left coalition, the Fron Nasyonal Pou Chanjman ak Demokrasi (the National Front for Change and Democracy FNCD), ${ }^{983}$ would recruit Aristide to run for the presidency, in hopes of mobilizing the population against efforts by the Duvalierists to retake power. All the same, Aristide's candidacy went beyond preventing Lafontant from coming to power. For the center-left parties of the FNCD, it was also about finding a candidate that could galvanize the grassroots behind participation in the elections in a way that their previous choice, Victor Benoit, could not. The FNCD's hope was that Aristide could bridge the divide that had emerged between the center-left parties and the grassroots organizations that grew as a result of the former's participation and support for the failed November 1987 elections. Their fear was that a low-turn out election would likely benefit the heavily financed campaign of conservative candidate Marc Bazin and his ANDP coalition.

For Aristide, participation in the 1990 elections was a significant departure from his previous position of justice before elections. Prior to his entry into the race, the grassroots peasants organizations, popular organizations, neighborhood committees, and vigilance brigades sought to create a common agenda to organize against elections not directed by the interests of the people. Groups like Tet Kole argued that the majority of the population was being ignored, both by the traditional political parties, and by the

\footnotetext{
983 "Several Parties Form New Political Front," Port-au-Prince Radio Soleil Network [English Translation], June 15, 1990, Foreign Broadcast Information Service (FBIS) Daily Reports, Latin America, June 20, 1990.
} 
international community. They rejected being dragged into elections which existed to further the interests of others and not their own. They viewed the democracy being clamored for by the Haitian elite and the international community as a democracy that goes against the interests of the people, a democracy where the people have no voice. Tet Kole called on the poor masses to organize themselves across Haitian society, to establish true popular organizations that they controled in order to push for their own interests, while also calling for a single course of action guided by the Haitian people's demands for a people's alternative.

Aristide explained that he decided to take part in the 1990 elections, unlike elections of the recent past, because he felt that the likelihood of these elections being truly free and fair was much greater. The international context seemed ripe for Haiti's democratic transition. Most countries in Latin America and the Caribbean had made the transition from military rule to elected civilian governments. The leftist Sandinista government in Nicaragua peacefully transferred power to the opposition after supposed free and fair elections in February 1990. Also, the end of the Cold War and emergence of democratically elected governments throughout Eastern Europe also created a context where the international community would likely support elections, even the election of a leftist candidate. The Haitian military itself was now headed by Hérard Abraham, who seemed uninterested in politics, and had given up power to Ertha Pascale-Trouillot only 72 hours after Avril had stepped down.

While fundamentally rejecting the notion that elections could be a panacea for Haiti's problems, Aristide saw an opportunity for the popular movement to divert the elections towards their demands with a unified agenda represented by his candidacy as 
"the people's alternative." According to Aristide, the people wanted Duvalierists to be excluded from government office, and prosecuted for committing crimes against the people. He believed that these objectives would have to be accomplished if any of the other provisions in the constitution were to ever be seriously adhered to. For Aristide, the only way elections would be able to accomplish the people's will, was if they were directed by the mass mobilization of the population, just as the removal of Jean-Claude Duvalier was accomplished in $1986 .{ }^{984}$ Aristide's entry into the presidential race would fundamentally strengthen the position of the center-left FNCD coalition in relation to Marc Bazin's center-right ANDP coalition, by wedding the momentum of grassroots mobilization for popular democracy to the election process.

As Aristide's entry into the presidential race lead to $80 \%$ of Haiti's eligible citizens registering to vote, ${ }^{985}$ former Roman Catholic priest and human rights leader, Jean-Claude Bajeux, declared that no one knew "how Aristide conceive[d] the presidency,"1986 something he viewed as particularly dangerous. Others thought that since Aristide had entered the presidential race rather late, and without a formally structured political party, even if he won the presidency, the opposition would control the legislature, thus "assuring a system of checks and balances and a novel air of democratic

\footnotetext{
984 "Father Aristide Holds News Conference," Port-au-Prince Radio Metropole [English Translation], September 7, 1990, Foreign Broadcast Information Service (FBIS) Daily Reports, Latin America, September 11, 1990. "Father Aristide Urges Unity During Elections," Port-au-Prince Radio Haiti-Inter [English Translation], Foreign Broadcast Information Service (FBIS) Daily Reports, Latin America, October 12, 1990. "Aristide Outlines Campaign Strategy, Objectives," Havana Tele Rebelde Network [English Translation], October 24, 1990, Foreign Broadcast Information Service (FBIS) Daily Reports, Latin America, October 25, 1990.

${ }^{985}$ Howard W. French, "A Duvalier Ally and a Foe Seek Election in Haiti, Raising Fears of Violence," New York Times, November 5, 1990.

${ }^{986}$ Howard W. French, "Front-Running Priest a Shock to Haiti, New York Times, December 13, 1990.
} 
debate." ${ }^{987}$ As it was declared that Aristide won the presidential elections with $67 \%$ of the vote, and the opposition feared that the FNCD would similarly dominate the legislative elections, Louis Dejoie, who received less than $9 \%$ of the votes, argued that "many people [were] disillusioned that this could represent the elimination of political parties in Haiti." ${ }^{988}$ Though Aristide was popularly elected in one of the country's few free and fair elections in its history, Dejoie contended that the Haitian population's lack of experience with a functioning democracy impeded their ability to fully "grasp the importance of the interplay of parties and institutions like the National Assembly." 989

Other members of the "responsible opposition" increasingly expressed their concern that without a strong opposition, the Constitution, the rule of law, and the very essence of the country's new democracy would suffer. ${ }^{990}$ François Benoit of Bazin's ANDP, would make the argument that no group could govern the country alone, and therefore "the best thing for Haitian democracy would be for Aristide to choose a Prime Minister from the opposition, even if he emerge[d] with a majority and [did] not have to." ${ }^{991}$ Election observers, former President Jimmy Carter and former National Security Council staff member, Robert Pastor, would make a similar suggestion, stating that though Aristide began with a mindset that troubled Washington, they were left hopeful

\footnotetext{
${ }^{987}$ Howard W. French, "Haitians' Lament: Anemic Opposition," New York Times, January 20, 1991.

${ }^{988}$ Howard W. French, "Haiti Turnout is Sparse in Legislative Elections," New York Times, January 21, 1991.

${ }^{989}$ Ibid.

${ }^{990}$ French, "Haitians' Lament," New York Times, January 20, 1991.

${ }^{991}$ Ibid.
} 
after a discussion with him about possibly appointing Bazin as his Prime Minister, ${ }^{992}$ the runner up in the presidential race who only garnered $12 \%$ of the vote.

While Aristide made it a point during his campaign to moderate his rhetoric, shifting to a more conciliatory posture towards those he had previously counted as enemies of the Haitian people, many of these groups immediately began their plans to constrain the ability of his government to carry out reforms that would adhere to the will of the poor and working class majority. As he "thanked the United States for its support of the election process, recognized the contribution of the army in guaranteeing the balloting, and said he was willing to cooperate with military officers, private business and opposition political parties to unite the country," 993 these various powerbrokers displayed a cautious pessimism. Though the population demanded wholesale changes to the Haitian Armed Forces, beginning with the retirement of most of the senior officers, a number of Western diplomats were "not encouraging such a restructuring," but would nevertheless avoid making vocal statements against such a move should the rule of law be upheld and human rights respected. ${ }^{994}$ Similarly, Western diplomats stated that while it was true that Aristide had strong popular support, his economic platform focused on reducing corruption and graft in state-owned enterprises, protecting key domestic industries, and land reform simply could not by itself "create a modern economy capable of ending

\footnotetext{
992 Clifford Krauss, "Haitian Victor Reportedly Ready to Soften Stands, New York Times, December 20, 1990.

993 Ibid.

${ }^{994}$ Howard W. French, "Haiti Leader Faces Task of Controlling Military," New York Times, December 20, 1990.
} 
Haiti's poverty" without international support. ${ }^{995}$ "While American commitment to respecting the result of the election was irrevocable, significant development assistance would depend on 'macro-economic policies that are sound,"'1996 essentially the liberal economic policies that were promoted by the IMF, which the population mobilized against during the Avril government.

\section{CONCLUSION}

What the period from the fall of Jean-Claude Duvalier on February 7, 1986, and the election of Jean-Bertrand Aristide on December 16, 1990 reveals about Haiti's democratic transition, was the difference in what the poor and working class expected from democracy, as compared to what the "responsible opposition," as represented by the political parties, along with their supporters amongst the major powers, believed democracy entailed. On the one hand, it was clear that the grassroots organizations of the poor majority conceived of democratization as a process by which they were increasingly integrated into the political decision-making process as autonomous agents, with particular interests in dismantling Haiti's historical structures of injustice and exclusion. Within such a context, democracy takes on a rather radical orientation, particularly if one considers the degree of injustice and exclusion that characterizes Haitian society. On the other hand, the "responsible opposition" and their international supporters, viewed democracy as a process by which the holders of power, particularly the military and the economic elite, agree to share power with a class of professional politicians, as long as

\footnotetext{
${ }^{995}$ Ibid.

${ }^{996}$ Howard W. French, "The World: New Leader of Haitians Offers U.S. a Wary Hand," New York Times, December 23, 1990.
} 
their positions of power within society are not fundamentally threatened. Such an understanding of democracy is rather conservative in orientation.

While in a more egalitarian society, the distance between the agenda of the professional political class and the majority is narrower, and thus demands that democracy serve an instrument of radical change is tempered, in a context such as Haiti's where they are rather disparate, these two conceptions of democracy are diametrically opposed to one another, which explains why Haiti's democratic transition is marred by numerous start and stop fits. The election of Aristide, someone outside of the political class, with strong ties to the grassroots organizations of the poor and working class, fundamentally threatens the interests of power brokers, because he was brought to power by a radical democratic impulse. 


\section{CHAPTER VII.}

\section{CONCLUSION}

For Haiti's poor and working class majority, Jean-Bertrand Aristide's victory in the December 16, 1990 elections represented a proximity to the halls of power that they had not experienced, perhaps since the 19th century, if ever. During his inaugural address, Aristide declared, "From 1791 to 1991, it took 200 years of travel to obtain our second independence. When our mother Haiti gave birth to our first independence, our ancestors had said: Freedom or death...Today, 7 February 1991, on our second independence, we are screaming with all our strength: Democracy or death!"997 This was a sentiment that had been clearly expressed just a month prior.

On January 7, 1991, when a small faction of the Haitian military aligned itself with notorious macoute Roger Lafontant to strangle the Lavalas government in its crib before it could even come to power, the population mobilized to defend what they viewed as the beginnings of their popular democracy. While the Army Chief, General Herard Abraham, was able to reverse the coup, arresting Lafontant and his accomplices, the population mobilized to exact retribution on the sectors of Haitian society believed responsible. With barricades set-up throughout Port-au-Prince and the provincial cities, the population set out in search of macoutes of all stripes. Many would lose "their lives at the hands of the people...lynched, stoned, beaten to death, or burned alive," in what was known as Pere Lebrun. ${ }^{998}$ The population similarly ravaged the homes, offices, and stores

\footnotetext{
997 "President Aristide's Inaugural Address 7 Feb," Port-au-Prince Radio Nationale [English Translation], February 7, 1991, Foreign Broadcast Information Service (FBIS) Daily Reports, Latin America, February 11, 1991.

998 "Destruction Detailed," Port-au-Prince Radio Metropole [English Translation], January 8, 1991,
} 
of those that were viewed as active or tacit Lafontant collaborators. They destroyed the office of Duvalierist newspaper, Le Petit Samedi Soir, and ransacked the home of Hubert de Ronceray of the Mobilization for National Development (MDN) party, who just prior to election-day formed an alliance with Lafontant's Duvalierist Union for National Reconciliation (URN) party. ${ }^{999}$ Next in line were the symbols of the Catholic Church hierarchy. Angry Lavalas supporters ravaged the home of the Apostolic Nuncio and the Vatican Embassy in Haiti. They similarly destroyed the Episcopal Conference building, and the home of the Archbishop of Port-au-Prince, Francois Wolf Ligondé, who in a New Year's homily called on "Haitian citizens" not to be afraid, because "dictatorships [were] based on fear...fear of thieves, fear of attacks, and fear of uprootings to come," a reference to what he called the possibility of Aristide's "socio-Bolshevik" government. ${ }^{1000}$ For many, including human rights advocate Jean-Claude Bajeux, this was tantamount to officially giving "his benediction to the coup." ${ }^{1001}$ The population would also burn the historic Port-au-Prince Cathedral, built in $1821,{ }^{1002}$ where Ligondé's New Years sermon had been held. Along with the Church, the people attacked the private sector. Prior to the election, "one downtown businessman said in a typical assessment of Father Aristide from those in the entrepreneurial class, 'If it comes to a choice between the ultra-left and

Foreign Broadcast Information Service (FBIS) Daily Reports, Latin America, January 9, 1991.

999 "De Ronceray and Lafontant Form Alliance" Port-au-Prince Radio Lumiere Network [English Translation], December 14, 1990, Foreign Broadcast Information Service (FBIS) Daily Reports, Latin America, December 17, 1990.

\footnotetext{
1000 "Bishop Romelus Reacts to Archbishop's Statements," Port-au-Prince Radio Metropole [English Translation], January 04, 1991, Foreign Broadcast Information Service (FBIS) Daily Reports, Latin America, January 7, 1991.

${ }^{1001}$ Howard W. French, "Haiti's Victors Working to Soothe Fears," New York Times, January 11, 1991.

1002 "Port-au-Prince Devastated," Port-au-Prince Radio Metropole [English Translation], January 8, 1991, Foreign Broadcast Information Service (FBIS) Daily Reports, Latin America, January 9, 1991.
} 
the ultra-right, I am ready to form an alliance with the ultra-right."' ${ }^{1003}$ Many commercial businesses would be plundered and destroyed during the turbulence. ${ }^{1004}$ Following the maelstrom, over 75 people were dead, 150 wounded. ${ }^{1005}$

Unlike November 29, 1987, this time the population was not going to wait for Haiti's institutions, which had failed to carry out justice time and time again. Instead they were going to mobilize themselves to ensure that justice would be served. They declared that

The people must completely do away with the Macoutes so that the Macoutes do not completely do away with them. The sole remedy for Macoutes is 'dechoucage' (uprooting) and 'pere lebrun'...All Macoutes, with no exceptions, must be uprooted: Macoutes in priestly robes, Macoutes in blue uniforms, Macoutes in khaki, American Macoutes, and American henchmen Macoutes...We will not give the Macoutes another chance to assassinate the people...It is only the people that can give themselves security. ${ }^{1006}$

While the U.S. condemned the violent reaction of the population to the coup, denouncing what they viewed as Aristide's failure to unequivocally condemn the mob violence, he retorted that "When those that are unarmed stand firm on the ground with their bare hands, in a spirit of solidarity, facing gun-toting individuals, they are crystallizing a divine power to restore justice and democracy." ${ }^{1007}$ Now that the popular

\footnotetext{
${ }^{1003}$ Howard W. French, "Front-Running Priest a Shock to Haiti," New York Times, December 13, 1990.

1004 "Destruction Detailed," Port-au-Prince Radio Metropole [English Translation], January 8, 1991, Foreign Broadcast Information Service (FBIS) Daily Reports, Latin America, January 9, 1991.

1005 "Army Reveals Details of Coup Attempt, Arrests," Port-au-Prince Radio Nationale [English Translation], January 14, 1991, Foreign Broadcast Information Service (FBIS) Daily Reports, Latin America, January 15, 1991.

1006 "Further on Damages Throughout Port-au-Prince," Port-au-Prince Radio Cacique [English Translation], January 8, 1991, Foreign Broadcast Information Service (FBIS) Daily Reports, Latin America, January 10, 1991.

1007 "President-Elect Aristide Outlines Tasks, Goals," Mexico City NOTIMEX [English Translation], January 13, 1991, Foreign Broadcast Information Service (FBIS) Daily Reports, Latin America, January
} 
mobilization of the poor and working class masses had given him an election victory, had defended this victory when it came under threat, Aristide believed it was important to bind this mobilization to the process of governing. With Operation Lavalas over, it was now time for Organization Lavalas to "build the country we want, a country with mutual respect, full employment, and justice for all; ${ }^{1008}$ a country where the poor are able to share in the country's wealth. Aristide declared that this time "the situation [would] really change, because we are organizing ourselves so the situation can change." ${ }^{1009} \mathrm{He}$ promised that his government would remain faithful to the people "in order to draw nearer toward the national direction."1010

Nevertheless, Aristide's government would have to straddle the line between the Haitian military, which was still heavily infiltrated with Duvalierists, and had gotten used to the spoils of power, from contraband smuggling and drug trafficking, to repressing and extorting the peasant population of the Haitian countryside; the legislature, which despite its lack of popularity, viewed the process of governing as its prerogative; the Haitian economic elite, who were wholly antagonistic to any economic reforms that would redistribute the nation's resources more equitably; and the United States, which also rejected the political and economic ideological orientation of the newly established Aristide government. As the Aristide government vacillated between the agenda demanded by the grassroots organizations, and policies advocated by the Haitian elite and

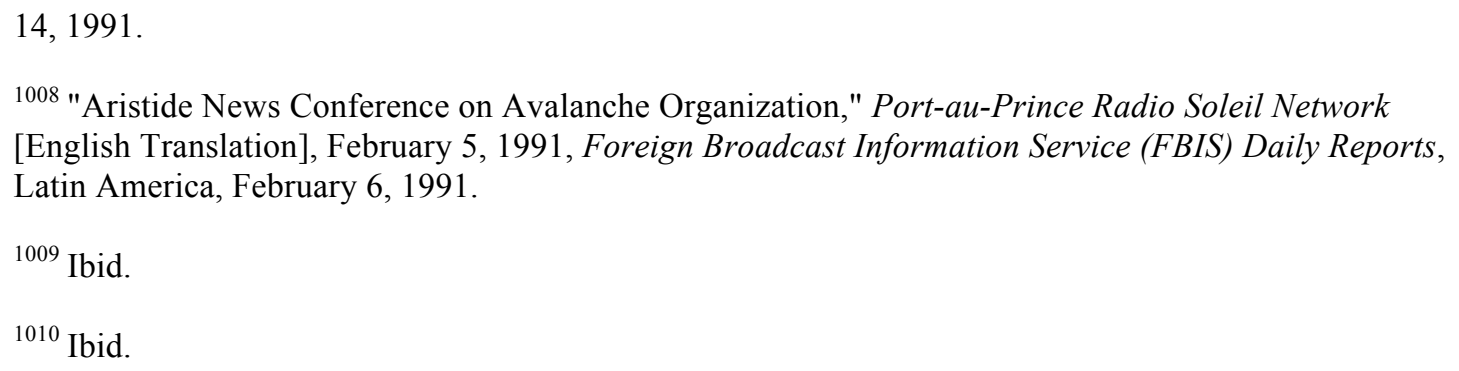


U.S. foreign policy establishment, in order to receive desperately needed aid, an already tenuous situation would spiral into a political crisis, leading to the ouster of his government.

Though the Haitian Armed Forces seemed to be the most significant threat to the viability of a Lavalas government, the various fissures within the military that emerged over the 5-year period of transition left it relatively weakened, at least initially, in the face of an Aristide government with a mobilized population behind it and international legitimacy. "Within hours of being sworn in...Aristide said that all but two of the army's eight generals would be given a 'well-earned retirement."'1011 In the aftermath of the dechoukaj against Lafontant and his supporters, "analysts say the popular new President decided that the time was right for a radical restructuring of a force regarded here as repressive and corrupt..." ${ }^{1012}$ Aristide would reinstate and promote a number of military officers previously discharged by the Prosper Avril government due to their ties to the September 17, 1988 uprising against Duvalierists within the military. ${ }^{1013}$ Alongside reforms within the Haitian Armed Forces, the Aristide government also worked to fundamentally transform the Haitian judicial system. This would begin with a major reshuffling of judges and prosecutors, ${ }^{1014}$ and the selection of entirely new members of

\footnotetext{
${ }^{1011}$ Howard W. French, "Haiti's New Leader Takes on the Army," New York Times, February 9, 1991. 1012 Ibid.

1013 "Discharged Military Officers Reinstated, Promoted," Port-au-Prince Radio Metropole [English Translation], February 14, 1991, Foreign Broadcast Information Service (FBIS) Daily Reports, Latin America, February 19, 1991.

1014 "Government Announces Reforms in Justice System," Port-au-Prince Radio Soleil [English Translation], March 14, 1991, Foreign Broadcast Information Service (FBIS) Daily Reports, Latin America, March 15, 1991.
} 
the Haitian Supreme Court. ${ }^{1015}$ With a new judiciary in place, the Aristide government would begin pursuing justice against those who committed atrocities against the Haitian people. An inter-ministerial commission was established to review judicial dossiers and resume investigations that were still pending on the various killings carried out during the transition period, such as the massacres at "Jean-Rabel, Piatte, Saint-Jean Bosco, Danty, and so on." ${ }^{1016}$ Arrest warrants would be issued for Nichole Poitevien accused of involvement in the Jean-Rabel massacre; Polynice Volcy, a suspect in the Gervais massacre in Saint-Marc; and former CNG figure, William Regala, accused of orchestrating the November 29, 1987 election-day massacre. ${ }^{1017}$

The Aristide government would similarly pursue those who were believed to have committed economic injustices against the Haitian people, starting with the former provisional president, Ertha Pascal Trouillot. While the decree preventing Trouillot and over 200 members of her government from the leaving the country would be characterized by the Haitian political class and the U.S. foreign policy establishment as...the impetus for this action by the Aristide government actually came from the grassroots organizations. A day before his inauguration, 381 members of the Ti Legliz petitioned their new president, asking that since this was "the first time the country [would] have an honest government," that it had an obligation to "take back the people's

1015 "Supreme Court Judges Sworn in by Aristide," Port-au-Prince Radio Metropole [English Translation], March 18, 1991, Foreign Broadcast Information Service (FBIS) Daily Reports, Latin America, March 21, 1991.

\footnotetext{
1016 "Ministerial Commission to Investigate Massacres," Port-au-Prince Le Nouvelliste [English Translation], February 27, 1991, Foreign Broadcast Information Service (FBIS) Daily Reports, Latin America, February 28, 1991.

1017 "Minister Orders Arrest of Massacre Participants," Port-au-Prince Radio Soleil [English Translation], March 14, 1991, Foreign Broadcast Information Service (FBIS) Daily Reports, Latin America, March 15, 1991.
} 
money." ${ }^{1018}$ They called on the new Aristide government to prevent Trouillot, her ministers, and all other former government officials from leaving the country without giving the people an accounting of how public funds were handed over to his administration. "We believe in you, Titide [Father Aristide's nickname]. You can trust in us to set up barriers so that no plunderer leaves the country with a pile of money that they are going to enjoy abroad while we have nothing to eat here." ${ }^{1019}$ The Haitian judiciary would be mobilized to prosecute macoutes accused of embezzling public funds. ${ }^{1020}$

Aristide would also seek to reorient the relationship between the state and the population, from one of economic exploitation to one of economic justice. Aristide declared his government's commitment to the people by renouncing his salary in the face of the country's immense poverty. "I, too, come to say that I can also give my meager contribution in another way. This means that the day of the president getting paid 50,000 gourdes $[\$ 10,000]$ per month is over...this is a scandal in a country where people do not have food to eat, where people cannot find a job...No matter how much you pay me, I will accept it." ${ }^{1021}$ This would be a first step towards reforming the state, shifting it from an instrument of wealth acquisition for the political class towards an instrument of social justice. The Papaye Peasants Movement (MPP) would follow Aristide's call, proposing

\footnotetext{
1018 "Petition Seeks Ban on Recent Leaders Leaving," Port-au-Prince Radio Soleil Network [English Translation], February 6, 1991, Foreign Broadcast Information Service (FBIS) Daily Reports, Latin America, February 7, 1991.

${ }^{1019}$ Ibid.

1020 "Justice Ministry to Prosecute Embezzling Macoutes," Port-au-Prince Radio Soleil [English Translation], March 19, 1991, Foreign Broadcast Information Service (FBIS) Daily Reports, Latin America, March 21, 1991.

1021 "President Aristide's Inaugural Address 7 Feb," Port-au-Prince Radio Nationale [English Translation], February 7, 1991, Foreign Broadcast Information Service (FBIS) Daily Reports, Latin America, February $11,1991$.
} 
that the salaries of all state employees be lowered. According to the MPP, how could a member of Parliament demand $\$ 2,000$ or $\$ 3,000$ a month in salary, when "three-fourths of the people who sent the deputies and senators to the chambers cannot afford to eat even twice a day" or "afford to send their children to school." ${ }^{1022}$ Or, when "a school teacher who is educating our children does not even get \$200?"1023 MPP declared that one of the first ways that members of Parliament could show that they had not forgotten the people they represented, was to lower their salaries in light of the dire financial straits faced by the country's poor majority. In order to address corruption and graft, Aristide appeared on national television one month after taking office to list the monthly salary expenses of each government ministry, along with the "number of cars and drivers in each." ${ }^{1024}$

Alongside efforts to reign in the economic excesses of those in positions of power, the Lavalas government also sought to wean the country off of its dependence on international aid. This would begin with the popular mobilization of the grassroots organizations to raise money for the government a few coins at a time. The organization of a "Campaign for National Dignity" by Port-au-Prince's Community of Small Churches (Ti Communaute l'Eglise) via radio broadcasts, would serve as a powerful symbolic challenge to the country's elite to also contribute their fair share. On March 24, 1991, the

\footnotetext{
1022 "MPP Proposes Lowering State Employee Salaries," Port-au-Prince Radio Soleil Network [English Translation], February 15, 1991, Foreign Broadcast Information Service (FBIS) Daily Reports, Latin America, February 19, 1991.

${ }^{1023}$ Ibid.

1024 "Aristide Views First Month as President," Port-au-Prince Radio Haiti-Inter [English Translation], March 8, 1991, Foreign Broadcast Information Service (FBIS) Daily Reports, Latin America, March 11, 1991.
} 
Ti Legliz would raise nearly 500,190 gourdes, or $\$ 100,038$. While they acknowledged that this amount was nothing in comparison to what the government actually needed to carry out a pro-poor agenda, nevertheless, it represented an important coming together of ordinary Haitians, who, with "the little money that they had to live on," brought five and ten cents at a time, supported the idea of a "Haiti for all of us and all of us for Haiti." ${ }^{1025}$

The "Campaign for National Dignity" was very similar to the proto-noiriste President Dumarsais Estimé's 1947 nationalist call to all Haitians to help "Pay Five Million" (Payons Cinq Millions) in order to reduce the country's outstanding debt to the United States, a legacy of the 19-year U.S. occupation from 1915 to 1934. Having been denied a loan from the EX-IM bank due to his government's electoral promise of "financial liberation," Estimé would make a "stirring radio address imploring the nation to assist him in raising an internal loan for the repayment of the debt...claiming that 'with them or without them we will liberate the country."' Members of the legislature, the private sector, workers, and even school children would get behind the effort, helping to raise \$7.6 million in three months, a feat unmatched in Haitian history. The people declared, "Dessalines liberated the country politically and now Estimé [has] liberated the country economically." ${ }^{1026}$ Aristide would seek to do the same.

In a speech, President Aristide "stressed that the country's economic start [could] be achieved with Haitian funds." ${ }^{1027}$ Paraphrasing Pope John-Paul II, Aristide declared

\footnotetext{
1025 "TKL Organizes Collection to Aid Government," Port-au-Prince Radio Soleil Network [English Translation], March 25, 1991, Foreign Broadcast Information Service (FBIS) Daily Reports, Latin America, March 28, 1991.

${ }^{1026}$ Matthew J. Smith, Red and Black in Haiti: Radicalism, Conflict, and Political Change, 1934-1957 (Chapel Hill: University of North Carolina Press, 2009): 113-114.

1027 "Youth Groups Demonstrate Support for Aristide," Port-au-Prince Radio Metropole [English
} 
that "all private property has a social mortgage, and added: to mortgage the sovereignty is to reject dignity." ${ }^{1028} \mathrm{He}$ declared that his plan for renewing the national economy would "not be dictated from abroad," but rather, "grounded in Haitian reality," and would depend on the national bourgeoisie's investment in the country. ${ }^{1029}$ In a meeting with representatives of the country's private sector, Aristide spoke of the need for dialogue between the two powers: the political and the economic. "I am part of the political power, as you are part of the economic power," Aristide announced. But, it is the country's 6.5 million inhabitants, the people themselves, "who are a bridge between economics and politics."1030

While the Aristide government was able to raise a last minute loan of $\$ 5.3$ million from the Haitian elite during a period of acute economic crisis, through what some interpreted as a subtle threat, the economic and political constraints on his government became increasingly apparent. The United States Agency for International Development (USAID) would suspend the millions it had been funneling into Haiti to promote lowcost investment in the light-manufacturing sector due to what it deemed were decisions that undermined the country's long-term economic growth. ${ }^{1031}$ The Agency particularly

Translation], March 25, 1991, Foreign Broadcast Information Service (FBIS) Daily Reports, Latin America, March 28, 1991.

${ }^{1028}$ Ibid.

1029 "Aristide Reviews Three-Month Progress," Port-au-Prince Radio Metropole [English Translation], May 8, 1991, Foreign Broadcast Information Service (FBIS) Daily Reports, Latin America, May 13, 1991.

1030 "Aristide, Private Sector Debate Economic Solution," Port-au-Prince Radio Metropole [English Translation], April 2, 1991, Foreign Broadcast Information Service (FBIS) Daily Reports, Latin America, April 4, 1991.

${ }^{1031}$ Peter Hallward, "Damming the Flood: Haiti and the Politics of Containment," (London: Verso 2007): 37. 
rejected Aristide's efforts to raise the country's minim wage from 15 gourdes to 28.5 gourdes a day, or essentially from $\$ 3$ to $\$ 5.70$ a day." ${ }^{1032}$ Aristide's government would also face resistance from the Haitian private sector, who argued that it was the appropriate economic solution for the country considering increased competition for lowwage labor from nearby Caribbean countries such as Jamaica and the Dominican Republic. They argued that raising wages would cause industry to leave Haiti, thus increasing the unemployment rate and thus poverty. ${ }^{1033}$

Six months into power, the Lavalas government would be forced to go to the World Bank to secure $\$ 442$ million in new loans and aid for Haiti. "As alternative efforts...failed, Haitians close to the President say he gradually resigned himself to contracting large-scale international assistance to bring new jobs, clean drinking water and passable roads to the hemisphere's poorest country."1034

While the Aristide government was being forced towards accommodation, the grassroots organizations increasingly criticized what they viewed as the lack of substantive change to their daily circumstances. In fact, in his first few weeks in power, as many workers in government ministries and state owned enterprises mobilized against holdovers from the military government, Aristide would repudiate what he called "untimely uprooting operations," declaring that reforms of the bureaucracy would not be carried through witch-hunts. He would also condemn the increasing number of popular

\footnotetext{
1032 "Aristide, Private Sector Debate Economic Solution," Port-au-Prince Radio Metropole, April 2, 1991. ${ }^{1033}$ Ibid.

${ }^{1034}$ Howard W. French, "After 6 Months of Changes, Haiti is Surprised by its Leaders," New York Times, August 4, 1991.
} 
occupations of unused public and private land across the country. ${ }^{1035}$ As the Aristide government sought to establish price controls on essential goods, particularly rice, cement, and refined sugar, ${ }^{1036}$ throughout the provinces, thousands of demonstrators took to the streets to protest the high cost of living, ransacking businesses and warehouses believed to be stockpiling goods in order to inflate their prices. ${ }^{1037}$ The organization Tet Kole Ti Paysan Haitien believed that some sectors of the society had "an interest in hurting the people" in order to "sow confusion in popular matters." 1038

While during the four-year transition period, Aristide's message served to magnify the perspective of Haiti's poor and marginalized majority, his presidential candidacy in the 1990 elections unwittingly legitimized a political process that was never designed to be inclusive of this class or its grassroots organizations. Nevertheless, Aristide believed that he could link the mobilization of the masses during the elections to the power of the Haitian state in order to push forward a people's agenda. Once in the presidency, it became increasingly evident that elections were intended to be a vehicle to empower politicians and political parties, and not the movement. The presidency served to constrain Aristide's previous clarion call for the radical transformation of Haitian society

\footnotetext{
1035 "AFP Reviews Aristide's First Month in Office," Port-au-Prince Radio Metropole [English Translation], March 7, 1991, Foreign Broadcast Information Service (FBIS) Daily Reports, Latin America, March 11, 1991.

1036 "Youth Groups Demonstrate Support for Aristide," Port-au-Prince Radio Metropole [English Translation], March 25, 1991, Foreign Broadcast Information Service (FBIS) Daily Reports, Latin America, March 28, 1991.

1037 "Calm Returns Following Uprising in Cap Haitien," Port-au-Prince Radio Nationale [English Translation], April 16, 1991, Foreign Broadcast Information Service (FBIS) Daily Reports, Latin America, April 17, 1991.

1038 "Peasants Blame 'Imperialism,"' Port-an-Prince Radio Haiti-Inter [English Translation], April 19, 1991, Foreign Broadcast Information Service (FBIS) Daily Reports, Latin America, April 24, 1991.
} 
through mass mobilization. Having adopted a more reformist position, Aristide increasingly felt the need to compromise with many of the reactionary forces in government and society that he previously spoke out against. Despite his efforts to pursue a moderate reformist agenda, he was vehemently opposed by the political parties and by U.S. foreign policy establishment. In a society such as Haiti's where those who held power always sought to do so absolutely, even moderate sensible calls for reform and justice were deemed radical. Perhaps most threatening to the military and its backers in Haiti and abroad, was the intense pressure that the grassroots movement placed on Aristide's government to move beyond the obstructionism faced by his government from the legislature, towards the use of executive power for radical change, without concern for the niceties of polyarchy. 


\section{LIST OF REFERENCES}

"Action Committee Calls for New Elections," Port-au-Prince Radio Metropole [English Translation], April 25, 1988, Foreign Broadcast Information Service (FBIS) Daily Reports, Latin America, April 27, 1988.

"Adopts Political Parties Bill," Paris AFP [English Translation], June 9, 1985, Foreign Broadcast Information Service (FBIS) Daily Reports, Latin America, June 11, 1985.

"AFP Reviews Aristide's First Month in Office," Port-au-Prince Radio Metropole [English Translation], March 7, 1991, Foreign Broadcast Information Service (FBIS) Daily Reports, Latin America, March 11, 1991.

"Alliance Proposes Solution to Current Crisis," Port-au-Prince Radio Soleil Network [English Translation], November 10, 1989, Foreign Broadcast Information Service (FBIS) Daily Reports, Latin America, November 15, 1989.

"Anglican Church Calls for Reconciliation," Port-au-Prince Radio Metropole [English Translation], February 2, 1988, Foreign Broadcast Information Service (FBIS) Daily Reports, Latin America, February 10, 1988.

"Ann Fè Rèl Gonayiv ak Lezòt Vil Yo Tounen You Fòs!," Kontenjan 28 Jiyè, Desanm 85/December 85; found in Schomburg Center, Haiti Dechoucaj Collection, Box1, Folder 27 - Background Material, Haitians in NY, Political Leaflets 1980-86.

"ANOP Holds News Conference on Cost of Living," Port-au-Prince Radio Soleil Network [English Translation], September 14, 1989, Foreign Broadcast Information Service (FBIS) Daily Reports, Latin America, September 19, 1989.

"ANOP Rejects Dialogue Offer," Port-au-Prince Radio Soleil Network [English Translation], September 19, 1988, Foreign Broadcast Information Service (FBIS) Daily Reports, Latin America, September 20, 1988.

"Anti-American Protests to be Held 28 July," Port-au-Prince Radio AntillesInternationales [English Translation], July 24, 1987, Foreign Broadcast Information Service (FBIS) Daily Reports, Latin America, July 28, 1987.

"Anti-Manigat Slogans, Abuse by Soldier Reported," Port-au-Prince Radio Metropole [English Translation], April 11, 1988, Foreign Broadcast Information Service (FBIS) Daily Reports, Latin America, April 13, 1988.

"APN Opposes Elections," Port-au-Prince Radio Nationale [English Translation], September 16, 1987, Foreign Broadcast Information Service (FBIS) Daily Reports, Latin America, September 18, 1987. 
"APN Protests Contract," Port-au-Prince Radio Metropole [English Translation], July 28, 1989, Foreign Broadcast Information Service (FBIS) Daily Reports, Latin America, July 31, 1989.

"Area Leaders Offer Assistance With Elections," Bridgetown CANA [English Translation], December 2, 1987, Foreign Broadcast Information Service (FBIS) Daily Reports, Latin America, December 3, 1987.

"Aristide Calls for 'Revolution,"' Paris AFP [English Translation], December 2, 1987, Foreign Broadcast Information Service (FBIS) Daily Reports, Latin America, December 3, 1987.

Aristide, Jean-Bertrand and Wargny, Christophe. Aristide: An Autobiography. Maryknoll, NY: Orbis Books, 1993.

"Aristide News Conference on Avalanche Organization," Port-au-Prince Radio Soleil Network [English Translation], February 5, 1991, Foreign Broadcast Information Service (FBIS) Daily Reports, Latin America, February 6, 1991.

"Aristide Outlines Campaign Strategy, Objectives," Havana Tele Rebelde Network [English Translation], October 24, 1990, Foreign Broadcast Information Service (FBIS) Daily Reports, Latin America, October 25, 1990.

"Aristide, Private Sector Debate Economic Solution," Port-au-Prince Radio Metropole [English Translation], April 2, 1991, Foreign Broadcast Information Service (FBIS) Daily Reports, Latin America, April 4, 1991.

"Aristide Reviews Three-Month Progress," Port-au-Prince Radio Metropole [English Translation], May 8, 1991, Foreign Broadcast Information Service (FBIS) Daily Reports, Latin America, May 13, 1991.

"Aristide Views First Month as President," Port-au-Prince Radio Haiti-Inter [English Translation], March 8, 1991, Foreign Broadcast Information Service (FBIS) Daily Reports, Latin America, March 11, 1991.

"Armed Forces 'Temporarily Rescind' Measures," Port-au-Prince Radio Nationale [English Translation], June 16, 1988, Foreign Broadcast Information Service (FBIS) Daily Reports, June 17, 1988.

"Armed Forces Reorganize Government Council," Paris AFP [English Translation], March 21, 1986, Foreign Broadcast Information Service (FBIS) Daily Reports, Latin America, March 24, 1986. 
"Army Demands Democracy," Paris AFP [English Translation], September 18, 1988, Foreign Broadcast Information Service (FBIS) Daily Reports, Latin America, September 19, 1988.

"Army Forces Sent to Quell Disturbances," Paris AFP [English Translation], February 25, 1986, Foreign Broadcast Information Service (FBIS) Daily Reports, Latin America, February 26, 1986.

"Army Promotions, Changes," Paris AFP [English Translation], June 21, 1988, Foreign Broadcast Information Service (FBIS) Daily Reports, Latin America, June 21, 1988.

"Army Reveals Details of Coup Attempt, Arrests," Port-au-Prince Radio Nationale [English Translation], January 14, 1991, Foreign Broadcast Information Service (FBIS) Daily Reports, Latin America, January 15, 1991.

"Army 'Unlikely' to Retain Power Past 1988," Bridgetown CANA [English Translation], December 4, 1986, Foreign Broadcast Information Service (FBIS) Daily Reports, Latin America, December 5, 1986.

"Assemblage Calls Protest Strike," Port-au-Prince Radio Soleil Network [English Translation], November 6, 1989, Foreign Broadcast Information Service (FBIS) Daily Reports, Latin America, November 7, 1989.

"Assemblage Says Avril Must Go; March Planned," Port-au-Prince Radio Metropole [English Translation], October 31, 1989, Foreign Broadcast Information Service (FBIS) Daily Reports, Latin America, November 2, 1989.

Averill, Gage. A day for the hunter, a Day for the Prey: Popular Music and Power in Haiti. Chicago, Illinois: University of Chicago Press, 1997.

"Avril Addresses Nation, Newly Installed Cabinet," Port-au-Prince Domestic Service [English Translation], September 19, 1988, Foreign Broadcast Information Service (FBIS) Daily Reports, Latin America, September 20, 1988.

"Avril Assassination Plot Disclosed," Port-au-Prince Radio Soleil Network [English Translation], November 3, 1989, Foreign Broadcast Information Service (FBIS) Daily Reports, Latin America, November 6, 1989.

"Avril Discusses 27 September Strike Demands," Port-au-Prince Radio Soleil Network [English Translation], September 29, 1989, Foreign Broadcast Information Service (FBIS) Daily Reports, Latin America, October 3, 1989. 
"Avril, Claude Discuss Election Prospects," Port-au-Prince Radio Metropole [English Translation], September 23, 1988, Foreign Broadcast Information Service (FBIS) Daily Reports, Latin America, September 26, 1988.

"Avril, Entourage Depart for Taiwan 7 January," Port-au-Prince Radio Metropole [English Translation], January 8, 1990, Foreign Broadcast Information Service (FBIS) Daily Reports, Latin America, January 9, 1990.

"Avril Interview on Election, Strike Plans," Port-au-Prince Radio Metropole [English Translation], September 26, 1989, Foreign Broadcast Information Service (FBIS) Daily Reports, Latin America, September 29, 1989.

Baloyra, Enrique A. "Central America on the Reagan Watch: Rhetoric and Reality." Journal of Interamerican Studies and World Affairs 27, no. 1 (February 1985): 35-62.

"Barrack Besieged; 1 Killed," Bonaire Trans World Radio [English Translation], November 8, 1986, Foreign Broadcast Information Service (FBIS) Daily Reports, Latin America, November 10, 1986.

Baur, John E. "Faustin Soulouque, Emperor of Haiti His Character and His Reign." The Americas 6, no. 2 (October 1949): 131-166.

"Bazin, Gourgue, Dejoie, Claude Meet Press," Port-au-Prince Radio Metropole [English Translation], December 22, 1987, Foreign Broadcast Information Service (FBIS) Daily Reports, Latin America, December 23, 1987.

"Bazin on Possibility of Single Candidate," Port-au-Prince Le Nouvelliste [English Translation], December 17, 1987, Foreign Broadcast Information Service (FBIS) Daily Reports, Latin America, December 24, 1987.

"Bazin: Wants Deeds Not Words," Port-au-Prince Radio Metropole [English Translation], February 9, 1988, Foreign Broadcast Information Service (FBIS) Daily Reports, Latin America, February 11, 1988.

Beaulieu, Serge. "7 Killed As Police Break Up Demonstration," Madrid EFE [English Translation], April 26, 1986, Foreign Broadcast Information Service (FBIS) Daily Reports, Latin America, April 28, 1986.

Becker, Don. "Rockefeller is Given Warm Haiti Welcome." The Times-News, July 2 , 1969.

Bigart, Homer. "U.S. Envoy Favors More Aid to Haiti: Urges \$750,000 Program for Farm Projects. New York Times, April 26, 1971. 
"Bishop Romelus Reacts to Archbishop's Statements," Port-au-Prince Radio Metropole [English Translation], January 04, 1991, Foreign Broadcast Information Service (FBIS) Daily Reports, Latin America, January 7, 1991.

"Blames Cuban-Trained Persons," Paris AFP [English Translation], July 31, 1987, Foreign Broadcast Information Service (FBIS) Daily Reports, Latin America, August 3, 1987.

Bohning. "Cleric Takes Center Stage as Vote Nears.” New York Times, 1990.

"'Brigades' Group Seeks Justice Before Elections," Port-au-Prince Radio Soleil Network [English Translation], September 29, 1988, Foreign Broadcast Information Service (FBIS) Daily Reports, Latin America, October 3, 1988.

"Broad-Based Coalition Stages Protest: '57 Organizations'--New Force in Haiti," Los Angeles Times, July 11, 1987.

"Called Man of the Moment," Paris AFP [English Translation], January 24, 1988, Foreign Broadcast Information Service (FBIS) Daily Reports, Latin America, January 25, 1988.

"Calls for Support," Port-au-Prince Radio Lumiere Network [English Translation], July 16, 1987, Foreign Broadcast Information Service (FBIS) Daily Reports, Latin America, July 17, 1987.

"Calm Returns Following Uprising in Cap Haitien," Port-au-Prince Radio Nationale [English Translation], April 16, 1991, Foreign Broadcast Information Service (FBIS) Daily Reports, Latin America, April 17, 1991.

"Caribbean Leaders Meet Namphy, Welcome Vote," Bridgetown CANA [English Translation], December 11, 1987, Foreign Broadcast Information Service (FBIS) Daily Reports, Latin America, December 15, 1987.

"Caribbean Leaders to Observe," Bridgetown CANA [English Translation], January 12, 1988, Foreign Broadcast Information Service (FBIS) Daily Reports, Latin America, January 13, 1988.

Carleton, David, and Stohl, Michael. "The Foreign Policy of Human Rights: Rhetoric and Reality from Jimmy Carter to Ronald Reagan." Human Rights Quarterly 7, no. 2 (May 1985): 205-229.

Casey, Matthew. "From Haiti to Cuba and Back: Haitians' Experiences of Migration, Labor, and Return, 1900-1940," Ph.D. Dissertation, University of Pittsburgh, Pennsylvania, 2012, D-Scholarship. 
"CATH Cites 'Pilots' to Derail 17 Sep Movement," Port-au-Prince Radio Soleil Network [English Translation], October 10, 1988, Foreign Broadcast Information Service (FBIS) Daily Reports, Latin America, October 12, 1988.

"CATH Grants 26 Jul Press Conference," Port-au-Prince Radio Haiti-Inter [English Translation], July 27, 1989, Foreign Broadcast Information Service (FBIS) Daily Reports, Latin America, July 31, 1989.

"CATH Reacts," Port-au-Prince Radio Soleil Network [English Translation], July 12, 1988, Foreign Broadcast Information Service (FBIS) Daily Reports, Latin America, July 13, 1988.

"CATH Secretary General Cites Aims of Strike," Port-au-Prince Radio Soleil Network [English Translation], November 7, 1989, Foreign Broadcast Information Service (FBIS) Daily Reports, November 8, 1989.

"CCC Leader on Haiti's Political Situation," Bridgetown CANA [English Translation], February 24, 1988, Foreign Broadcast Information Service (FBIS) Daily Reports, Latin America, February 25, 1988.

"CED Communique, Bazin on Elections," Port-au-Prince Radio Metropole [English Translation], January 13, 1988, Foreign Broadcast Information Service (FBIS) Daily Reports, Latin America, January 14, 1988.

"CED Declaration," Port-au-Prince Radio Soleil Network [English Translation], January 19, 1988, Foreign Broadcast Information Service (FBIS) Daily Reports, Latin America, January 20, 1988.

"CED Issues Communique Against Intervention," Port-au-Prince Radio Soleil Network [English Translation], January 11, 1988, Foreign Broadcast Information Service (FBIS) Daily Reports, Latin America, January 12, 1988.

"CEP Eliminates 8 Presidential Candidates," January 10, 1988, Foreign Broadcast Information Service (FBIS) Daily Reports, Latin America, January 11, 1988.

"CEP Officials Seek Embassy Protection," Hamburg DPA [English Translation], November 30, 1987, Foreign Broadcast Information Service (FBIS) Daily Reports, Latin America, December 1, 1987.

"CEP President Auguste Asks for People's Trust," Port-au-Prince Radio Nationale [English Translation], November 13, 1989, Foreign Broadcast Information Service (FBIS) Daily Reports, Latin America, November 15, 1989. 
"CEP Sets Guidelines for November Elections," Port-au-Prince Radio Metropole [English Translation], July 15, 1987, Foreign Broadcast Information Service (FBIS) Daily Reports, Latin America, July 16, 1987.

Charles, Jacqueline. "Former Haiti President Leslie Manigat Dead at 83, Miami Herald, June 27, 2014.

"Charles Willing to Meet With Haiti's Manigat," Bridgetown CANA [English Translation], April 16, 1988, Foreign Broadcast Information Service (FBIS) Daily Reports, Latin America, April 20, 1988.

Chomsky, Noam. Year 501: The Conquest Continues. Boston: South End Press, 1993.

"Christian Democratic Leader Warns of Communism," Port-au-Prince Domestic Service [English Translation], July 13, 1987, Foreign Broadcast Information Service (FBIS) Daily Reports, Latin America, July 14, 1987.

"Church Attacks Instrumental," Port-au-Prince Radio Soleil Network [English Translation], September 18, 1988, Foreign Broadcast Information Service (FBIS) Daily Reports, Latin America, September 19, 1988.

"Cites U.S. Position," Port-au-Prince Radio Metropole [English Translation], February 7, 1990, Foreign Broadcast Information Service (FBIS) Daily Reports, Latin America, February 9, 1990.

"Civilian Organizations Issue Manifesto," Port-au-Prince Radio Metropole [English Translation], January 4, 1988, Foreign Broadcast Information Service (FBIS) Daily Reports, Latin America, January 5, 1988.

"Clashes Result in 10 Deaths, 57 Injured," Paris AFP [English Translation], July 1, 1987, Foreign Broadcast Information Service (FBIS) Daily Reports, Latin America, July 2, 1987.

"CNG Annuls Decree," Paris AFP [English Translation], July 2, 1987, Foreign Broadcast Information Service (FBIS) Daily Reports, Latin America, July 6, 1987.

"CNG Appoints Provisional Electoral Council," Paris AFP [English Translation], December 12, 1987, Foreign Broadcast Information Service (FBIS) Daily Reports, Latin America, December 14, 1987.

"CNG Dissolves CEP," Paris AFP [English Translation], November 29, 1987, Foreign Broadcast Information Service (FBIS) Daily Reports, Latin America, November 30, 1987. 
"CNG Invites Observers to 17 Jan Elections," Port-au-Prince Radio Nationale [English Translation], January 12, 1988, Foreign Broadcast Information Service (FBIS) Daily Reports, Latin America, January 13, 1988.

Coalition for Haitian Refugees. "No Greater Priority: Judicial Reform in Haiti, 1995," in A Haiti Anthology: Libète. Princeton, NJ: Markus Wiener Publishers, 1999.

Collier, David and Levitsky, Steven. "Democracy with Adjectives: Conceptual Innovation in Comparative Research.” World Politics 49, no. 3 (April 1997): 430451.

Comhaire, Jean L. "The Haitian 'Chef de Section.'" American Anthropologist 57, no. 3 (1955): 620-624.

"Commando Murders Man; Cost of Land Protested," Port-au-Prince Radio Soleil Network [English Translation], April 22, 1988, Foreign Broadcast Information Service (FBIS) Daily Reports, Latin America, April 25, 1988.

"Commentary Criticizes U.S. Role in Haiti's Affairs," Havana International Service [English Translation], February 15, 1986, Foreign Broadcast Information Service (FBIS) Daily Reports, Latin America, February 20, 1986.

"Commentary on Return of Haitian Tonton Macoutes," Havana International Service [English Translation], October 31, 1986, Foreign Broadcast Information Service (FBIS) Daily Reports, Latin America, November 4, 1986.

"Committee Restructuring Protested," Port-au-Prince Radio Soleil Network, May 12, 1988.

"Communal Sections on Official Election Results," Port-au-Prince Radio Nationale [English Translation], March 8, 1988, Foreign Broadcast Information Service (FBIS) Daily Reports, Latin America, March 9, 1988.

"Communist Leader Bourjolly Expelled," Paris AFP [English Translation], January 21, 1990, Foreign Broadcast Information Service (FBIS) Daily Reports, Latin America, January 22, 1990.

"Conacom Responds to Economic Measures," Port-au-Prince Radio Metropole [English Translation], August 3, 1989, Foreign Broadcast Information Service (FBIS) Daily Reports, Latin America, August 4, 1989.

"Constituent Assembly Issues Electoral Rules," Paris AFP [English Translation], February 25, 1987, Foreign Broadcast Information Service (FBIS) Daily Reports, Latin America, February 26, 1987. 
"Consultations Under Way With New Haitian Government," Beijing Xinhua [English Translation], February 8, 1986, Foreign Broadcast Information Service (FBIS) Daily Reports, China, February 12, 1986.

"Contract Signed to Develop Free Zone," Port-au-Prince Radio Haiti-Inter [English Translation], July 27, 1989, Foreign Broadcast Information Service (FBIS) Daily Reports, Latin America, July 31, 1989.

Corbett, Bob. "Democracy and the Ti Legliz Movement." Bob Corbett's Haiti Page, Webster University, June 1999, http://www2.webster.edu/ corbetre/haiti/misctopic/ti-legliz/democracy.htm.

- "The 1805 Constitution of Haiti," Bob Corbett's Haiti Page, Webster University, April 4, 1999, http://www2.webster.edu/ corbetre/haiti/history/earlyhaiti/1805const.htm.

"Cost of Land Leasing in Northwest Protested," Port-au-Prince Radio Metropole [English Translation], April 20, 1988, Foreign Broadcast Information Service (FBIS) Daily Reports, Latin America, April 22, 1988.

"Council Announces Dissolution of Parliament," Paris AFP [English Translation], February 10, 1986, Foreign Broadcast Information Service (FBIS) Daily Reports, Latin America, February 10, 1986.

"Coup Result of Power Struggle," Port-au-Prince Radio Soleil Network [English Translation], June 24, 1988, Foreign Broadcast Information Service (FBIS) Daily Reports, Latin America, June 27, 1988.

"Creation of Local Affairs Councils Likely," Port-au-Prince Radio Metropole [English Translation], June 29, 1988, Foreign Broadcast Information Service (FBIS) Daily Reports, Latin America, July 1, 1988.

"CWC Urges Return of Exiles be Expedited," Bridgetown CANA [English Translation], March 24, 1986, Foreign Broadcast Information Service (FBIS) Daily Reports, Latin America, March 25, 1986.

Dahl, Robert A. Democracy and its Critics. New Haven: Yale University Press, 1989.

- On Democracy. New Haven: Yale University Press, 1998.

Danner, Mark D. “The Struggle for a Democratic Haiti.” New York Times, June 21, 1987.

- "The Fall of the Prophet.” New York Review of Books, December 2, 1993.

- "The Struggle for a Democratic Haiti.” New York Times, June 21, 1987. 
Daumerie, Beatrice and Hardee, Karen. "The Effects of a Very Young Age Structure on Haiti: Country Case Study." Population Action International, The Shape of Things to Come Series, 5, http://populationaction.org/wpcontent/uploads/2011/12/SOTC_Haiti.pdf.

Davison, Phil. "Marc Louis Bazin: Former Haitian Prime Minister and World Bank Economist." Independent, July 29, 2010.

"Day of Mourning Held," Havana Radio Reloj Network [English Translation], July 3, 1987, Foreign Broadcast Information Service (FBIS) Daily Reports, Latin America, July 6, 1987.

"Deaths Reportedly High," Madrid EFE [English Translation], July 26, 1987, Foreign Broadcast Information Service (FBIS) Daily Reports, Latin America, July 27, 1987.

"'Death Squad' Scored," Port-au-Prince Radio Soleil Network [English Translation], May 12, 1988, Foreign Broadcast Information Service (FBIS) Daily Reports, Latin America, May 16, 1988.

"Decentralized Project Coordination Agency Formed," Port-au-Prince Radio Nationale [English Translation], July 15, 1988, Foreign Broadcast Information Service (FBIS) Daily Reports, Latin America, July 18, 1988.

Decker, Jonathan P. "US Investors Hesitate to Reopen Former Business Links With Haiti.” Christian Science Monitor, December 23, 1994.

"Decree Dissolves Parliament," Paris AFP [English Translation], June 20, 1988, Foreign Broadcast Information Service (FBIS) Daily Reports, Latin America, June 21, 1988.

"Decree Reinstates Entry Visas for Haitians," Port-au-Prince Radio Nationale [English Translation], January 20, 1990, Foreign Broadcast Information Service (FBIS) Daily Reports, Latin America, January 23, 1990.

"Dejoie on Call for Opposition Candidate," Paris AFP [English Translation], December 28, 1987, Foreign Broadcast Information Service (FBIS) Daily Reports, Latin America, December 28, 1987.

"Dejoie Statement," Bridgetown CANA [English Translation], January 6, 1988, Foreign Broadcast Information Service (FBIS) Daily Reports, Latin America, January 11, 1988. 
"Democratic Movements Congress Adjourns," Paris AFP [English Translation], February 2, 1987, Foreign Broadcast Information Service (FBIS) Daily Reports, Latin America, February 2, 1987.

"Demonstrators Call for Civilian Government," Bridgetown CANA [English Translation], March 24, 1986, Foreign Broadcast Information Service (FBIS) Daily Reports, Latin America, March 25, 1986.

"Demonstrators Demand Elections," Madrid EFE [English Translation], February 13, 1986, Foreign Broadcast Information Service (FBIS) Daily Reports, Latin America, February 13, 1986.

"Dessalines Soldiers Interviewed," Port-au-Prince Radio Soleil Network [English Translation], June 15, 1988, Foreign Broadcast Information Service (FBIS) Daily Reports, Latin America, June 16, 1988.

"Desulme Calls for Suspension of Hostilities," Port-au-Prince Radio Metropole [English Translation], January 29, 1988, Foreign Broadcast Information Service (FBIS) Daily Reports, Latin America, February 1, 1988.

DeGraff, Michel. "Language Behavior." Boston.com. June 16, 2010, Accessed July 12, 2016,http://www.boston.com/bostonglobe/editorial_opinion/oped/articles/2010/06 /16/language_barrier_in_haiti/.

"Democratic Front Suspends Strike; Climate 'Tense,"' Madrid EFE [English Translation], August 3, 1987, Foreign Broadcast Information Service (FBIS) Daily Reports, Latin America, August 4, 1987.

"Democratic Unity Attempts to Eliminate Division," Port-au-Prince Domestic Service [English Translation], July 14, 1987, Foreign Broadcast Information Service (FBIS) Daily Reports, July 15, 1987.

"Democratic Unity Denounces Actions," Port-au-Prince Radio Soleil Network [English Translation], September 18, 1989, Foreign Broadcast Information Service (FBIS) Daily Reports, Latin America, September 20, 1989.

"Democratic Unity Group Marks Anniversary," Port-au-Prince Radio Nationale [English Translation], March 22, 1988, Foreign Broadcast Information Service (FBIS) Daily Reports, Latin America, March 23, 1988.

"Demonstrators Protest Two Minister Appointments," Madrid EFE [English Translation], February 11, 1986, Foreign Broadcast Information Service (FBIS) Daily Reports, Latin America, February 11, 1986. 
"Demonstrators Seek Removal of President Avril," Port-au-Prince Radio Metropole [English Translation], October 11, 1989, Foreign Broadcast Information Service (FBIS) Daily Reports, Latin America, October 16, 1989.

"De Ronceray and Lafontant Form Alliance" Port-au-Prince Radio Lumiere Network [English Translation], December 14, 1990, Foreign Broadcast Information Service (FBIS) Daily Reports, Latin America, December 17, 1990.

"De Ronceray Comments on Moynihan Proposal," Port-au-Prince Radio National [English Translation], January 7, 1988, Foreign Broadcast Information Service (FBIS) Daily Reports, Latin America, January 12, 1988.

"Destruction Detailed," Port-au-Prince Radio Metropole [English Translation], January 8, 1991, Foreign Broadcast Information Service (FBIS) Daily Reports, Latin America, January 9, 1991.

"Details of Proposed Alternative to Avril Outlined," Port-au-Prince Radio Antilles Internationales [English Translation], March 8, 1990, Foreign Broadcast Information Service (FBIS) Daily Reports, Latin America, March 9, 1990.

Dewind, Josh, \& Kinley, David H. Aiding Migration: The Impact of International Development Assistance on Haiti. Boulder: Westview Press, 1988.

Dimmett, Deborah Lynn. "Haiti's Urban Poor Responds to Socio-Political and SocioCultural Conflicts: A Case Study of the Grande Ravine Community Human Rights Council," Ph.D. Dissertation, University of Arizona, 2010, Proquest Dissertations Publishing (3408334).

"Discharged Military Officers Reinstated, Promoted," Port-au-Prince Radio Metropole [English Translation], February 14, 1991, Foreign Broadcast Information Service (FBIS) Daily Reports, Latin America, February 19, 1991.

"Dissident Demands Duvalier Extradition," Paris AFP [English Translation], February 7, 1986, Foreign Broadcast Information Service (FBIS) Daily Reports, Latin America, February 11, 1986.

"Diverse Reaction to Proposed Election Calendar," Port-au-Prince Radio Metropole [English Translation], September 26, 1989, Foreign Broadcast Information Service (FBIS) Daily Reports, Latin America, September 29, 1989.

Dodson, Michael. "Liberation Theology and Christian Radicalism in Contemporary Latin America. Journal of Latin American Studies 11, no. 1 (May 1979), 203-222.

Doorenspleet, Renske. "Reassessing the Three Waves of Democratization." World Politics 52, no. 3 (April 2000): 384-406. 
Dubois, Laurent. Avengers of the New World: The Story of the Haitian Revolution.

Cambridge, Mass: Belknap Press of Harvard University Press, 2004.

- Haiti: The Aftershocks of History. New York: Metropolitan Books, 2012.

Dupuy, Alex. "Conceptualizing the Duvalier Dictatorship." Latin American Perspectives 15, no. 4 (1988): 105-114.

- Haiti in the New World Order: The Limits of the Democratic Revolution. Boulder, Colorado: Westview Press, 1997.

- Haiti in the World Economy: Class, Race, and Underdevelopment Since 1700. Boulder, Colorado: Westview, 1989.

Dupuy, Alex. The Prophet and Power. Lanham: Rowman \& Littlefield Publishers, 2007.

- $\quad$ Toussaint-Louverture and the Haitian Revolution: A Reassessment of C.L.R. James's Interpretation," in C.L.R. James: His Intellectual Legacies. Amherst: University of Massachusetts Press, 1995.

"Duvalier Government Reportedly Wins Referendum," Madrid EFE [English Translation], July 24, 1985, Foreign Broadcast Information Service (FBIS) Daily Reports, Latin America, July 25, 1985.

"Duvalier Leaves; Possible Successors Mentioned," Paris AFP [English Translation], February 7, 1986, Foreign Broadcast Information Service (FBIS) Daily Reports, Latin America, February 7, 1986.

"Duvalier Wins 'Political Structure' Referendum," Hamburg DPA [English Translation], July 26, 1985, Foreign Broadcast Information Service (FBIS) Daily Reports, Latin America, July 30, 1985.

"Education Minister Calls for Duvalier Probe," Bridgetown CANA [English Translation], February 18, 1986, Foreign Broadcast Information Service (FBIS) Daily Reports, Latin America, February 20, 1986.

"Electoral Campaign Officially Opens 22 Dec," Port-au-Prince Radio Metropole [English Translation], December 23, 1987, Foreign Broadcast Information Service (FBIS) Daily Reports, Latin America, December 24, 1987.

"Electoral Council Refuses to Step Down," Hamburg DPA [English Translation], June 25, 1987, Foreign Broadcast Information Service (FBIS) Daily Reports, Latin America, June 30, 1987. 
"Electoral Timetable Announced," Paris AFP [English Translation], June 8, 1986, Foreign Broadcast Information Service (FBIS) Daily Reports, Latin America, June 9, 1986.

"Emergency Projects Detailed," Port-au-Prince Radio Nationale [English Translation], July 21, 1988, Foreign Broadcast Information Service (FBIS) Daily Reports, Latin America, July 22, 1988.

"Enlisted Men Appoint Avril New Leader," Port-au-Prince Radio Nationale [English Translation], September 18, 1988, Foreign Broadcast Information Service (FBIS) Daily Reports, Latin America, September 19, 1988.

"Enlisted Men Arrest Suspect in Athis Murder Case," Port-au-Prince Radio Soleil Network [English Translation], September 29, 1988, Foreign Broadcast Information Service (FBIS) Daily Reports, Latin America, October 3, 1988.

Evans, Robert. "The Heir Has His Work Cut Out For Him: Haiti." New York Times, May 2, 1971.

"Explains Power Seizure," Port-au-Prince Radio Nationale [English Translation], June 20, 1988, Foreign Broadcast Information Service (FBIS) Daily Reports, Latin America, June 21, 1988.

"FADH Dismisses 7; Security Situation Viewed," Port-au-Prince Radio Soleil Network [English Translation], March 21, 1990, Foreign Broadcast Information Service (FBIS) Daily Reports, Latin America, March 22, 1990.

Falleti, Tulia G. "Theory-Guided Process-Tracing in Comparative Politics: Something Old, Something New." Newsletter of the Organized Section in Comparative Politics of the American Political Science Association, 2006.

"Father Aristide Holds News Conference," Port-au-Prince Radio Metropole [English Translation], September 7, 1990, Foreign Broadcast Information Service (FBIS) Daily Reports, Latin America, September 11, 1990.

"Father Aristide Calls for General Consensus," Port-au-Prince Radio Metropole [English Translation], February 21, 1990, Foreign Broadcast Information Service (FBIS) Daily Reports, Latin America, February 21, 1990.

"Father Aristide Message Urges 'Cleanup,"' Port-au-Prince Radio Soleil Network [English Translation], October 5, 1988, Foreign Broadcast Information Service (FBIS) Daily Reports, Latin America, October 6, 1988. 
"Father Aristide on Church 'Silence' After Coup," Port-au-Prince Radio Antilles Internationales [English Translation], June 30, 1988, Foreign Broadcast Information Service (FBIS) Daily Reports, Latin America, July 5, 1988.

"Father Aristide Urges Unity During Elections," Port-au-Prince Radio Haiti-Inter [English Translation], Foreign Broadcast Information Service (FBIS) Daily Reports, Latin America, October 12, 1990.

Fatton, Robert. The Roots of Haitian Despotism. Boulder: Lynne Rienner Publishers, 2007.

- Haiti's Predatory Republic: The Unending Transition to Democracy. Boulder, Colorodo: Lynne Rienner Publishers, 2002.

Farmer, Paul. The Uses of Haiti. Monroe, Me.: Common Courage Press, 1994.

Ferguson, James. Papa Doc, Baby Doc: Haiti and the Duvaliers. Oxford: B. Blackwell, 1988.

Fick, Carolyn E. The Making of Haiti: The Saint Domingue Revolution From Below. Knoxville : University of Tennessee Press, 1990.

- "The Saint-Domingue Slave Revolution and the Unfolding of Independence, 1791-1804," in The World of the Haitian Revolution. Bloomington: Indiana University Press, 2009.

"Finance Minister Comments on Free Zone Project," Port-au-Prince Radio Soleil Network [English Translation], August 2, 1989, Foreign Broadcast Information Service (FBIS) Daily Reports, Latin America, August 4, 1989.

Fontaine, Pierre-Michel. "Language, Society, and Development: Dialectic of French and Creole Use in Haiti." Latin American Perspectives 8, no. 1 (1981): 28-46.

"Foreigners Barred from National Election Board," Bonaire Trans World Radio [English Translation], June 25, 1987, Foreign Broadcast Information Service (FBIS) Daily Reports, Latin America, June 26, 1987.

"Former Deputy on Creation of 'Club Fraternite,"' Port-au-Prince Radio Soleil Network [English Translation], September 5, 1988, Foreign Broadcast Information Service (FBIS) Daily Reports, Latin America, September 9, 1988.

Forsythe, David P. and Rieffer, Barbara Ann J. "US Foreign Policy and Enlarging the Democratic Community." Human Rights Quarterly 22, no. 4 (November 2000): 988-1010. 
Fowler, Carolyn. "The Rise and Fall of Haiti's Press." The Christian Science Monitor, February 6, 1981.

Freeman, Bryant C. "Tèt Kole Ti Peyizan Ayisyen: The Rural Police." Occasional Paper 18 (1998): v, Institute of Haitian Studies University of Kansas, https://kuscholarworks.ku.edu/bitstream/handle/1808/10909/ihsku_opn018_1998. pdf? sequence $=1$.

French, Howard W. "A Duvalier Ally and a Foe Seek Election in Haiti, Raising Fears of Violence." New York Times, November 5, 1990.

- "A Duvalier Ally and a Foe Seek Election in Haiti, Raising Fears of Violence." New York Times, November 5, 1990.

- "After 6 Months of Changes, Haiti is Surprised by its Leaders," New York Times, August 4, 1991.

- "A Priest to the Very Poor at the Pinnacle in Haiti: Jean-Bertrand Aristide." New York Times, December 19, 1990.

- $\quad$ "Attack on Priest Called Haiti Catalyst." New York Times, September 24, 1988.

- "Envoys Arrive in Haiti to Seek an End to Coup." New York Times, October 5, 1991.

- $\quad$ "Front-Running Priest a Shock to Haiti. New York Times, December 13, 1990.

- "Haitians' Lament: Anemic Opposition." New York Times, January 20, 1991.

- "Haiti, Easing Uncertainty, Plans Elections Dec. 16," New York Times, September 30, 1990.

- "Haiti Leader Faces Task of Controlling Military." New York Times, December 20, 1990.

- "Haiti's Hope is Hostage to Its Army," New York Times, April 9, 1989.

- $\quad$ "Haiti's New Leader Takes on the Army," New York Times, February 9, 1991.

- "Haiti's Press Holds Its Critical Tongue." New York Times, January 29, 1991.

- "Haiti's Victors Working to Soothe Fears," New York Times, January 11, 1991.

- "Haiti Turnout is Sparse in Legislative Elections." New York Times, January 21, 1991. 
- "Poor in Haiti Back Election of Ex-Priest." New York Times, December 15, 1990.

- "Rights Groups Fault General for Haiti Abuses," New York Times, September 17, 1989.

- $\quad$ "Soldiers Draw the Line in Haiti," New York Times, September 25, 1988.

- "The World: New Leader of Haitians Offers U.S. a Wary Hand." New York Times, December 23, 1990.

- "Troops, Storming Palace, Capture Plotters and Free President." New York Times, January 8, 1991.

- "Voodoo Politics: The Rainy Season Haiti Since Duvalier. By Amy Wilentz." New York Times, June 25, 1989.

Friedman, Thomas L. "The O.A.S. Agrees to Isolate Chiefs of Haitian Junta." New York Times, October 3, 1991.

"Further on Cabinet," Paris AFP [English Translation], June 20, 1988, Foreign Broadcast Information Service (FBIS) Daily Reports, Latin America, June 21, 1988.

"Father Aristide on Church 'Silence' After Coup," Port-au-Prince Radio Antilles Internationales [English Translation], June 30, 1988, Foreign Broadcast Information Service (FBIS) Daily Reports, Latin America, July 5, 1988.

"Further Harassment Suffered by Journalists," Port-au-Prince Radio Soleil Network [English Translation], January 19, 1990, Foreign Broadcast Information Service (FBIS) Daily Reports, Latin America, January 23, 1990.

"Further on Damages Throughout Port-au-Prince," Port-au-Prince Radio Cacique [English Translation], January 8, 1991, Foreign Broadcast Information Service (FBIS) Daily Reports, Latin America, January 10, 1991.

"Further on Demonstrations," Hamburg DPA [English Translation], July 30, 1987, Foreign Broadcast Information Service (FBIS) Daily Reports, Latin America, July 31, 1987.

"Further on Dismissals of Workers at Flour Mill," Port-au-Prince Radio Haiti-Inter [English Translation], June 23, 1988, Foreign Broadcast Information Service (FBIS) Daily Reports, Latin America, June 24, 1988.

"Further on Labor Conflict at Garment Factory," Port-au-Prince Radio Haiti-Inter [English Translation], July 22, 1988, Foreign Broadcast Information Service (FBIS) Daily Reports, Latin America, July 27, 1988. 
"Further on Labor, Land Problems Facing Peasants," Port-au-Prince Radio AntillesInternationales [English Translation], April 4, 1988, Foreign Broadcast Information Service (FBIS) Daily Reports, Latin America, April 7, 1988.

Gaffield, Julia. "I Have Avenged America," Haiti and the Atlantic World (blog), August 2, 2013, http://haitidoi.com/2013/08/02/i-have-avenged-america/.

Geggus, David. Haitian Revolutionary Studies. Bloomington, IN: Indiana University Press, 2002.

"General Avril Returns from Taiwan 15 January," Port-au-Prince Radio Soleil Network [English Translation], January 16, 1990, Foreign Broadcast Information Service (FBIS) Daily Reports, Latin America, January 17, 1990.

"General Strike Paralyzes Port-au-Prince," Port-au-Prince Radio Metropole [English Translation], September 27, 1989, Foreign Broadcast Information Service (FBIS) Daily Reports, Latin America, September 29, 1989.

"General Strike Under Way; Streets Heavily Guarded," Madrid EFE [English Translation], June 22, 1987, Foreign Broadcast Information Service (FBIS) Daily Reports, Latin America, June 23, 1987.

"Gen Namphy Announces Elections for 1987," Hamburg DPA [English Translation], June 8, 1986, Foreign Broadcast Information Service (FBIS) Daily Reports, Latin America, June 9, 1986.

Girard, Philippe. Clinton in Haiti. New York: Palgrave Macmillan, 2004.

Goff, Stan. "Class and Complexity in Haiti." Feral Scholar, http://www.feralscholar.org/blog/index.php/2005/04/26/comparing-coups-haitivenezuela-part-2/.

"Gonaives Supports Enlisted Men," Port-au-Prince Radio Soleil Network [English Translation], September 20, 1988, Foreign Broadcast Information Service (FBIS) Daily Reports, Latin America, September 21, 1988.

Gonzales, Johnhenry. "The War on Sugar: Forced Labor, Commodity Production and the Origins of the Haitian Peasantry, 1791-1843," Ph.D. Dissertation, University of Chicago, Illinois, 2012, ProQuest Dissertations Publishing (3526305).

"Gourgue Explains Reasons for Resignation," Paris AFP [English Translation], March 21, 1986, Foreign Broadcast Information Service (FBIS) Daily Reports, Latin America March 24, 1986. 
"Government Announces Reforms in Justice System," Port-au-Prince Radio Soleil [English Translation], March 14, 1991, Foreign Broadcast Information Service (FBIS) Daily Reports, Latin America, March 15, 1991.

"Government Authorizes CATH to Resume Activities," Paris AFP [English Translation], July 6, 1987, Foreign Broadcast Information Service (FBIS) Daily Reports, Latin America, July 7, 1987.

"Government Declares Martial Law for 30 Days," Port-au-Prince Radio Nationale [English Translation], January 20, 1990, Foreign Broadcast Information Service (FBIS) Daily Reports, Latin America, January 23, 1990.

"Government Predicts Duvalier Referendum Triumph," Bridgetown CANA [English Translation], July 23, 1985, Foreign Broadcast Information Service (FBIS) Daily Reports, Latin America, July 24, 1985.

"Government Refuses Comment on U.S. Indictment," Port-au-Prince Radio Soleil Network [English Translation], March 11, 1988, Foreign Broadcast Information Service (FBIS) Daily Reports, Latin America, March 14, 1988.

"Government Takes Steps for Free, Fair Referendum," Bonaire Trans World Radio [English Translation], March 18, 1987, Foreign Broadcast Information Service (FBIS) Daily Reports, Latin America, March 19, 1987.

"Government to Press for Duvalier's Extradition," Bridgetown CANA [English Translation], February 28, 1986, Foreign Broadcast Information Service (FBIS) Daily Reports, Latin America, March 3, 1986.

Greene, Anne. The Catholic Church in Haiti: Political and Social Change. East Lansing, Michican: Michigan State University Press, 1993.

Griffin, Clifford E. "Haiti's Democratic Challenge." Third World Quarterly 13, No. 4 (1992).

Griffin, Michael and Block, Jennie Weiss (ed.). In the Company of the Poor: Conversations with Paul Farmer and Fr. Gustavo Gutiérrez. Maryknoll, New York: Orbis Books, 2013.

"Group Marks Anniversary; Splits from KID," Port-au-Prince Radio Haiti-Inter [English Translation], August 1, 1989, Foreign Broadcast Information Service (FBIS) Daily Reports, Latin America, August 3, 1989. 
"Group of 57 Calls for Total Success of Strike," Port-au-Prince Radio Lumiere Network [English Translation], July 30, 1987, Foreign Broadcast Information Service (FBIS) Daily Reports, Latin America, July 31, 1987.

"Groups Participate in Rally," Port-au-Prince Domestic Service [English Translation], July 28, 1987, Foreign Broadcast Information Service (FBIS) Daily Reports, Latin America, July 29, 1987.

"Group Urges Dismantling of Duvalier Structures," Paris AFP [English Translation], February 17, 1986, Foreign Broadcast Information Service (FBIS) Daily Reports, Latin America February 18, 1986.

Guilhot, Nicolas. The Democracy Makers: Human Rights and the Politics of Global Order. New York: Columbia University Press, 2012.

"Gunfire, Robberies Resume at Night in the Capital," Port-au-Prince Radio Metropole [English Translation], April 19, 1988, Foreign Broadcast Information Service (FBIS) Daily Reports, Latin America, April 21, 1988.

Haggard, Stephan. "The Politics of Adjustment: Lessons From the IMF's Extended Fund Facility." International Organization 39, no. 3 (Summer 1985).

"Haitian Committee to Organize Political Group," Port-au-Prince Radio Soleil Network [English Translation], June 24, 1988, Foreign Broadcast Information Service (FBIS) Daily Reports, Latin America, June 29, 1988.

"Haitian Delegate Speaks At Parties' Conference," Managua Domestic Service [English Translation], February 11, 1986, Foreign Broadcast Information Service (FBIS) Daily Reports, Latin America, February 13, 1986.

"Haitian Democratic Front Calls Off Strike," Havana Radio Rebelde Network [English Translation], August 1, 1987, Foreign Broadcast Information Service (FBIS) Daily Reports, Latin America, August 4, 1987.

"Haitian Exiles Demand Tontons Macoutes Leave," Panama City La Prensa [English Translation], February 15, 1986, Foreign Broadcast Information Service (FBIS) Daily Reports, Latin America, February 18, 1986.

"Haitian 'Group of 57' Demands Namphy's Resignation," Havana International Service [English Translation], July 14, 1987, Foreign Broadcast Information Service (FBIS) Daily Reports, Latin America, July 16, 1987.

"Haitian Officer Charged by U.S. is Reported Dead," New York Times, November 7, 1988. 
"Haitian Opposition View," Bridgetown CANA [English Translation], January 7, 1988, Foreign Broadcast Information Service (FBIS) Daily Reports, Latin America, January 11, 1988.

"Haitian Regime 'Characterized by U.S. Domination,'" Havana International Service [English Translation], August 6, 1985, Foreign Broadcast Information Service (FBIS) Daily Reports, Latin America, August 9, 1985.

"Haitians Demand Namphy, Council Resignation," Havana International Service [English Translation], July 11, 1987, Foreign Broadcast Information Service (FBIS) Daily Reports, Latin America, July 14, 1987.

"Haiti Coalition Backs Leader's Election Plan," New York Times, February 3, 1990.

"Haiti Imposes Restrictions on Radio News Broadcasts," New York Times, January 24, 1990.

"Haiti's Choice, and Father Aristide's." New York Times. December 18, 1990.

"Haiti's Military Assumes Power After Troops Arrest the President." New York Times, October 1, 1991.

"Haiti's Regala Threatens to Repress Strike Actions," Havana Radio Reloj Network [English Translation], June 29, 1987, Foreign Broadcast Information Service (FBIS) Daily Reports, Latin America, July 1, 1987.

"Haiti's Rene Theodore on 'U.S. Maneuvering,"' Havana International Service [English Translation], February 16, 1986, Foreign Broadcast Information Service (FBIS) Daily Reports, Latin America, February 20, 1986.

"Haiti's Theodore on Junta," Havana International Service [English Translation], February 7, 1986, Foreign Broadcast Information Service (FBIS) Daily Reports, Latin America, February 11, 1986.

"Haiti Vote Could Signal Start of a New Era." The Virgin Islands Daily News, March 3, 1979.

Halliday, Fred. The Making of the Second Cold War. London: Verso, 1983.

Hallward, Peter. Damming the Flood: Haiti, Aristide, and the Politics of Containment. London; New York: Verso, 2007.

- "Option Zero in Haiti." New Left Review 27 (May-June 2004), http://newleftreview.org/II/27/peter-hallward-option-zero-in-haiti. 
"Havana Says U.S. 'Deeply Involved' in Haiti," Havana Radio Rebelde Network [English Translation], March 14, 1990, Foreign Broadcast Information Service (FBIS) Daily Reports, Latin America, march 15, 1990.

Heinl, Robert Debs and Heinl, Nancy Gordon. Written in Blood: The Story of the Haitian People, 1492-1971. Boston: Houghton Mifflin, 1978.

Heinl, Robert Debs, Heinl, Nancy Gordon, and Heinl, Michael. Written in Blood: The Story of the Haitian People, 1492-1995. Lanham: University Press of America, 1996.

"Hinche Peasants to Defy Any Eviction Attempt," Port-au-Prince Radio Soleil Network [English Translation], April 8, 1988, Foreign Broadcast Information Service (FBIS) Daily Reports, Latin America, April 11, 1988.

"Holdups by Men in Military Uniforms Reported," Port-au-Prince Radio Haiti-Inter [English Translation], April 18, 1988, Foreign Broadcast Information Service (FBIS) Daily Reports, Latin America, April 19, 1988.

"Hubert de Ronceray Reaffirms Candidacy," Port-au-Prince Radio Nationale [English Translation], December 16, 1987, Foreign Broadcast Information Service (FBIS) Daily Reports, Latin America, December 17, 1987.

Huntington, Samuel. "Democracy's Third Wave." Journal of Democracy 2, no. 2 (Spring 1991): 12-34.

"Information Minister Noel Discusses Recent Violence," Port-au-Prince Domestic Service [English Translation], July 31, 1987, Foreign Broadcast Information Service (FBIS) Daily Reports, Latin America, August 5, 1987.

"Interview with Pere Jean Bertrand Aristide, St. Jean Bosco Church," Haiti Dechoukaj Collection, Box 1, Folder 3 - Interviews, 1987, December 6, 1987.

"Interview with Theodore," Havana International Service [English Translation], March 23, 1986, Foreign Broadcast Information Service (FBIS) Daily Reports, Latin America, March 31, 1986.

Ives, Kim. "A Class Analysis of Baby Doc: Mothballed Playboy Dictator Recalled to Service." Haït Liberté 4, no. 27 (January 19-25, 2011), http://www.haitiliberte.com/archives/volume427/A\%20Class\%20Analysis\%20of\%20Baby\%20Doc.asp.

"Jamaica's Seaga Reiterates Support for Manigat," Port-au-Prince Radio Nationale [English Translation], February 2, 1988, Foreign Broadcast Information Service (FBIS) Daily Reports, Latin America, February 3, 1988. 
Jenson, Deborah. Beyond the Slave Narrative: Politics, Sex, and Manuscripts in the Haitian Revolution. Liverpool: Liverpool University Press, 2011.

- $\quad$ "Dessalines's American Proclamations of the Haitian Independence." The Journal of Haitian Studies 15, no. 1 \& 2 (2009): 72-102.

Joshi, Manoj K. "The 'Human Rights Phase' of American Foreign Policy." Social Scientist, 10, no. 6 (June 1982): 38-50.

"Justice Minister Favors Exiles' Gradual Return," Paris AFP [English Translation], February 18, 1986, Foreign Broadcast Information Service (FBIS) Daily Reports, Latin America, February 19, 1986.

"Justice Minister Protests Pierre's Departure," Bridgetown CANA [English Translation], February 25, 1986, Foreign Broadcast Information Service (FBIS) Daily Reports, Latin America, February 26, 1986.

"Justice Ministry to Prosecute Embezzling Macoutes," Port-au-Prince Radio Soleil [English Translation], March 19, 1991, Foreign Broadcast Information Service (FBIS) Daily Reports, Latin America, March 21, 1991.

Kidder, Tracy. Mountains Beyond Mountains. New York: Random House, 2003.

"KID Praises Strike, Gives Avril Deadline," Port-au-Prince Radio Soleil Network [English Translation], September 29, 1989, Foreign Broadcast Information Service (FBIS) Daily Reports, Latin America, October 3, 1989.

Knight, Alan. "Democratic and Revolutionary Traditions in Latin America." Bulletin of Latin American Research 20, no. 2 (April 2001): 147-186.

Komisar, Lucy. "A New Duvalier in Haiti?" New York Times, April 22, 1989.

Krauss, Clifford. "Haitian Victor Reportedly Ready to Soften Stands. New York Times, December 20, 1990.

- "In Policy Shift, U.S. Criticizes Haitian on Rights Abuses." New York Times, October 7, 1991.

Krouse, Richard W. "Polyarchy \& Participation: The Changing Democratic Theory of Robert Dahl." Polity 14, no. 3 (Spring 1982): 441-463.

"Labor Unrest, 'Uprooting' Spread," September 29, 1988, Foreign Broadcast Information Service (FBIS) Daily Reports. 
Lafeber, Walter. Inevitable Revolutions: The United States in Central America. New York: Norton, 1983.

- $\quad$ "The Reagan Administration and Revolutions in Central America." Political Science Quarterly 99, no. 1 (Spring, 1984), 1-25.

"La Gonave Complaints Cited," Port-au-Prince Radio Nationale [English Translation], April 5, 1988, Foreign Broadcast Information Service (FBIS) Daily Reports, Latin America, April 7, 1988.

"Lay Groups Call for Change," Port-au-Prince Radio Soleil Network [English Translation], August 9, 1988, Foreign Broadcast Information Service (FBIS) Daily Reports, Latin America, August 11, 1988.

"L. Bird - Manigat's Haiti 'Cosmetic Democracy,"' Bridgetown CANA [English Translation], June 21, 1988, Foreign Broadcast Information Service (FBIS) Daily Reports, Latin America, June 22, 1988.

"Leaders Issue Communique on Haiti Situation," Bridgetown CANA [English Translation], January 7, 1988, Foreign Broadcast Information Service (FBIS) Daily Reports, Latin America, January 11, 1988.

"Leaders Justify Coup," Paris AFP [English Translation], September 18, 1988, Foreign Broadcast Information Service (FBIS) Daily Reports, Latin America, September 19, 1988.

"Leaders Reaction Noted," Paris AFP [English Translation], September 19, 1988, Foreign Broadcast Information Service (FBIS) Daily Reports, Latin America, September 20, 1988.

"Leader Urged to Dismiss Duvalier Supporters," Hong Kong AFP [English Translation], February 20, 1986, Foreign Broadcast Information Service (FBIS) Daily Reports, Latin America, February 20, 1986.

"Legislature Amends National Constitution," Bonaire Trans World Radio [English Translation], June 7, 1985, Foreign Broadcast Information Service (FBIS) Daily Reports, Latin America, June 11, 1985.

"Leslie Manigat Officially Elected President," Paris AFP [English Translation], January 24, 1988, Foreign Broadcast Information Service (FBIS) Daily Reports, Latin America, January 25, 1988.

"Leslie Manigat to Run," Port-au-Prince Radio Metropole, December 31, 1987. 
"Letter Sent to CEH Asking for Mediation," Port-au-Prince Radio Nationale [English Translation], January 28, 1988, Foreign Broadcast Information Service (FBIS) Daily Reports, Latin America, January 29, 1988.

Levin, Andrew S. "Civil Society and Democratization in Haiti." Emory International Law Review 9, no. 2 (1995): 389-457.

Libby, Ronald T. "The United States and Jamaica: Playing the American Card," Latin American Perspectives 17, no. 1, Caribbean Crisis and Global Restructuring (Winter, 1990), 89.

"Looting Resumes, List of Demands Circulates," Bridgetown CANA [English Translation], February 11, 1986, Foreign Broadcast Information Service (FBIS) Daily Reports, Latin America, February 12, 1986.

Lundahl, Mats. Politics or Markets? Essays on Haitian Underdevelopment. London: Routledge, 2002.

Lynch, Marika. "Aristide: A Hope Reshaped." Miami Herald, February 29, 2004.

McFadyen, Deidre (ed). Haiti: Dangerous Crossroads (Boston, MA: South End Press, 1995).

"Maissade Takes Tax Stand," Port-au-Prince Radio Soleil Network [English Translation], April 6, 1988, Foreign Broadcast Information Service (FBIS) Daily Reports, Latin America, April 7, 1988.

"Major General Regala Resigns From Armed Forces," Port-au-Prince Radio Metropole [English Translation], February 10, 1988, Foreign Broadcast Information Service (FBIS) Daily Reports, February 11, 1988.

"Manhunts, Lynchings in Capital Reported," Port-au-Prince Radio Metropole [English Translation], September 20, 1988, Foreign Broadcast Information Service (FBIS) Daily Reports, Latin America, September 21, 1988.

"Manifeste Du 1er Septembre 1842," in Recueil Général Des Lois \& Actes Du Gouvernement d'Haiti, Digital Library of the Caribbean (dLOC), http://www.dloc.com/UF00074014/00004/275x?vo=2.

"Manigat: Government Needs Time, Joint Efforts," Port-au-Prince Nationale [English Translation], March 19, 1988, Foreign Broadcast Information Service (FBIS) Daily Reports, Latin America, March 23, 1988. 
"Manigat Government Said Facing 'Big Problem,'" Port-au-Prince Radio Soleil Network [English Translation], May 23, 1988, Foreign Broadcast Information Service (FBIS) Daily Reports, Latin America, May 24, 1988.

"Manigat Interviewed on U.S. Relations," Port-au-Prince Le Petit Samedi Soir [English Translation], January 6-29, 1988, Foreign Broadcast Information Service (FBIS) Daily Reports, Latin America, February 4, 1988.

"Manigat Introduces Rural Property Plan," Port-au-Prince Radio Nationale [English Translation], May 1, 1988, Foreign Broadcast Information Service (FBIS) Daily Reports, Latin America, May 3, 1988.

"Manigat Issues Communique," Port-au-Prince Radio Metropole [English Translation], June 15, 1988, Foreign Broadcast Information Service (FBIS) Daily Reports, Latin America, June 16, 1988.

"Manigat Issues Decree," Port-au-Prince Radio Nationale [English Translation], June 18, 1988, Foreign Broadcast Information Service (FBIS) Daily Reports, Latin America, June 20, 1988.

"Manigat on Duvalierism, Reform, Military Role," Port-au-Prince Radio Metropole [English Translation], February 3, 1988, Foreign Broadcast Information Service (FBIS) Daily Reports, Latin America, February 5, 1988.

"Manigat on Insecurity Issue, Army Situation," Port-au-Prince Radio Nationale [English Translation], June 16, 1988, Foreign Broadcast Information Service (FBIS) Daily Reports, Latin America, June 20, 1988.

"Manigat on National Reconciliation Policy," Port-au-Prince Le Progressiste Haitien [English Translation], April 28, 1988, Foreign Broadcast Information Service (FBIS) Daily Reports, Latin America, May 2, 1988.

"Manigat on Private Sector," Port-au-Prince Radio Metropole [English Translation], January 28, 1988, Foreign Broadcast Information Service (FBIS) Daily Reports, Latin America, January 29, 1988.

"Manigat Speaks on Economic Plans, Criticism," Port-au-Prince Domestic Service [English Translation], March 5, 1988, Foreign Broadcast Information Service (FBIS) Daily Reports, Latin America, March 10, 1988.

"Manigat Supporters Killed by 'Armed Civilians,"' Port-au-Prince Radio Soleil Network [English Translation], November 20, 1989, Foreign Broadcast Information Service (FBIS) Daily Reports, Latin America, November 22, 1989. 
"Manigat Talks With Businessmen on Economy," Port-au-Prince Radio Nationale [English Translation], January 28, 1988, Foreign Broadcast Information Service (FBIS) Daily Reports, Latin America, January 29, 1988.

"Manigat to Address People Via Radio, TV Casts," Port-au-Prince Radio Nationale [English Translation], February 18, 1988, Foreign Broadcast Information Service (FBIS) Daily Reports, February 19, 1988.

"Manley Gives Views," Bridgetown CANA [English Translation], January 13, 1988, Foreign Broadcast Information Service (FBIS) Daily Reports, Latin America, January 14, 1988.

Maternowska, Catherine M. Reproducing Inequalities: Poverty and the Politics of Population in Haiti. New Brunswick, N.J.: Rutgers University Press, 2006.

McFadyen, Deidre (ed). Haiti: Dangerous Crossroads. Boston, MA: South End Press, 1995.

"Measures to Fight Contraband Smuggling Praised," Port-au-Prince Radio Nationale [English Translation], April 1, 1988, Foreign Broadcast Information Service (FBIS) Daily Reports, Latin America, April 25, 1988.

"Meeting Called," Port-au-Prince Domestic Service [English Translation], July 9, 1987, Foreign Broadcast Information Service (FBIS) Daily Reports, Latin America, July 10, 1987.

"Meeting on Haiti Begins; Haitians Attend," Kingston Domestic Service, January 6, 1988, Foreign Broadcast Information Service (FBIS) Daily Reports, Latin America, January 7, 1988.

"MIDH's Bazin: Dialogue 'Absolute Necessity,'" Port-au-Prince Radio Nationale [English Translation], July 29, 1988, Foreign Broadcast Information Service (FBIS) Daily Reports, Latin America, August 2, 1988.

"MIDH's Bazin Interviewed by Government Paper," Port-au-Prince Radio Metropole [English Translation], April 9, 1990, Foreign Broadcast Information Service (FBIS) Daily Reports, Latin America, April 10, 1990.

"Military Government Announces Job Program," Port-au-Prince Radio Metropole [English Translation], July 20, 1988, Foreign Broadcast Information Service (FBIS) Daily Reports, Latin America, July 22, 1988.

"Military Presence Halts Petit Goave Disturbance," Port-au-Prince Radio Soleil Network [English Translation], October 16, 1989, Foreign Broadcast Information Service (FBIS) Daily Reports, Latin America, October 18, 1989. 
"Mill Workers Return; More Labor Conflicts Noted," Port-au-Prince Radio Soleil Network [English Translation], April 14, 1988, Foreign Broadcast Information Service (FBIS) Daily Reports, April 15, 1988.

"Ministerial Commission to Investigate Massacres," Port-au-Prince Le Nouvelliste [English Translation], February 27, 1991, Foreign Broadcast Information Service (FBIS) Daily Reports, Latin America, February 28, 1991.

"Minister Orders Arrest of Massacre Participants," Port-au-Prince Radio Soleil [English Translation], March 14, 1991, Foreign Broadcast Information Service (FBIS) Daily Reports, Latin America, March 15, 1991.

"Ministry of Information on New Commissions," Port-au-Prince Radio Nationale [English Translation], July 1, 1988, Foreign Broadcast Information Service (FBIS) Daily Reports, Latin America, July 5, 1988.

"Moderate Parties Sign 'Joint Action Pact,"' Paris AFP [English Translation], December 24, 1986, Foreign Broadcast Information Service (FBIS) Daily Reports, January 8, 1987.

Montas-Dominique, Michele. "The Role of the Press in Helping Create the Conditions of Democracy to Develop in Haiti." University of Miami Law Review 56, (20012002): 397-404.

"MOP's Gerard Philippe Auguste to Run," Port-au-Prince Radio Nationale Creole [English Translation], January 5, 1988, Foreign Broadcast Information Service (FBIS) Daily Reports, Latin America, January 7, 1988.

"MOP Youth Not to Participate in Elections," Port-au-Prince Radio Metropole [English Translation], January 8, 1988, Foreign Broadcast Information Service (FBIS) Daily Reports, Latin America, January 11, 1988.

"More Reportage on 28 Feb ANDP Statement," Port-au-Prince Radio Metropole [English Translation], March 1, 1990, Foreign Broadcast Information Service (FBIS) Daily Reports, Latin America, March 5, 1990.

"MPP Proposes Lowering State Employee Salaries," Port-au-Prince Radio Soleil Network [English Translation], February 15, 1991, Foreign Broadcast Information Service (FBIS) Daily Reports, Latin America, February 19, 1991.

"Namphy Addresses Nation," Port-au-Prince Domestic Service [English Translation], June 20, 1988, Foreign Broadcast Information Service (FBIS) Daily Reports, Latin America, June 21, 1988. 
"Namphy Address on New 'Democratic Charter,"' Port-au-Prince Domestic Service [English Translation], July 8, 1988, Foreign Broadcast Information Service (FBIS) Daily Reports, Latin America, July 11, 1988.

"Namphy Blames 'Agitators,"' Buenos Aires Reuter [English Translation], April 28, 1986, Foreign Broadcast Information Service (FBIS) Daily Reports, Latin America, April 28, 1986.

"Namphy Calls for 'Historic Commitment,"' Paris AFP [English Translation], January 1, 1988, Foreign Broadcast Information Service (FBIS) Daily Reports, Latin America, January 4, 1988.

"Namphy Calls for 'Trust,"' Paris AFP [English Translation], June 20, 1988, Foreign Broadcast Information Service (FBIS) Daily Reports, Latin America, June 20, 1988.

"Namphy Discusses Transition to Democracy," Namphy Discusses Transition to Democracy [English Translation], February 7, 1987, Foreign Broadcast Information Service (FBIS) Daily Reports, Latin America, February 12, 1987.

"Namphy on Coup Reasons, Elections, Army Role," Paris Liberation [English Translation], June 27, 1988, Foreign Broadcast Information Service (FBIS) Daily Reports, Latin America, June 30, 1988.

"Namphy Promises Direct Presidential Elections," Madrid EFE [English Translation], February 10, 1986, Foreign Broadcast Information Service (FBIS) Daily Reports, Latin America, February 11, 1986.

"Namphy Reaffirms Military Commitment to People," Port-au-Prince Domestic Service [English Translation], July 17, 1987, Foreign Broadcast Information Service (FBIS) Daily Reports, Latin America, July 20, 1987.

"Namphy Reproaches CEP," Paris AFP [English Translation], November 30, 1987, Foreign Broadcast Information Service (FBIS) Daily Reports, Latin America, November 30, 1987.

"Namphy Says Country Not Ready for Elections," July 27, 1988, Foreign Broadcast Information Service (FBIS) Daily Reports.

"Namphy Warns of Civil War," Bridgetown CANA [English Translation], June 5, 1986, Foreign Broadcast Information Service (FBIS) Daily Reports, Latin America, June 6, 1986.

National Coalition for Haitian Refugees, Americas Watch, "Haiti 1987 Election Watch: A Democracy Through Terror," Haitian Dechoukaj Collection, Box 1, Folder 8. 
National Coalition for Haitian Refugees, "The Political and Human Rights Crisis in Haiti: Terror and the Elections of 1987," Haitian Dechoukaj Collection, Box 1, Folder 8.

"National Governing Council Dissolves CATH," Hilversum International Service [English Translation], June 24, 1987, Foreign Broadcast Information Service (FBIS) Daily Reports, Latin America, June 24, 1987.

"New Government Security Plan Outlined," Port-au-Prince Radio Metropole [English Translation], May 6, 1988, Foreign Broadcast Information Service (FBIS) Daily Reports, Latin America, May 9, 1988.

"New Government to Disband 'Tontons Macoutes,"' Hong Kong AFP [English Translation], February 10, 1986, Foreign Broadcast Information Service (FBIS) Daily Reports, Latin America, February 10, 1986.

"New Party Urges People to Overthrow Government," Port-au-Prince Radio Metropole [English Translation], August 30, 1988, Foreign Broadcast Information Service (FBIS) Daily Reports, Latin America, August 31, 1988.

"New President Calls for National Reconciliation," Paris AFP [English Translation], February 7, 1988, Foreign Broadcast Information Service (FBIS) Daily Reports, Latin America, February 8, 1988.

"New Provisional Electoral Council Sworn In," Port-au-Prince Radio Nationale [English Translation], December 14, 1987, Foreign Broadcast Information Service (FBIS) Daily Reports, Latin America, December 15, 1987.

"News Media 'Targeted' by Army," Paris AFP [English Translation], August 1, 1987, Foreign Broadcast Information Service (FBIS) Daily Reports, Latin America, August 5, 1987.

"New Workers, Peasants Front Party Created," Port-au-Prince Radio Soleil Network [English Translation], January 6, 1988, Foreign Broadcast Information Service (FBIS) Daily Reports, Latin America, January 7, 1988.

Neyfakh, Leon. "The Power of Creole." Boston.com, July 24, 2011, Accessed July 12, 2016,http://www.boston.com/news/education/k_12/articles/2011/07/24/the_power _of_creole/?page=full.

Nicholls, David. From Dessalines to Duvalier: Race, Colour and National Independence in Haiti. Cambridge: Cambridge University Press, 1979.

- "Haiti, the Rise and Fall of Duvalierism." Third World Quarterly 8, no. 4 (1986): 1239-1252. 
- "Rural Protest and Peasant Revolt, 1804-1879," in Haitian History: New Perspectives. New York: Routledge, 2013.

"No Haitian Elections, Military Ruler Declares," New York Times, June 28, 1988.

Norton, Graham. "Review: The Haiti File," The World Today 42, no. 6 (June 1986).

"Odlum Criticizes CDU Role in Haitian Situation," Bridgetown CANA [English Translation], January 8, 1988, Foreign Broadcast Information Service (FBIS) Daily Reports, Latin America, January 14, 1988.

O'Donnell, Guillermo, and Schmitter, Philippe C. Transitions from Authoritarian Rule: Tentative Conclusions about Uncertain Democracies. Baltimore: John Hopkins University Press, 1986.

"Opposition Calls for Strike, Council Resignation," Bonaire Trans World Radio [English Translation], April 28, 1986, Foreign Broadcast Information Service (FBIS) Daily Reports, Latin America, May 1, 1986.

"Opposition Calls for Strike to Resume 15 July," Port-au-Prince Domestic Service [English Translation], July 13, 1987, Foreign Broadcast Information Service (FBIS) Daily Reports, July 14, 1987.

"Opposition Coalition Seeks Provisional Government," Paris AFP [English Translation], July 8, 1987, Foreign Broadcast Information Service (FBIS) Daily Reports, Latin America, July 8, 1987.

"Opposition Comments," Port-au-Prince Radio Metropole [English Translation], February 9, 1988, Foreign Broadcast Information Service (FBIS) Daily Reports, Latin America, February 11, 1988.

"Opposition Gives Namphy Resignation Deadline," Paris AFP [English Translation], July 9, 1987, Foreign Broadcast Information Service (FBIS) Daily Reports, July 9, 1987.

"Opposition in Exile Forms Government," Madrid EFE [English Translation], February 9, 1986, Foreign Broadcast Information Service (FBIS) Daily Reports, Latin America, February 11, 1986.

"Opposition Leader Brun Expelled from Country," Paris AFP [English Translation], January 22, 1990, Foreign Broadcast Information Service (FBIS) Daily Reports, Latin America, January 22, 1990. 
"Opposition Leader Louis E. Athis Killed 2 Aug," Paris AFP [English Translation], August 3, 1987, Foreign Broadcast Information Service (FBIS) Daily Reports, Latin America, August 4, 1987.

"Opposition Leaders Detained, 'Severely Beaten,"' Paris AFP [English Translation], January 20, 1990, Foreign Broadcast Information Service (FBIS) Daily Reports, Latin America, January 22, 1990.

"Opposition Unites Around 'Common Alternative,'" Port-au-Prince Radio Antilles Internationales [English Translation], March 5, 1990, Foreign Broadcast Information Service (FBIS) Daily Reports, Latin America, March 6, 1990.

Orenstein, Catherine. "An Interview with Ben Dupuy, Aristide's Ambassador-at-Large, 1993," in A Haiti Anthology: Libète. Princeton, NJ: Markus Wiener Publishers, 1999.

"Organizations Scheduled to Protest Inflation," Port-au-Prince Radio Soleil Network [English Translation], September 15, 1989, Foreign Broadcast Information Service (FBIS) Daily Reports, Latin America, September 18, 1989.

"Paper Views Various Reactions to CNG Decision," Port-au-Prince Le Nouvelliste [English Translation], July 4-5, 1987, Foreign Broadcast Information Service (FBIS) Daily Reports, Latin America, July 7, 1987.

"Part 1 of Aristide Interview of Current Juncture," Port-au-Prince Radio Metropole [English Translation], April 2, 1990, Foreign Broadcast Information Service (FBIS) Daily Reports, Latin America, April 4, 1990.

Paquin, Lyonel. The Haitians, Class and Color Politics. Brooklyn, N.Y.: Multi-Type, 1983.

"Party Founder Favors Bazin Dialogue Proposal," Port-au-Prince Radio Soleil Network [English Translation], August 5, 1988, Foreign Broadcast Information Service (FBIS) Daily Reports, Latin America, August 9, 1988.

Pastor, Robert. "Continuity and Change in U.S. Foreign Policy: Carter and Reagan on El Salvador." Journal of Policy Analysis and Management 3, no. 2 (Winter 1984): 175-190.

"PDCH Expresses Concern," Port-au-Prince Radio Soleil Network [English Translation], May 12, 1988, Foreign Broadcast Information Service (FBIS) Daily Reports, Latin America, May 16, 1988. 
"PDCH Issues Note on Organization of Elections," Port-au-Prince Radio Lumiere Network [English Translation], July 16, 1987, Foreign Broadcast Information Service (FBIS) Daily Reports, Latin America, July 20, 1987.

"PDCH Leader Blames U.S. if Country Turns Communist," Port-au-Prince Radio Antilles Internationales [English Translation], July 13, 1987, Foreign Broadcast Information Service (FBIS) Daily Reports, July 15, 1987.

"PDCH on Bazin Message, Talks with Army," Port-au-Prince Radio Soleil Network [English Translation], August 1, 1988, Foreign Broadcast Information Service (FBIS) Daily Reports, Latin America, August 2, 1988.

Pear, Robert. "A Surprising Chance for Democracy in Haiti." New York Times, October 9, 1988.

- $\quad$ "U.S. Officials Say New Haitian Rulers Are Like the Old Ones," New York Times, September 19, 1988.

- "Washington Warns Haiti on Indicted Colonel," New York Times, September 20, 1988.

"Peasant Group Protests Restrictions on Assembly," Port-au-Prince Radio Soleil Network [English Translation], August 23, 1988, Foreign Broadcast Information Service (FBIS) Daily Reports, Latin America, August 24, 1988.

"Peasant Movement Assesses Haitian Situation," Port-au-Prince Radio Soleil Network [English Translation], September 20, 1989, Foreign Broadcast Information Service (FBIS) Daily Reports, Latin America, September 21, 1989.

"Peasants Blame 'Imperialism,'" Port-an-Prince Radio Haiti-Inter [English Translation], April 19, 1991, Foreign Broadcast Information Service (FBIS) Daily Reports, Latin America, April 24, 1991.

"Peasants Protest Rents; Refuse to Pay Taxes," Port-au-Prince Radio Soleil Network [English Translation], April 5, 1988, Foreign Broadcast Information Service (FBIS) Daily Reports, Latin America, April 6, 1988.

Pellet, Gail. "Ti Legliz: Liberation Theology in Haiti." New Age Magazine, July/August 1986, http://gailpellettproductions.com/ti-legliz-liberation-theology-in-haiti/.

"'People's Court' Tries Former Officials," Port-au-Prince Radio Soleil Network [English Translation], September 29, 1988, Foreign Broadcast Information Service (FBIS) Daily Reports, Latin America, September 30, 1988. 
"Petition Seeks Ban on Recent Leaders Leaving," Port-au-Prince Radio Soleil Network [English Translation], February 6, 1991, Foreign Broadcast Information Service (FBIS) Daily Reports, Latin America, February 7, 1991.

Pezzullo, Ralph. Plunging into Haiti: Clinton, Aristide, and the Defeat of Diplomacy. Jackson: University Press of Mississippi, 2006.

"Pierre Charles Comments on U.S. AID, Elections," Mexico City NOTIMEX [English Translation], May 23, 1987, Foreign Broadcast Information Service (FBIS) Daily Reports, Latin America, May 26, 1987.

Pierre-Charles, Gerard and Low, Margaret. "The Democratic Revolution in Haiti." Latin American Perspectives 15, no. 3, (Summer 1988): 64-76.

Plummer, Brenda Gayle. Haiti and the United States: The Psychological Moment. Athens: University of Georgia Press, 1992.

"Police Chief Given Asylum at Brazilian Embassy," Paris AFP [English Translation], February 23, 1986, Foreign Broadcast Information Service (FBIS) Daily Reports, Latin America, February 24, 1986.

"Political Brigades Vow to Protect New Constitution," Paris AFP [English Translation], May 26, 1987, Foreign Broadcast Information Service (FBIS) Daily Reports, Latin America, May 28, 1987.

"Political Leaders React," Port-au-Prince Radio Metropole [English Translation], November 3, 1989, Foreign Broadcast Information Service (FBIS) Daily Reports, Latin America, November 6, 1989.

"Political Parties Call for Further Strikes," Port-au-Prince Radio Soleil Network [English Translation], November 21, 1989, Foreign Broadcast Information Service (FBIS) Daily Reports, Latin America, November 22, 1989.

"Politicians Call for 3-Day General Strike," Buenos Aires Reuter [English Translation], June 7, 1986, Foreign Broadcast Information Service (FBIS) Daily Reports, Latin America, June 9, 1986.

"Politicians on Strike, 'Foreign Interference,"' Port-au-Prince Radio Metropole [English Translation], September 28, 1989, Foreign Broadcast Information Service (FBIS) Daily Reports, Latin America, October 2, 1989.

"Poll Results Support Decision on Haiti," Bridgetown CANA [English Translation], January 29, 1988, Foreign Broadcast Information Service (FBIS) Daily Reports, Latin America, February 10, 1988. 
Popkin, Jeremy. A Concise History of the Haitian Revolution. Chichester: WileyBlackwell, 2011.

"Port-au-Prince Devastated," Port-au-Prince Radio Metropole [English Translation], January 8, 1991, Foreign Broadcast Information Service (FBIS) Daily Reports, Latin America, January 9, 1991.

Portes, Alejandro, Itzigsohn, José, and Dore-Cabral, Carlos. "Urbanization in the Caribbean Basin: Social Change During the Years of the Crisis." Latin American Research Review 29, no. 2 (1994): 3-37.

"Position Clarified," Port-au-Prince Radio Nationale [English Translation], January 8, 1988, Foreign Broadcast Information Service (FBIS) Daily Reports, Latin America, January 11, 1988.

"President Aristide's Inaugural Address 7 Feb," Port-au-Prince Radio Nationale [English Translation], February 7, 1991, Foreign Broadcast Information Service (FBIS) Daily Reports, Latin America, February 11, 1991.

"President Avril Castigates Constitution Group," Port-au-Prince Radio Soleil Network [English Translation], January 16, 1990, Foreign Broadcast Information Service (FBIS) Daily Reports, Latin America, January 19, 1990.

"President Avril Declares General Amnesty," Paris AFP [English Translation], February 8, 1990, Foreign Broadcast Information Service (FBIS) Daily Reports, Latin America, February 8, 1990.

"President Avril, 'Major Political Leaders' Meet," Port-au-Prince Radio Nationale [English Translation], September 28, 1988, Foreign Broadcast Information Service (FBIS) Daily Reports, Latin America, September 29, 1988.

"President-Elect Aristide Outlines Tasks, Goals," Mexico City NOTIMEX [English Translation], January 13, 1991, Foreign Broadcast Information Service (FBIS) Daily Reports, Latin America, January 14, 1991.

"President-Elect Holds First News Conference," Port-au-Prince Radio Metropole [English Translation], January 26, 1988, Foreign Broadcast Information Service (FBIS) Daily Reports, Latin America, January 27, 1988.

"Presidential Election Planned for Oct 90," Port-au-Prince Radio Nationale [English Translation], September 25, 1989, Foreign Broadcast Information Service (FBIS) Daily Reports, Latin America, September 26, 1989. 
"Presidential Guard Involved," Paris AFP [English Translation], September 18, 1988, Foreign Broadcast Information Service (FBIS) Daily Reports, Latin America, September 19, 1988.

"President Namphy Vows to 'Eliminate' Macoutism," Paris AFP [English Translation], November 13, 1986, Foreign Broadcast Information Service (FBIS) Daily Reports, Latin America, November 13, 1986.

"Press Comments on U.S. Company Contract, Aid," Port-au-Prince Radio Soleil Network [English Translation], August 14, 1989, Foreign Broadcast Information Service (FBIS) Daily Reports, Latin America, August 22, 1989.

"Priest on Role of Church in 'Struggle,'" Port-au-Prince Domestic Service [English Translation], August 17, 1987, Foreign Broadcast Information Service (FBIS) Daily Reports, Latin America, August 19, 1987.

"Priest Wants Strong Measures Against Macoutes," Port-au-Prince Radio Soleil Network [English Translation], March 22, 1990, Foreign Broadcast Information Service (FBIS) Daily Reports, Latin America, March 23, 1990.

"PUCH Calls for Election Postponement," Port-au-Prince Radio Metropole [English Translation], January 12, 1988, Foreign Broadcast Information Service (FBIS) Daily Reports, Latin America, January 13, 1988.

"PUCH Comments on Avril's Taiwan Trip," Port-au-Prince Radio Metropole [English Translation], January 9, 1990, Foreign Broadcast Information Service (FBIS) Daily Reports, Latin America, January 11, 1990.

"PUCH Denounces Zone Contract," Port-au-Prince Radio Nationale [English Translation], July 28, 1989, Foreign Broadcast Information Service (FBIS) Daily Reports, Latin America, July 31, 1989.

"PUCH Head on Domestic Situation, Party's Role," Budapest NEPSZABADSAG [English Translation], April 22, 1988, Foreign Broadcast Information Service (FBIS) Daily Reports, Latin America, Aprils 26, 1988.

"PUCH Leader Theodore," Port-au-Prince Radio Metropole [English Translation], June 22, 1988, Foreign Broadcast Information Service (FBIS) Daily Reports, Latin America, June 24, 1988.

"PUCH Official on Current Political Situation," Port-au-Prince Domestic Service [English Translation], July 6, 1987, Foreign Broadcast Information Service (FBIS) Daily Reports, Latin America, July 8, 1987. 
"PUCH, PDCH Leaders Issue Statements," Port-au-Prince Radio Metropole [English Translation], October 5, 1989, Foreign Broadcast Information Service (FBIS) Daily Reports, Latin America, October 11, 1989.

"PUCH Predicts Upheaval from IMF Measures," Port-au-Prince Radio Metropole [English Translation], August 24, 1989, Foreign Broadcast Information Service (FBIS) Daily Reports, Latin America, August 30, 1989.

"PUCH's Bourjolly on Anticommunist Campaign," Port-au-Prince Radio Nationale, December 10, 1987, Foreign Broadcast Information Service (FBIS) Daily Reports, Latin America, December 11, 1987.

"PUCH's Theodore Says Celestin 'Incompetent'," Port-au-Prince Radio Metropole [English Translation], March 17, 1988, Foreign Broadcast Information Service (FBIS) Daily Reports, Latin America, March 18, 1988.

"Radio Soleil on 'Wave of Insecurity' in Capital," Port-au-Prince Radio Soleil Network [English Translation], May 3, 1988, Foreign Broadcast Information Service (FBIS) Daily Reports, Latin America, May 5, 1988.

"Radio Soleil Views Meeting," Port-au-Prince Radio Soleil Network [English Translation], August 18, 1988, Foreign Broadcast Information Service (FBIS) Daily Reports, Latin America, August 23, 1988.

Ramsey, Kate. The Spirits and the Law: Vodou and Power in Haiti. Chicago: University of Chicago Press, 2011.

"Referendum on Constitution," Havana International Service [English Translation], March 29, 1987, Foreign Broadcast Information Service (FBIS) Daily Reports, Latin America, April 2, 1987.

"Removals Sought in Gonaives," Port-au-Prince Radio Metropole [English Translation], September 20, 1988, Foreign Broadcast Information Service (FBIS) Daily Reports, Latin America, September 21, 1988.

"Reports Indicate No Real Changes in Haiti," Havana International Service [English Translation], May 13, 1986, Foreign Broadcast Information Service (FBIS) Daily Reports, Latin America, May 15, 1986.

"Repression Reported," Havana International Service [English Translation], July 2, 1987, Foreign Broadcast Information Service (FBIS) Daily Reports, Latin America, July 6, 1987. 
"Repression, U.S. Dollar Discussed in Artibonite," Port-au-Prince Radio Soleil Network [English Translation], September 11, 1989, Foreign Broadcast Information Service (FBIS) Daily Reports, Latin America, September 13, 1989.

Riding, Alan. "Foreign Investments and Tourism Rise: Haitian Economy Beginning to Stir." New York Times, August 23, 1971.

Rhodes, Leara. Democracy and the Role of the Haitian Media. Lewiston: E. Mellen Press, 2001.

Robinson, William I. "Pushing Polyarchy: The US-Cuba Case and the Third World." Third World Quarterly 16, no. 4 (December 1995): 643-659.

Rosensweig, F., McGahey, C., Noth, R., Shafritz, L., and Gottert, P., A Plan for CDS to Establish a Water and Sanitation District in Cité Soleil, Haiti and Monitoring Visit Report, Activity Report No. 21, United States Agency for International Development (May 1996), retrieved from http://pdf.usaid.gov/pdf_docs/PNABY701.pdf.

Schanche, Don A. "Haitian General Ousts President: Strongman Escapes House Arrest, Seizes Palace in Hail of Gunfire," Los Angeles Times, June 20, 1988.

"Says Namphy 'Mentally Ill,"' Santo Domingo Radio Mil Network [English Translation], June 21, 1988, Foreign Broadcast Information Service (FBIS) Daily Reports, Latin America, June 22, 1988.

"Several Parties Form New Political Front," Port-au-Prince Radio Soleil Network [English Translation], June 15, 1990, Foreign Broadcast Information Service (FBIS) Daily Reports, Latin America, June 20, 1990.

Schmidt, Hans. The United States Occupation of Haiti, 1915-1934. New Brunswick, N.J.: Rutgers University Press, 1995.

Schneider, Mark L. "Human Rights Policy Under the Carter Administration." Law and Contemporary Problems 43, no. 2 (Spring 1979): 262-264.

"Schools Reopen; Students Call for Elections," Bridgetown CANA [English Translation], February 17, 1986, Foreign Broadcast Information Service (FBIS) Daily Reports, Latin America, February 18, 1986.

Schuller, Mark and Morales, Pablo (ed.). Tectonic Shifts: Haiti Since the Earthquake. Sterling, VA: Kumarian Press, 2012.

Sciolino, Elaine. "U.S. Looks to Haitian Military to Restore Elections," New York Times, December 3, 1987. 
Scott, Helen. "Haiti Under the Eagle." SocialistWorker.org (blog), January 26, 2010, http://socialistworker.org/2010/01/26/haiti-under-the-eagle.

Severo, Richard. "In Haiti, Things On the Surface Seem the Same, but Many Changes are Emerging." New York Times, April 23, 1972.

Shamsie, Yasmine. "Time For a "High-Road Approach to EPZ Development in Haiti." Paper presented at Conflict Prevention and Peace Forum (CPPF), Social Science Research Council, 5-7, Retrieved from http://www.ssrc.org/publications/view/03C92980-9E49-E011-9A1B001CC477EC84/.

Sheller, Mimi. "The Army of Sufferers: Peasant Democracy in Early Republic Haiti." New West Indian Guide 74, no. 1-2 (2000): 33-55.

Shen, Kona. "Touissaint-Louverture in Power, 1796-1801." History of Haiti, 1492-1805, Brown University Department of Africana Studies, http://library.brown.edu/haitihistory/8.html.

Shipler, David K. "U.S. Calls Haiti Voting 'Clouded' but Vows to Work With Winner," New York Times, January 20, 1988.

Simidor, Daniel. "25869: Simidor (Comment): Reuters Revisionism (Fwd)." Bob Corbett's Haiti List, http://www2.webster.edu/ corbetre/haiti-archivenew/msg26184.html.

Simons, Marlise. "Church in Haiti Launches Literacy Drive." New York Times, March 11, 1986.

"Situation Among Peasants in Northwest 'Uneasy,"' Port-au-Prince Radio Metropole [English Translation], April 19, 1988, Foreign Broadcast Information Service (FBIS) Daily Reports, April 21, 1988.

"Situation in Capital Provinces Updated," Port-au-Prince Radio Soleil Network [English Translate], June 21, 1988, Foreign Broadcast Information Service (FBIS) Daily Reports, Latin America, June 22, 1988.

Smarth, Luc. "Popular Organizations and the Transition to Democracy in Haiti" in Community Power and Grassroots Democracy: The Transformation of Social Life. London: Zed Books, 1997.

Smith, Ashley. "The New Occupation of Haiti: Aristide's Rise and Fall." International Socialist Review 35, (May-June 2004), http://isreview.org/issues/35/aristide.shtml. 
Smith, Matthew J. Red and Black in Haiti: Radicalism, Conflict, and Political Change, 1934-1957. Chapel Hill: University of North Carolina Press, 2009.

"Soldier Fatally Wounded Where Union Members Jailed," Bonaire Trans World Radio [English Translation], June 25, 1987, Foreign Broadcast Information Service (FBIS) Daily Reports, Latin America, June 26, 1987.

"Soldiers Break Up Cotes de Fer People's Court," Port-au-Prince Radio Soleil Network [English Translation], October 7, 1988, Foreign Broadcast Information Service (FBIS) Daily Reports, Latin America, October 11, 1988.

"Soldiers Call for Democracy," Paris AFP [English Translation], September 20, 1988, Foreign Broadcast Information Service (FBIS) Daily Reports, Latin America, September 21, 1988.

"Soldier Tells of Feelings About 'Higher-Ups,"' Port-au-Prince Radio Soleil Network [English Translation], September 19, 1988, Foreign Broadcast Information Service (FBIS) Daily Reports, Latin America, September 20, 1988.

Sontag. "Haitian Masses Find a 'Prophet.'” New York Times, 1990.

"Station Comments," Port-au-Prince Radio Soleil Network [English Translation], July 12, 1988, Foreign Broadcast Information Service (FBIS) Daily Reports, Latin America, July 13, 1988.

Steinberg, Paul F. "New Approaches to Causal Analysis in Policy Research." Paper Presented at the Annual Meeting of the American Political Science Association, Hilton Chicago and the Palmer House Hilton, Chicago, Illinois, September 2, 2004.

"Street Fires Set to Protest Military Government," Bridgetown CANA [English Translation], March 25, 1986, Foreign Broadcast Information Service (FBIS) Daily Reports, Latin America, March 26, 1986.

"Strike Called to Protest Voiding of Election Law," Bonaire Trans World Radio [English Translation], June 27, 1987, Foreign Broadcast Information Service (FBIS) Daily Reports, Latin America, June 29, 1987.

"Strikes, Demonstrations Bring Death, Clashes," Madrid EFE [English Translation], July 1, 1987, Foreign Broadcast Information Service (FBIS) Daily Reports, Latin America, July 1, 1987.

"Students, Women Hold Antigovernment Demonstrations," Port-au-Prince Domestic Service [English Translation], July 21, 1987, Foreign Broadcast Information Service (FBIS) Daily Reports, Latin America, July 23, 1987. 
"Supreme Court Judges Sworn in by Aristide," Port-au-Prince Radio Metropole [English Translation], March 18, 1991, Foreign Broadcast Information Service (FBIS) Daily Reports, Latin America, March 21, 1991.

Terry, Don. "Artful Career Officer: Prosper Avril," New York Times, September 19, 1988.

"The Charlemagne Perale Congress: APN Launches Anti-Occupation Campaign," This Week in Haiti 13, no. 11, June 7-13, 1995, http://www.hartfordhwp.com/archives/43a/083.html.

"'The Haitian Flag and Revolution': Papa Doc was Power Personified." The Palm Beach Post, April $23^{\text {rd }} 1971$.

"The Praslin Manifesto by Beaubrun Ardouin (1796-1865)." Island Lumminous, http://islandluminous.fiu.edu/part04-slide11.html.

"Thionier Revives Duvalierist REN Party," Buenos Aires Reuter [English Translation], October 31, 1986, Foreign Broadcast Information Service (FBIS) Daily Reports, Latin America, October 31, 1986.

Titus, Rubens François. Roadmap to Haiti's Next Revolution: A Plan for Diaspora Haitians to Contribute to a Peaceful Turnaround. iUniverse Com, 2012.

"TKL Organizes Collection to Aid Government," Port-au-Prince Radio Soleil Network [English Translation], March 25, 1991, Foreign Broadcast Information Service (FBIS) Daily Reports, Latin America, March 28, 1991.

"Top Duvalierist Among 10 Barred from Seeking Haiti's Presidency." New York Times, November 7, 1990.

"Trade Unions State Position on Situation," Port-au-Prince Domestic Service [English Translation], July 8, 1987, Foreign Broadcast Information Service (FBIS) Daily Reports, Latin America, July 9, 1987.

Treaster, Joseph B. "A Haitian Priest is Ousted by Order: Roman Catholic Group Expels Cleric Critical of Bishops' Panel and Government." New York Times, December $18,1988$.

- "A Paradox for Haiti's Presidency: Leslie Francois Manigat," New York Times, January 25, 1988.

- "Bestower of Silence and Despair: Henri Namphy," New York Times, June 21, 1988. 
- "Calls for End of Army Rule Grow in Haiti," New York Times, February 26, 1989.

- "Haiti About-Face: General 'Looking Like Dictator,"' New York Times, January 25, 1990.

- "Haitians Fear Violence After Colonel's Ouster," New York Times, October 2, 1988.

- $\quad$ "Haitians See Financial Crisis and Plead for Aid," New York Times, September 24, 1988.

- $\quad$ "Haitian Struggles to Consolidate Power," New York Times, September 22, 1988.

- "Haitians Warily Enter an Uncertain New Era," New York Times, Feb 7, 1988.

- $\quad$ "Haiti Deports Some Opposition Leaders." New York Times, January 22, 1990.

- "Haiti's New Chief Fostering Doubts," New York Times, December 6, 1988.

- "Haiti's President Rejects Military Order," New York Times, June 16, 1988.

- "Haiti's Ruler Says He'll Lift State of Siege on Tuesday." New York Times, January 1990.

- "Many in Haiti Wonder Who is Really in Charge," New York Times, September $25,1988$.

- "New Haitian Regime Reportedly Jails 16 Foes," New York Times, June 23, 1988

- $\quad$ "New Haiti Chiefs Charm 3 Backers of Democracy," New York Times, September 28, 1988.

- $\quad$ "Rebellious Troops in Haiti Say They are Ready to Negotiate." New York Times, April 10, 1989.

- $\quad$ "Strike and Boycott Are Urged in Haiti," New York Times, January 15, 1988.

- "The General and the Sergeant: Confreres in Haiti," New York Times, October 3, 1988.

- "U.S. Mellowing Toward Haiti, Releases Some Aid," New York Times, November 20, 1988. 
Trouillot, Michel-Rolph. Haiti, State Against Nation: The Origins and Legacy of Duvalierism. New York: Monthly Review Press, 1990.

- "Haiti's Nightmare and the Lessons of History, 1994" in A Haiti Anthology: Libète. Princeton, NJ: Markus Wiener Publishers, 1999.

- "The Inconvenience of Freedom: Free People of Color and the Political Aftermath of Slavery in Dominica and Saint-Domingue/Haiti," in The Meaning of Freedom: Economics, Politics, and Culture after Slavery. Pittsburgh: University of Pittsburgh Press, 1992.

"'Turbulent' Situation Reported in Delmas Area," Port-au-Prince Radio Soleil Network [English Translation], April 14, 1988, Foreign Broadcast Information Service (FBIS) Daily Reports, Latin America, April 15, 1988.

"Unions Address Minister on Rights Violations," Port-au-Prince Radio Soleil Network [English Translation], April 26, 1988, Foreign Broadcast Information Service (FBIS) Daily Reports, Latin America, April 28, 1988.

"Union Federations Call for Changes in Government," Port-au-Prince Radio Soleil Network [English Translation], March 15, 1990, Foreign Broadcast Information Service (FBIS) Daily Reports, Latin America, March 20, 1990.

"Union Leader on Divisiveness, Electioneering," Port-au-Prince Radio Soleil Network [English Translation], February 8, 1990, Foreign Broadcast Information Service (FBIS) Daily Reports, Latin America, February 12, 1990.

United States, Agency for International Development. Urban Health and Community Development-Phase II. Project Paper (May 1984), retrieved from http://pdf.usaid.gov/pdf_docs/PDAAT248.pdf.

"U.S. Ambassador's Meeting Canceled," Port-au-Prince Radio Metropole [English Translation], November 28, 1989, Foreign Broadcast Information Service (FBIS) Daily Reports, Latin America, November 30, 1989.

"Violence Begins After Manigat Warns Duvalierists," Bonaire Trans World Radio [English Translation], April 29, 1988, Foreign Broadcast Information Service (FBIS) Daily Reports, Latin America, May 2, 1988.

"Violence, Looting Reported; Cabinet Appointed," Madrid EFE [English Translation], February 8, 1986, Foreign Broadcast Information Service (FBIS) Daily Reports, Latin America, February 10, 1986.

Volman, Dennis. "'Revolutionary Process' Has Begun in Haiti, Says Prominent Former Exile." Christian Science Monitor, February 21, 1986. 
Wesolowski, Zdzislaw P. "The Polish Contribution to the Haitian War of Independence," Toussaint Louverture Historical Society (blog), http://toussaintlouverturehs.org/PolishContribut.htm.

Wolin, Sheldon S. "Fugitive Democracy," in Democracy and Difference: Contesting the Boundaries of the Political. Princeton, N.J.: Princeton University Press, 1996.

"Womens' Group Reacts," Port-au-Prince Radio Soleil Network [English Translation], May 12, 1988, Foreign Broadcast Information Service (FBIS) Daily Reports, Latin America, May 16, 1988.

"Workers Organization Holds Anniversary Rally," Port-au-Prince Radio Soleil Network [English Translation], May 16, 1988, Foreign Broadcast Information Service (FBIS) Daily Reports, Latin America, May 19, 1988.

"Youth Groups Demonstrate Support for Aristide," Port-au-Prince Radio Metropole [English Translation], March 25, 1991, Foreign Broadcast Information Service (FBIS) Daily Reports, Latin America, March 28, 1991.

"Young Lands in Haiti on 9th Stop of Tour: To Stress Human Rights Concern-May Also Discuss More Aid.” New York Times, August 15, 1977.

Zakaria, Fareed. "The Reagan Strategy of Containment." Political Science Quarterly 105, no. 3 (Autumn 1990): 373-395.

"1 Dead, 4 Wounded," Bonaire Trans World Radio [English Translation], June 30, 1987, Foreign Broadcast Information Service (FBIS) Daily Reports, Latin America, July $1,1987$.

"1st Anniversary of Freycinau 'Ambush' Marked," Port-au-Prince Radio Soleil Network [English Translation], August 24, 1988, Foreign Broadcast Information Service (FBIS) Daily Reports, Latin America, August 26, 1988.

"5 Dead, 70 Injured 11 Sep," Paris AFP [English Translation], September 12, 1988, Foreign Broadcast Information Service (FBIS) Daily Reports, Latin America, September 12, 1988.

"6 Jul Strike Called," Paris AFP [English Translation], July 5, 1987, Foreign Broadcast Information Service (FBIS) Daily Reports, Latin America, July 6, 1987.

"7 Killed As Police Break Up Demonstration," Madrid EFE [English Translation], April 26, 1986, Foreign Broadcast Information Service (FBIS) Daily Reports, Latin America, April 28, 1986. 
"10 Youths Reportedly Killed in Artibonite," Port-au-Prince Radio Soleil Network [English Translation], August 16, 1988, Foreign Broadcast Information Service (FBIS) Daily Reports, Latin America, August 17, 1988.

"33 Organizations Form 'Pressure Group,"' Port-au-Prince Radio Nationale [English Translation], October 5, 1989, Foreign Broadcast Information Service (FBIS) Daily Reports, Latin America, October 12, 1989. 


\section{DIMMY HERARD}

Born, Miami, Florida

2001-2005

B.A., Political Science

Hanover College

Hanover, Indiana

$2006-2016$

Doctoral Candidate

Department of Politics and International Relations

Florida International University

Miami, Florida

$2006-2010$

$2010-2015$

$2013-2015$

Teaching Assistant

Department of Politics and International Relations

Florida International University

Miami, Florida

Research Assistant

Disaster Risk Reduction in the Americas Program

Florida International University

Miami, Florida

Graduate Student Archivist

Bernard Diederich Collection

Special Collections \& University Archives

Florida International University

$2014-2015$

Program Assistant

Digital Library of the Caribbean (dLOC)

Florida International University

Miami, Florida

$2014-2016$

Instructor, Politics of Latin America, and International

Relations

Department of Politics and International Relations

Florida International University

Miami, Florida 


\section{PUBLICATIONS AND PRESENTATIONS}

Sarmiento, J.P., Gelman, P., Herard, D., \& Bittner, P. (Eds.), "Urban Disaster Risk: Systematization of Neighborhood Practices," Disaster Risk Reduction and Resilience Series, United States Agency of International Development, Florida International University, Extreme Events Institute, In Progress.

Herard, Dimmy. "Restraining Democracy: Haiti in the Post-Duvalier Period." Paper presented at the Caribbean Studies Association Annual Conference, Port-au-Prince, Haiti, June 2016.

Herard, Dimmy. "Democracy and the Disciplining of Haiti's Laboring Masses." Paper presented at the ASWAD 8th Biennial Conference, Charleston, South Carolina, November 2015.

Sarmiento, Juan Pablo, Herard, Dimmy. "Sistematización in Urban Disaster Risk Reduction." International Journal of Disaster Prevention and Management 24, no. 2 (2015): 221-229.

Herard, Dimmy "Disaster and the Co-opting of the Democratic Imperative," Paper presented at the Florida Education Fund's McKnight Mid-Year Research and Writing Conference, Tampa, Florida, February 2015.

Sarmiento, Juan Pablo, Hoberman, Gabriela, and Dimmy Herard. "The Challenges of Urban Disaster Risk Reduction in Informal Settlements." Paper presented at the 45th Urban Affairs Association Conference, Miami, Florida, April 2015.

Herard, Dimmy. "The Debate over Aristide's Presidency and Ouster," An Island Luminous, Digital Library of the Caribbean (dLOC), 2013, http://islandluminous.fiu.edu/learn.html.

Herard, Dimmy. "Lavalas and the Haitian Tradition of Mass Mobilization," Paper presented at the Ethnologie Haitienne et Ethnologie d'Haiti: Histoire et Mémoires d'une Discipline, Journée d'Etude, Faculte d'Ethnologie de Université d'État d'Haiti (UEH), Port-au-Prince, Haiti, November 2013.

Herard, Dimmy. "Haiti in the Third Wave: Haitian Civil Society, the Emergence of Lavalas, and Disaster." Paper Presented at the Twenty-Fourth Annual Haitian Studies Association (HSA) Conference, York College-City University of New York (CUNY), Jamaica, New York, November 2012. 